\title{
Suitability of Ponds Formed by Strip Mining in Eastern Oklahoma for Public Water Supply, Aquatic Life, Waterfowl Habitat, Livestock Watering, Irrigation, and Recreation
}

By Renee S. Parkhurst

Prepared in cooperation with the Okiahoma Geological Survey 


\title{
U.S. DEPARTMENT OF THE INTERIOR BRUCE BABBITT, Secretary
}

\author{
U.S. GEOLOGICAL SURVEY \\ GORDON P. EATON, Director
}

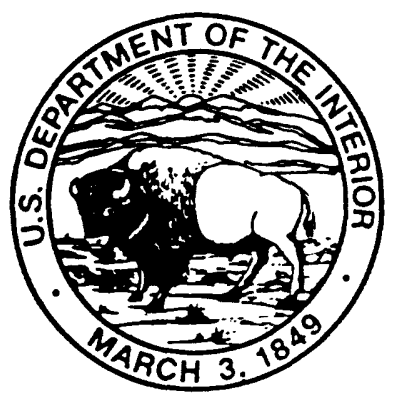

Any use of trade names in this publication is for descriptive purposes only and does not Imply endorsement by the U.S. Government.

For additional information write to:

Distrlct Chief

U.S. Geological Survey 202 NW 66th Street, Bldg. 7 Oklahoma Clty, Oklahoma 73116
Coples of this report can be purchased from: U.S. Geological Survey Earth Science Information Center Open-Flle Reports Sectlon Box 25286, MS 517 Denver, Colorado 80225 


\section{CONTENTS}

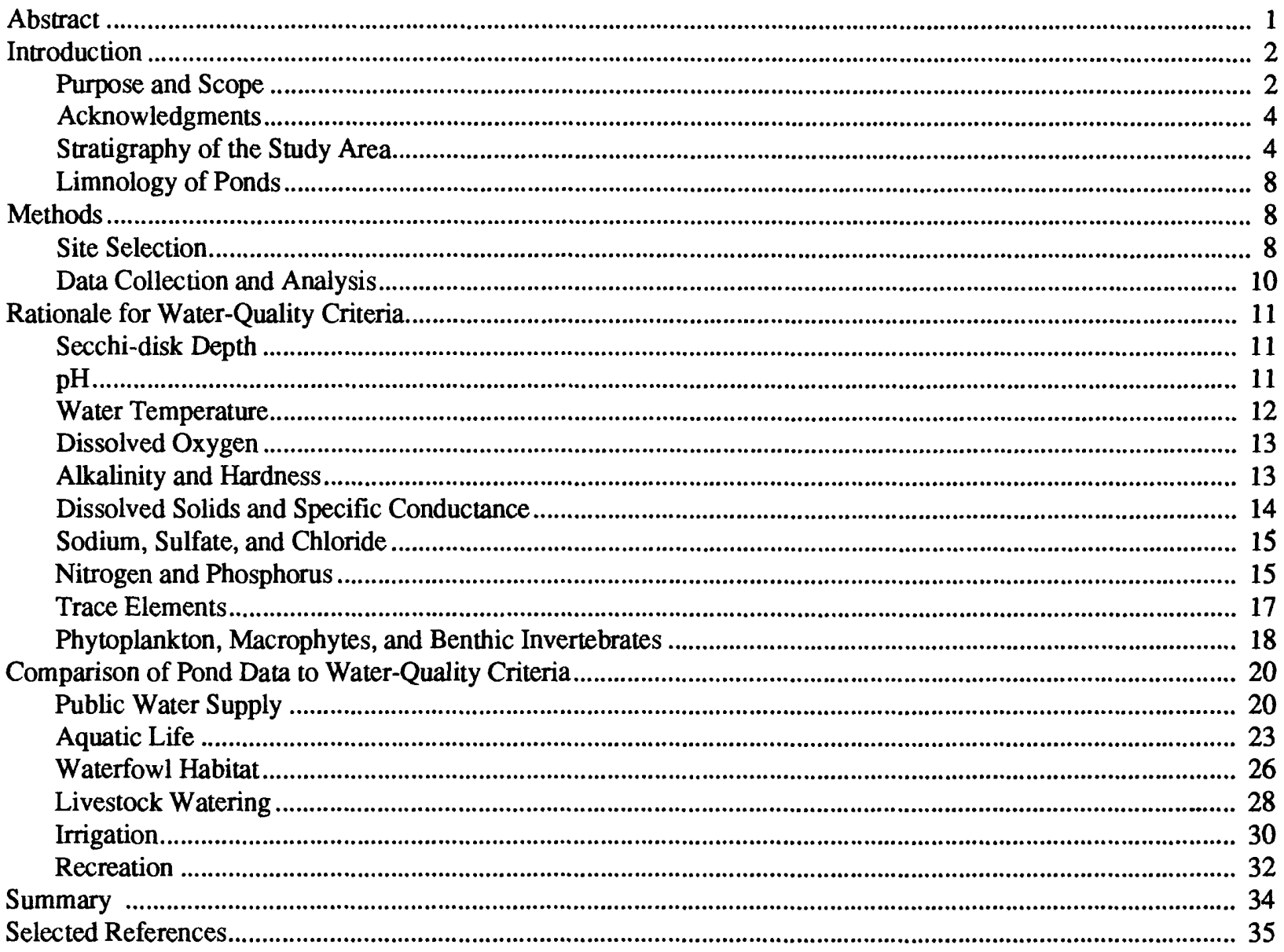

\section{FIGURES}

1. Index map showing the Oklahoma part of the Western Region of the Interior Coal Province, study area, and study ponds

2. Map showing locations of coal fields of the contiguous United States........................................................ 5

3. Map showing location of coal areas in Oklahoma, coal-mine ponds, and control ponds.................................. 6

4. Generalized geologic column showing sequence of coal beds of Desmoinesian age in Oklahoma................... 7

5. Generalized illustration of a pond and its limnologic zones. .......................................................................

\section{TABLES}

1. Concentrations of chlorophyll A, B, and $\mathrm{C}$ in water samples from study ponds ........................................... 38

2. Values for maximum weekly average temperatures for growth and short-term maximum temperature for survival of juvenile and adult fish species, in degrees Celsius ............................................................. 12

3. Values for maximum weekly average temperatures for spawning and short-term maximum temperature

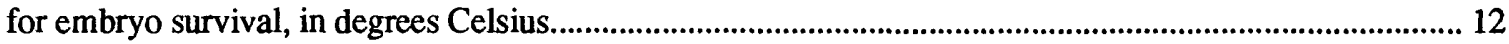

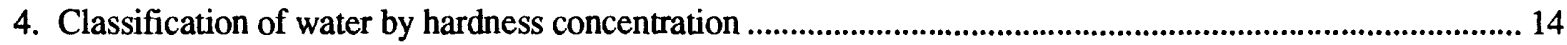

5. Maximum concentration of dissolved solids recommended for various livestock........................................ 15

6. Suitability of water for irrigation based on dissolved-solids concentrations in arid and semiarid regions..... 15 
7. Maximum total ammonia concentrations recommended for the protection of aquatic life, in milligrams per liter

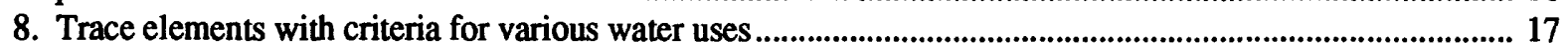

9. Water-quality criteria and standards for public water supply ................................................................. 19

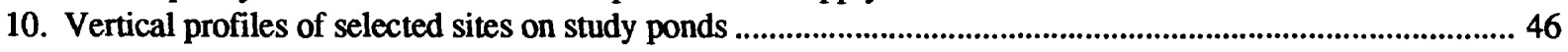

11. Comparison of pond-water quality to water-quality criteria for public water supply................................... 21

12. Concentrations of major dissolved chemical constituents and selected physical constituents for samples from study ponds.

13. Concentrations of selected plant nutrients in water samples from study ponds.............................................. 84

14. Concentrations of trace elements in water samples from study ponds........................................................ 88

15. Water-quality criteria for the protection of aquatic life ......................................................................... 23

16. Water-quality criteria for the protection of aquatic life that are dependent on hardness ............................... 24

17. Comparison of pond-water quality to water-quality criteria for the protection of aquatic life ......................... 25

18. Taxa and concentrations of phytoplankton in water samples from study ponds.............................................108

19. Taxa and concentrations of benthic invertebrates in samples from study ponds ...........................................162

20. Water-quality criteria for the protection of waterfowl ................................................................................... 26

21. Comparison of pond-water quality to water-quality criteria for the protection of waterfowl........................ 27

22. Water-quality criteria for the protection of livestock....................................................................................... 28

23. Comparison of pond-water quality to water-quality criteria for the protection of livestock ......................... 29

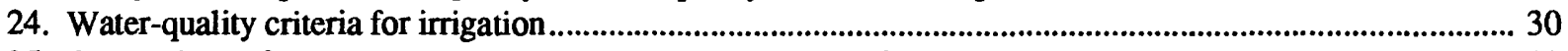

25. Comparison of pond-water quality to water-quality criteria for irrigation ..................................................... 32

26. Water-quality criteria for recreation................................................................................................................... 33

27. Comparison of pond-water quality to water-quality criteria for recreation ...................................................33

28. Comparison of the number of ponds with samples exceeding one or more water-quality criteria for each water use

\section{CONVERSION FACTORS AND ABBREVIATED WATER-QUALITY UNITS}

\begin{tabular}{rll}
\hline Multiply & By & To obtain \\
\hline inch (in.) & 2.53807 & centimeter \\
foot (ft) & 0.3048 & meter \\
mile $(\mathrm{mi})$ & 1.609 & kilometer \\
square mile $\left(\mathrm{mi}^{2}\right)$ & 2.590 & square kilometer \\
acre & 0.4047 & hectare \\
ounce & 29.5858 & milliliter \\
acre-feet (acre-ft) & 1233 & cubic meters \\
\hline
\end{tabular}

Temperature in degrees Fahrenheit $\left({ }^{\circ} \mathrm{F}\right)$ may be converted to degrees Celsius $\left({ }^{\circ} \mathrm{C}\right)$ as follows:

$$
{ }^{\circ} \mathrm{C}=5 / 9\left({ }^{\circ} \mathrm{F}-32\right)
$$

The following terms and abbreviations also are used in this report:

$$
\begin{aligned}
\text { microsiemens per centimeter } & (\mu \mathrm{S} / \mathrm{cm}) \\
\text { milliequivalents per liter } & (\mathrm{meq} / \mathrm{L}) \\
\text { milligrams per liter } & (\mathrm{mg} / \mathrm{L}) \\
\text { micrograms per liter } & (\mu \mathrm{g} / \mathrm{L}) \\
\text { micrometer } & (\mu \mathrm{m})
\end{aligned}
$$




\section{SUITABILITY OF PONDS FORMED BY STRIP MINING IN EASTERN OKLAHOMA FOR PUBLIC WATER SUPPLY, AQUATIC LIFE, WATERFOWL HABITAT, LIVESTOCK WATERING, IRRIGATION, AND RECREATION}

\section{By Renee S. Parkhurst}

\section{Abstract}

A study of coal ponds formed by strip mining in eastern Oklahoma included 25 ponds formed by strip mining from the Croweburg, McAlester, and Iron Post coal seams and 6 noncoal-mine ponds in the coal-mining area. Waterquality samples were collected in the spring and summer of 1985 to determine the suitability of the ponds for public water supply, aquatic life, waterfowl habitat, livestock watering, irrigation, and recreation. The rationale for water-quality criteria and the criteria used for each proposed use are discussed. The ponds were grouped by the coal seam mined or as non-coal-mine ponds, and the number of ponds from each group containing water that exceeded a given criterion is noted.

Water in many of the ponds can be used for public water supplies if other sources are not available. Water in most of these ponds exceeds one or more secondary standards, but meets all primary standards. Water samples from the epilimnion (shallow strata as determined by temperature) of six ponds exceeded one or more primary standards, which are criteria protective of human health. Water samples from five of eight Iron Post ponds exceeded the selenium criterion. Water samples from all 31 ponds exceeded one or more secondary standards, which are criteria for the protection of human welfare. The criteria most often exceeded were iron, manganese, dissolved solids, and sulfate, which are secondary standards. The criteria for iron and manganese were exceeded more frequently in the non-coal-mine ponds, whereas ponds formed by strip mining were more likely to exceed the criteria for dissolved solids and sulfate.

The ponds are marginally suited for aquatic life. Water samples from the epilimnion of 18 ponds exceeded criteria protective of aquatic life. The criteria for mercury and iron were exceeded most often. Little difference was detected between mine ponds and non-coal-mine ponds. Dissolved oxygen concentrations in the hypolimnion (deepest strata) of all the ponds were less than the minimum criterion during the summer. This decreases available fish habitat and affects the type and number of benthic invertebrates.

The ponds are generally well suited for use by wintering and migrating waterfowl. Thirteen of the ponds contained water that exceeded the $\mathrm{pH}$, alkalinity, and selenium criteria. The non-coalmine ponds had the largest percentage of ponds exceeding $\mathrm{pH}$ and alkalinity criteria. Water samples from five of eight Iron Post ponds exceeded the selenium criterion. All ponds are generally unsuitable as waterfowl habitat during the summer because of high temperatures and low dissolved oxygen.

Most of the ponds are well suited for livestock watering. Water samples from the epilimnion of 29 ponds met all chemical and physical criteria. Water samples from five ponds exceeded the criteria in the hypolimnion. Mine ponds exceeded chemical and physical criteria more often than non-coal-mine ponds. All the ponds contained phytoplankton species potentially toxic to livestock.

Water from most of the ponds is marginally suitable for irrigation of sensitive crops, but is more suitable for irrigation of semitolerant and tol- 
erant crops. Most major cash crops grown in eastern Oklahoma are semitolerant and tolerant crops. Water from the epilimnion of 14 ponds was suitable for irrigation under almost all conditions. Water from the epilimnion of 20 ponds was suitable for irrigation of semitolerant crops, and water from the epilimnion of 25 ponds is suitable for irrigation of tolerant crops. The dissolved solids criterion was exceeded the most often.

Most of the ponds would not be suitable for swimming. The $\mathrm{pH}$ criterion was exceeded in 17 ponds and turbidity restricts visibility needed for diving in 23 ponds. Little difference was detected between mine ponds and non-coal-mine ponds. Many of the ponds formed by strip mining have steep banks that may be dangerous to swimmers.

\section{INTRODUCTION}

The objectives of this study are (1) to describe the limnological characteristics of ponds formed by strip mining and other ponds not associated with mining and (2) to develop an understanding of hydrologic, chemical, and biological processes occurring within the ponds and interrelationships between the ponds. Ponds were selected to determine if the characteristics are significantly different between ponds from different coal seams.

Identified coal resources are present in an area of approximately $8,000 \mathrm{mi}^{2}$ in eastern Oklahoma (fig. 1). Mining began in 1872 and early production was from underground mines. Strip mining became more advantageous with the development of large power equipment (Johnson, 1974). By 1944, 50 percent of annual production was from strip mines, and by 1964 strip mines produced 99 percent of Oklahoma's coal. In 1986, 2,969,523 tons of coal were produced from surface mines compared to 6,751 tons of coal produced from underground mines, with 7.9 billion short tons of coal remaining (Oklahoma Department of Mines, 1987).

Ponds formed by strip mining occupy an estimated area of 5,400 acres (Marcher and others, 1984 and 1987) and with an estimated average depth of $17 \mathrm{ft}$, the total amount of water stored in the ponds is approximately 91,800 acre-ft. A few of the ponds are used for public water supplies, stock watering, irrigation, and recreation, and many provide habitat for aquatic life.
A surface-mining operation involves digging a long, open trench through the overburden to expose and remove the coal. As each succeeding parallel cut is made, the overburden is placed as spoil material into the cut previously excavated. Successive cuts are mined until the overburden thickness becomes so great that the coal can no longer be mined economically. The final cut leaves an open trench bounded by the last spoil bank on one side and the highwall on the other. This trench may fill with water from precipitation, surfacewater inflow, and ground-water seepage, and forms a last-cut pond. These ponds are generally long, narrow, and deep. Many of the last-cut ponds have arms or inlets created by inclined haul roads. These arms of a last-cut pond are shallow at one end and become deeper toward the main pond.

Prior to passage of Oklahoma's Open Cut Land Reclamation Act (effective January 1, 1968) and Mining Lands Reclamation Act of June 1971, most mined lands were left looking like a large washboard. Between 1968 and 1977 land strip-mined for coal was left partially reclaimed. The Surface Mining Control and Reclamation Act was signed into law in August, 1977. In areas strip mined after August 1977, ridges of spoil are graded, topsoil is replaced, the area is revegetated and high walls are graded. Some areas mined after August 1977 were not reclaimed because of financial and legal difficulties.

This trench may fill with water from precipitation, surface-water inflow, and ground-water seepage, and forms a last-cut pond. These ponds are generally long, narrow, and deep. Many of the last-cut ponds have arms or inlets created by inclined haul roads. These arms of a last-cut pond are shallow at one end and become deeper toward the main pond. Prior to passage of Oklahoma's Open Cut Land Reclamation Act (e in August, 1977. In areas strip mined after August 1977 , ridges of spoil are graded, topsoil is replaced, the area is revegetated and high walls are graded. Some areas mined after August 1977 were not reclaimed because of financial and legal difficulties.

\section{Purpose and Scope}

This report describes the limnological characteristics of the ponds formed by strip mining and compares concentrations of selected inorganic constituents, nutrients, and biological species with water-quality criteria for public water supply, aquatic life, waterfowl habitat, livestock watering, irrigation, and recreation. Because often the usefulness of a pond is relative, other nearby ponds not associated with mining were also sampled. Many dissolved or suspended substances in 


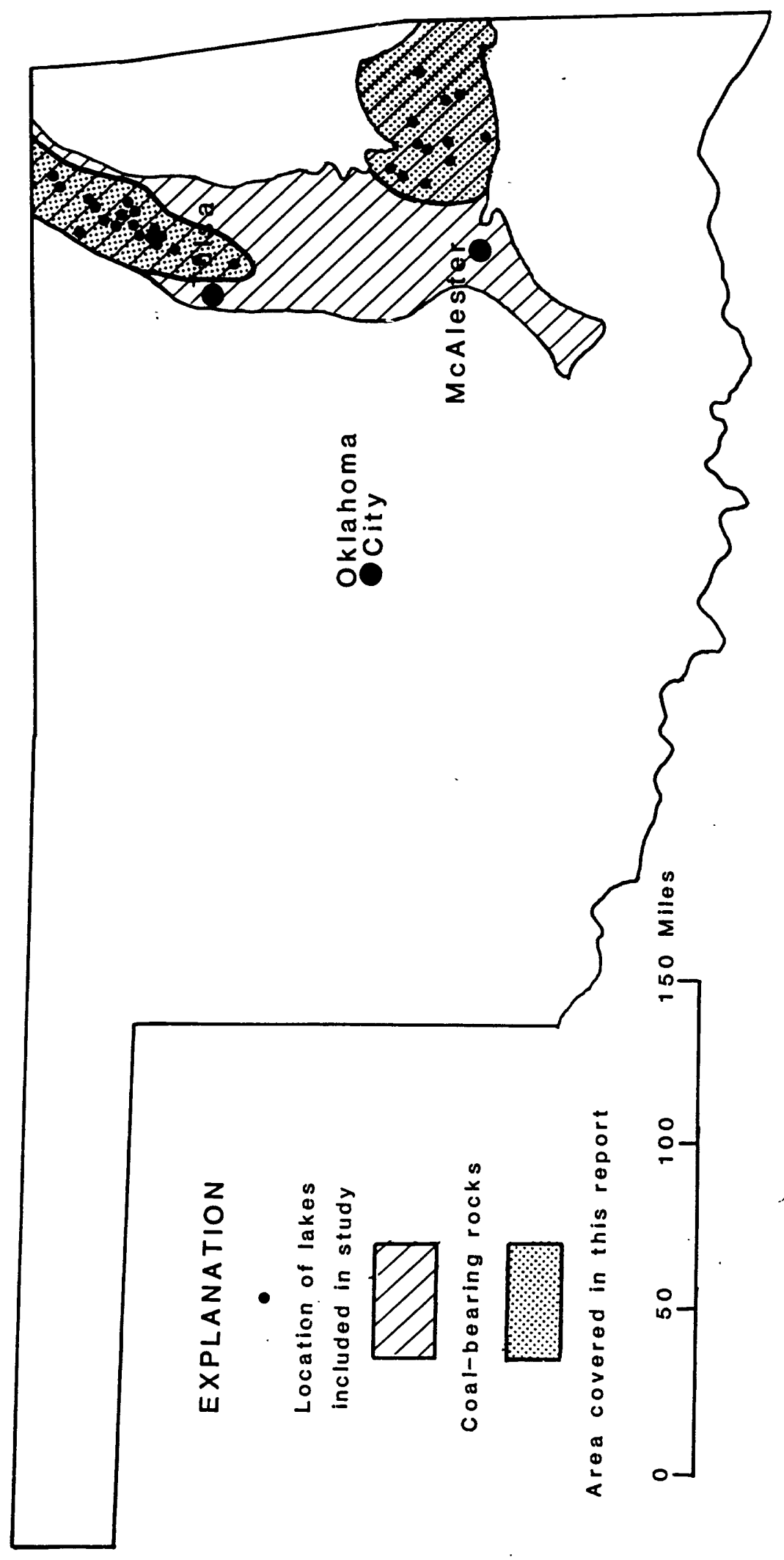

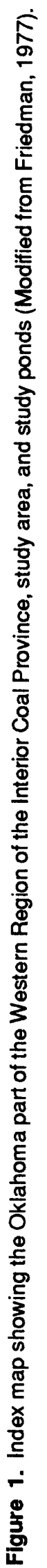


water may be detrimental to a particular use. These substances include some inorganic elements and compounds, certain man-made organic compounds, pathogenic and parasitic organisms, herbicide and pesticide residues, some biologically produced toxins, and radionuclides (National Academy of Sciences and National Academy of Engineering, 1973). This study reports on the constituents that are related to the construction of the pond and not those constituents that may have been caused by other human activities.

The U.S. Geological Survey, in cooperation with the Oklahoma Geological Survey, collected water-quality data from 25 ponds associated with strip mining and 6 ponds from the same area that were not associated with strip mining. The ponds formed by strip mining will be referred to by the name of the coal seam from which the majority of the coal was mined. The ponds are located in northeast and east-central Oklahoma (fig. 1). Water-quality data were collected in the spring and summer of 1985 . Twenty-three of the ponds formed by strip mining are last-cut ponds. Ten of these have highwalls and spoil ridges, six have highwalls with graded spoil, and seven have no highwall or spoil ridges. The remaining two ponds formed by strip mining are catchment-basin ponds or sedimentation ponds, created to catch runoff. These tend to be smaller and shallower, and look more like farm ponds. Both ponds were created on or near land mined for Iron Post coal.

The six ponds which were not created by strip mining are used as an experimental control, and will be referred to as control ponds. The control ponds include a limestone quarry, a sandstone quarry, an excavated farm pond with no inlet or outlet, and three farm ponds with spillways. The area near the spillways in the farm ponds was deepened by excavation and the opposite ends have intermittent streams as inlets. All six control ponds vary in shape and size.

\section{Acknowiedgments}

The author wishes to express her appreciation to the landowners and coal companies for allowing access to ponds. The University of Iowa Hygienics Lab analyzed samples for chlorophyll, phytoplankton, and benthic invertebrates. Stephen Weber and the Oklahoma Geological Survey analytical-chemistry staff performed the laboratory analyses of the major ions and trace elements included in this report. Michael Johnson of Ducks Unlimited and formerly of the U.S. Fish and Wildlife service gave advice on the sections pertaining to waterfowl.

\section{Stratigraphy of the Study Area}

The bituminous coal deposits of eastern Oklaho$\mathrm{ma}$ are in the southern part of the Western Interior Coal Basin (Averitt, 1975) (fig. 2). The coals in east-central Oklahoma are in an eroded structural and depositional basin called the Arkoma Basin (fig. 3). The basin contains the upper and lower Hartshorne, upper and lower McAlester (Stigler), upper and lower Cavanal, Lower Witteville, and Secor coals, all of Middle Pennsylvanian age. The northeastern part of the coal field is a depositional shelf referred to as the Northeast Oklahoma Shelf and contains more limestone than the coalbearing rocks of the Arkoma basin. The shelf contains the Rowe, Drywood, Secor, Blue Jacket, Weir-Pittsburg, Mineral, Fleming, Croweburg, Bevier, and Iron Post coals of Middle Pennsylvanian age, and the Lexington, Jenks, and Dawson coals of Middle and Late Pennsylvanian age. Most of the shelf coals are suitable as fuel for electricity generation, and many of the coals of the basin area are suitable for coke manufacture (Friedman, 1974). The strip-mine ponds included in this study are associated with the Croweburg, Iron Post, and McAlester (Stigler) coal seams. Locations of the strip-mine pond and the control ponds are shown in figure 3. A generalized geologic column showing stratigraphic position of the coal seams is shown in figure 4.

The Croweburg coal, in the Northeast Oklahoma Shelf, has the lowest sulfur content of any coal in the shelf area, with 0.4 to 3.5 percent sulfur, averaging 1.9 percent. The coal seam is 0.2 to 3.4 feet thick. The 40 to 75 feet overburden consists of a thin black shale, a thick gray shale, a thick limestone and shale unit, and in some areas a sandstone unit (Friedman, 1974). The ponds created by mining Croweburg coal are referred to as Croweburg ponds 1 through 8 .

The Iron Post coal is found mostly on hilltops in northeast Oklahoma and is 0.3 to 1.4 feet thick. The sulfur content is 3.5 to 5.0 percent, averaging 4.0 percent. The overburden consists of shale that contains pyrite and hard nodules, dense limestone, and dark gray shale. Because of the dense overburden, explosives are used in the mining process. The many limestone boulders created by blasting make reclamation difficult (Friedman, 1974). The ponds created by mining Iron Post coal are referred to as Iron Post ponds 1 through 8.

The McAlester (Stigler) coal is located in the Arkoma Basin and in some places is split into two separate coal beds (Friedman, 1978). The coal seam is from 0.1 to 5.0 feet thick. It contains 0.4 to 5.2 percent sulfur and averages 1.5 percent. The overburden consists of marine clay shales and lenticular sandstones (Karvelot, 1973). Contour mining is practiced in this area, therefore, the mined areas tend to be long and 


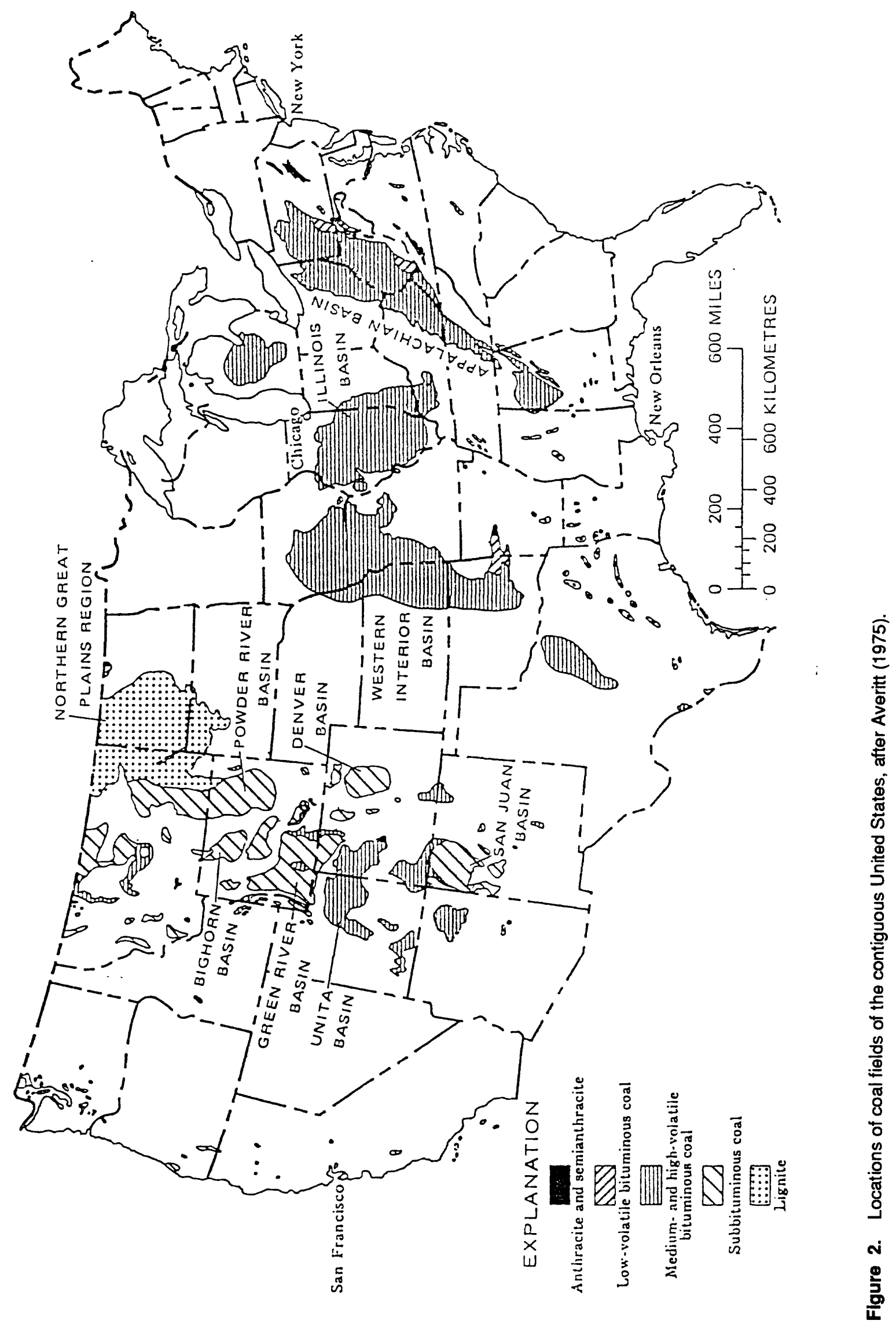




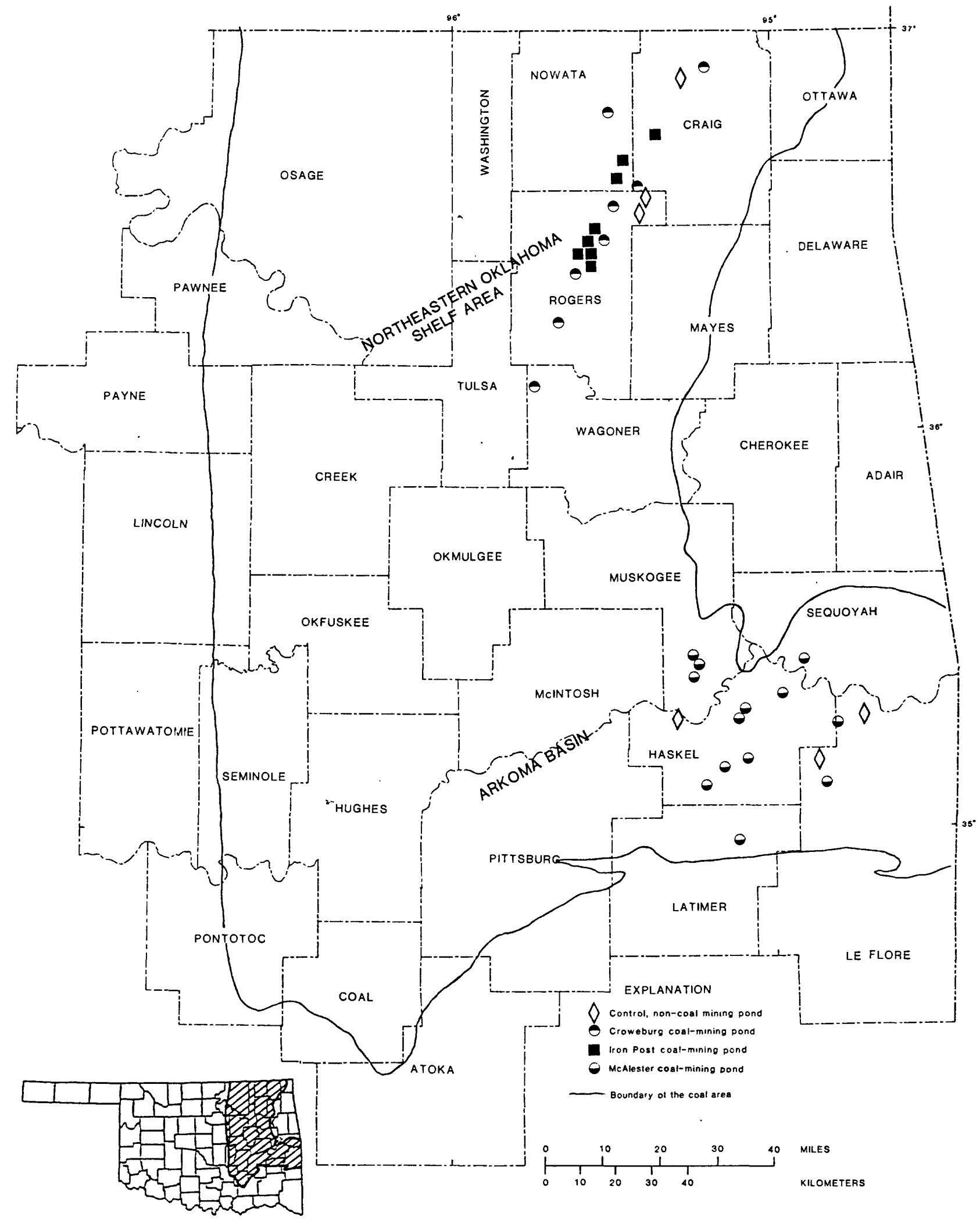

Figure 3. Location of coal areas in Oklahoma, coal-mine ponds, and control ponds. 


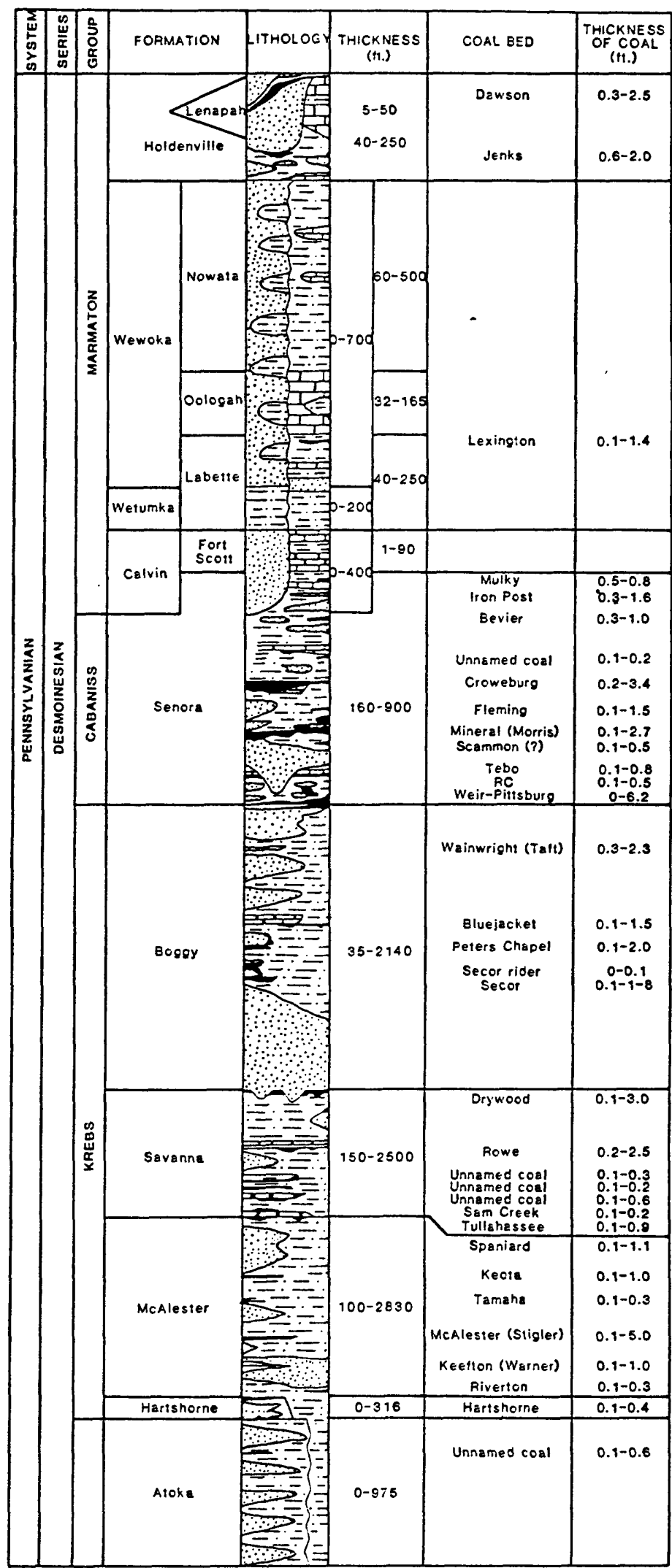

EXPLANATION

SANDSTONE

SHALE

臣 LIMESTONE

COAL

Figure 4. Generalized geologic column showing sequence of coal beds of Desmoinesian age in Oklahoma (Modified from Friedman, 1974, and Hemish, 1987). 
thin. The ponds created by mining for McAlester (Stigler) coal are referred to as McAlester ponds 1 through 9.

\section{Limnology of Ponds}

Limnology is the study of lakes, streams, and ponds. Limnology has specialized terminology. Terms used in this report are defined below. Ponds and lakes have a number of zones or regions, each with its own physical and biological characteristics. The zones are defined by light penetration and temperature. Both the open water area and the bottom of the pond have regions with different characteristics. The areal extent of the different zones and the ratio of the area of one type of zone to the area of another may affect the biological and chemical characteristics of a pond.

The upper part of the pond where light penetrates is called the euphotic or photic zone (fig. 5). Photosynthesis occurs in this zone and the majority of the plankton live here. Below the euphotic zone is the aphotic zone where light cannot penetrate. Some shallow ponds do not have an aphotic zone (Goldman and Horne, 1983).

Ponds that thermally stratify or layer are subdivided into zones defined by temperature and dissolvedoxygen content. The upper zone is called the epilimnion, and is characterized by warm temperatures and large dissolved-oxygen content. Most of the plankton in a pond are within the epilimnion. This zone is subject to mixing by winds and is within the photic zone. Below this is a thin zone called the metalimnion or thermocline where temperature and dissolved oxygen decreases abruptly. It is often a barrier for wind mixing and for free-floating plankton. The deepest zone is the hypolimnion. Light cannot penetrate this zone and, because of the thermocline, the water does not mix with water from the upper zones. Therefore, the temperature is much lower and the oxygen content becomes depleted (Goldman and Home, 1983). Ponds in Oklahoma that stratify tend to be monomictic; that is, they mix or turn over in the fall and remain mixed until the spring when warm weather causes stratification.

The bottom of a pond is called the benthic region. This region often has three distinct zones, the littoral, sublittoral, and profundal. The littoral zone extends from the shore to a depth where the light is barely sufficient for rooted aquatic plants to grow. The biologic community in this zone tends to have a higher diversity and higher annual production than the other benthic zones. The sublittoral zone is the zone beyond the littoral zone. It lacks rooted plants, but still is well oxygenated. The biologic community is less diverse because the available habitat is less diverse. The zone where light does not reach is the profundal zone. The temperature is nearly constant and under certain circumstances the dissolved oxygen content becomes depleted and methane and carbon dioxide are abundant. The sediments are usually fine and the biologic community is less abundant and less diverse (Cole, 1975).

Productivity is a term often used in limnology and refers to the sum total of energy-trapping processes, comprising all the photosynthetic and chemosynthetic processes in the system (Reid and Wood, 1976). There are several indices of productivity, including rooted submerged vegetation, plankton, benthic fauna, organic content, chlorophyll content (Welch, 1952), and oxygen deficit (Cole, 1975).

Organisms living in a pond also have specialized terms. The term plankton refers to all microscopic floating or swimming organisms. Phytoplankton are floating plants better known as algae. The zooplankton are floating invertebrates. Zooplankton are much more motile than the phytoplankton and graze on phytoplankton or other zooplankton. Animals living on the bottom or in the bottom sediments are benthos or, more specifically, benthic invertebrates.

\section{METHODS}

\section{Site Selection}

The ponds formed by strip mining were selected to be representative of ponds formed by strip mining in Oklahoma. To meet the objective of comparing ponds from different coal seams, ponds from three coal seams were selected to be representative of ponds formed by strip mining from all the coal seams in Oklahoma.

Coal seams with the largest amount of area mined were used. The ponds formed by strip mining were chosen using a stratified random selection method. All known ponds from the three coal seams were identified using maps by Johnson (1974) and Friedman (1982). The ponds were numbered and a random numbers table was used to select six ponds from each coal seam. Field reconnaissance was conducted and if the pond selected was found to be inaccessible, or to be unsuitable because of draining, dumping of garbage, or influence from a nearby stream, the nearest suitable pond was used.

The 18 ponds selected by the above method were all excavated before 1972 . To incorporate newly excavated ponds into the study a different method of selection was used. Two recently excavated ponds 


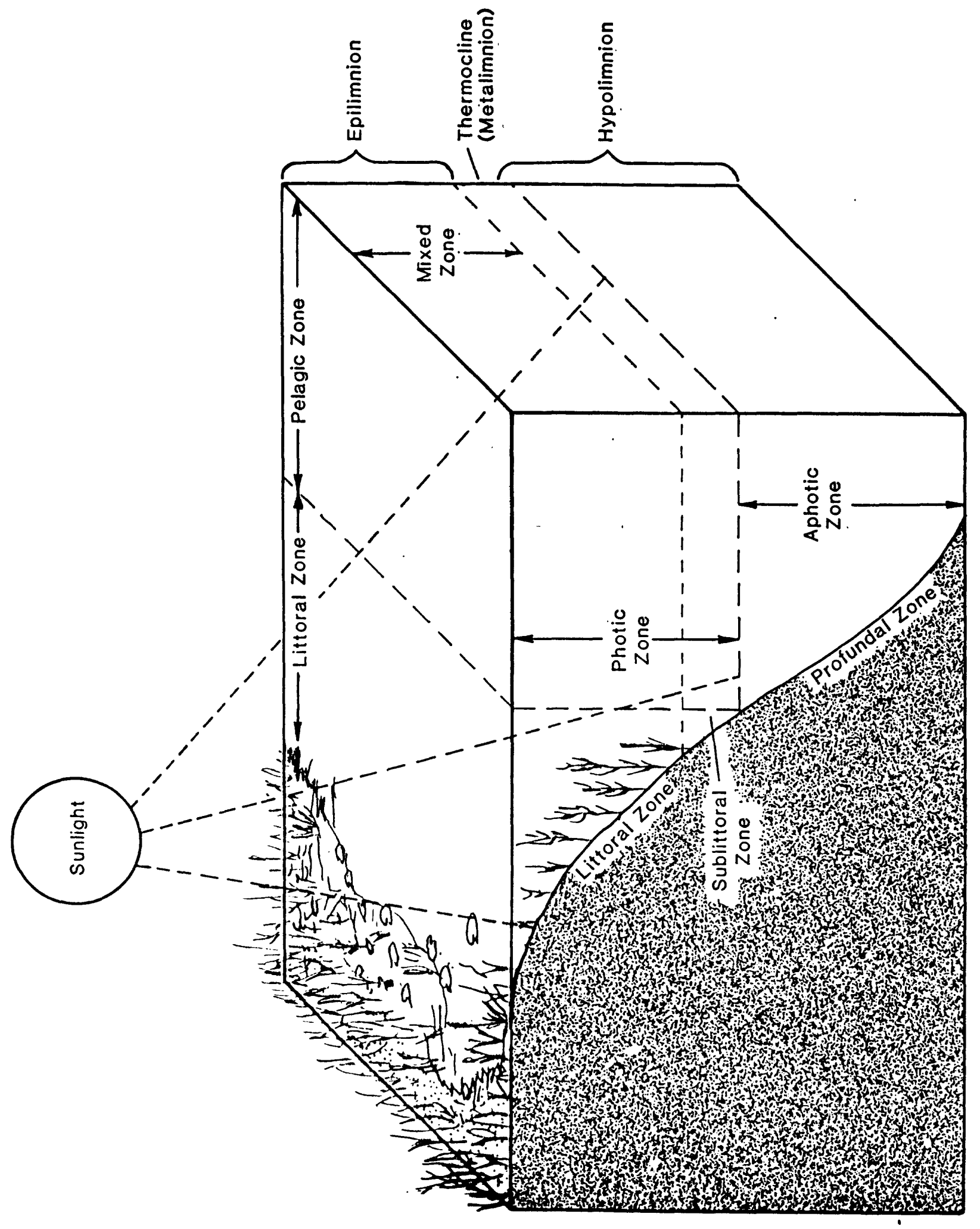

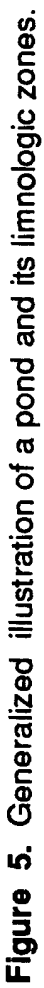


were selected for each coal seam using U.S. Agricultural Stabilization and Conservation Service aerial photographs provided by county Soil Conservation offices. To decrease selection bias caused by personal preferences, the first ponds found in the photographs and verified in the field were used.

The six control ponds also were selected using aerial photographs. The control ponds had to meet several criteria including location, size and depth, and amount of inflow. The ponds had to be located in the coal-mining region but not receive water from mined land. The control ponds had to be similar to ponds formed by strip mining in size and depth. A criterion for selecting a control pond was that the pond have little or no surface inflow. The influence of stream biology on the biology of the ponds was minimized by this stipulation. Most of the ponds formed by strip mining are closed ponds, and those with inlets receive only intermittent inflow.

An additional McAlester mine pond (McAlester Pond 6), excavated before the Surface Mining Control and Reclamation Act act of 1977, was selected to compare with a mine pond 2 miles away (McAlester Pond 5), which was excavated soon after implementation of the reclamation act.

\section{Data Coliection and Anaiysis}

The 26 ponds formed by strip mining and 6 control ponds were sampled in the spring and summer of 1985 , because of possible differences in water quality between the seasons. During the spring the water level is usually at its maximum and the water diluted by spring rains. During the summer, the ponds usually stratify and the bottom becomes anoxic, releasing trace elements and sulfides. The water levels are low and constituent concentrations are larger. Both spring and summer samples were analyzed for major dissolved chemical constituents and dissolved and total recoverable phases of trace elements. Dissolved constituents are defined as particles passing through a 0.45 micron $(\mu \mathrm{m})$ filter. Total recoverable constituents are those constituents in solution after acidic digestion and include all readily soluble substances attached to sediment particles. Samples collected in the summer also were analyzed for plant nutrients, chlorophyll, phytoplankton, and benthic invertebrates.

Three to five vertical profiles were measured in each pond during each sampling trip. Temperature, $\mathrm{pH}$, dissolved oxygen, and specific conductance were measured at 1 to 5 foot intervals, depending on the total depth, using a multi-parameter meter. A Secchi disk was used to measure the relative transparency of the ponds. A Secchi disk is a black and white disk, 20 centimeters in diameter, that is lowered into the pond until it disappears from sight and then raised slowly until it reappears. The arithmetic mean of the distance at which the disk disappears and reappears is the Secchidisk depth. This depth is not an actual measure of light penetration, but is a relative index of visibility and is useful in making comparisons (Reid and Wood, 1976).

A water sample was collected at mid depth on ponds that were not thermally stratified and where the specific conductance did not vary with depth by more than 25 percent. On ponds where the specific conductance changed by more than 25 percent, two samples were collected, one near the surface and one near the bottom. A horizontal polyvinylchloride (PVC) water sampler was used to collect the water sample. Alkalinity was analyzed on site by titrating the sample with a standard solution of 0.01639 Normal sulfuric acid to an inflection point. Samples for analysis of the remaining chemical constituents were pretreated following methods of the U.S. Geological Survey (Brown and others, 1970), and were analyzed at the Oklahoma Geological Survey laboratory in Norman, Oklahoma, using methods described by Skougstad and others (1979).

Dissolved-solids concentrations were determined from the weight of the dry residue remaining after evaporation of an aliquot of the water sample and calculated by summing major dissolved constituents. Specific conductance, which can be measured easily in the field, was used in the vertical profiles as a surrogate measure of dissolved solids. Total dissolved solids concentrations can be estimated from specific conductance.

Phytoplankton and chlorophyll samples were collected using a horizontal PVC water sampler at each site on the pond. A sample was collected at the point of largest oxygen concentration. This point often indicates an area of large algal productivity. A liter sample was preserved with Lugol's solution and sent to a private laboratory for identification of phytoplankton genera. Water samples to be analyzed for chlorophyll were filtered through a $0.45 \mu \mathrm{m}$-pore-size glass filter and frozen. As much of a 1.5-liter sample was filtered as possible before the filter clogged. The filtered sample was frozen and sent to private laboratory for analysis of chlorophyll A, B, and C using methods described in Standard Methods for the Examination of Water and Wastewater (American Public Health Association and others, 1985). Results of analysis for chlorophyll A, B, and $\mathrm{C}$ are given in table 1 (at back of report).

Benthic invertebrate samples were collected using a Ponar grab sampler with a sampling area of $36 \mathrm{in}^{2}$. 
The Ponar samples for each pond were composited.

The benthic invertebrates collected by the Ponar sampler were used to estimate the number of organisms per $\mathrm{m}^{2}$ found on the bottom of the pond. A large component of the benthic population can be found near the shore. However, a Ponar sampler could not be used near the shore because of interference from rooted plants. A dip net was used to sample this area. A dipnet sample is a qualitative sample and does not allow for comparison of populations. The invertebrates collected using the dip net were listed only as being present. The data from the dip net sample were used to estimate the number of benthic invertebrate genera found in the pond. Both Ponar and dip-net samples were washed using a 520- $\mu \mathrm{m}$-mesh wash frame, and preserved with formaldehyde. The samples were analyzed by a private laboratory.

\section{RATIONALE FOR WATER-QUALITY CRITERIA}

Water-quality criteria are recommended values for concentrations of constituents that, if not exceeded, are expected to result in an aquatic ecosystem suitable for a particular use. Criteria are not rules or regulations, and in this report are intended as guidelines only. The criteria recommended by the U.S. Environmental Protection Agency (EPA) were used where available. Where no criteria were listed by the EPA, other sources were used. Water-quality variables used as criteria differ for each water-use category.

Water-quality standards, which differ from criteria, exist for public water supplies and for the protection of aquatic life. These standards are regulations set by either the EPA or state regulatory agencies. In Oklahoma, the state agency responsible for establishing water-quality standards is the Oklahoma Water Resources Board. Where appropriate, the water-quality standards are used as criteria.

\section{Secchi-disk Depth}

All natural waters contain matter in either dissolved or suspended-particulate form. Although both forms can impart color to water, the suspended-particulate form has the greatest effect on water clarity (Wetzel, 1975). Suspended particulates may be either plankton or suspended sediments. The quantity of suspended-particulate matter can be estimated by the Secchi-disk depth. The Secchi-disk depth of eutrophic and muddy ponds ranges from 0 to $2 \mathrm{~m}$, but may be as great as $40 \mathrm{~m}$ in highly oligotrophic ponds or the open ocean (Goldman and Horne, 1983).

As a matter of safety, a criterion for clarity of water for swimming is a Secchi-disk depth of $1.22 \mathrm{~m}$ or 48 inches. This value is more critical in areas where people might be diving (National Technical Advisory Committee to the Secretary of the Interior, 1968).

\section{pH}

An important factor in the chemical and biological processes of natural waters is $\mathrm{pH}$. The abbreviation " $\mathrm{pH}$ " represents the negative base- $10 \mathrm{log}$ of the hydrogen-ion activity in moles per liter (Hem, 1985). The larger the concentration of hydrogen ions, the smaller the $\mathrm{pH}$ value. Large or small concentrations of hydrogen ions may adversely affect water for one or more uses. The hydrogen ion can be a pollutant by itself, but often controls the concentration of other substances (McKee and Wolf, 1963). The degree of disassociation of weak acids or bases is affected by changes in $\mathrm{pH}$. The toxicity of many compounds is affected by the degree of disassociation. The solubility of metal compounds contained in bottom sediments or as suspended material is affected by $\mathrm{pH}$ (U.S. Environmental Protection Agency, 1986a).

The $\mathrm{pH}$ of public water supplies affects taste, corrosiveness, and the efficiency of chlorination and other treatment processes. The EPA (1986c) has suggested a pH range of 6.5 to 8.5 as a secondary standard for public water supplies.

Many physiological processes in fish are affected by low $\mathrm{pH}$. The toxic effect of low $\mathrm{pH}$ differs among species, populations, and age groups of the same species. Low pH could increase susceptibility to disease, increase the chance of genetic damage, change predator-prey relationships, degrade habitat, decrease productivity, and increase the availability of toxic substances (Fritz, 1980). High pH also may be detrimental. The toxicity of ammonia increases as $\mathrm{pH}$ increases. A pH range of 6.5 to 9.0 has been set as the criterion for the protection of fish and other aquatic organisms (U.S. Environmental Protection Agency, 1986a).

The $\mathrm{pH}$ of water will have an indirect effect on waterfowl. The growth of aquatic plants used by waterfowl for food and cover is adversely affected by either a low or high $\mathrm{pH}$. The $\mathrm{pH}$ criterion for waterfowl is 7.0 to 9.2, based on values at which submersed aquatic plants thrive (National Technical Advisory Committee to the Secretary of the Interior, 1968; Ferreira and Lambing, 1984). Aquatic invertebrates which may be used as food by some waterfowl also are affected by the 
$\mathrm{pH}$ of the water. The $\mathrm{pH}$ criterion for aquatic life is 6.5 to 9.0 .

The $\mathrm{pH}$ of irrigation water is important in some situations. Soils generally have a large buffering capacity and the $\mathrm{pH}$ of the water applied is changed to that of the soil. However, in acid soils, metallic ions such as iron, manganese, and aluminum may be dissolved, resulting in concentrations in the water that are toxic to plants. Under alkaline conditions, sodium carbonates and bicarbonates may be dangerously toxic. To avoid these undesirable effects, the $\mathrm{pH}$ of irrigation water should not exceed a pH range of 4.5 to 9.0 (U.S. Environmental Protection Agency, 1986a).

The $\mathrm{pH}$ of the water also may affect swimmers. Documentation shows that water having extreme $\mathrm{pH}$ values may cause increased eye irritation. The lacrimal fluid of the human eye has a normal $\mathrm{pH}$ of 7.4. Although lacrimal fluid is strongly buffered, once buffering capacity is exhausted during swimming, eye irritation may result and lead to infection. In waters with $\mathrm{pH}$ values ranging from 6.5 to 8.3 , the buffering capacity of tears will prevent irritation. If the water is relatively free of dissolved solids and has a low alkalinity, $\mathrm{pH}$ values from 5.0 to 9.0 may be acceptable to most swimmers. (National Academy of Sciences and National Academy of Engineering, 1973). In this report, a pH range of 6.5 to 8.3 is used as the criterion for recreational use.

\section{Water Temperature}

Water temperature affects the rate of both chemical and biological processes. The toxicity of a given substance will generally increase with increased temperature, and organisms subjected to stress from toxic materials are less tolerant to temperature extremes. Increased temperatures accelerate the biodegradation of organic material both in the water column and in bottom deposits, thus increasing demands on the dissolved oxygen resources of a pond. Temperature affects the amount of available dissolved oxygen in water, because the solubility of oxygen in water is inversely proportional to temperature. Temperature also affects the rate at which fish utilize oxygen. The lower the temperature, the less oxygen required (U.S. Environmental Protection Agency, 1986a).

Because aquatic organisms are poikilothermic or "cold-blooded", the temperature of the water regulates their metabolism and ability to survive and reproduce effectively. Temperature also affects respiration, behavior, distribution and migration, feeding rate, and growth of aquatic organisms. Elevated temperatures affect benthic invertebrates, periphyton, and fish, and may cause shifts in algal predominance. The number and distribution of bottom organisms decrease as water temperatures increase. The upper tolerance limit for a balanced benthic population structure is approximately $32^{\circ} \mathrm{C}$ (U.S. Environmental Protection Agency, 1986a).

The effect of temperature on fish varies with the species. Reproduction and survival of embryos is the most temperature sensitive of all life functions.

Growth is the next most sensitive. Table 2 lists the values for maximum weekly average temperatures needed

Table 2. Values for maximum weekly average temperatures for growth and short-term maximum temperature for survival of juvenile and adult fish species, in degrees Celsius $[--$, no data available; modified from U.S. Environmental Protection Agency (1986a)]

\begin{tabular}{lcc}
\hline \multicolumn{1}{c}{ Species } & Growth & Survival \\
\hline Black crappie & 27 & -- \\
Bluegill & 32 & 35 \\
Channel catfish & 32 & 35 \\
Emerald shiner & 30 & -- \\
Largemouth bass & 32 & 34 \\
White crappie & 28 & - \\
Yellow perch & 29 & -- \\
Average & 30 & 35 \\
\hline
\end{tabular}

for growth and the short-term maximum for survival of juvenile and adult fish species. Maximum tolerable temperatures for spawning and embryo survival are given in table 3 . The average of the maximum average

Table 3. Values for maximum weekly average temperatures for spawning and short-term maximum temperature for embryo survival, in degrees Celsius

[Modified from McKee and Wolf (1963) and U.S. Environmental Protection Agency (1986a)]

\begin{tabular}{lcc}
\hline \multicolumn{1}{c}{ Species } & Spawning & Embryo survival \\
\hline Black crappie & 17 & 20 \\
Bluegill & 25 & 34 \\
Channel catfish & 27 & 29 \\
Emerald shiner & 24 & 28 \\
Largemouth bass & 21 & 27 \\
Striped bass & 18 & 24 \\
White crappie & 18 & 23 \\
Yellow perch & 12 & 20 \\
Average & 20 & 26 \\
\hline
\end{tabular}


temperatures for spawning is used as the spring temperature criterion for aquatic life. The average of the maximum average temperatures for growth is used as the summer temperature criterion.

Juvenile and adult fish usually seek water having a temperature closest to their thermal preference. (U.S. Environmental Protection Agency, 1986a). Fish may move to deeper parts of a pond to avoid warmer surface water temperatures. However, the coolest part of a pond, the hypolimnion, may be anoxic. In this report the coolest temperature in the area with a dissolved oxygen of $5 \mathrm{mg} / \mathrm{L}$ or greater is used for comparison with the maximum-temperature criterion of $20^{\circ} \mathrm{C}$ in the spring and $30^{\circ} \mathrm{C}$ in the summer.

High water temperatures also may adversely affect waterfowl. Conditions favorable for outbreaks of botulism tend to be associated with or affected by temperature above $21^{\circ} \mathrm{C}$ (National Academy of Sciences and National Academy of Engineering, 1973).

Increased water temperature does not have a detrimental effect on livestock watering, irrigation or recreation. Temperature may indirectly affect livestock watering and recreation as it affects growth of nuisance phytoplankton species and the amount of dissolved oxygen and, therefore, the existing aesthetic and sanitary qualities. No criterion has been suggested.

\section{Dissolved Oxygen}

Dissolved oxygen is of major concern because it is important for the maintenance of aquatic life and the protection of waterfowl. The solubility of oxygen in water is a function of water temperature, barometric pressure, and dissolved-solids concentration. Oxygen diffuses from the atmosphere and is produced by photosynthesis. Photosynthesis can cause an increase in the dissolved-oxygen concentration in water to supersaturated levels. Decreases in oxygen can be attributed to the respiration of plants and animals, an increase in temperature, and aerobic decomposition of organic matter.

The oxygen requirement of fish varies with species and with temperature. A minimum concentration of $5.0 \mathrm{mg} / \mathrm{L}$ has been set by U.S. Environmental Protection Agency (1986a) as the dissolved oxygen criterion for the maintenance of aquatic life. This concentration will support a diverse fish population, although some species of fish require a larger concentration of dissolved oxygen. Oklahoma's standard for the protection of warm-water fisheries is $5.0 \mathrm{mg} / \mathrm{L}$ (Oklahoma Water Resources Board, 1993), and that criterion is used in this report.
Dissolved oxygen also is important for waterfowl protection. Botulism, which annually can cause significant mortality to waterfowl populations, is caused by a toxin produced by bacteria under anaerobic conditions (Smith, 1976). Outbreaks of botulism also have been associated with insect die-offs, water temperature above $21^{\circ} \mathrm{C}$, fluctuating water levels, and elevated concentrations of dissolved solids (National Academy of Sciences and National Academy of Engineering, 1973). Ponds in which the dissolved oxygen concentration is zero somewhere in the water column are less desirable to waterfowl than ponds that have a greater concentration of oxygen throughout the water column. Hydrogen sulfide production is an indicator of bacterial decomposition in the absence of oxygen (U.S. Environmental Protection Agency, 1986a). Where hydrogen sulfide is present, dissolved oxygen is absent at equilibrium. However, at very low concentrations of dissolved oxygen, the precision of dissolved-oxygen meters is poor. Dissolved-oxygen concentrations as high as $0.5 \mathrm{mg} / \mathrm{L}$ may be read on meters when a hydrogen sulfide smell is present, indicating anaerobic decomposition. Therefore, $0.5 \mathrm{mg} / \mathrm{L}$ of dissolved oxygen is used as the criterion for waterfowl protection.

\section{Alkalinity and Hardness}

The alkalinity of a solution is the capacity of its constituents to react with and neutralize acid. Therefore, alkalinity buffers the solution against changes in $\mathrm{pH}$. Because $\mathrm{pH}$ has a direct effect on organisms as well as an indirect effect on the toxicity of other constituents, the buffering capacity is important. In most natural waters, alkalinity is produced by the dissolved carbon dioxide species bicarbonate and carbonate. Hydroxide, silicate, borate, and organic ligands also contribute to alkalinity (Hem, 1985).

Alkalinity is important for aquatic life because it buffers $\mathrm{pH}$ changes that occur naturally as a result of photosynthesis. Components of alkalinity such as carbonate and bicarbonate will react with some toxic heavy metals and reduce their toxicity (National Academy of Sciences and National Academy of Engineering, 1973). A minimum alkalinity of $20 \mathrm{mg} / \mathrm{L}$ reported as calcium carbonate $\left(\mathrm{CaCO}_{3}\right)$ is recommended for the protection of aquatic life (U.S. Environmental Protection Agency, 1986a).

Ponds with low total alkalinities generally have fewer nutrients and therefore cannot support extensive growth of aquatic plants. Aquatic plants are an important component of waterfowl habitat. A total alkalinity of $25 \mathrm{mg} / \mathrm{L}$ as $\mathrm{CaCO}_{3}$ or more is recommended for wa- 
terfowl habitat (National Technical Advisory Committee to the Secretary of the Interior, 1968).

An excessive alkalinity will affect the desirability of the water for recreation. High alkalinity can cause problems for swimmers by altering the $\mathrm{pH}$ of the lacrimal fluid (see section on $\mathrm{pH}$ ), but no criterion has been set by State or federal regulations.

The concept of hardness was derived from water-supply practice. It is measured by soap requirements for adequate lather formation and is used as an indicator of the rate of scale formation (U.S. Environmental Protection Agency, 1986a). Total hardness was calculated from calcium, magnesium, and barium concentrations and converted to an equivalent concentration of calcium carbonate (Brown and others, 1970). Strontium is often included in the hardness calculation but no analysis was made for it in this study. Many public water supplies soften the water to fewer than $100 \mathrm{mg} / \mathrm{L}$. As hardness in water can be removed and is not a health hazard, it is not regulated by the EPA. A hardness criterion of $100 \mathrm{mg} / \mathrm{L}$ is used in this report as a basis for comparison. A commonly used classification for hardness is given in table 4.

Table 4. Classification of water by hardness concentration [Hardness is given in $\mathrm{mg} / \mathrm{L} \mathrm{CaCO}_{3}$; modified from Sawyer (1960); U.S. Environmental Protection Agency (1986a)

\begin{tabular}{cc}
\hline Hardness range & Classification \\
\hline $0-75$ & soft \\
$75-150$ & moderately hard \\
$150-300$ & hard \\
over 300 & very hard \\
\hline
\end{tabular}

\section{Dissoived Sollds and Speciflc Conductance}

Where available, the total dissolved-solids concentration derived from the residue on evaporation at $180^{\circ} \mathrm{C}$ is used to compare water-quality data from the ponds to the dissolved-solids criterion. Where no dissolved-solids data are available, the specific conductance data are compared to a specific conductance criterion estimated from the total dissolved-solids criterion. The ratio of total dissolved-solids concentration to specific conductance usually falls between 0.55 and 0.75 for natural waters. The larger values generally are associated with water that have larger sulfate concentrations (Hem, 1985). The mean ratio of total dissolved-solids concentration to specific conductance for the study ponds with paired data was 0.75 . This ratio is used to calculate a specific conductance criterion from the total dissolved-solids criterion. When a water sample from a pond has a dissolved-solids concentration close to the criterion it is possible for the dissolved-solids concentration to be higher than the criterion and the specific conductance lower than the corresponding criterion, or vice versa. In this case the total dissolved-solids criterion will be used for comparison.

Many plant and animal species are affected by dissolved-solids concentrations, although tolerance varies considerably among different species. Dissolved-solids concentrations are regulated by the EPA as a secondary drinking-water standard. Large concentrations of dissolved solids are objectionable in drinking water because of possible physiological effects, unpalatable mineral tastes, and higher production costs for a water supply necessitated by replacement of corroded water lines or additional treatment of the water. The recommended dissolved-solids limit is $500 \mathrm{mg} / \mathrm{L}$ where other sources are not available (U.S. Environmental Protection Agency, 1986c)

Large concentrations of dissolved solids can cause detrimental physiological effects in fish. The concentrations that fish can tolerate vary with the species. Dissolved-solids concentrations in excess of $15,000 \mathrm{mg} / \mathrm{L}$ are reported as unsuitable for most species of freshwater fish (U.S. Environmental Protection Agency, 1986a). However, concentrations in excess of $5,000 \mathrm{mg} / \mathrm{L}$ are unsuitable for spawning of largemouth bass (Ferreira and Lambing, 1984), a species stocked in many strip-mine and farm ponds in Oklahoma. Therefore, a dissolved-solids concentration of $5,000 \mathrm{mg} / \mathrm{L}$ and a specific conductance of $6,700 \mu \mathrm{S} / \mathrm{cm}$ are used as the criteria.

Water with excessive concentrations of dissolved solids can cause physiological damage and death of livestock. Among the functions of animals, reproduction and lactation are affected first. The maximum amount tolerated by livestock varies with species (table 5). The concentration of total dissolved solids tolerated by livestock also depends on the type of dissolved constituents present, climate, and other factors. Some species can tolerate higher concentrations of dissolved solids than those listed in table 5 for short periods of time (Oklahoma Water Resources Board, 1993). Two criteria are used, one of $2,860 \mathrm{mg} / \mathrm{L}$ for livestock sensitive to dissolved solids, and a criterion of 15,600 $\mathrm{mg} / \mathrm{L}$ for livestock with high tolerance.

The suitability of water for irrigation also depends on the dissolved-solids concentration. Both the 
osmotic effect of dissolved solids and the ratio of the various cations present are important. The EPA has set

Table 5. Maximum concentration of dissolved solids recommended for various livestock

[mg/L, milligrams per liter, modified from McKee and Wolf (1963)]

\begin{tabular}{lc}
\hline \multicolumn{1}{c}{ Animal } & Concentration (mg/L) \\
\hline Poultry & 2,860 \\
Pigs & 4,290 \\
Horses & 6,435 \\
Dairy cattle & 7,150 \\
Beef cattle & 10,100 \\
Adult sheep & 12,900 \\
\hline
\end{tabular}

levels for dissolved solids to use as a guide for irrigation (table 6). The criterion for sensitive crops is $500 \mathrm{mg} / \mathrm{L}$ total dissolved solids $(670 \mu \mathrm{S} / \mathrm{cm}$ specific conductance). The criterion used for semitolerant plants is $1,000 \mathrm{mg} / \mathrm{L}$ total dissolved solids $(1,330$ $\mu \mathrm{S} / \mathrm{cm}$ specific conductance). The criterion for tolerant crops is $2,000 \mathrm{mg} / \mathrm{L}$ total dissolved solids $(2,670$ $\mu \mathrm{S} / \mathrm{cm}$ specific conductance). Most crops in Oklahoma are semitolerant to dissolved solids, but crops from all categories are grown here. The sensitive crops include strawberries, beans, and fruit trees. The semitolerant

Table 6. Suitability of water for irrigation based on dissolvedsolids concentrations in arid and semiarid regions [Modified from U.S. Environmental Protection Agency (1986a)]

\begin{tabular}{lc}
\hline \multicolumn{1}{c}{ Suitability } & $\begin{array}{c}\text { Dissolved solids } \\
\text { concentration } \\
\text { in } \mathrm{mg} / \mathrm{L}\end{array}$ \\
\hline $\begin{array}{l}\text { Water from which no detrimental } \\
\text { effects will usually be noticed }\end{array}$ & under 500 \\
$\begin{array}{l}\text { Water that may have detrimental effects } \\
\text { on sensitive crops }\end{array}$ & $500-1,000$ \\
$\begin{array}{l}\text { Water that may have detrimental effects } \\
\text { on crops and requires careful man- } \\
\text { agement practices }\end{array}$ & $1,000-2,000$ \\
$\begin{array}{l}\text { Water that may be used for tolerant } \\
\text { plants on permeable soils with } \\
\text { careful management practices }\end{array}$ & $2,000-5,000$ \\
\hline
\end{tabular}

crops include most vegetables, corn, sorghum, and alfalfa. The most tolerant crops are barley and cotton.

\section{Sodium, Sulfate, and Chioride}

Sodium (Na), sulfate, and chloride are the only major constituents in water for which water-quality criteria currently have been established. Chloride and sulfate have secondary maximum contamination levels (SMCL's) which means the constituents are not considered a health risk. Large sulfate concentrations may be detrimental to livestock, and sodium concentration is a limiting factor for irrigation water.

Both chloride and sulfate in large concentrations are detectable by taste. Sulfate also has a laxative effect for people who are not acclimated to the water. The criterion for both sulfate and chloride is $250 \mathrm{mg} / \mathrm{L}$ (U.S. Environmental Protection Agency, 1986a). Water with larger concentrations of sulfate and chloride is acceptable for domestic use when no other source is available. Livestock will tolerate larger concentrations of sulfate. It is recommended that water used for livestock watering not have a sulfate concentration greater than $2,500 \mathrm{mg} / \mathrm{L}$ (Ferreira and Lambing, 1984)

The amount of sodium and the ratio of sodium to other cations is important for irrigation water. Sodiumadsorption ratio (SAR) is the parameter most often used to measure the sodium hazard of irrigation water.

$\mathrm{SAR}=\frac{\mathrm{Na}^{+}}{1 / 2\left[\mathrm{Ca}^{2}+\mathrm{Mg}^{2}\right]}$ where $\mathrm{Na}, \mathrm{Ca}$, and $\mathrm{Mg}$ are expressed in milliequivalents per liter (Hem, 1985). For sensitive crops, such as fruits, the tolerance for sodium in irrigation water is a SAR of 4 . The acceptable range for general crops and forage is a SAR of 8 to 18 (U.S. Environmental Protection Agency, 1986a). This report uses a SAR of 4 as the criterion for sensitive crops and a SAR of 18 as the criterion for tolerant crops.

\section{Nitrogen and Phosphorus}

Nitrogen and phosphorus are common elements and plant nutrients. They are essential for plant growth, but both are pollutants when present in certain forms and in large concentrations. Nitrogen in the form of nitrate and ammonium ions is converted to protein by plants, but both forms may be toxic to man, animals, and fish. Large concentrations of phosphorus as phosphate may cause nuisance aquatic growths.

Both nitrate and nitrite are considered toxic, although nitrite is considered more toxic. Although natural waters often contain high levels of nitrate, the nitrite content is usually very low (National Academy of Sciences and National Academy of Engineering, 
1973). Nitrate becomes toxic when it is reduced to nitrite. Nitrate can be reduced to nitrite in the gastrointestinal tract. Nitrite reacts with hemoglobin in the body to produce methemoglobin, which impairs oxygen transport. This impairment can be hazardous to infants. Therefore nitrate and nitrite is regulated in public water supplies. Limits of $10 \mathrm{mg} / \mathrm{L}$ of nitrate and $1 \mathrm{mg} / \mathrm{L}$ of nitrite are the criteria for public water supplies. protection of aquatic life. The criteria of $90 \mathrm{mg} / \mathrm{L} \mathrm{ni-}$ trate and $5 \mathrm{mg} / \mathrm{L}$ nitrite are used in this report.

Ammonia in the un-ionized form also is detrimental to aquatic life, including fish and invertebrate species. The toxicity of ammonia is affected by temperature, $\mathrm{pH}$, previous acclimation to ammonia, carbon dioxide concentration, salinity, and the presence of other toxicants. EPA's (1986a) recommended wa-

Table 7. Maximum total ammonia concentrations recommended for the protection of aquatic life, in milligrams per liter $\left[{ }^{\circ} \mathrm{C}\right.$, degrees Celsius; Modified from U.S. Environmental Protection Agency (1986a)]

\begin{tabular}{lccccccc}
\hline \multicolumn{7}{c}{ Concentration $(\mathrm{mg} / \mathrm{L}$ as $\mathrm{N}$ ), for indicated values of $\mathrm{pH}$ and temperature } \\
\hline $\mathrm{pH}$ & \multicolumn{7}{c}{ Temperature } \\
\cline { 2 - 8 } & $0^{\circ} \mathrm{C}$ & $5^{\circ} \mathrm{C}$ & $10^{\circ} \mathrm{C}$ & $15^{\circ} \mathrm{C}$ & $20^{\circ} \mathrm{C}$ & $25^{\circ} \mathrm{C}$ & $30^{\circ} \mathrm{C}$ \\
\hline 6.50 & 2.06 & 1.97 & 1.81 & 1.81 & 1.73 & 1.20 & 0.85 \\
6.75 & 2.06 & 1.97 & 1.81 & 1.81 & 1.73 & 1.21 & 0.85 \\
7.00 & 2.06 & 1.97 & 1.81 & 1.81 & 1.73 & 1.21 & 0.85 \\
7.25 & 2.06 & 1.97 & 1.81 & 1.81 & 1.73 & 1.22 & 0.86 \\
7.50 & 2.06 & 1.97 & 1.81 & 1.81 & 1.73 & 1.22 & 0.87 \\
7.75 & 1.89 & 1.81 & 1.73 & 1.64 & 1.63 & 1.14 & 0.82 \\
8.00 & 1.26 & 1.18 & 1.13 & 1.09 & 1.08 & 0.76 & 0.55 \\
8.25 & 0.72 & 0.67 & 0.64 & 0.62 & 0.62 & 0.44 & 0.33 \\
8.50 & 0.40 & 0.39 & 0.37 & 0.36 & 0.37 & 0.27 & 0.21 \\
8.75 & 0.23 & 0.22 & 0.21 & 0.22 & 0.22 & 0.17 & 0.13 \\
9.00 & 0.13 & 0.13 & 0.13 & 0.13 & 0.14 & 0.12 & 0.09 \\
\hline
\end{tabular}

The presence of ammonia may be indicative of pollution. Ammonia reduces the effectiveness of chlorination. It also may be corrosive to copper. The $\mathrm{Na}$ tional Academy of Sciences and National Academy of Engineering (1973) recommends that dissolved ammonia in public water supplies not exceed $0.5 \mathrm{mg} / \mathrm{L}$ as nitrogen $(\mathrm{N})$. Ammonia in drinking water is not considered hazardous to human health.

Nitrates and nitrites also are dangerous to aquatic life. Nitrate concentrations above a level of $90 \mathrm{mg} / \mathrm{L}$ and nitrite concentrations above a level of $5 \mathrm{mg} / \mathrm{L}$ are considered detrimental to warm-water fish. Salmonids such as trout are more sensitive to and are adversely affected by nitrite at a level above $0.06 \mathrm{mg} / \mathrm{L}$. These levels are unlikely to occur in nature and therefore the EPA (1986a) has not included them in the criteria for ter-quality standard for ammonia, based on the protection of aquatic life, is calculated using temperature and $\mathrm{pH}$. Table 7 shows total ammonia values recommended for the protection of aquatic life for specific $\mathrm{pH}$ and temperature values. Total ammonia refers to total dissolved ammonia species. This table applies to all species other than salmonids, which rarely are found in ponds.

Livestock poisoning by nitrate or nitrite is dependent on the intake of these ions from all sources. Nitrite is formed in the rumen of cattle and sheep, in forage, in moistened feeds, and in contaminated water. In order to provide a reasonable margin of safety for unusual situations, such as extremely large water intake or nitrite formation in slurries, the recommended 
limit of nitrate plus nitrite content in drinking water for livestock is $100 \mathrm{mg} / \mathrm{L}$, and the limit for nitrite concentration alone is $10 \mathrm{mg} / \mathrm{L}$ (National Academy of Sciences and National Academy of Engineering, 1973).

Total phosphorus as phosphate is considered a pollutant when in large concentrations because it stimulates excessive algal growth. Excessive algal growth may impart a taste and odor to the water, may clog intake valves, may interfere with water treatment, and may alter the chemistry of the water. Excessive algal growth contributes to cultural eutrophication (U.S. Environmental Protection Agency, 1986a), which is rapid and unnatural aging of lakes because of man's activities. To prevent cultural eutrophication, the EPA recommends that total phosphate not exceed $25 \mathrm{mg} / \mathrm{L}$.

\section{Trace Elements}

Trace elements are those that naturally occur in waters in concentrations of less than a few $\mathrm{mg} / \mathrm{L}$. These elements are generally reported in $\mu \mathrm{g} / \mathrm{L}$. Micrograms per liter is equivalent to parts per billion in fresh water. Many trace elements, in small concentrations, are necessary for plant and animal growth, but become toxic at larger concentrations. Concentrations of trace elements are included in criteria for different uses of water because of the toxicity of different elements to plants, animals, and man at large concentrations. The toxicity of an element often is affected by other characteristics of the water, such as $\mathrm{pH}$, hardness, and the presence of other elements (U.S. Environmental Pro-

Table 8. Trace elements with criteria for various water uses

[MCL, maximum contaminant level; SMCL, secondary maximum contaminant level]

\begin{tabular}{|c|c|c|c|c|c|c|}
\hline \multirow{2}{*}{ Trace element } & \multicolumn{6}{|c|}{ Water use } \\
\hline & Public MCL & Public SMCL & Aquatic life & Waterfowl & Livestock & Irrigation \\
\hline Aluminum & & & & & $\mathrm{X}$ & $\bar{x}$ \\
\hline Arsenic & $\mathbf{X}$ & & $\mathrm{X}$ & & $\mathrm{X}$ & $\mathrm{X}$ \\
\hline Barium & $\mathbf{X}$ & & & & & \\
\hline Boron & & & & & $\mathbf{X}$ & $\mathrm{x}$ \\
\hline Cadmium & $\mathrm{X}$ & & & & $\mathbf{X}$ & $\mathbf{x}$ \\
\hline Chromium & $\mathrm{X}$ & & $\mathbf{X}$ & & $\mathbf{X}$ & $\mathrm{x}$ \\
\hline Copper & & $\mathrm{X}$ & $\mathbf{x}$ & & $\mathbf{x}$ & $\mathbf{x}$ \\
\hline Iron & & $\mathrm{X}$ & $\mathrm{X}$ & & & $\mathrm{X}$ \\
\hline Lead & $\mathbf{x}$ & & $\mathbf{X}$ & & $\mathrm{X}$ & $\mathbf{X}$ \\
\hline Manganese & & $\mathbf{X}$ & & & & $\mathbf{X}$ \\
\hline Mercury & $\mathrm{X}$ & & $\mathrm{X}$ & & $\mathrm{X}$ & \\
\hline Selenium & $\mathrm{x}$ & & $\mathrm{X}$ & $\mathbf{x}$ & $\mathrm{X}$ & $\mathbf{X}$ \\
\hline Zinc & & $\mathrm{X}$ & $\mathbf{X}$ & & $\mathbf{X}$ & $\mathbf{X}$ \\
\hline
\end{tabular}

This report is concerned with naturally occurring water-use limitations rather than man-made problems. However, ponds that are man-made may age faster than those created naturally, therefore, this criterion is used to gauge the level of eutrophication in the lakes. Large concentrations of phosphate in a pond may be caused by nearby land use rather than naturally occurring phosphates. tection Agency, 1986a). Many of the criteria set for trace elements change as new information becomes available on their toxicity. The trace elements with criteria for various water uses are given in table 8.

Both maximum contamination limits and secondary contamination limits consist of some trace element concentrations (table 8). The analytical detection limit for total recoverable lead in the water samples collected in the spring of 1985 is different from the detection limit for lead in the water samples collected in the summer, because of a change in analytical methods. Both detection limits are larger than the criterion for lead in public water supplies. 
The levels at which an element is toxic to aquatic life differ from species to species and differ for specific life cycles of the same species. The $\mathrm{pH}$ and hardness of the water often affect the toxicity of an element, therefore, the criteria given may be functions of these constituents rather than a fixed amount. The criteria for cadmium, chromium, copper, lead, and zinc are functions of hardness. The greater the hardness, the larger the concentration of the element can be before being considered toxic to aquatic species. The waterquality criteria developed by the EPA (1986a) are not intended to provide 100 -percent protection of all species and all uses of aquatic life all of the time, but are intended to protect most species in a balanced, healthy aquatic community. When a criterion is given as an equation, the detection limit may be greater than the criterion for one pond and less than the criterion for another pond. Also, the national water-quality criteria for the protection of aquatic life set by the EPA often have more than one recommended concentration for a given trace element. The criteria are used for streams, rivers, and effluent as well as lakes and ponds. Therefore, the criterion may be a 4-day average concentration or a 1hour average concentration. This report uses the 4-day average concentration as the criterion because water quality in ponds does not change as quickly as in flowing water.

The criteria for the protection of waterfowl include the trace element selenium. Dissolved selenium becomes concentrated in fish, invertebrates, and plants, particularly bottom-rooting plants, on which waterfowl feed. Large selenium concentrations in plants and animals may cause waterfowl mortality and reproduction problems (Brown, 1987). The State of Oklahoma has no criterion for selenium, possibly because information concerning the impact of selenium on waterfowl is fairly recent. The State of California has proposed a standard of between 2 and $10 \mu \mathrm{g} / \mathrm{L}$ of selenium (Brown, 1987). This report uses a criterion of $2 \mu \mathrm{g} / \mathrm{L}$.

Ten trace elements are included in water-quality criteria for the protection of livestock (table 7). These elements may be in both feed and water, so both should be considered. The National Academy of Sciences and National Academy of Engineering (1973) recommends using the criteria as guidelines for diagnosing livestock losses, since a large margin of safety normally is factored into the criteria and other factors such as interaction with other ions, water intake, temperature of the environment, and age, sex, species, and physiological state of the animal are important.

Eleven trace elements are included in waterquality criteria for irrigation (table 8). The most important of these elements is boron. Plants vary in their sensitivity to boron. Water may be classified not only according to its boron content, but also according to the tolerance of the crops to which it is applied. The most sensitive crops are citrus, nuts, and deciduous fruits; semitolerant are truck crops, cereals, and cotton; most tolerant are lettuce, onion, alfalfa, beets, and asparagus (McKee and Wolf, 1963). The Environmental Protection Agency (1986a) suggests a criterion of $0.75 \mathrm{mg} / \mathrm{L}$ for long-term irrigation on sensitive crops. National Academy of Sciences and National Academy of Engineering (1973) recommends maximum boron concentrations of 1 and $2 \mathrm{mg} / \mathrm{L}$ for semitolerant and tolerant plants respectively.

Manganese also may be toxic to some plants at a concentration slightly less than $1 \mathrm{mg} / \mathrm{L}$ when applied to soils with $\mathrm{pH}$ values less than 6.0. For acidophilic crops a criterion of $0.2 \mathrm{mg} / \mathrm{L}$ has been suggested. Problems may develop with long-term (approximately 20 years) continuous irrigation on other soils with water containing about $10 \mathrm{mg} / \mathrm{L}$ of manganese. However, because surface waters rarely have concentrations greater than $1 \mathrm{mg} / \mathrm{L}$, the EPA (1986a) has not set a specific criterion for manganese. Water in Oklahoma tends to contain relatively large concentrations of manganese. Therefore, this report uses $1 \mathrm{mg} / \mathrm{L}$ as a criterion for irrigation.

\section{Phytoplankton, Macrophytes, and Benthlc Invertebrates}

Biological constituents also are used to evaluate the quality of a water body. A healthy population of phytoplankton, macrophytes, and benthic invertebrates are necessary for the health and propagation of fish.

Phytoplankton can be both beneficial and detrimental to the water quality of a pond. Phytoplankton can be beneficial because they produce oxygen, remove carbon dioxide, are significant in self-purification processes, and serve as food for other aquatic fauna, such as zooplankton and some fish. Phytoplankton growths have been known to foster increased growth of insect larvae and water fleas. Phytoplankton also can be damaging to a pond. Some species are toxic to stock, others cause taste and odor problems in public water supplies and clog filters. Phytoplankton can be detrimental to fish. Some species add toxins to the water that poison certain species of fish. Phytoplankton also may cause dissolved oxygen imbalances resulting in mortality through oxygen depletion or supersaturation. Large concentrations of dead phytoplankton can cause fish deaths by clogging their gills and can smother benthic fauna (McKee and Wolf, 1963). 
Table 9. Water-quality criteria and standards for public water supply [EPA, U.S. Environmental Protection Agency; NAS/NAE, National Academy of Sciences and National Academy of Engineering; OWRB, Oklahoma Water Resources Board; MCL, Maximum contaminant level; SMCL, Secondary maximum contaminant level; $\mathrm{mg} / \mathrm{L}$, milligrams/liter, $\mu \mathrm{S} / \mathrm{cm}, \mathrm{microsiemens}$ per centimeter, min, minimum; max, maximum; TR, total recoverable; $\mathrm{mL}$, milliliter; Primary standards are regulations for the protection of human health; Secondary standards are recommended for human welfare]

\begin{tabular}{|c|c|c|c|c|}
\hline Constituent & $\begin{array}{l}\text { Water-quality } \\
\text { criteria }\end{array}$ & $\begin{array}{l}\text { State standard } \\
\text { (OWRB,1993) }\end{array}$ & $\begin{array}{l}\text { Drinking water } \\
\text { standards } \\
\text { (EPA, 1986; } \\
\text { *EPA, 1993) }\end{array}$ & $\begin{array}{l}\text { Source for water- } \\
\text { quality standard }\end{array}$ \\
\hline \multicolumn{5}{|c|}{ Primary standards (MCL): } \\
\hline Nitrate, dissolved as $\mathbf{N}$ & $10 \mathrm{mg} / \mathrm{L}$ & $10 \mathrm{mg} / \mathrm{L}$ & $10 \mathrm{mg} / \mathrm{L}$ & EPA (1986b) \\
\hline Nitrite, dissolved as $\mathrm{N}$ & $1 \mathrm{mg} / \mathrm{L}$ & & * $1 \mathrm{mg} / \mathrm{L}$ & EPA (1986b) \\
\hline Arsenic, TR & $0.05 \mathrm{mg} / \mathrm{L}$ & $0.1 \mathrm{mg} / \mathrm{L}$ & $.05 \mathrm{mg} / \mathrm{L}$ & EPA (1986b) \\
\hline Barium, TR & $1.0 \mathrm{mg} / \mathrm{L}$ & $1.0 \mathrm{mg} / \mathrm{L}$ & $* 2.0 \mathrm{mg} / \mathrm{L}$ & EPA (1986b) \\
\hline Cadmium, TR & $0.01 \mathrm{mg} / \mathrm{L}$ & $0.02 \mathrm{mg} / \mathrm{L}$ & $* .005 \mathrm{mg} / \mathrm{L}$ & EPA (1986b) \\
\hline Chromium, TR & $0.05 \mathrm{mg} / \mathrm{L}$ & $0.05 \mathrm{mg} / \mathrm{L}$ & *.1 mg/L & EPA (1986b) \\
\hline Copper, TR & $1.0 \mathrm{mg} / \mathrm{L}$ & $1.0 \mathrm{mg} / \mathrm{L}$ & $\begin{array}{l}\text { Treatment } \\
\text { technique }\end{array}$ & EPA (1986c) \\
\hline Lead, TR & $0.05 \mathrm{mg} / \mathrm{L}$ & $0.10 \mathrm{mg} / \mathrm{L}$ & $\begin{array}{l}\text { Treatment } \\
\text { technique }\end{array}$ & EPA (1986b) \\
\hline Mercury, TR & $0.002 \mathrm{mg} / \mathrm{L}$ & $0.002 \mathrm{mg} / \mathrm{L}$ & $.002 \mathrm{mg} / \mathrm{L}$ & EPA (1986c) \\
\hline Selenium, TR & $0.01 \mathrm{mg} / \mathrm{L}$ & $0.01 \mathrm{mg} / \mathrm{L}$ & $* .05 \mathrm{mg} / \mathrm{L}$ & EPA (1986c) \\
\hline \multicolumn{5}{|c|}{ Secondary standards (SMCL): } \\
\hline $\mathrm{pH}$ & $6.5-8.5, \min -\max$ & & $6.5-8.5$ & EPA (1986c) \\
\hline Dissolved oxygen & $5.0 \mathrm{mg} / \mathrm{L}$ & & & EPA (1986c) \\
\hline Hardness, as $\mathrm{CaCO}_{3}$ & $100 \mathrm{mg} / \mathrm{L}$ & & & See text \\
\hline Sulfate, dissolved & $250 \mathrm{mg} / \mathrm{L}$ & & * $250 \mathrm{mg} / \mathrm{L}$ & EPA (1986c) \\
\hline Chloride, dissolved & $250 \mathrm{mg} / \mathrm{L}$ & & * $250 \mathrm{mg} / \mathrm{L}$ & EPA (1986c) \\
\hline Dissolved solids & $500 \mathrm{mg} / \mathrm{L}$ & & $500 \mathrm{mg} / \mathrm{L}$ & EPA (1986c) \\
\hline Specific conductance & $670 \mathrm{mS} / \mathrm{cm}$ & & & See text \\
\hline Ammonia, dissolved & $0.5 \mathrm{mg} / \mathrm{L}$ & & & NAS/NAE (1973) \\
\hline Copper, TR & $1.0 \mathrm{mg} / \mathrm{L}$ & $1.0 \mathrm{mg} / \mathrm{L}$ & $* 1.0 \mathrm{mg} / \mathrm{L}$ & EPA (1986c) \\
\hline Iron, $\mathrm{TR}$ & $0.3 \mathrm{mg} / \mathrm{L}$ & & $* .3 \mathrm{mg} / \mathrm{L}$ & EPA (1986c) \\
\hline Manganese, TR & $0.05 \mathrm{mg} / \mathrm{L}$ & & $* .05 \mathrm{mg} / \mathrm{L}$ & EPA (1986c) \\
\hline Zinc, TR & $5 \mathrm{mg} / \mathrm{L}$ & $5 \mathrm{mg} / \mathrm{L}$ & $* 5 \mathrm{mg} / \mathrm{L}$ & EPA (1986c) \\
\hline Phytoplankton: & & & & McKee and Wolf (1963) \\
\hline Aphanizomenon & 1,000 cells $/ \mathrm{ml}$ & & & \\
\hline Anabaena & $600 \mathrm{cells} / \mathrm{ml}$ & & & \\
\hline Cryptomonas & 200 cells $/ \mathrm{ml}$ & & . & \\
\hline Chlamydomonas & 10 cells/ml & & & \\
\hline Dinobryon & 500 cells $/ \mathrm{ml}$ & & & \\
\hline Synura & 200 cells $/ \mathrm{ml}$ & & & \\
\hline Ureglenopsis & 200 cells/ml & & & \\
\hline
\end{tabular}


The phytoplankton Aphanizomenon, Anabaena, Cryptomonas, Chlamydomonas, Dinobryon, Synura, and Uroglenopsis have been noted to cause odor and taste problems (McKee and Wolf, 1963) in domestic water. Only Anabaena, Chlamydomonas, and Dinobryon were found in the ponds in this study. These taxa and the allowable limits are listed in table 9.

Anacystis, Anabaena, Aphanizomenon, Coelosphaerium, Gloeotrichia, Gomphosphaeria, Nostoc, and Nodularia are considered toxic to stock (National Academy of Sciences and National Academy of Engineering, 1973). Anacystis and Anabaena were found in the ponds in the study. The concentration of these taxa necessary to cause toxic reactions in stock is unknown. Therefore, the presence of the taxon or taxa is noted, but no numerical limit is used as a criterion.

The presence of benthic invertebrates in a pond is generally beneficial to fish as it indicates a food source. However, some genera of benthic invertebrates, particularly midges, mosquitoes, and biting flies may be considered a nuisance in large numbers and will detract from the aesthetics of a pond. The total number of invertebrates and the number of genera are used to compare ponds. The presence of benthic invertebrates is used as a criterion for aquatic life.

Macrophytes generally are considered beneficial to the aquatic life of a pond. Macrophytes are a source of habitat and food for fish, invertebrates, and waterfowl. However, an overabundance may be considered a pollution source. Macrophytes may affect the color and taste of water, may cause problems by clogging pipes, and may affect the dissolved-oxygen content of the water. Decaying macrophytes will lower dissolved oxygen. Macrophyte concentrations were not analyzed quantitatively and will be used only for comparison and not as a criterion.

\section{COMPARISON OF POND DATA TO WATER-QUALITY CRITERIA}

Water-quality data collected from the study ponds were analyzed statistically for the maximum, minimum, and mean values of each constituent for each pond. These values were used for comparison with water-quality criteria. The number of ponds per group with a water sample containing constituent concentrations that exceeded a criterion and the total number of ponds with data per group are noted.

Samples were collected in the spring and summer in an attempt to give a best- and worst-case sample. Two samples are not sufficient to show true seasonal changes. Concentrations of dissolved oxygen, $\mathrm{pH}$, and specific conductance were obtained in vertical profiles (table 10, at back of report) to provide values from the entire water column, rather than from just one point, which could be compared with criteria where appropriate. Concentrations of dissolved oxygen, $\mathrm{pH}$, temperature, and specific conductance obtained from the hypolimnion of the vertical profiles were used to compare with criteria when similar data from the hypolimnion were not available. These data are presented in the comparison tables (tables 11, 17, 21, 23, 25, 27, 28).

The phytoplankton data should be used qualitatively, rather than quantitatively. A pond may have been sampled during a plankton bloom, whereas the next pond may have been sampled before or after a similar bloom. Therefore, the data should be reviewed for types of plankton and number and diversity of genera, rather than for total number of plankton.

\section{Public Water Suppiy}

Water-quality criteria for public water supply are the most closely monitored and regulated criteria. The EPA sets maximum contaminant levels (MCL's) for constituents considered harmful to human health. Secondary maximum contaminant levels (SMCL's) are set for those constituents that are not harmful to human health, but may affect human welfare, such as domestic uses other than ingestion. This report also uses criteria for substances that are not regulated by the EPA. These are grouped with the SMCL's.

The water-quality criteria used in this report, Federal water-quality standards and State water-quality standards, are presented in table 9. Comparison of water-quality data from the ponds to water-quality criteria for public water supplies is given in table 11.

Water samples from six ponds exceeded a standard for the protection of human health in the epilimnion. A water sample from the epilimnion of one Iron Post pond exceeded the lead criterion of $50 \mu \mathrm{g} / \mathrm{L}$ with a concentration of $160 \mu \mathrm{g} / \mathrm{L}$. Water samples from other ponds had lead concentrations less than the detection limit. The detection limit for total recoverable lead of $100 \mu \mathrm{g} / \mathrm{L}$ is lower than the criterion. Therefore, it is possible that the water in some ponds with lead concentrations less than the detection limit had lead concentrations that exceeded the criterion. A water sample from the epilimnion of a McAlester pond had a total recoverable mercury concentration of $50 \mu \mathrm{g} / \mathrm{L}$ that exceeded the MCL of $2 \mu \mathrm{g} / \mathrm{L}$. Only one of the two samples collected during the study for each of these two ponds had concentrations exceeding the criterion mentioned. The other samples collected from these ponds contained 
Table 11. Comparison of pond-water quality to water-quality criteria for public water supply

[min, minimum; max, maximum; *, detection limit is higher than criterion; TR, total recoverable; NA, not applicable. The fraction used is the number of ponds exceeding the criterion over the total number of ponds with data; shallow samples were collected from the epilimnion; deep samples were collected from the hypolimnion]

\begin{tabular}{|c|c|c|c|c|c|c|c|c|}
\hline \multirow{3}{*}{ Variable } & \multicolumn{8}{|c|}{ Pond type and location of sample } \\
\hline & \multicolumn{2}{|c|}{ Control } & \multicolumn{2}{|c|}{ Croweburg } & \multicolumn{2}{|c|}{ Iron Post } & \multicolumn{2}{|c|}{ McAlester } \\
\hline & Shallow & Deep & Shallow & Doep & Shallow & Deep & Shallow & Deep \\
\hline \multicolumn{9}{|c|}{ PRIMARY STANDARDS } \\
\hline Nitrate, dissolved & $0 / 4$ & $0 / 4$ & $0 / 8$ & $0 / 8$ & $0 / 8$ & $0 / 3$ & $0 / 8$ & $0 / 5$ \\
\hline Nitrite, dissolved & $0 / 4$ & $0 / 4$ & $0 / 8$ & $0 / 8$ & $0 / 8$ & $0 / 3$ & $0 / 8$ & $0 / 5$ \\
\hline Arsenic, TR & $0 / 6$ & $0 / 2$ & $0 / 8$ & $0 / 6$ & $0 / 8$ & $0 / 5$ & $0 / 8$ & $0 / 6$ \\
\hline Barium, TR & $0 / 6$ & $0 / 2$ & $0 / 8$ & $0 / 6$ & $0 / 8$ & $0 / 5$ & $0 / 8$ & $0 / 6$ \\
\hline Cadmium, TR & $0 / 6$ & $0 / 2$ & $0 / 8$ & $0 / 6$ & $0 / 8$ & $0 / 5$ & $0 / 8$ & $0 / 6$ \\
\hline Chromium, TR & $0 / 6$ & $1 / 2$ & $0 / 8$ & $0 / 6$ & $0 / 8$ & $0 / 5$ & $0 / 8$ & $0 / 6$ \\
\hline Lead, TR & $* 0 / 6$ & $* 0 / 2$ & $* 0 / 8$ & $* 0 / 6$ & $*_{1 / 8}$ & $* 0 / 5$ & $* 0 / 8$ & $* 0 / 6$ \\
\hline Mercury, TR & $0 / 5$ & $0 / 2$ & $0 / 8$ & $0 \Pi$ & $0 / 8$ & $0 / 5$ & $1 / 9$ & $0 / 7$ \\
\hline Selenium, TR & $0 / 6$ & $0 / 2$ & $0 / 8$ & $0 / 6$ & $5 / 8$ & $2 / 5$ & $0 / 8$ & $0 / 6$ \\
\hline \multicolumn{9}{|c|}{ SECONDARY STANDARDS } \\
\hline $\mathrm{pH}(\min )$ & $1 / 6$ & $3 / 6$ & $0 / 8$ & $1 / 8$ & $0 / 8$ & $1 / 8$ & $0 / 9$ & $1 / 9$ \\
\hline $\mathrm{pH}(\max )$ & $1 / 6$ & $0 / 6$ & $1 / 8$ & $1 / 8$ & $0 / 8$ & $0 / 8$ & $2 / 9$ & $0 / 9$ \\
\hline Dissolved oxygen & $0 / 6$ & $6 / 6$ & $0 / 8$ & $8 / 8$ & $0 / 8$ & $8 / 8$ & $0 / 9$ & $9 / 9$ \\
\hline Hardness, as $\mathrm{CaCO}_{3}$ & $2 / 6$ & $0 / 2$ & $8 / 8$ & $7 \Pi$ & $8 / 8$ & $5 / 5$ & $7 / 9$ & $6 / 7$ \\
\hline Sulfate, dissolved & $1 / 6$ & $0 / 2$ & $4 / 8$ & $5 \pi$ & $7 / 8$ & $5 / 5$ & $3 / 9$ & $5 / 7$ \\
\hline Chloride, dissolved & $0 / 6$ & $0 / 2$ & $0 / 8$ & $0 \sqcap$ & $0 / 8$ & $0 / 5$ & $0 / 9$ & $0 / 7$ \\
\hline Dissolved solids & $1 / 6$ & $0 / 2$ & $4 / 8$ & $6 \Pi$ & $7 / 8$ & $5 / 5$ & $3 / 9$ & $4 / 7$ \\
\hline Specific conductance & $1 / 6$ & $1 / 6$ & $4 / 8$ & $6 / 8$ & $7 / 8$ & $7 / 8$ & $4 / 9$ & $6 / 9$ \\
\hline Ammonia, dissolved & $0 / 4$ & $2 / 4$ & $0 / 8$ & $7 / 8$ & $0 / 8$ & $1 / 3$ & $1 / 8$ & $3 / 6$ \\
\hline Copper, TR & $0 / 6$ & $0 / 2$ & $0 / 8$ & $0 / 6$ & $0 / 8$ & $0 / 5$ & $0 / 8$ & $0 / 6$ \\
\hline Iron, TR & $4 / 6$ & $2 / 2$ & $2 / 8$ & $6 / 6$ & $3 / 8$ & $3 / 5$ & $4 / 8$ & $5 / 6$ \\
\hline Manganese, TR & $4 / 6$ & $2 / 2$ & $3 / 8$ & $6 / 6$ & $5 / 8$ & $5 / 5$ & $3 / 8$ & $6 / 6$ \\
\hline Zinc, TR & $0 / 6$ & $0 / 2$ & $0 / 8$ & $0 / 6$ & $0 / 8$ & $0 / 5$ & $0 / 8$ & $0 / 6$ \\
\hline \multicolumn{9}{|l|}{ Phytoplankton: } \\
\hline Anabaena & $1 / 6$ & NA & $1 / 8$ & NA & $0 / 8$ & NA & $2 / 9$ & NA \\
\hline Chlamydomonas & $2 / 6$ & NA & $0 / 8$ & NA & $3 / 8$ & NA & $0 / 9$ & NA \\
\hline Dinobryon & $1 / 6$ & NA & $0 / 8$ & NA & $1 / 8$ & NA & $0 / 9$ & NA \\
\hline
\end{tabular}

concentrations less than the criterion. A water sample from the hypolimnion of one control pond had a total chromium concentration of $130 \mu \mathrm{g} / \mathrm{L}$ that exceeded the MCL of $100 \mu \mathrm{g} / \mathrm{L}$.

Water samples from the epilimnion of all 31 ponds exceeded one or more SMCL's. Water samples from 27 of these exceeded two SMCL's, including cri- teria for $\mathrm{pH}$, phytoplankton, and hardness, which are easily treatable.

Water samples from all ponds had $\mathrm{pH}$ values within the recommended range for $\mathrm{pH}$ somewhere in the water column. The $\mathrm{pH}$ often changes with depth, so it is possible for a pond to be outside the range for $\mathrm{pH}$ somewhere in the water column, but be within the range 
elsewhere in the water column. The $\mathrm{pH}$ was measured at depth increments, so changes in $\mathrm{pH}$ were noted. Water from six ponds did not meet the minimum $\mathrm{pH}$ of 6.5 somewhere in the water column and water from five ponds exceeded the maximum $\mathrm{pH}$ of 8.5 somewhere in the water column. When the median $\mathrm{pH}$ was used, water in all of the ponds had $\mathrm{pH}$ values within the recommended range.

Hardness concentrations in water samples from the epilimnion of 25 of 31 ponds exceeded the criterion of $100 \mathrm{mg} / \mathrm{L}$. Applying the commonly used hardness chart (table 4), water with hardnesses greater than 100 $\mathrm{mg} / \mathrm{L}$ are classified as moderately hard or harder. Water samples from 4 of 6 control ponds and 2 of $9 \mathrm{McA}$ lester ponds had hardnesses of less than $75 \mathrm{mg} / \mathrm{L}$, which is classified as soft water. The mean hardness for samples from the six control ponds was $100 \mathrm{mg} / \mathrm{L}$, compared to mean hardnesses of 370,940 , and 200 $\mathrm{mg} / \mathrm{L}$ for samples from Croweburg, Iron Post, and McAlester ponds.

None of the water samples contained dissolvedchloride concentrations in excess of the SMCL of 250 $\mathrm{mg} / \mathrm{L}$. Water samples from the epilimnion of 15 of 31 ponds had dissolved sulfate concentrations in excess of the SMCL of $250 \mathrm{mg} / \mathrm{L}$. Large dissolved-sulfate concentrations are common in water from ponds formed by strip mining. Water samples from the epilimnion of 4 of 8 Croweburg ponds, 7 of 8 Iron Post ponds, and 3 of 9 McAlester ponds contained sulfate concentrations greater than the SMCL, with maximum concentrations ranging from 270 to $1,800 \mathrm{mg} / \mathrm{L}$ (table 12). Dissolved sulfate concentrations in a water sample from one of the six control ponds exceeded the SMCL, with a maximum concentration of $390 \mathrm{mg} / \mathrm{L}$ (table 12, at back of report). Sulfate concentrations in water samples from the hypolimnion of 15 of 21 ponds exceeded the SMCL.

Water in the epilimnion of 15 ponds had concentrations exceeding the SMCL for dissolved solids. A limit of $500 \mathrm{mg} / \mathrm{L}$ is the recommended maximum concentration for dissolved solids unless more suitable supplies are unavailable. Dissolved-solids concentrations in water samples from control ponds exceeded the dissolved-solids criterion the least often, and concentrations in water samples from Iron Post ponds exceeded this criterion the most often. Water samples from 1 of 6 control ponds had total dissolved-solids concentrations exceeding the criterion with a maximum dissolved-solids concentration of $616 \mathrm{mg} / \mathrm{L}$ (table 12). Water samples from 7 of 8 Iron Post ponds contained dissolved-solids concentrations ranging from 890 to $3030 \mathrm{mg} / \mathrm{L}$ (table 12). Water samples from the hypolimnion of all the ponds exceeded one or more SMCL's.
The ammonia concentration in a water sample from the epilimnion of one pond exceeded the ammonia criterion of $0.5 \mathrm{mg} / \mathrm{L}$, with a concentration of 0.95 $\mathrm{mg} / \mathrm{L}$ of dissolved ammonia (table 13). Ammonia concentrations in water samples from the hypolimnion of 13 of 21 ponds exceeded the criterion, with concentrations ranging from 0.52 to $6.7 \mathrm{mg} / \mathrm{L}$ (table 13, at back of report). Water samples from Croweburg ponds were the most likely to exceed the criterion. Water samples from 7 of 8 ponds exceeded the criterion.

Water samples from the epilimnion of 13 of 31 ponds contained total recoverable iron in excess of the SMCL of $0.3 \mathrm{mg} / \mathrm{L}$ and water samples from the epilimnion of 15 of 31 ponds contained total recoverable manganese in excess of the SMCL of $0.05 \mathrm{mg} / \mathrm{L}$. The concentrations of total recoverable iron and manganese in the water samples exceeding the criteria ranged from 0.31 to $1.7 \mathrm{mg} / \mathrm{l}$ and 0.07 to $0.84 \mathrm{mg} / \mathrm{L}$ (table 14). Control ponds had the highest percentage of ponds with samples from the epilimnion exceeding the criteria. Samples from 4 of 6 control ponds exceeded the criteria for both iron and manganese, with concentrations ranging from 0.4 to $1.5 \mathrm{mg} / \mathrm{L}$ and 0.1 to $0.84 \mathrm{mg} / \mathrm{L}$ (table 14). Croweburg ponds had the smallest percentage of ponds with water samples exceeding the criteria. Samples from 2 of 8 ponds exceeded the iron criterion, and samples from 3 of 8 ponds exceeded the manganese in the epilimnion. A greater percentage of water samples from the hypolimnion contained iron and manganese concentrations in excess of the criteria. Water samples from the hypolimnion of 16 of 19 ponds contained iron concentrations in excess of the criterion. All of the ponds sampled in the hypolimnion contain water with manganese concentrations exceeding the criterion. Concentrations ranged from 3.3 to $34 \mathrm{mg} / \mathrm{L}$ of iron and 0.4 to $23 \mathrm{mg} / \mathrm{L}$ of manganese (table 14 , at back of report).

Water samples from 1 of 6 control ponds had populations of Anabaena and Dinobryon in excess of the criteria of 600 and 500 cells per $\mathrm{mL}$, and samples from 2 of 6 control ponds had populations of Chlamydomonas in excess of the criterion of 10 cells per $\mathrm{mL}$. Water samples from three Iron Post ponds exceeded the criteria for Chlamydomonas, and water from one Iron Post pond exceeded the criteria for Dinobryon. Water samples from two McAlester ponds and one Croweburg pond had algal populations in excess of the criteria for Anabaena. None of the water samples contained populations of Aphanizomenon, Crypotomonas, Synura, or Uregenopsis in excess of the criteria. 
Table 15. Water-quality criteria for the protection of aquatic life [* See tables 2 and 3 in text; $\mathrm{mg} / \mathrm{L}$, milligrams per liter, $\mu \mathrm{g} / \mathrm{L}$, micrograms per liter; ${ }^{\circ} \mathrm{C}$, degrees Celsius; min, minimum; max, maximum; TR, total recoverable; EPA, U.S. Environmental Protection Agency; ln (hardness), natural log of carbonate hardness in milligrams per liter; where applicable the fourday average concentration was used as the criterion]

\begin{tabular}{lcc}
\hline \multicolumn{1}{c}{ Constituent } & Water-quallty criteria & Source \\
\hline $\mathrm{pH}$ & $6.5-9.0$ & OWRB (1985) \\
Temperature (spring) & $20^{\circ} \mathrm{C} *$ & EPA (1986a) \\
Temperature (summer) & $30^{\circ} \mathrm{C} *$ & EPA (1986a) \\
Dissolved oxygen & $5.0 \mathrm{mg} / \mathrm{L}(\mathrm{min})$ & EPA (1986a) \\
Alkalinity, total as $\mathrm{CaCO}_{3}$ & $20 \mathrm{mg} / \mathrm{L}(\mathrm{min})$ & EPA (1986a) \\
Dissolved solids & $5,000 \mathrm{mg} / \mathrm{L}$ & McKee and Wolf \\
& & $1963)$ \\
Specific conductance & $6,700 \mathrm{mS} / \mathrm{cm}$ & See text \\
Nitrate, dissolved & $90 \mathrm{mg} / \mathrm{L}$ & EPA (1986a) \\
Nitrite, dissolved & $5 \mathrm{mg} / \mathrm{L}$ & EPA (1986a) \\
Ammonia, dissolved & $5 e$ table 6 & EPA (1986a) \\
Arsenic & $0.19 \mathrm{mg} / \mathrm{L}$ & EPA (1986a) \\
Cadmium, TR & $11 \mathrm{mg} / \mathrm{L}$ & EPA (1986a) \\
Chromium (VI), TR & $e(0.7852[\ln (\mathrm{hardness})]-3.49) \mathrm{mg} / \mathrm{L}$ & EPA (1986a) \\
Chromium (III), TR & $\mathrm{e}(0.8190[\ln (\mathrm{hardness})]+1.561) \mathrm{mg} / \mathrm{L}$ & EPA (1986a) \\
Copper, TR & $\mathrm{e}(0.8545[\ln (\mathrm{hardness})]-1.465) \mathrm{mg} / \mathrm{L}$ & EPA (1986a) \\
Iron, TR & $1.0 \mathrm{mg} / \mathrm{L}$ & EPA (1986a) \\
Lead, TR & $\mathrm{e}(1.273[\ln (\mathrm{hardness})]-4.705) \mathrm{mg} / \mathrm{L}$ & EPA (1986a) \\
Mercury, TR & $0.012 \mathrm{mg} / \mathrm{L}$ & EPA (1986a) \\
Selenium, TR & $0.035 \mathrm{mg} / \mathrm{L}(24-\mathrm{hr} . \mathrm{ave})$ & EPA (1986a) \\
Zinc, TR & EPA (1987) \\
\hline
\end{tabular}

\section{Aquatic Life}

Aquatic life is particularly sensitive to the dissolved constituents in a pond. A large response variation exists among aquatic organisms. Different aquatic organisms do not exhibit the same degree of susceptibility to a given concentration of toxicant. When establishing a criterion, the response of the more sensitive species was used where possible. Water-quality standards set by the U.S. Environmental Protection Agency (1986a) are not intended to offer the same degree of safety for survival and propagation at all times to all organisms within a given ecosystem. Therefore, not all species are protected by these criteria. The criteria for the protection of aquatic life are given in table 15.

The criteria for five constituents are functions of hardness. Therefore, each pond has its own unique criteria for these constituents. It is possible for one pond to exceed a criterion and another to be within the limit, yet both have the same concentration of a constituent. Table 16 shows those constituents with criteria that are dependent on hardness and the associated values for various levels of hardness. The comparison of the water-quality data from the ponds to the water-quality criteria for the protection of aquatic life is given in table 17.

Water from 25 of the ponds had $\mathrm{pH}$ values within the recommended range in either the epilimnion or hypolimnion or both. Of the six ponds containing water with minimum $\mathrm{pH}$ 's below the recommended minimum of 6.5 , all had water with $\mathrm{pH}$ values within .7 units of 6.5 (table 10). In five of these ponds, the $\mathrm{pH}$ dropped below the minimum in the hypolimnion only. When the median $\mathrm{pH}$ per site per pond is used, water from sites on three ponds were below the minimum $\mathrm{pH}$. One control pond contained water with a $\mathrm{pH}$ above the maximum of 
9.0. This pond was sampled during an algal bloom and the elevated $\mathrm{pH}$ was probably caused by increased photosynthesis. Photosynthesis affects the amount of oxygen and carbon dioxide dissolved in the water which in turn affects the $\mathrm{pH}$ (Hem, 1985). ponds, one was a McAlester pond, and one was a Croweburg pond. The concentration of alkalinity in ponds not meeting the criterion ranged from 5 to 18 $\mathrm{mg} / \mathrm{L}$ (table 12).

All the ponds met the dissolved nitrate and nitrite criteria for the protection of aquatic life. Ammo-

Table 16. Water-quality criteria for the protection of aquatic life that are dependent on hardness [All concentrations in micrograms per liter]

\begin{tabular}{lccccccc}
\hline \multirow{2}{*}{$\begin{array}{c}\text { Total recoverable } \\
\text { trace element }\end{array}$} & 50 & 100 & 200 & 300 & 400 & 500 & 1,000 \\
\cline { 2 - 8 } & .66 & 1.1 & 2.0 & 2.7 & 3.4 & 4.0 & 6.9 \\
\hline Cadmium & 120 & 210 & 360 & 510 & 640 & 770 & 1,400 \\
Chromium & 6.5 & 12 & 21 & 30 & 39 & 47 & 85 \\
Copper & 1.3 & 3.2 & 7.7 & 13 & 19 & 25 & 60 \\
Lead & 59 & 110 & 190 & 270 & 340 & 410 & 750 \\
\hline Zinc & & & & & & & \\
\hline
\end{tabular}

Temperature data from vertical profiles were used to compare with the criterion (table 10). The criterion requires that the temperature be equal or less than $20.0^{\circ} \mathrm{C}$ during the spring and $30.0^{\circ} \mathrm{C}$ during the summer at some point in the epilimnion where the dissolved oxygen is greater than $5 \mathrm{mg} / \mathrm{L}$. Water samples from all the ponds met the criterion for protection of spawning during the spring. Most of the ponds had temperatures less than the criterion somewhere in the epilimnion when sampled in the summer. Two control ponds, one Croweburg pond, and three McAlester ponds exceeded the criterion in the summer.

Dissolved-oxygen levels are regulated by the State for streams but not for ponds or lakes. This criterion for streams of $5.0 \mathrm{mg} / \mathrm{L}$ of dissolved oxygen is used in this report. Water from all of the ponds had sufficient dissolved oxygen in the epilimnion to sustain aquatic life. All ponds had dissolved oxygen levels in the hypolimnion less than the criterion for the protection of aquatic life (table 10). These low values usually were found during summer sampling. Fish could survive by staying in the epilimnion. However, low dissolved-oxygen levels in the hypolimnion decrease the available habitat for fish, affect the type and number of benthic invertebrates, and may cause low dissolved-oxygen levels in the fall during turnover.

Alkalinities from water samples from 4 of 31 ponds were below the recommended minimum concentration of $20 \mathrm{mg} / \mathrm{L}$. Two of these ponds were control nia concentrations of a water sample from the epilimnion of one McAlester pond exceeded the criterion. Dissolved ammonia concentrations in water samples from the hypolimnion of one control pond, two Croweburg ponds and three McAlester ponds exceeded the criterion (table 7). The ponds were sampled for nutrients in the summer.

Water samples from 26 ponds exceeded one or more trace element criteria either in the epilimnion, hypolimnion, or both. Water samples from 16 ponds exceeded one or more trace-element criteria in the epilimnion. Water samples from 9 of these ponds exceeded one trace-element criterion and 6 exceeded two criteria. Total recoverable mercury criterion was exceeded the most often. Total mercury concentrations in water samples from the epilimnion of 12 of 31 ponds and the hypolimnion of 15 of 21 ponds exceeded the mercury criterion of $0.012 \mu \mathrm{g} / \mathrm{L}$. These ponds had mercury in excess of the detection limit of $0.5 \mu \mathrm{g} / \mathrm{L}$ in the spring and $0.1 \mu \mathrm{g} / \mathrm{L}$ in the summer. Water samples from the other ponds had mercury levels below the detection limit, which is greater than the criterion. Total cadmium concentration in water samples from the epilimnion of five ponds exceeded the calculated criterion. Water samples from three more ponds had concentrations less than the detection limit, which was higher than the calculated criterion. Water samples from all except one pond had total recoverable copper concentrations below the calculated criterion. 
Table 17. Comparison of pond-water quality to water-quality criteria for the protection of aquatic life [min, minimum; max, maximum; *, detection limit is higher than the criterion for some or all samples; NA, not applicable; TR, total recoverable. The fraction used is the number of ponds exceeding the criterion over the total number of ponds with data; shallow samples were collected from the epilimnion; deep samples were collected from the hypolimnion]

\begin{tabular}{lcccccccc}
\hline & \multicolumn{7}{c}{ Pond type and locatlon of sample } \\
\cline { 2 - 8 } \multicolumn{1}{c}{ Varlable } & \multicolumn{2}{c}{ Control } & \multicolumn{2}{c}{ Croweburg } & Iron Post & \multicolumn{2}{c}{ McAlestor } \\
\cline { 2 - 8 } & Shallow & Doep & Shallow & Doop & Shallow & Doep & Shallow & Doop \\
\hline $\mathrm{pH}$ (min) & $1 / 6$ & $3 / 6$ & $0 / 8$ & $1 / 8$ & $0 / 8$ & $1 / 8$ & $0 / 9$ & $1 / 9$ \\
$\mathrm{pH}$ (max) & $1 / 6$ & $0 / 6$ & $0 / 8$ & $0 / 8$ & $0 / 8$ & $0 / 8$ & $0 / 9$ & $0 / 9$ \\
Temperature (spring) & $0 / 6$ & $\mathrm{NA}$ & $0 / 8$ & NA & $0 / 8$ & NA & $0 / 9$ & NA \\
Temperature (summer) & $2 / 6$ & NA & $1 / 8$ & NA & $0 / 8$ & NA & $3 / 9$ & NA \\
Dissolved oxygen & $0 / 6$ & $6 / 6$ & $0 / 8$ & $8 / 8$ & $0 / 8$ & $8 / 8$ & $0 / 9$ & $9 / 9$ \\
Alkalinity & $2 / 6$ & $2 / 2$ & $1 / 8$ & $0 / 7$ & $0 / 8$ & $0 / 5$ & $1 / 9$ & $0 / 7$ \\
Dissolved solids & $0 / 6$ & $0 / 2$ & $0 / 8$ & $0 / 7$ & $0 / 8$ & $0 / 5$ & $0 / 9$ & $0 / 9$ \\
Specific conductance & $0 / 6$ & $0 / 6$ & $0 / 8$ & $0 / 8$ & $0 / 8$ & $0 / 8$ & $0 / 9$ & $0 / 9$ \\
Nitrate, dissolved & $0 / 4$ & $0 / 4$ & $0 / 8$ & $0 / 8$ & $0 / 8$ & $0 / 3$ & $0 / 8$ & $0 / 5$ \\
Nitrite, dissolved & $0 / 4$ & $0 / 4$ & $0 / 8$ & $0 / 8$ & $0 / 8$ & $0 / 3$ & $0 / 8$ & $0 / 5$ \\
Ammonia, dissolved & $0 / 4$ & $1 / 4$ & $0 / 8$ & $3 / 8$ & $0 / 8$ & $0 / 3$ & $1 / 8$ & $2 / 6$ \\
Arsenic, TR & $0 / 6$ & $0 / 2$ & $0 / 8$ & $0 / 6$ & $0 / 8$ & $0 / 5$ & $0 / 8$ & $0 / 6$ \\
Cadmium, TR & $* 2 / 6$ & $* 1 / 2$ & $1 / 8$ & $0 / 6$ & $1 / 8$ & $1 / 5$ & $1 / 8$ & $0 / 6$ \\
Chromium, TR & $0 / 6$ & $0 / 2$ & $0 / 8$ & $0 / 6$ & $0 / 8$ & $0 / 5$ & $0 / 8$ & $0 / 6$ \\
Copper, TR & $* 1 / 6$ & $* 1 / 2$ & $* 0 / 8$ & $0 / 6$ & $0 / 8$ & $0 / 5$ & $* 0 / 8$ & $* 0 / 6$ \\
Iron, TR & $1 / 6$ & $2 / 2$ & $1 / 8$ & $4 / 6$ & $1 / 8$ & $2 / 5$ & $2 / 8$ & $3 / 6$ \\
Lead, TR & $* 0 / 6$ & $* 0 / 2$ & $* 0 / 8$ & $* 0 / 6$ & $* 1 / 4$ & $* 0 / 5$ & $* 0 / 8$ & $* 0 / 6$ \\
Mercury, TR & $* 3 / 5$ & $2 / 2$ & $* 1 / 8$ & $7 / 8$ & $* 3 / 8$ & $* 2 / 5$ & $* 5 / 9$ & $* 6 / 8$ \\
Selenium, TR & $0 / 6$ & $0 / 2$ & $0 / 8$ & $0 / 6$ & $1 / 8$ & $0 / 5$ & $0 / 8$ & $0 / 6$ \\
Zinc, TR & $0 / 6$ & $0 / 2$ & $0 / 8$ & $0 / 6$ & $0 / 8$ & $0 / 5$ & $0 / 8$ & $0 / 6$ \\
\hline
\end{tabular}

For water samples from nine of these ponds the detection limit is greater than the calculated criterion (table 16). Five of these were control ponds. Total iron concentration in water samples from the epilimnion of five ponds exceeded the criterion for iron of $1 \mathrm{mg} / \mathrm{L}$, with iron concentrations ranging from 1.2 to $1.7 \mathrm{mg} / \mathrm{L}$. Total iron concentrations in water samples from the hypolimnion of 11 ponds exceeded the criterion, with concentrations ranging from $1.1 \mathrm{mg} / \mathrm{L}$ to $34 \mathrm{mg} / \mathrm{L}$ (table 12). Water samples from 30 ponds had total recoverable lead concentrations below the analytical detection limit of $0.1 \mathrm{mg} / \mathrm{L}$. In most instances the detection limit is greater than the calculated criterion (table 16). Water samples from all ponds had total recoverable chromium and zinc concentrations less than the criteria.

Water samples from one control pond had large phytoplankton populations that may be detrimental to fish. The dissolved-oxygen concentration below the layer containing the algal bloom was less than 5.0 $\mathrm{mg} / \mathrm{L}$. Algal blooms on other ponds may have been missed, because of sample timing.

Balanced phytoplankton and benthic invertebrate communities are essential for fish survival and growth. The phytoplankton concentrations in water samples from ponds sampled during the summer of 1985 ranged from 790 cells per $\mathrm{mL}$ at a site on an Iron Post pond to 291,300 cells per $\mathrm{mL}$ at a site on a control 
pond (table 18, at back of report). The concentration of phytoplankton and benthic invertebrates varied widely from pond to pond. The mean concentration of phytoplankton in the six control ponds ranged from 5,130 to 173,500 cells per $\mathrm{mL}$. The concentration of phytoplankton from site to site within a pond varied widely. The concentration from sites in Control Pond 2

\section{Waterfowl Habitat}

Aquatic habitats in eastern Oklahoma, part of the Easterm Plains corridor of the Central flyway (Bellrose, 1976), are heavily utilized during the winter and migration periods by loons, grebes, pelicans, geese, ducks, gulls, and shore birds. The most abundant win-

Table 20. Water-quality criteria for the protection of waterfowl

[mg/L, milligrams per liter, min, minimum; max, maximum; ${ }^{\circ} \mathrm{C}$, degrees Celsius; TR, total recoverable; $>$, greater than; NAS/NAE, National Academy of Sciences and National Academy of Engineering; EPA, U.S. Environmental Protection Agency]

\begin{tabular}{lcl}
\hline \multicolumn{1}{c}{ Constituent } & Water-quality criterla & \multicolumn{1}{c}{ Source } \\
\hline $\mathrm{pH}$ & $7.0-9.2, \mathrm{~min}-\mathrm{max}$ & NAS/NAE (1973) \\
Temperature & $21^{\circ} \mathrm{C}$ & NAS/NAE (1973) \\
Dissolved oxygen & $>0.5$ & See text \\
Alkalinity, bicarbonate & $25 \mathrm{mg} / \mathrm{L} \mathrm{min}$ & EPA (1986a) \\
Selenium, TR & $.002 \mathrm{mg} / \mathrm{L}$ & Brown (1987) \\
\hline
\end{tabular}

varied from 3,600 to 291,300 cells per $\mathrm{mL}$. The mean benthic invertebrate population ranged from 120 organisms per $\mathrm{m}^{2}$ to 4,310 organisms per $\mathrm{m}^{2}$ (table 19 , at back of report). It is difficult to relate the phytoplankton or benthic invertebrate population size to suitability for fish habitat, because of sample variability and interrelationships between phytoplankton and vertebrates and invertebrates. A low total phytoplankton count may indicate heavy utilization by vertebrates and invertebrates.

The number of phytoplankton genera found in pond water samples ranged from 2 per pond to 18 per pond. A larger number of genera may indicate a more diverse phytoplankton population, which may support a more diverse population of invertebrates and vertebrates. The total number of benthic invertebrate genera found ranged from 2 to 30 per pond (table 19).

Macrophytes are a source of food and habitat for invertebrates and fish. The control ponds sampled were observed to have a higher percentage of macrophytes per area of pond. Many of the older ponds formed by strip mining were observed to have more macrophytes than the younger ponds. Many of the older ponds had shallow arms where macrophytes could grow. Macrophyte populations were not measured, so no conclusions can be drawn about macrophyte growth and a pond's suitability. tering species in eastem Oklahoma are mallards, gadwalls, common mergansers, and American coots (Schnell and others, 1979). The mallard population, estimated at 160,000 in 1968 , winter on artificial reservoirs in Oklahoma (Bellrose, 1968). Most species of dabbling duck use winter habitat for more than 7 months. Conditions on the wintering grounds can influence the welfare of birds using them and also the breeding condition of birds departing from them in the spring (Chabbreck, 1979).

The water-quality criteria for the protection of waterfowl are often the criteria applicable to the growth of plants and invertebrates utilized by waterfowl, rather than the criteria for ingestion of water by waterfowl. The water-quality criteria for protection of waterfowl are given in table 20.

The comparison of the water-quality data from the ponds to the water-quality criteria is given in table 21 .

Water depth is a possible criteria that is not listed in the table. The type of duck (diving or dabbling) and the species of duck affect the applicability of a depth criterion. However, depth does need to be considered when discussing the suitability of a water body for use by waterfowl. The depth of the water affects the type and amount of edible vegetation. Too much or too little may affect food availability. A lake in central Louisiana was reported to have tremendous concentrations of most species during the fall and early winter when depths were less than $0.5 \mathrm{~m}(1.6 \mathrm{ft})$ and favorable for feeding. Deeper flooding in late winter caused most 
Table 21. Comparison of pond-water quality to water-quality criteria for the protection of waterfowl

[max, maximum; min, minimum; NA, not applicable; *, detection limit is higher than the criterion for some or all samples; TR, total recoverable. The fraction used is the number of ponds exceeding the criterion over the total number of ponds with data; shallow samples were collected from the epilimnion; deep samples were collected from the hypolimnion]

\begin{tabular}{|c|c|c|c|c|c|c|c|c|}
\hline \multirow{3}{*}{ Varlable } & \multicolumn{8}{|c|}{ Pond type and locatlon of sample } \\
\hline & \multicolumn{2}{|c|}{ Control } & \multicolumn{2}{|c|}{ Croweburg } & \multicolumn{2}{|c|}{ Iron Post } & \multicolumn{2}{|c|}{ McAlester } \\
\hline & Shallow & Deep & Shallow & Deep & Shallow & Deep & Shallow & Deep \\
\hline $\mathrm{pH}(\min )$ & $4 / 6$ & NA & $0 / 8$ & NA & $0 / 8$ & NA & $2 / 9$ & NA \\
\hline $\mathrm{pH}(\max )$ & $1 / 6$ & NA & $0 / 8$ & NA & $0 / 8$ & NA & $0 / 9$ & NA \\
\hline Temperature & $6 / 6$ & $0 / 6$ & $8 / 8$ & $0 / 8$ & $8 / 8$ & $0 / 8$ & $9 / 9$ & $0 / 9$ \\
\hline Dissolved oxygen & $0 / 6$ & $5 / 6$ & $0 / 8$ & $6 / 8$ & $0 / 8$ & $4 / 8$ & $0 / 9$ & $5 / 9$ \\
\hline Alkalinity (min) & $2 / 6$ & $0 / 2$ & $1 / 8$ & $0 / 7$ & $0 / 8$ & $0 / 5$ & $1 / 9$ & $1 / 7$ \\
\hline Selenium, TR & $* / 6$ & $* / 2$ & $* / 8$ & $* / 6$ & $* 5 / 8$ & $* 2 / 5$ & $* / 9$ & $* / 6$ \\
\hline
\end{tabular}

dabbling ducks to abandon the area (Chabbreck, 1979). Diving ducks, which feed on invertebrates, will tolerate deeper depths (Michael J. Johnson, oral commun., 1990). Deeper ponds may be utilized by dabbling ducks for resting. Mallards and pintail often use lakes in Oklahoma as resting areas, and feed in nearby fields (Chabbreck, 1979).

All of the ponds in the study are deeper than 1.6 $\mathrm{ft}$ (table 12). Farm ponds in the area may be shallower, but were not used for the study, because depth was a consideration in control-pond selection. Many of the ponds, both control and strip mine, have areas shallower than $1.6 \mathrm{ft}$, with considerable macrophyte growth. The older ponds formed by strip mining had more shallow areas than newer ponds. The Iron Post sedimentation ponds had more shallow areas and more macrophyte growth than the last-cut ponds formed by strip mining.

Data from the epilimnion were used to compare $\mathrm{pH}$ values, because the $\mathrm{pH}$ criterion is protective of plants utilized by waterfowl. Water from all of the ponds except for one control pond met the criterion for maximum $\mathrm{pH}$ of 9.2. This criterion was exceeded in the summer only. Water samples from six ponds had $\mathrm{pH}$ levels less than the suggested minimum $\mathrm{pH}$ of 7.0. Four of the six ponds were control ponds and two were McAlester ponds. Two of the control ponds had $\mathrm{pH}$ levels less than the criterion in the summer only. Most water from ponds formed by strip mining had $\mathrm{pH}$ values within the recommended range. However, the ponds formed by strip mining tend to have a lower per- centage of littoral zone and therefore less area available for macrophyte growth than the control ponds.

The temperature criterion of $20^{\circ} \mathrm{C}$ was exceeded in all of the ponds during the summer sampling. Water in all ponds met the temperature criterion during the spring, and probably would meet the criterion during the winter months when the ponds are heavily utilized by waterfowl.

Dissolved-oxygen levels were $0.5 \mathrm{mg} / \mathrm{L}$ or less in the water column in 21 of the 31 ponds, usually at or near the bottom. In many of these ponds a hydrogen sulfide odor, which indicates anaerobic conditions, was detected when water samples were collected from the bottom of the pond. The largest percentage of ponds with low dissolved-oxygen concentrations in the water column were control ponds. The smallest percentage were Iron Post. The low dissolved-oxygen concentrations occurred in the summer when few wild waterfowl are present. Therefore, these findings are not as applicable to wintering and migration habitat.

Water samples from 22 ponds meet the criteria for alkalinity and selenium. Twenty ponds meet the criteria in the spring. Water samples from 4 of the 31 ponds had minimum alkalinities in the epilimnion that were less than the recommended criterion of $25 \mathrm{mg} / \mathrm{L}$. Two of these were from control ponds. Alkalinities of water samples from one Croweburg pond and one McAlester pond also exceeded the criterion of minimum alkalinity. Water samples from these ponds had alkalinities ranging from 5 to $18 \mathrm{mg} / \mathrm{L}$ (table 12). Five Iron Post ponds exceeded the criterion for selenium of $2 \mu \mathrm{g} / \mathrm{L}$ with concentrations ranging from 11 to $78 \mu \mathrm{g} / \mathrm{L}$ (table 14). 


\section{Llvestock Watering}

The major types of livestock raised in Eastern Oklahoma are milk cows, beef cattle, hogs, and chickens (Oklahoma Water Resources Board, 1970 and 1971). Stock watering is probably the largest use of strip-mine pond water in Oklahoma. The toxicity of any element may render a pond undesirable for stock watering. The concentration at which an element is toxic depends upon the age, sex, species, physiological state of the animals, water intake, diet and its composition, the chemical form of the element, and the temperature of the water.

The water-quality criteria for the protection of livestock are shown in table 22 . The comparison of the water-quality data from the ponds to the water-quality criteria is given in table 23 .

Table 22. Water-quality criteria for the protection of livestock $[\mathrm{mg} / \mathrm{L}$, milligrams per liter, TR, total recoverable; $\mu \mathrm{S} / \mathrm{cm}$, microsiemens per centimeter, NAS/NAE, National Academy of Sciences and National Academy of Engineering]

\begin{tabular}{|c|c|c|}
\hline Constituent & Water-quality criterla & Source \\
\hline Sulfate, dissolved & $2500 \mathrm{mg} / \mathrm{L}$ & Ferreira, 1984 \\
\hline \multirow[t]{2}{*}{ Dissolved solids } & $2,860 \mathrm{mg} / \mathrm{L}$ (low tolerance) & McKee and Wolf, \\
\hline & $12,900 \mathrm{mg} / \mathrm{L}$ (high tolerance) & 1963 \\
\hline \multirow[t]{2}{*}{ Specific conductance } & $3,810 \mathrm{mS} / \mathrm{cm}$ (low tolerance) & See text \\
\hline & $17,200 \mathrm{mS} / \mathrm{cm}$ (high tolerance) & \\
\hline Nitrate plus nitrite, dissolved & $100 \mathrm{mg} / \mathrm{L}$ & NAS/NAE, 1973 \\
\hline Nitrite, dissolved & $10 \mathrm{mg} / \mathrm{L}$ & NAS/NAE, 1973 \\
\hline Aluminum, TR & $5 \mathrm{mg} / \mathrm{L}$ & NAS/NAE, 1973 \\
\hline Arsenic, TR & $0.2 \mathrm{mg} / \mathrm{L}$ & NAS/NAE, 1973 \\
\hline Boron, TR & $5.0 \mathrm{mg} / \mathrm{L}$ & NAS/NAE, 1973 \\
\hline Cadmium, TR & $.05 \mathrm{mg} / \mathrm{L}$ & NAS/NAE, 1973 \\
\hline Chromium, TR & $1.0 \mathrm{mg} / \mathrm{L}$ & NAS/NAE, 1973 \\
\hline Copper, TR & $0.5 \mathrm{mg} / \mathrm{L}$ & NAS/NAE, 1973 \\
\hline Lead, TR & $0.1 \mathrm{mg} / \mathrm{L}$ & NAS/NAE, 1973 \\
\hline Mercury, TR & $0.01 \mathrm{mg} / \mathrm{L}$ & NAS/NAE, 1973 \\
\hline Selenium, TR & $.05 \mathrm{mg} / \mathrm{l}$ & NAS/NAE, 1973 \\
\hline Zinc, TR & $25 \mathrm{mg} / \mathrm{L}$ & NAS/NAE, 1973 \\
\hline \multicolumn{2}{|c|}{ Presence of the following phytoplankton genera: } & $\begin{array}{l}\text { NAS/NAE, 1973; McKee and } \\
\text { Wolf, } 1963\end{array}$ \\
\hline \multicolumn{3}{|l|}{ Anacystis (Microcystis) } \\
\hline \multicolumn{3}{|l|}{ Aphanizomenon } \\
\hline \multicolumn{3}{|l|}{ Nostoc } \\
\hline \multicolumn{3}{|l|}{ Nodularia } \\
\hline \multicolumn{3}{|l|}{ Gloeotrichia } \\
\hline \multicolumn{3}{|l|}{ Gomphosphaeria } \\
\hline \multicolumn{3}{|l|}{ Anabaena } \\
\hline Coelosphaerium & & \\
\hline
\end{tabular}


Table 23. Comparison of pond-water quality to water-quality criteria for the protection of livestock [min, minimum; max, maximum; TDS, total dissolved solids; NA, not applicable; TR, total recoverable. The fraction used is the number of ponds exceeding the criterion over the total number of ponds with data; *. TDS criterion is used instead of the specific conductance criterion; shallow samples were collected from the epilimnion; deep samples were collected from the hypolimnion]

\begin{tabular}{|c|c|c|c|c|c|c|c|c|}
\hline \multirow{3}{*}{ Variable } & \multicolumn{8}{|c|}{ Pond type and location of sample } \\
\hline & \multicolumn{2}{|c|}{ Control } & \multicolumn{2}{|c|}{ Croweburg } & \multicolumn{2}{|c|}{ Iron Post } & \multicolumn{2}{|c|}{ McAlester } \\
\hline & Shallow & Deep & Shallow & Deep & Shallow & Deep & Shallow & Deep \\
\hline Sulfate, dissolved & $0 / 6$ & $0 / 2$ & $0 / 8$ & $0 / 7$ & $0 / 8$ & $0 / 5$ & $0 / 9$ & $0 / 7$ \\
\hline TDS (low tolerance) & $0 / 6$ & $0 / 2$ & $0 / 8$ & $2 / 7$ & $1 / 8$ & $1 / 5$ & $0 / 9$ & $1 / 7$ \\
\hline $\begin{array}{l}\text { Specific conductance } \\
\text { (low tolerance) }\end{array}$ & $* / 6$ & $0 / 6$ & $* / 8$ & $0 / 8$ & $* / 8$ & $1 / 8$ & $* / 9$ & $1 / 9$ \\
\hline TDS (high tolerance) & $0 / 6$ & $0 / 2$ & $0 / 8$ & $0 / 7$ & $0 / 8$ & $0 / 5$ & $0 / 9$ & $0 / 7$ \\
\hline $\begin{array}{l}\text { Specific conductance } \\
\text { (high tolerance) }\end{array}$ & $* / 6$ & $0 / 6$ & $* / 8$ & $0 / 8$ & $* / 8$ & $0 / 8$ & $* / 9$ & $0 / 9$ \\
\hline $\begin{array}{l}\text { Nitrate plus nitrite, } \\
\text { dissolved }\end{array}$ & $0 / 4$ & $0 / 4$ & $0 / 8$ & $0 / 8$ & $0 / 8$ & $0 / 3$ & $0 / 8$ & $0 / 5$ \\
\hline Nitrite, dissolved & $0 / 4$ & $0 / 4$ & $0 / 8$ & $0 / 8$ & $0 / 8$ & $O \beta$ & $0 / 8$ & $0 / 5$ \\
\hline Aluminum, TR & $0 / 6$ & $1 / 2$ & $0 / 8$ & $0 / 6$ & $0 / 8$ & $0 / 5$ & $0 / 8$ & $0 / 6$ \\
\hline Arsenic, TR & $0 / 6$ & $0 / 2$ & $0 / 8$ & $0 / 6$ & $0 / 8$ & $0 / 5$ & $0 / 8$ & $0 / 6$ \\
\hline Boron, TR & $0 / 6$ & $0 / 2$ & $0 / 8$ & $0 / 6$ & $0 / 8$ & $0 / 5$ & $0 / 8$ & $0 / 6$ \\
\hline Cadmium, TR & $0 / 6$ & $0 / 2$ & $0 / 8$ & $0 / 6$ & $0 / 8$ & $0 / 5$ & $0 / 8$ & $0 / 6$ \\
\hline Chromium, TR & $0 / 6$ & $0 / 2$ & $0 / 8$ & $0 / 6$ & $0 / 8$ & $0 / 5$ & $0 / 8$ & $0 / 6$ \\
\hline Copper, TR & $0 / 6$ & $0 / 2$ & $0 / 7$ & $0 / 6$ & $0 / 8$ & $0 / 5$ & $0 / 8$ & $0 / 6$ \\
\hline Lead, TR & $0 / 6$ & $0 / 2$ & $0 / 7$ & $0 / 6$ & $1 / 7$ & $0 / 5$ & $0 / 8$ & $0 / 6$ \\
\hline Mercury, TR? & $0 / 5$ & $0 / 2$ & $0 / 8$ & $0 / 7$ & $0 / 8$ & $0 / 5$ & $1 / 9$ & $0 / 7$ \\
\hline Selenium, TR & $0 / 6$ & $0 / 2$ & $0 / 8$ & $0 / 6$ & $1 / 8$ & $0 / 5$ & $0 / 8$ & $0 / 6$ \\
\hline Zinc, TR & $0 / 6$ & $0 / 2$ & $0 / 9$ & $0 / 6$ & $0 / 8$ & $0 / 5$ & $0 / 8$ & $0 / 6$ \\
\hline $\begin{array}{l}\text { Phytoplankton toxic } \\
\text { taxa present }\end{array}$ & $6 / 6$ & NA & $8 / 8$ & NA & $8 / 8$ & NA & $8 / 8$ & NA \\
\hline
\end{tabular}

Most of the ponds are well suited for livestock watering. Water samples from eight ponds exceeded one or more chemical criteria for the protection of livestock. Water samples from five of these ponds exceeded the criteria in the hypolimnion only. Maximum dissolved-solids concentrations in water samples from the epilimnion of one Iron Post pond exceeded the criterion for poultry watering of $2,860 \mathrm{mg} / \mathrm{L}$. Maximum dissolved-solids concentrations or corresponding specific conductances in water samples from the hypolimnion of five ponds formed by strip mining exceeded this criterion. This would be pertinent only if the stock water were pumped from the hypolimnion. The range for dissolved-solids concentrations exceeding the criterion in water samples from the hypolimnion was 2,930 to $3,760 \mathrm{mg} / \mathrm{L}$ (table 10 ). The dissolved solids and cor- responding specific-conductance criteria for other livestock species were met by all the ponds in both the epilimnion and hypolimnion.

Total recoverable cadmium, chromium, copper, and zinc concentration in water samples from all the ponds met the criteria. The lead concentration in a water sample from the epilimnion of one Iron Post pond exceeded the criterion of $0.1 \mathrm{mg} / \mathrm{L}$, and the mercury concentration in a water sample from the epilimnion of one McAlester pond exceeded the criterion of 0.01 $\mathrm{mg} / \mathrm{L}$. The aluminum concentration in a water sample from the hypolimnion of one control pond exceeded the criterion of $5 \mathrm{mg} / \mathrm{L}$.

Water samples from all the ponds had algal species present that are considered toxic to livestock. Wa- 
Table 24. Water-quality criteria for irrigation

[mg/L, milligrams/liter; $\mu \mathrm{S} / \mathrm{cm}$, microsiemens per centimeter, min, minimum; max, maximum; SAR, Sodium adsorption ratio; TR, total recoverable; EPA, U.S. Environmental Protection Agency; NAS/NAE,National Academy of Sciences and National Academy of Engineering; OWRB, Oklahoma Water Resources Board]

\begin{tabular}{lcl}
\hline \multicolumn{1}{c}{ Constituent } & Water-quallty crlterla & \multicolumn{1}{c}{ Source } \\
\hline pH & $4.5-9.0, \mathrm{~min}-\mathrm{max}$ & EPA, 1986a \\
SAR & 4 (sensitive crops) & EPA, 1986a \\
& 18 (tolerant crops) & \\
Dissolved solids & $500 \mathrm{mg} / \mathrm{L}$ (sensitive crops) & OWRB, 1985 \\
& $1,000 \mathrm{mg} / \mathrm{L}$ (semitolerant crops) & \\
Specific conductance & $2,000 \mathrm{mg} / \mathrm{L}$ (tolerant crops) & \\
Aluminum, TR & $670 ; 1330 ; 2,670 \mu$ S/cm & See text \\
Arsenic, TR & $5.0 \mathrm{mg} / \mathrm{L}$ & NAS/NAE, 1973 \\
Boron, TR & $0.10 \mathrm{mg} / \mathrm{L}$ & EPA, 1976b \\
& $0.75 \mathrm{mg} / \mathrm{L}$ & EPA, 1986a \\
& $($ sensitive crops) & \\
& $1 \mathrm{mg} / \mathrm{L}$ & NAS/NAE, 1973 \\
Cadmium, TR & $($ semitolerant crops) & \\
Chromium, TR & $2 \mathrm{mg} / \mathrm{L}$ & \\
Copper, TR & $($ tolerant crop) & \\
Iron, TR & $0.010 \mathrm{mg} / \mathrm{L}$ & NAS/NAE, 1973 \\
Lead, TR & $0.10 \mathrm{mg} / \mathrm{L}$ & NAS/NAE, 1973 \\
Manganese, TR & $0.20 \mathrm{mg} / \mathrm{L}$ & NAS/NAE, 1973 \\
Selenium, TR & $5.0 \mathrm{mg} / \mathrm{L}$ & NAS/NAE, 1973 \\
Zinc, TR & $5.0 \mathrm{mg} / \mathrm{L}$ & NAS/NAE, 1973 \\
\hline
\end{tabular}

ter samples from all the ponds contained the phytoplankton species Anacystis, in concentrations ranging from 780 to 170,000 cells per $\mathrm{mL}$ (table 18 ). A water sample from a control pond had the largest concentration of Anacystis and a water sample from a McAlester pond had the smallest concentration. Water samples from two McAlester ponds and one Croweburg pond had concentrations over 10,000 cells per $\mathrm{mL}$, the largest of which was 21,000 cells per $\mathrm{mL}$. Water samples from three ponds contained Anabaena concentrations ranging from 1,200 to 17,500 cells per $\mathrm{mL}$.

\section{Irrigation}

When an element in solution enters the soil, it may combine with the soil to decrease its concentration in solution and increase the content of that elementthe soil. Prolonged application of water containing large concentrations of the element will diminish and eventually exhaust the capacity of the soil to react with the element. Many soils have large capacities to react with trace elements. Therefore, irrigation water with large trace-element concentrations may be applied to some soils for many years before a steady state is approached. The application time depends on 
soil and plant factors and on the concentration of trace elements in the water. The suggested maximum concentration for continuous use on all soils are set for sandy soils that have low capacities to react with the element in question (National Academy of Sciences and National Academy of Engineering, 1973). These concentrations are used as criteria in this report, although some soils may have larger capacities.

Major cash crops in eastern Oklahoma are barley, corn, cotton, soybeans, peanuts, hay, sorghum, and oats (Oklahoma Water Resources Board, 1970 and 1971). These crops are semitolerant of boron and total dissolved-solids concentrations and tolerant of SAR, with the exception of barley and cotton, which are tolerant of total dissolved solids. Strawberries, fruit trees, and other sensitive crops are grown in eastern Oklahoma, although they are not major cash crops.

The water-quality criteria for irrigation are given in table 24. The comparison of the water-quality data from the ponds to the water-quality criteria are given in table 25 . Water from the epilimnion of 14 of the ponds is suitable for irrigation under almost all conditions. Water from the epilimnion of 20 ponds is suitable for irrigation of semitolerant crops, and water from the epilimnion of 25 ponds is suitable for irrigation of tolerant crops.

Measured pH's from all of the ponds except one control pond were within the recommended range of $\mathrm{pH}$. Measured $\mathrm{pH}$ in this pond exceeded the upper limit of 9.0 during summer sampling, which may be because of an algal bloom. Photosynthesis affects the amount of oxygen and carbon dioxide dissolved in the water which in turn affects the $\mathrm{pH}$ (Hem, 1985).

Only the McAlester group had ponds containing water with SAR's greater than the criterion. Water samples from the epilimnion in 3 of 9 ponds exceeded the SAR criterion of 4 for irrigation water for sensitive plants. The SAR's ranged from 5.5 to 32 . Water samples from the hypolimnion of 2 of 7 ponds exceeded this criterion, with SAR values of 7.6 and 19 (table 12). A water sample from one pond exceeded the criterion of 18 for high-tolerance crops in both zones.

The criterion most often exceeded for all crop categories was total dissolved-solids concentration. Of the 17 ponds containing water in the epilimnion that exceeded one or more criteria protective of sensitive crops, 15 ponds contained water with total dissolvedsolids concentrations exceeding the criterion of 500 $\mathrm{mg} / \mathrm{L}$. One control pond, 4 Croweburg ponds, 7 Iron Post ponds, and 3 McAlester ponds exceeded this criterion. The dissolved-solids concentrations in water samples from the epilimnion of 10 ponds exceeded the criterion protective of semitolerant plants of 1,000 $\mathrm{mg} / \mathrm{L}$. Dissolved-solids concentrations in water samples from 2 Croweburg ponds, 5 Iron Post ponds, and 3 McAlester ponds exceeded this criterion. The dissolved-solids concentrations in water samples from the epilimnion of four ponds exceeded the criterion for dissolved solids protective of tolerant plants of 2,000 $\mathrm{mg} / \mathrm{L}$. Dissolved-solids concentrations in water samples from 3 Iron Post ponds and 1 McAlester pond had dissolved-solids concentrations ranging from 2,210 to 2,770 $\mathrm{mg} / \mathrm{L}$ (table 12).

For the water in the hypolimnion, specific conductance values are used for comparison instead of dissolved solids because of the greater number of values. Water samples from 20 ponds had specific conductances greater than the criterion of $670 \mu \mathrm{S} / \mathrm{cm}$ for sensitive crops, which corresponds to $500 \mathrm{mg} / \mathrm{L}$ of dissolved solids. Water samples from 6 of 8 Croweburg ponds, 7 of 8 Iron Post ponds, 6 of 9 McAlester ponds, and 1 of 6 control ponds had specific conductances greater than the acceptable limit for sensitive crops. Water samples from 13 ponds exceeded the criterion of $1,330 \mu \mathrm{S} / \mathrm{cm}$ for semitolerant crops. Six of these ponds were Iron Post ponds. Water samples from six ponds exceeded the criterion of $2,670 \mu \mathrm{S} / \mathrm{cm}$ for tolerant crops. Water samples from two ponds from each of the strip-mine categories exceeded this criterion. The specific conductances of water samples from these six ponds ranged from 3,270 to $5,330 \mu \mathrm{S} / \mathrm{cm}$ (table 10 ).

Water samples from the epilimnion of all the ponds met the criteria for aluminum, cadmium, chromium, copper, iron, lead, manganese, and zinc. The trace element concentrations exceeding the criteria in one or more water sample from the epilimnion were boron and selenium. A water sample from one McAlester pond had a total recoverable boron concentration exceeding the criterion for sensitive plants of 0.75 $\mathrm{mg} / \mathrm{L}$ in both zones. Water samples from all ponds were within the boron criterion for semitolerant plants of $1 \mathrm{mg} / \mathrm{L}$. Water samples from three Iron Post ponds exceeded the selenium criterion of $20 \mu \mathrm{g} / \mathrm{L}$, with concentrations ranging from $26 \mu \mathrm{g} / \mathrm{L}$ to $78 \mu \mathrm{g} / \mathrm{L}$ (table 14 ).

Water samples from the hypolimnion exceeded more of the trace element criteria than water samples from the epilimnion. Water from one control pond had a maximum total recoverable aluminum concentration in excess of the criterion of $5 \mathrm{mg} / \mathrm{L}$, with a concentration of $6.6 \mathrm{mg} / \mathrm{L}$ (table 14). A water sample from another control pond had a maximum chromium concentration in excess of the criterion of $0.1 \mathrm{mg} / \mathrm{L}$ of total recoverable chromium with a concentration of $0.13 \mathrm{mg} / \mathrm{L}$ in the hypolimnion (table 14). These two ponds were resampled twice the following year and total recoverable aluminum and chromium concentra 
Table 25. Comparison of pond-water quality to water-quality criteria for irrigation

[min, minimum; max, maximum; TDS, total dissolved solids; SAR, sodium-absorption ratio; TR, total recoverable. The fraction used is the number of ponds exceeding the criterion over the total number of ponds with data; shallow samples were collected from the epilimnion; deep samples were collected from the hypolimnion]

\begin{tabular}{|c|c|c|c|c|c|c|c|c|}
\hline \multirow{3}{*}{ Variable } & \multicolumn{8}{|c|}{ Pond type and location of sample } \\
\hline & \multicolumn{2}{|c|}{ Control } & \multicolumn{2}{|c|}{ Croweburg } & \multicolumn{2}{|c|}{ Iron Post } & \multicolumn{2}{|c|}{ McAlester } \\
\hline & Shallow & Deep & Shaliow & Deep & Shallow & Deop & Shailow & Deep \\
\hline $\mathrm{pH}(\min )$ & $0 / 6$ & $0 / 6$ & $0 / 8$ & $0 / 8$ & $0 / 8$ & $0 / 8$ & $0 / 9$ & $0 / 9$ \\
\hline $\mathrm{pH}(\max )$ & $1 / 6$ & $0 / 6$ & $0 / 8$ & $0 / 8$ & $0 / 8$ & $0 / 8$ & $0 / 9$ & $0 / 9$ \\
\hline SAR (sensitive) & $0 / 6$ & $0 / 2$ & $0 / 8$ & $0 / 7$ & $0 / 8$ & $0 / 5$ & $3 / 9$ & $2 / 7$ \\
\hline SAR (tolerant) & $0 / 6$ & $0 / 2$ & $0 / 8$ & $0 / 7$ & $0 / 8$ & $0 / 5$ & $1 / 9$ & $1 / 7$ \\
\hline TDS (sensitive) & $1 / 6$ & $0 / 2$ & $4 / 8$ & $6 / 7$ & $7 / 8$ & $5 / 5$ & $3 / 9$ & $4 / 7$ \\
\hline Specific conductance & $1 / 6$ & $1 / 6$ & $4 / 8$ & $6 / 8$ & $7 / 8$ & $7 / 8$ & $4 / 9$ & $6 / 9$ \\
\hline TDS (semi-tolerant) & $0 / 6$ & $0 / 2$ & 2/8 & $3 / 7$ & $5 / 8$ & $4 / 5$ & $3 / 9$ & $4 / 7$ \\
\hline Specific conductance & $0 / 6$ & $0 / 6$ & $2 / 8$ & $3 / 8$ & $5 / 8$ & $6 / 8$ & $3 / 9$ & $4 / 9$ \\
\hline TDS (tolerant) & $0 / 6$ & $0 / 2$ & $0 / 8$ & $2 \pi$ & $3 / 8$ & $2 / 5$ & $1 / 9$ & $2 / 7$ \\
\hline Specific conductance & $0 / 6$ & $0 / 6$ & $0 / 8$ & $2 / 8$ & $2 / 8$ & $2 / 8$ & $1 / 9$ & $2 / 9$ \\
\hline Aluminum, TR & $0 / 6$ & $1 / 2$ & $0 / 8$ & $0 / 6$ & $0 / 8$ & $0 / 5$ & $0 / 8$ & $0 / 6$ \\
\hline Arsenic, TR & $0 / 6$ & $0 / 2$ & $0 / 8$ & $0 / 6$ & $0 / 8$ & $0 / 5$ & $0 / 8$ & $0 / 6$ \\
\hline $\begin{array}{l}\text { Boron, TR } \\
\text { (sensitive) }\end{array}$ & $0 / 6$ & $0 / 2$ & $0 / 8$ & $0 / 6$ & $0 / 8$ & $0 / 5$ & $1 / 8$ & $1 / 6$ \\
\hline $\begin{array}{l}\text { Boron } \\
\text { (semi-tolerant) }\end{array}$ & $0 / 6$ & $0 / 2$ & $0 / 8$ & $0 / 6$ & $0 / 8$ & $0 / 5$ & $0 / 8$ & $0 / 6$ \\
\hline Boron (tolerant) & $0 / 6$ & $0 / 2$ & $0 / 8$ & $0 / 6$ & $0 / 8$ & $0 / 5$ & $0 / 8$ & $0 / 6$ \\
\hline Cadmium, TR & $0 / 6$ & $0 / 2$ & $0 / 8$ & $0 / 6$ & $0 / 8$ & $0 / 5$ & $0 / 8$ & $0 / 6$ \\
\hline Chromium, TR & $0 / 6$ & $1 / 2$ & $0 / 8$ & $0 / 6$ & $0 / 8$ & $0 / 5$ & $0 / 8$ & $0 / 6$ \\
\hline Copper, TR & $0 / 6$ & $0 / 2$ & $0 / 8$ & $0 / 6$ & $0 / 8$ & $0 / 5$ & $0 / 8$ & $0 / 6$ \\
\hline Iron, TR & $0 / 6$ & $2 / 2$ & $0 / 8$ & $0 / 6$ & $0 / 8$ & $0 / 5$ & $0 / 8$ & $1 / 6$ \\
\hline Lead, TR & $0 / 6$ & $0 / 2$ & $0 / 8$ & $0 / 6$ & $0 / 8$ & $0 / 5$ & $0 / 8$ & $0 / 6$ \\
\hline Manganese, TR & $0 / 6$ & $2 / 2$ & $0 / 8$ & $2 / 6$ & $0 / 8$ & $0 / 5$ & $0 / 8$ & $1 / 6$ \\
\hline Selenium, TR & $0 / 6$ & $0 / 2$ & $0 / 8$ & $0 / 6$ & $3 / 8$ & $0 / 5$ & $0 / 8$ & $0 / 6$ \\
\hline Zinc, TR & $0 / 6$ & $0 / 2$ & $0 / 8$ & $0 / 6$ & $0 / 8$ & $0 / 5$ & $0 / 8$ & $0 / 6$ \\
\hline
\end{tabular}

tions were within the allowable limits in both water samples. Water samples collected from the hypolimnion of the 2 control ponds sampled and 1 of 6 McAlester ponds contained total recoverable iron and manganese concentrations in excess of the criteria of 5 and $10 \mathrm{mg} / \mathrm{L}$. Water samples from the hypolimnion of two of six Croweburg ponds contained manganese in excess of the criterion. The iron concentration in water samples from these ponds ranged from 6.2 to $34 \mathrm{mg} / \mathrm{L}$ (table 14). The manganese concentration ranged from
11 to $23 \mathrm{mg} / \mathrm{L}$ (table 14). Water samples from the epilimnion in all of the ponds met iron and manganese criteria.

\section{Recreation}

Recreation consists mainly of swimming and fishing as the ponds generally are too small for boating or sailing. The water-quality criteria for recreation are given in table 26 . The comparison of the water-quality 
data from the ponds to the water-quality criteria are given in table 27

Table 26. Water-quality criteria for recreation [in., inches; $\mathrm{mg} / \mathrm{L}$, milligram per liter, EPA, U.S. Environmental Protection Agency; NTAC, National Technical Advisory Committee to the Secretary of the Interior, NAS/NAE, National Academy of Sciences and National Academy of Engineering]

\begin{tabular}{lcl}
\hline \multicolumn{1}{c}{ Constituent } & $\begin{array}{c}\text { Water-quality } \\
\text { criterla }\end{array}$ & \multicolumn{1}{c}{ Source } \\
\hline $\mathrm{pH}$ & $6.5-8.3$ & NAS/NAE, 1973 \\
Secchi disk depth & $48 \mathrm{in}$. & NTAC, 1968 \\
Phosphate, total as $\mathrm{P}$ & $.025 \mathrm{mg} / \mathrm{L}$ & EPA, 1987 \\
\hline
\end{tabular}

seasonally for some of the ponds. When the mean Secchi-disk depth per pond per visit was used, water from 20 ponds exceeded the criterion. The mean or average Secchi depth for all study ponds is 48 in. The mean Secchi depths for the control, Croweburg, Iron Post, and McAlester ponds were 57, 49, 575, and 36 in., respectively.

The EPA recommends a criterion for total phosphate reported as phosphorus of $0.025 \mathrm{mg} / \mathrm{L}$. Using total phosphorus reported as phosphorus and, assuming that the total phosphorus is an estimate of total phosphate, water samples from the epilimnion of 9 of 29 ponds contained total phosphate in excess of the criterion protective of recreation. A water sample from one control pond had a total phosphorus concentration of $0.42 \mathrm{mg} / \mathrm{L}$ in the epilimnion. Total phosphate in water samples from the epilimnion of the other ponds that exceeded the criterion ranged from 0.03 to $0.10 \mathrm{mg} / \mathrm{L}$ (table 13). Total phosphate concentration in water

Table 27. Comparison of pond-water quality to water-quality criteria for recreation

[NA, not applicable; min, minimum; max, maximum; TR, total recoverable. The fraction used is the number of ponds exceeding the criterion over the total number of ponds with data; shallow samples were collected from the epilimnion; deep samples were collected from the hypolimnion]

\begin{tabular}{|c|c|c|c|c|c|c|c|c|}
\hline \multirow{3}{*}{ Variable } & \multicolumn{8}{|c|}{ Pond type and location of sample } \\
\hline & \multicolumn{2}{|c|}{ Control } & \multicolumn{2}{|c|}{ Croweburg } & \multicolumn{2}{|c|}{ Iron Poat } & \multicolumn{2}{|c|}{ McAlester } \\
\hline & Shallow & Deep & Shallow & Deep & Shallow & Deep & Shallow & Deep \\
\hline $\mathrm{pH}(\min )$ & $1 / 6$ & $3 / 6$ & $0 / 8$ & $1 / 8$ & $0 / 8$ & $1 / 8$ & $0 / 9$ & $1 / 9$ \\
\hline $\mathrm{pH}(\max )$ & $3 / 6$ & $0 / 6$ & $4 / 8$ & $0 / 8$ & $3 / 8$ & $0 / 8$ & $4 / 9$ & $0 / 9$ \\
\hline Secchi depth & $4 / 6$ & NA & $7 / 8$ & NA & $4 / 8$ & NA & $7 / 9$ & NA \\
\hline Phosphate, TR & $1 / 5$ & $3 / 4$ & $2 / 8$ & $5 / 8$ & $4 / 8$ & $3 / 4$ & $2 / 8$ & $4 / 6$ \\
\hline
\end{tabular}

Water samples from 29 ponds exceeded one or more criteria protective of swimming. Measured $\mathrm{pH}$ in 15 ponds was outside the water-quality criterion range protective of swimming. Measured $\mathrm{pH}$ in ponds from all groups contained water with $\mathrm{pH}$ values outside the recommended range of 6.5 to 8.3. The maximum $\mathrm{pH}$ in water from most of these ponds exceeded the upper limit of 8.3, with $\mathrm{pH}$ values ranging from 8.4 to 10.0 (table 10). Croweburg ponds most often exceeded the criterion, with 4 of 8 ponds containing water exceeding this criterion.

Sites from 22 ponds had minimum Secchi-disk depths less than the recommended depth of 48 in. The Secchi-disk depth often changed from one site to another within a pond and varied by 50 percent or more samples from the hypolimnion of 15 of 22 ponds exceeded the criterion. Total phosphate concentrations in water samples from the ponds exceeding the criterion in the hypolimnion ranged in concentration from 0.03 to $1.6 \mathrm{mg} / \mathrm{L}$. Some ponds in all groups contained water that exceeded the phosphate criterion.

Some ponds formed by strip mining may not be suited for swimming for safety reasons. According to the Oklahoma Conservation Commission (1987), some ponds formed by strip mining are safety hazards because of the depth of water and steep vertical banks. Unreclaimed ponds formed by coal mining tend to have steeper banks than reclaimed ponds or control ponds. 


\section{SUMMARY}

Water in many of the ponds can be used for public water supplies if other sources are not available. Water in many of these ponds exceeds one or more SMCL's, but meets all MCL's. In general, most of the ponds are well suited for use by wintering and migrating waterfowl, livestock watering, and for irrigation of semitolerant and tolerant crops. Many ponds are marginally suited for aquatic life and irrigation of sensitive crops, but may be unsuitable for swimming.

Water samples from six of the ponds exceeded one of the MCL's in the epilimnion (table 28). Total lead and mercury criteria were exceeded by one sample each. Water samples from five Iron Post ponds exceeded the selenium criteria. Water samples from the epilimnion of 29 ponds exceeded one or more SMCL's. This water is less desirable for domestic use, but often can be used if a better supply is not available. The water-quality criteria most often exceeded were dissolved solids, sulfate, and total iron and manganese. Water samples from 15 ponds exceeded dissolvedsolids and sulfate criteria in the epilimnion. Iron Post ponds had the highest percentage of water samples exceeding dissolved solids and sulfate criteria, while control ponds had the smallest percentage of water samples exceeding the criteria. The epilimnion has better water quality and meets more of the criteria than the hypolimnion. All samples from the hypolimnion exceeded one or more SMCL's.

Many ponds are marginally suited for aquatic life. Water samples from 18 ponds exceeded one or more criteria in the epilimnion. Water samples from five ponds exceeded only one criteria. Dissolved oxygen concentrations were less than the recommended

Table 28. Comparison of the number of ponds with samples exceeding one or more water-quality criteria for each water use

[MCL, maximum contamination level; SMCL, secondary maximum contamination level; biological criteria were not used; shallow samples were collected from the epilimnion; deep samples were collected from the hypolimnion]

\begin{tabular}{|c|c|c|c|c|c|c|c|c|}
\hline \multirow{3}{*}{ Water use } & \multicolumn{8}{|c|}{ Pond type and locatlon of sample } \\
\hline & \multicolumn{2}{|c|}{ Control } & \multicolumn{2}{|c|}{ Croweburg } & \multicolumn{2}{|c|}{ Iron Post } & \multicolumn{2}{|c|}{ McAlester } \\
\hline & Shallow & Deep & Shallow & Deep ${ }^{1}$ & Shallow & Deep' & Shallow & Deep' \\
\hline \multicolumn{9}{|l|}{ Domestic: } \\
\hline One or more MCL & $0 / 6$ & $1 / 2$ & $0 / 8$ & $4 / 7$ & $6 / 8$ & $3 / 5$ & $1 / 9$ & $2 \pi$ \\
\hline One or more $\mathrm{SMCL}^{2}$ & $5 / 6$ & $3 / 3$ & $8 / 8$ & $7 \Pi$ & $8 / 8$ & $7 \Pi$ & $8 / 9$ & $7 \pi$ \\
\hline Aquatic life ${ }^{23}$ & $5 / 6$ & $4 / 4$ & $3 / 8$ & $8 / 8$ & $4 / 8$ & $5 / 6$ & $6 / 9$ & $6 / 8$ \\
\hline Waterfowl ${ }^{4}$ & $5 / 6$ & $5 / 6$ & $1 / 8$ & $6 / 8$ & $5 / 8$ & $5 / 8$ & $1 / 9$ & $7 / 9$ \\
\hline \multicolumn{9}{|l|}{ Livestock: $:^{5}$} \\
\hline Sensitive & $0 / 6$ & $1 / 2$ & $0 / 8$ & $2 / 6$ & $2 / 8$ & $1 / 5$ & $1 / 9$ & $1 / 6$ \\
\hline Tolerant & $0 / 6$ & $1 / 2$ & $0 / 8$ & $0 / 7$ & $2 / 8$ & $0 / 5$ & $1 / 9$ & $0 / 6$ \\
\hline \multicolumn{9}{|l|}{ Irrigation: } \\
\hline Sensitive & $2 / 6$ & $3 / 3$ & $4 / 8$ & $6 / 6$ & $7 / 8$ & $7 \pi$ & $4 / 8$ & $6 / 8$ \\
\hline Semi-tolerant & $1 / 6$ & $2 / 2$ & $2 / 8$ & $4 / 6$ & $5 / 8$ & $6 \pi$ & $3 / 8$ & $5 \pi$ \\
\hline Tolerant & $1 / 6$ & $2 / 2$ & $0 / 8$ & $3 / 6$ & $4 / 8$ & $3 / 6$ & $1 / 8$ & $3 / 6$ \\
\hline Recreation & $5 / 6$ & $3 / 4$ & $6 / 8$ & $6 / 8$ & $7 / 8$ & $3 / 4$ & $9 / 9$ & $5 / 7$ \\
\hline $\begin{array}{l}{ }^{1} \text { Sites that exce } \\
\text { exceed any criteria but } \\
{ }^{2} \text { The summatio } \\
{ }^{3} \text { Concentration } \\
{ }^{4} \text { The summatio } \\
\text { The number of ponds ex } \\
\text { wintering and migration }\end{array}$ & $\begin{array}{l}\text { ed a criter } \\
\text { not have } \\
\text { does not in } \\
\text { hat were le } \\
\text { does not us } \\
\text { eding a cr }\end{array}$ & $\begin{array}{l}\text { and con } \\
\text { gh data } \\
\text { e the di } \\
\text { an the } \\
\text { e tempe } \\
\text { on in th }\end{array}$ & $\begin{array}{l}\text { ed incompl } \\
\text { ompare to } \\
\text { ved oxygen } \\
\text { ction limit } \\
\text { e criterion } \\
\text { llow strata }\end{array}$ & $\begin{array}{l}\text { data we } \\
\text { of the cr } \\
\text { iterion b } \\
\text { re not us } \\
\text { ecause al } \\
\text { st appro }\end{array}$ & $\begin{array}{l}\text { ounted in } \\
\text { a were not } \\
\text { use all of } t \\
n \text { the sumr } \\
\text { the ponds } \\
\text { ate the nur }\end{array}$ & $\begin{array}{l}\text { otal. Sit } \\
\text { anted in } \\
\text { onds ex } \\
\text { on. } \\
\text { eed this } \\
\text { r of pon }\end{array}$ & $\begin{array}{l}\text { vith data th } \\
\text { total. } \\
\text { d this criter } \\
\text { erion durin } \\
\text { xceeding a }\end{array}$ & $\begin{array}{l}\text { summe } \\
\text { ria in th }\end{array}$ \\
\hline
\end{tabular}


minimum in the hypolimnion of all ponds during the summer. Fish could survive by staying in the epilimnion. However, low dissolved-oxygen levels in the hypolimnion decrease the available habitat for fish and affects the type and number of benthic invertebrates found. Water samples from 26 ponds exceeded one ormore trace element criteria in either the epilimnion, the hypolimnion, or both. The mercury criterion was exceeded the most often.

Water from many of the ponds met the criteria protective of waterfowl during the early spring. Water samples from 18 ponds met the criteria for $\mathrm{pH}$, alkalinity, and selenium in the spring. Control ponds had the highest percentage of ponds with water exceeding the $\mathrm{pH}$ and alkalinity criteria. However, control ponds tend to be shallower and have more macrophytes, which favor waterfowl utilization. Water samples from 5 of 8 Iron Post ponds exceeded the criteria for selenium. The study ponds generally are not suited for yearround raising of waterfowl because of high temperatures and low dissolved oxygen during the summer months.

Most of the ponds contained water suited for livestock watering. Water samples from the epilimnion of 28 ponds met all of the chemical and physical criteria. Water samples from five ponds exceeded one or more criteria in the hypolimnion. All of the ponds contained the phytoplankton genus Anacystis, which is toxic to livestock. The concentrations of Anacystis ranged from 780 cells per milliliter to 170,000 cells per milliliter. Three ponds also contained Anabaena in concentrations ranging from 1,200 to 17,500 cells per milliliter. The toxicity level of these phytoplankton species is unknown.

Water from most of the ponds is marginally suitable for irrigation of sensitive crops, but more suitable for irrigation of semitolerant and tolerant crops. Water samples from the epilimnion of 14 ponds were suitable for irrigation under almost all soil conditions and crops. Water samples from the epilimnion of 20 ponds were suitable for irrigation of semitolerant crops and water samples from the epilimnion of 25 ponds were suitable for irrigation of tolerant crops. The criterion most often exceeded for all crop categories was total dissolved solids. Of the 17 ponds with water exceeding criteria for sensitive crops, water samples from 15 ponds exceeded this criterion. A larger percentage of water samples from Iron Post ponds exceeded the criterion than did the other groups. Water samples from control ponds exceeded the criterion the least. Water samples from 10 ponds exceeded the dissolved-solids criterion protective of semitolerant crops in the epilimnion and water samples from 4 ponds exceeded the dissolved-solids criterion protective of tolerant crops. Water samples from the epilimnion of three McAlester ponds exceeded the SAR criterion. Water samples from the epilimnion of three Iron Post ponds exceeded the selenium criterion. Water samples from all of the ponds met the criteria for iron and manganese in the epilimnion. Water samples from the hypolimnion of 3 of 19 ponds sampled exceeded the criterion for iron. Water samples from the hypolimnion from five ponds exceeded the criterion for manganese.

Recreation consists mainly of swimming and fishing, as the ponds are generally too small for boating or sailing. Most of the ponds are not suited for swimming. Water samples from the epilimnion of 15 ponds had $\mathrm{pH}$ values outside the range protective of swimming. Water samples from most of these ponds exceeded the maximum recommended $\mathrm{pH}$. Water samples from 22 ponds had minimum Secchi-disk depth measurements less than the recommended depth for diving during either the summer or spring. The total phosphate criterion was exceeded in water samples from the epilimnion of 9 of 29 ponds and in water samples from the hypolimnion of 15 of 22 ponds. Swimming in some of the ponds formed by strip mining may be dangerous because of steep banks.

\section{SELECTED REFERENCES}

American Public Health Association, American Water Works Association, and Water Pollution Control Federation, 1985, Standard methods for the examination of water and wastewater (16th ed.): Washington D.C., 1,268 p.

Averitt, Paul, 1975, Coal resources of the United States, January 1, 1974: U.S. Geological Survey Bulletin $1412,131 \mathrm{p}$.

Bellrose, F.C., 1968, Waterfowl migration corridors east of the Rocky Mountains in the United States: Illinois Natural History Survey Biological Notes, no. 61, $24 \mathrm{p}$.

1976, Ducks, geese, and swans of North American (2d ed.): Harrisburg, Pa., Stackpole Books, 544 p.

Brown, Eugene, Skougstad, M.W., and Fishman M.J., 1970, Methods for collection and analysis of water samples for dissolved minerals and gases: U.S. Geological Survey Techniques of Water-Resources Investigations, Book 5, Chapter A1, $160 \mathrm{p}$.

Brown, Randall, 1987, Selenium threatens irrigators, wildlife: Civil Engineering, v. 57, no. 2, p. 40.

Chabbreck, R.H., 1979, Winter habitat of dabbling ducks physical, chemical, and biological aspects., in T.A. Bookout, ed., Waterfowl and wetlands, an integrated review: Proceedings of 1977 
Symposium, Madison, Wis., The Wildlife Society, p. 133-141.

Cole, G.E., 1975, Textbook of limnology: St. Louis, Mo., C.V. Mosby Co., 283 p.

Digesti, R.S., and Weeth, A.J., 1973, Effects of sulfate water on cattle: Proceedings of West Section, American Society of Animal Science, v. 24, p. 259-263.

Ferreira, R.F., and Lambing J.H., 1984, Suitability of water quality for fish propagation, waterfowl habitat, livestock watering, and recreational use at 12 reservoirs in eastern Montana: U.S. Geological Survey Water-Resources Investigations Report $84-4085,96$ p.

Fritz, E.S., 1980, Potential impacts of low $\mathrm{pH}$ on fish and shellfish populations: National Power Plant Team, Office of Biological Service, FWS/OBS-80/40.2, $14 \mathrm{p}$.

Friedman, S.A., 1974, Investigation of the coal reserves in the Ozarks Section of Oklahoma and their potential uses: Final Report To the Ozarks Regional Commission July 1974, 115 p.

1978, Field description and characterization of coals sampled by the Oklahoma Geological Survey, 1971-1976: in Dutcher, R.R., ed., Field Description of Coal: American Society for Testing and Materials, Special Technical Publication 661, p. 5863.

1982, Map of eastern Oklahoma showing locations of active coal mines, 1977-79: Oklahoma Geological Survey Map GM-24, scale 1:500,000, 1 sheet

Goldman, C.R., and Horne, A.J., 1983, Limnology: New York, McGraw-Hill, 464 p.

Hem, J.D., 1985, Study and interpretation of the chemical characteristics of natural water (3d ed.): U.S. Geological Survey Water-Supply Paper 2254, $263 \mathrm{p}$.

Hemish, L.A., 1987, Names of coal beds in the northeastern Oklahoma shelf area: Oklahoma Geological Survey Geology Notes, v. 47, no.3, p. 96-113.

Johnson, K.S., 1974, Maps and description of disturbed and reclaimed surface-mined coal lands in eastern Oklahoma, showing acreage disturbed and reclaimed through June 1973: Oklahoma Geological Survey Map GM-17, 3 sheets, scale $1: 125,000,21 \mathrm{p}$.

Johnson, K.S., Kidd, C.M., and Butler, R.C., 1981, Bibliography of abandoned coal-mine lands in Oklahoma: Oklahoma Geological Survey Special Publication 81-2, $84 \mathrm{p}$.

Karvelot, M.D., 1973, The Stigler coal and collateral strata in parts of Haskell, Le Flore, McIntosh, and
Muskogee Counties, Oklahoma: Oklahoma City Geological Society Shale Shaker, v. 23, no. 5, p.108-199 and v. 23, no. 6, p.128-141.

McKee, J.E.and Wolf, H.W., 1963, Water Quality Criteria, Second Edition: California Water Resources Control Board Publication 3-A, 548 p.

Marcher, M.V., Bergman, D.L., Slack, L.J., and Blumer, S.P., 1987, Hydrology of Area 41, Western Region, Interior Coal Province, Oklahoma, and Arkansas: U.S. Geological Survey Water-Resources Investigations Open-File Report 84-129, 86 p.

Marcher, M.V., Kenny J.F., and others, 1984, Hydrology of Area 40, Western Region, Interior Coal Province, Kansas, Oklahoma, and Missouri: U.S. Geological Survey Water-Resources Investigations Open-File Report 83-266, 97 p.

National Academy of Sciences and National Academy of Engineering, 1973, Water-quality criteria 1972: U.S. Environmental Protection Agency, Environmental Research Series, Washington, D.C., U.S. Government Printing Office, $594 \mathrm{p}$.

National Technical Advisory Committee to the Secretary of the Interior, 1968, Water-quality criteria: Washington, D.C., U.S. Government Printing Office, $234 \mathrm{p}$.

Oklahoma Conservation Commission, 1987, Reclaiming Oklahoma's abandoned mine land; A ten-year progress report: Norman, Okla., Oklahoma University Printing Services, $24 \mathrm{p}$.

Oklahoma Department of Mines, 1987, Annual report of the Oklahoma Mining Commission for 1985 and 1986: Oklahoma City, Okla., Oklahoma Department of Mines, 61 p.

Oklahoma Water Resources Board, 1970, Appraisal of the water and related land resources of Oklahoma; Region Seven: Oklahoma Water Resources Board Publication 29, 141 p.

1971, Appraisal of the water and related land resources of Oklahoma; Region Nine: Oklahoma Water Resources Board Publication 36, 149 p. 1985, Oklahoma's water-quality standards, 1985 : Research and Standards Section, Water-Quality Division, Oklahoma Water Resources Board, 110 p. 1993, Water quality standards, as of June 25,1993 : OAC 785:45, no pagination.

Rawson, D.S., and Moore, J.E., 1944, The saline ponds of Saskatchewan: Canadian Journal of Research, v. 22, $141 \mathrm{p}$.

Reid, G.K., and Wood, R.D., 1976, Ecology of inland waters and Estuaries ( $2 \mathrm{~d}$ ed.): New York, Van Nostrand, $485 \mathrm{p}$. 
Sawyer, C.N., 1960, Chemistry of sanitary engineers: New York, McGraw-Hill.

Schnell, G.D., Johnson F.L., and Gentry J.L., 1979, Flora and fauna of Oklahoma abandoned mine lands: Oklahoma Biological Survey, $132 \mathrm{p}$.

Skougstad, M.W., Fishman, M.J., Friedman, L.C., Erdmann, D.E., and Duncan, S.S., eds., 1979, Methods for determination of inorganic substances in water and fluvial sediments: U.S. Geological Survey Techniques of Water-Resources Investigations, Book 5, Chapter A1, 625 p.

Slack, L.J., and Blumer, S.P., 1987, Physical and chemical characteristics of water in coal-mine ponds, Eastern Oklahoma, June to November 1977-81: Oklahoma Geological Survey Special Publication 87-2, 116 p.

Smith, G.R., 1976, Botulism in waterfowl: Wildfowl, v. 49, p. $129-138$

U.S. Environmental Protection Agency, 1986a, Quality criteria for water, 1986: Washington, D.C., Office of Water Regulations and Standards, EPA 440/5-86001 , 1986b, Maximum contaminant levels (subpart B of part 141, National interim primary drinking-water regulations): U.S. Code of Federal Regulations, Title 40, Parts 100 to 149, revised as of July 1, 1986, p. 524-528

1986c, Secondary maximum contaminant levels (section 143.3 of part 143, National secondary drinking-water regulations): U.S. Code of Federal Regulations, Title 40, Parts 100 to 149, revised as of July 1,1986 , p. 587-590.

1987, Quality criteria for water, 1986, updated September 1987: Office of Water Regulations and Standards, Washington, D.C., EPA 440/5-86-001,

1993, Drinking water regulations and health advisories: Office of Water, U.S. Environmental Protection Agency, Safe Drinking Water Hotline, no pagination.

Welch, Paul S., 1952, Limnology: New York, McGraw-Hill Book, 538 p.

Wetzel, R.G., 1983, Limnology: Philadelphia, Saunders College Publishing, 743 p. 
Tạble 1.-Concentrations of chlorophyll A, B, and C in water samples from study ponds [All results are in micrograms per liter, $<$, less than]

\begin{tabular}{cccc}
\hline \multicolumn{4}{c}{ Control Pond 1 } \\
Collocted 07/23/85 \\
\hline Site & Chlorophyll A & Chlorophyll B & Chlorophyll C \\
\hline 5 & 16.0 & 2.00 & 7.00 \\
7 & 173 & 13.0 & 76.0 \\
7 & 180 & 29.0 & 112 \\
8 & 20.0 & 4.00 & 10.0 \\
10 & 5.00 & 2.00 & $<1.00$ \\
10 & 6.00 & 2.00 & 3.00 \\
Median & 18.0 & 3.00 & 8.00 \\
\hline \hline
\end{tabular}

Control Pond 2

Collocted 07/17/85

\begin{tabular}{rccc}
\hline Site & Chlorophyll A & Chlorophyll B & Chlorophyll C \\
\hline 1 & 179 & 66.0 & 123 \\
3 & 122 & 68.0 & 134 \\
4 & 46.0 & 33.0 & 46.0 \\
6 & 70.0 & 16.0 & 36.0 \\
7 & 143 & 20.0 & 14.0 \\
\hline Median & 122 & 33.0 & 46.0 \\
\hline \hline
\end{tabular}

Control Pond 3

Collocted 07/25/85

\begin{tabular}{rccc}
\hline Site & Chlorophyll A & Chlorophyll B & Chlorophyll C \\
\hline 3 & 7.00 & 9.00 & 12.0 \\
3 & 2.00 & $<1.00$ & $<1.00$ \\
5 & 1.00 & $<1.00$ & $<1.00$ \\
5 & 1.00 & 1.00 & $<1.00$ \\
6 & 1.00 & 1.00 & $<1.00$ \\
6 & 1.00 & $<1.00$ & $<1.00$ \\
10 & 1.00 & $<1.00$ & $<1.00$ \\
10 & 1.00 & 2.00 & $<1.00$ \\
11 & 2.00 & 2.00 & $<1.00$ \\
11 & 3.00 & 1.00 & $<1.00$ \\
Median & 1.00 & 1.00 & $<1.00$ \\
\hline \hline
\end{tabular}


Table 1. - Concentrations of chlorophyll A, B, and C in water samples from study ponds-Continued

\begin{tabular}{cccc}
\hline \multicolumn{4}{c}{ Control Pond 4 } \\
Colloctod 08/16/85 \\
\hline Site & Chlorophyll A & Chlorophyll B & Chlorophyll C \\
\hline 2 & 2.00 & $<1.00$ & $<1.00$ \\
3 & 2.00 & 1.00 & 1.00 \\
4 & 2.00 & $<1.00$ & 1.00 \\
5 & 1.00 & 1.00 & 1.00 \\
6 & 3.00 & $<1.00$ & 1.00 \\
\hline Median & 2.00 & $<1.00$ & 1.00 \\
\hline \hline
\end{tabular}

Control Pond 5

Collected 08/16/85

\begin{tabular}{rccc}
\hline Site & Chlorophyll A & Chlorophyll B & Chlorophyll C \\
\hline 2 & 3.00 & 2.00 & 3.00 \\
3 & 4.00 & 1.00 & 3.00 \\
5 & 5.00 & 2.00 & 3.00 \\
7 & 9.00 & 4.00 & 6.00 \\
Median & 4.00 & 2.00 & 3.00 \\
\hline \hline
\end{tabular}

Control Pond 6

Collected 08/15/85

\begin{tabular}{cccc}
\hline Site & Chlorophyll A & Chlorophyll B & Chlorophyll C \\
\hline 1 & 3.00 & 1.00 & 1.00 \\
2 & 4.00 & 1.00 & 3.00 \\
5 & 4.00 & 1.00 & 2.00 \\
6 & 4.00 & 1.00 & 3.00 \\
7 & 4.00 & 1.00 & 1.00 \\
8 & 3.00 & 1.00 & 2.00 \\
10 & 3.00 & 1.00 & 2.00 \\
Median & 4.00 & 1.00 & 2.00 \\
\hline \hline
\end{tabular}

Croweburg Coal Pond 1

Collected 08/13/85

\begin{tabular}{rccc}
\hline Site & Chiorophyll A & Chlorophyll B & Chlorophyll C \\
\hline 2 & 13.0 & 2.00 & 1.00 \\
4 & 52.0 & 6.00 & 3.00 \\
5 & 51.0 & 6.00 & 4.00 \\
7 & 39.0 & 8.00 & 6.00 \\
8 & 65.0 & 6.00 & 5.00 \\
10 & 71.0 & 11.0 & 1.00 \\
Median & 52.0 & 6.00 & 4.00 \\
\hline \hline
\end{tabular}


Table 1.-Concentrations of chlorophyll A, B, and C in water samples from study ponds-Continued

\begin{tabular}{|c|c|c|c|}
\hline \multicolumn{4}{|c|}{ Croweburg Coal Pond 2} \\
\hline Site & Chlorophyll A & Chlorophyll B & Chlorophyll C \\
\hline 1 & 2.00 & 1.00 & $<1.00$ \\
\hline 3 & 2.00 & $<1.00$ & $<1.00$ \\
\hline 5 & 2.00 & 1.00 & 1.00 \\
\hline Median & 2.00 & 1.00 & $<1.00$ \\
\hline \multicolumn{3}{|c|}{ Croweburg Coal Pond 3} & Collected 08/01/85 \\
\hline Slte & Chlorophyll A & Chlorophyll B & Chlorophyll C \\
\hline 1 & 4.00 & 1.00 & $<1.00$ \\
\hline 2 & 5.00 & 2.00 & 2.00 \\
\hline 3 & 5.00 & 1.00 & $<1.00$ \\
\hline 4 & 3.00 & 1.00 & 1.00 \\
\hline 7 & 1.00 & 1.00 & $<1.00$ \\
\hline Median & 4.00 & 1.00 & $<1.00$ \\
\hline \multirow{2}{*}{\multicolumn{4}{|c|}{$\begin{array}{l}\text { Croweburg Coal Pond } 4 \\
\text { Collected 08/07/85 }\end{array}$}} \\
\hline & & & \\
\hline Site & Chlorophyll A & Chlorophyll B & Chlorophyll C \\
\hline 1 & 3.00 & 2.00 & 1.00 \\
\hline 3 & 3.00 & 2.00 & 1.00 \\
\hline 4 & 3.00 & 2.00 & 2.00 \\
\hline 6 & 2.00 & 1.00 & 1.00 \\
\hline 7 & 4.00 & 2.00 & $<1.00$ \\
\hline 9 & 3.00 & 3.00 & $<1.00$ \\
\hline 9 & 4.00 & 2.00 & $<1.00$ \\
\hline Median & 3.00 & 2.00 & 1.00 \\
\hline \multicolumn{4}{|c|}{ Croweburg Coal Pond 5} \\
\hline \multicolumn{4}{|c|}{ Collected 08/14/85 } \\
\hline Site & Chlorophyll A & Chlorophyll B & Chlorophyll C \\
\hline 1 & 1.00 & $<1.00$ & 2.00 \\
\hline 2 & $<1.00$ & 1.00 & 1.00 \\
\hline 4 & 2.00 & 1.00 & 2.00 \\
\hline 6 & 2.00 & 1.00 & 1.00 \\
\hline Median & 2.00 & 1.00 & 2.00 \\
\hline
\end{tabular}


Table 1.-Concentrations of chlorophyll A, B, and C in water samples from study ponds-Continued

\begin{tabular}{|c|c|c|c|}
\hline \multicolumn{4}{|c|}{$\begin{array}{l}\text { Croweburg Coal Pond } 6 \\
\text { Collocted 08/13/85 }\end{array}$} \\
\hline Site & Chlorophyll A & Chiorophyll B & Chlorophyll C \\
\hline 4 & 1.00 & 1.00 & 1.00 \\
\hline 5 & 2.00 & 1.00 & 1.00 \\
\hline 6 & $<1.00$ & 1.00 & 2.00 \\
\hline 7 & $<1.00$ & $<1.00$ & $<1.00$ \\
\hline 8 & 1.00 & 1.00 & 2.00 \\
\hline Median & 1.00 & 1.00 & 1.00 \\
\hline \multicolumn{4}{|c|}{ Croweburg Coal Pond 7} \\
\hline \multicolumn{4}{|c|}{ Collected 08/21/85 } \\
\hline Site & Chlorophytl A & Chlorophyll B & Chlorophyll C \\
\hline 1 & 2.00 & 3.00 & $<1.00$ \\
\hline 1 & 2.00 & 4.00 & $<1.00$ \\
\hline 3 & 1.00 & 1.00 & 1.00 \\
\hline 5 & 2.00 & 1.00 & 1.00 \\
\hline 6 & 1.00 & 1.00 & 1.00 \\
\hline 7 & 1.00 & 1.00 & 2.00 \\
\hline 9 & 1.00 & 2.00 & $<1.00$ \\
\hline Median & 1.00 & 1.00 & 1.00 \\
\hline \multicolumn{4}{|c|}{ Croweburg Coal Pond 8} \\
\hline \multicolumn{4}{|c|}{ Coilected 08/15/85 } \\
\hline Site & Chlorophyil A & Chlorophyll B & Chlorophyll C \\
\hline 2 & 2.00 & $<1.00$ & 2.00 \\
\hline 6 & 2.00 & 1.00 & 1.00 \\
\hline 7 & 2.00 & 1.00 & 2.00 \\
\hline 8 & 2.00 & $<1.00$ & 1.00 \\
\hline 10 & 2.00 & 1.00 & $<1.00$ \\
\hline Median & 2.00 & 1.00 & 2.00 \\
\hline \multicolumn{4}{|c|}{$\begin{array}{l}\text { iron Post Coal Pond } 1 \\
\text { Collected 08/08/85 }\end{array}$} \\
\hline Site & Chlorophyll A & Chlorophyll B & Chlorophyll C \\
\hline 1 & 8.00 & 7.00 & $<1.00$ \\
\hline 1 & 2.00 & 5.00 & $<1.00$ \\
\hline 3 & 5.00 & 4.00 & $<1.00$ \\
\hline 4 & 4.00 & 3.00 & 2.00 \\
\hline 6 & 5.00 & 4.00 & $<1.00$ \\
\hline 6 & 5.00 & 3.00 & $<1.00$ \\
\hline 7 & 5.00 & 3.00 & $<1.00$ \\
\hline Median & 5.00 & 4.00 & $<1.00$ \\
\hline
\end{tabular}


Table 1.-Concentrations of chlorophyll A, B, and C in water samples from study ponds-Continued

\begin{tabular}{cccc}
\hline \multicolumn{4}{c}{$\begin{array}{c}\text { Iron Post Coal Pond 2 } \\
\text { Collected 08/12/85 }\end{array}$} \\
\hline Site & Chlorophyll A & Chlorophyll B & Chlorophyll C \\
\hline 1 & 1.00 & 2.00 & 1.00 \\
2 & 3.00 & 2.00 & 2.00 \\
3 & 1.00 & 1.00 & 3.00 \\
4 & 3.00 & 1.00 & $<1.00$ \\
5 & 2.00 & 1.00 & 1.00 \\
Median & 2.00 & 1.00 & 1.00 \\
\hline \hline
\end{tabular}

Iron Post Coal Pond 3

Collocted 08/12/85

\begin{tabular}{rccc}
\hline Site & Chlorophyll A & Chlorophyll B & Chlorophyll C \\
\hline 2 & 4.00 & 2.00 & $<1.00$ \\
3 & 7.00 & 2.00 & 4.00 \\
4 & 3.00 & 1.00 & 3.00 \\
5 & 4.00 & 2.00 & 4.00 \\
6 & 6.00 & 2.00 & 5.00 \\
\cline { 2 - 4 } Median & 4.00 & 2.00 & 4.00 \\
\hline \hline
\end{tabular}

Iron Post Coal Pond 4

Collected 08/06/85

\begin{tabular}{rccc}
\hline Site & Chlorophyll A & Chlorophyll B & Chlorophyll C \\
\hline 1 & 18.0 & 2.00 & 4.00 \\
3 & 32.0 & 2.00 & $<1.00$ \\
4 & 21.0 & 4.00 & 4.00 \\
6 & 22.0 & 3.00 & 8.00 \\
7 & 24.0 & 3.00 & 8.00 \\
Median & 22.0 & 3.00 & 4.00 \\
\hline
\end{tabular}

Iron Post Coal Pond 5

Collected 08/06/85

\begin{tabular}{cccc}
\hline Site & Chlorophyll A & Chlorophyll B & Chlorophyll C \\
\hline 2 & 2.00 & 1.00 & 2.00 \\
2 & 2.00 & 1.00 & 3.00 \\
3 & 4.00 & 4.00 & 3.00 \\
4 & 5.00 & 2.00 & 5.00 \\
4 & 3.00 & 1.00 & 2.00 \\
4 & 3.00 & 1.00 & 1.00 \\
Median & 2.00 & 1.00 & 2.00 \\
\hline \hline
\end{tabular}


Table 1.-Concentrations of chlorophyll A, B, and C in water samples from study ponds-Continued

\begin{tabular}{|c|c|c|c|}
\hline \multicolumn{4}{|c|}{$\begin{array}{l}\text { Iron Post Coal Pond } 6 \\
\text { Collected 08/20/85 }\end{array}$} \\
\hline Site & Chlorophyll A & Chlorophyll B & Chlorophyll C \\
\hline 1 & 3.00 & 1.00 & 1.00 \\
\hline 3 & 2.00 & 1.00 & 1.00 \\
\hline 5 & 4.00 & 1.00 & 3.00 \\
\hline 6 & 4.00 & 1.00 & 1.00 \\
\hline 8 & 4.00 & 2.00 & 1.00 \\
\hline 9 & 2.00 & 1.00 & 6.00 \\
\hline Median & 4.00 & 1.00 & 1.00 \\
\hline \multicolumn{4}{|c|}{$\begin{array}{l}\text { Iron Post Coal Pond } 7 \\
\text { Collocted 08/20/85 }\end{array}$} \\
\hline Site & Chlorophyll A & Chlorophyll B & Chlorophyll C \\
\hline 1 & 15.0 & 8.00 & $<1.00$ \\
\hline 2 & 9.00 & 5.00 & $<1.00$ \\
\hline 3 & 6.00 & 6.00 & $<1.00$ \\
\hline 4 & 11.0 & 5.00 & 1.00 \\
\hline Median & 10.0 & 6.00 & $<1.00$ \\
\hline \multicolumn{4}{|c|}{$\begin{array}{l}\text { Iron Post Coal Pond } 8 \\
\text { Collected 08/19/85 }\end{array}$} \\
\hline Site & Chlorophyll A & Chlorophyll B & Chlorophyll C \\
\hline 1 & 7.00 & 2.00 & 5.00 \\
\hline 2 & 3.00 & 1.00 & 5.00 \\
\hline 3 & 2.00 & 1.00 & 3.00 \\
\hline Median & 3.00 & 1.00 & 5.00 \\
\hline \multicolumn{4}{|c|}{$\begin{array}{l}\text { McAlester Coal Pond } 1 \\
\text { Collected 07/18/85 }\end{array}$} \\
\hline Site & Chlorophyll A & Chlorophyll B & Chlorophyll C \\
\hline 1 & 1.00 & 1.00 & $<1.00$ \\
\hline 2 & 9.00 & 2.00 & 1.00 \\
\hline 2 & 6.00 & 2.00 & 1.00 \\
\hline 4 & 2.00 & 1.00 & 1.00 \\
\hline 6 & 5.00 & 2.00 & $<1.00$ \\
\hline 8 & 2.00 & 1.00 & $<1.00$ \\
\hline Median & 4.00 & 2.00 & 1.00 \\
\hline
\end{tabular}


Table 1. - Concentrations of chlorophyll A, B, and C in water samples from study ponds-Continued

\begin{tabular}{cccc}
\hline \multicolumn{4}{c}{$\begin{array}{c}\text { McAlester Coal Pond 2 } \\
\text { Collected 07/30/85 }\end{array}$} \\
\hline Site & Chlorophyll A & Chlorophyll B & Chlorophyll C \\
\hline 1 & 1.00 & $<1.00$ & $<1.00$ \\
3 & 2.00 & $<1.00$ & $<1.00$ \\
7 & 1.00 & 1.00 & $<1.00$ \\
11 & 2.00 & 1.00 & $<1.00$ \\
13 & 3.00 & 1.00 & 1.00 \\
Median & 2.00 & 1.00 & $<1.00$ \\
\hline \hline
\end{tabular}

McAlester Coal Pond 3

Collected 07/30/85

\begin{tabular}{rccc}
\hline Site & Chlorophyll A & Chlorophyll B & Chlorophyll C \\
\hline 1 & $<1.00$ & $<1.00$ & $<1.00$ \\
4 & 1.00 & 1.00 & $<1.00$ \\
6 & 1.00 & $<1.00$ & $<1.00$ \\
8 & $<1.00$ & $<1.00$ & $<1.00$ \\
13 & 2.00 & $<1.00$ & $<1.00$ \\
Median & 1.00 & $<1.00$ & $<1.00$ \\
\hline \hline
\end{tabular}

McAlester Coal Pond 4

Collected 07/23/85

\begin{tabular}{rccc}
\hline Site & Chlorophyll A & Chlorophyll B & Chlorophyll C \\
\hline 3 & 1.00 & 1.00 & $<1.00$ \\
5 & 3.00 & 1.00 & 1.00 \\
6 & $<1.00$ & 1.00 & $<1.00$ \\
7 & 2.00 & 1.00 & $<1.00$ \\
10 & 2.00 & $<1.00$ & $<1.00$ \\
Median & 2.00 & 1.00 & $<1.00$ \\
\hline \hline
\end{tabular}

McAlester Coal Pond 5

Collected 07/24/85

\begin{tabular}{rccc}
\hline Site & Chlorophyll A & Chlorophyll B & Chlorophyll C \\
\hline 2 & $<1.00$ & $<1.00$ & $<1.00$ \\
3 & 1.00 & 1.00 & 1.00 \\
6 & 1.00 & $<1.00$ & 1.00 \\
7 & $<1.00$ & $<1.00$ & $<1.00$ \\
9 & $<1.00$ & $<1.00$ & $<1.00$ \\
12 & $<1.00$ & $<1.00$ & $<1.00$ \\
Median & $<1.00$ & $<1.00$ & $<1.00$ \\
\hline \hline
\end{tabular}


Table 1.-Concentrations of chlorophyll A, B, and C in water samples from study ponds-Continued

\begin{tabular}{|c|c|c|c|}
\hline \multicolumn{4}{|c|}{$\begin{array}{l}\text { McAlester Coal Pond } 6 \\
\text { Collected 07/25/85 }\end{array}$} \\
\hline Site & Chlorophyll A & Chlorophyll B & Chlorophyll C \\
\hline 1 & 3.00 & 2.00 & 3.00 \\
\hline 2 & $<1.00$ & 1.00 & $<1.00$ \\
\hline 3 & 2.00 & 1.00 & 2.00 \\
\hline 6 & 23.0 & 8.00 & $<1.00$ \\
\hline 7 & 7.00 & 2.00 & 1.00 \\
\hline Median & 3.00 & 2.00 & 1.00 \\
\hline \multicolumn{4}{|c|}{$\begin{array}{l}\text { McAlester Coal Pond } 7 \\
\text { Collocted 07/31/85 }\end{array}$} \\
\hline Site & Chlorophyll A & Chlorophyll B & Chlorophyll C \\
\hline 1 & 3.00 & 1.00 & 2.00 \\
\hline 7 & 2.00 & 1.00 & 1.00 \\
\hline 9 & 2.00 & $<1.00$ & $<1.00$ \\
\hline 10 & 2.00 & 1.00 & $<1.00$ \\
\hline Median & 2.00 & 1.00 & $<1.00$ \\
\hline \multirow{2}{*}{\multicolumn{4}{|c|}{$\begin{array}{l}\text { McAlester Coal Pond } 8 \\
\text { Collected 07/31/85 }\end{array}$}} \\
\hline & & & \\
\hline Site & Chlorophyll A & Chlorophyll B & Chlorophyll C \\
\hline 1 & 12.0 & 3.00 & 3.00 \\
\hline 3 & 9.00 & 1.00 & $<1.00$ \\
\hline 7 & 9.00 & 2.00 & 4.00 \\
\hline 11 & 10.0 & 1.00 & 2.00 \\
\hline 12 & 9.00 & 2.00 & 2.00 \\
\hline Median & 9.00 & 2.00 & 2.00 \\
\hline \multirow{2}{*}{\multicolumn{4}{|c|}{$\begin{array}{l}\text { McAlester Coal Pond } 9 \\
\text { Collocted 07/22/85 }\end{array}$}} \\
\hline & & & \\
\hline Site & Chlorophyll A & Chlorophyll B & Chlorophyll C \\
\hline 2 & 2.00 & 1.00 & $<1.00$ \\
\hline 4 & 1.00 & 1.00 & 2.00 \\
\hline 8 & 1.00 & $<1.00$ & $<1.00$ \\
\hline 10 & 2.00 & 1.00 & $<1.00$ \\
\hline 13 & 3.00 & 1.00 & 1.00 \\
\hline 13 & 3.00 & 1.00 & $<1.00$ \\
\hline Median & 2.00 & 1.00 & $<1.00$ \\
\hline
\end{tabular}


Table 10. Vertical profiles of selected sites on study ponds

$\left[\mathrm{mS} / \mathrm{cm}\right.$, microsiemens per centrimeter, ${ }^{\circ} \mathrm{C}$; degrees Celsius; $\mathrm{mg} / \mathrm{L}$, milligrams per liter. The pond name is followed by a site $\mathrm{ID}$, which is the latitude, longitude, and sequence number. The data are from one site per visit. Other vertical profiles were measured and the data are at the U.S. Geological Survey Oklahoma City office]

\begin{tabular}{|c|c|c|c|c|c|c|c|}
\hline $\begin{array}{l}\text { Sampling } \\
\text { date }\end{array}$ & Time & $\begin{array}{c}\text { Depth } \\
\text { (ft) }\end{array}$ & $\begin{array}{c}\text { Specific } \\
\text { conduct- } \\
\text { ance } \\
(\mu S / c m)\end{array}$ & $\begin{array}{c}\text { pH } \\
\text { Water whole } \\
\text { fleld } \\
\text { (standard } \\
\text { units) }\end{array}$ & $\begin{array}{l}\text { Temper- } \\
\text { ature water } \\
\left.\text { ( }{ }^{\circ} \mathrm{C}\right)\end{array}$ & $\begin{array}{c}\text { Transpar- } \\
\text { ency } \\
\text { (Secchi disk) } \\
\text { (in.) }\end{array}$ & $\begin{array}{l}\text { Oxygen, } \\
\text { dissolved } \\
\text { (mgll) }\end{array}$ \\
\hline
\end{tabular}

Control Pond 3 (86, Pond 2), Site 9
351720094430301

April 1985

\begin{tabular}{|c|c|c|c|c|c|c|c|}
\hline 23 & 1047 & 2.00 & 173 & 8.4 & 20.5 & - & 9.9 \\
\hline 23 & 1050 & 4.00 & 173 & 8.4 & 20.0 & -- & 9.9 \\
\hline 23 & 1052 & 6.00 & 173 & 8.3 & 20.0 & -- & 9.6 \\
\hline 23 & 1055 & 8.00 & 174 & 8.2 & 19.0 & -- & 10.4 \\
\hline 23 & 1058 & 10.0 & 175 & 8.0 & 18.5 & -- & 10.4 \\
\hline 23 & 1100 & 12.0 & 178 & 7.8 & 18.0 & -- & 10.0 \\
\hline 23 & 1102 & 14.0 & 184 & 7.7 & 17.0 & -- & 9.8 \\
\hline 23 & 1105 & 16.0 & 190 & 7.7 & 16.5 & - & 9.8 \\
\hline 23 & 1108 & 18.0 & 193 & 7.6 & 13.0 & -- & 9.9 \\
\hline 23 & 1110 & 20.0 & 199 & 7.3 & 10.0 & - & 4.6 \\
\hline 23 & 1115 & 1.00 & 156 & 8.4 & 20.5 & 144 & 9.8 \\
\hline 23 & 1120 & 18.0 & 193 & 7.6 & 13.0 & 144 & 9.9 \\
\hline \multicolumn{8}{|c|}{ July } \\
\hline 25 & 1030 & 0.0 & 103 & 7.3 & 31.0 & 108 & 8.0 \\
\hline 25 & 1031 & 2.00 & 102 & 7.3 & 31.0 & -- & 8.4 \\
\hline 25 & 1032 & 4.00 & 102 & 7.3 & 31.0 & -- & 8.3 \\
\hline 25 & 1033 & 6.00 & 102 & 7.3 & 31.0 & - & 8.3 \\
\hline 25 & 1034 & 8.00 & 102 & 7.3 & 31.0 & -- & 8.3 \\
\hline 25 & 1035 & 10.0 & 102 & 7.2 & 31.0 & -- & 8.2 \\
\hline 25 & 1036 & 12.0 & 102 & 7.0 & 31.0 & -- & 6.3 \\
\hline 25 & 1037 & 14.0 & 109 & 6.5 & 29.0 & -- & 0.4 \\
\hline 25 & 1038 & 16.0 & 114 & 6.3 & 27.0 & -- & 0.1 \\
\hline 25 & 1039 & 18.0 & 131 & 6.2 & 24.0 & -- & 0.2 \\
\hline 25 & 1040 & 2.00 & 102 & 7.3 & 31.0 & 108 & 8.4 \\
\hline 25 & 1041 & 2.00 & 102 & 7.3 & 31.0 & 108 & 8.4 \\
\hline 25 & 1045 & 18.0 & 131 & 6.2 & 24.0 & 108 & 0.2 \\
\hline 25 & 1046 & 18.0 & 131 & 6.2 & 24.0 & 108 & 0.2 \\
\hline
\end{tabular}

\section{Control Pond 4 , Site 3} 363503095231901

May 1985

$\begin{array}{rlllllll}02 & 1215 & 0.0 & 672 & 7.2 & 20.0 & 24.0 & 8.0 \\ 02 & 1216 & 2.00 & 682 & 7.2 & 20.0 & -- & 8.0 \\ 02 & 1217 & 5.00 & 683 & 7.2 & 20.0 & -- & 8.0\end{array}$


Table 10. Vertical profiles of selected sites on study ponds-Continued

\begin{tabular}{|c|c|c|c|c|c|c|c|}
\hline $\begin{array}{l}\text { Sampling } \\
\text { date }\end{array}$ & Time & $\begin{array}{l}\text { Depth } \\
\text { (ft) }\end{array}$ & $\begin{array}{c}\text { Specific } \\
\text { conduct- } \\
\text { ance } \\
(\mu \mathrm{S} / \mathrm{cm})\end{array}$ & $\begin{array}{c}\text { pH } \\
\text { Water whole } \\
\text { field } \\
\text { (standard } \\
\text { units) }\end{array}$ & $\begin{array}{l}\text { Temper- } \\
\text { ature water } \\
\left({ }^{\circ} \mathrm{C}\right)\end{array}$ & $\begin{array}{l}\text { Transpar- } \\
\text { ency } \\
\text { (Secchi disk) } \\
\text { (In.) }\end{array}$ & $\begin{array}{l}\text { Oxygen, } \\
\text { dissolved } \\
\text { (mg/L) }\end{array}$ \\
\hline 02 & 1218 & 10.0 & 684 & 7.9 & 19.5 & - & 7.2 \\
\hline 02 & 1219 & 12.0 & 690 & 7.1 & 19.0 & -- & 7.5 \\
\hline 02 & 1220 & 15.0 & 701 & 7.0 & 16.5 & - & 5.1 \\
\hline 02 & 1221 & 18.0 & 705 & 6.9 & 15.0 & -- & 4.0 \\
\hline 02 & 1222 & 20.0 & 717 & 6.9 & 15.0 & - & 2.5 \\
\hline 02 & 1223 & 25.0 & 737 & 6.9 & 13.0 & -- & 1.4 \\
\hline 02 & 1224 & 29.0 & 752 & 7.0 & 12.5 & -- & 1.2 \\
\hline 02 & 1225 & 10.0 & 684 & 7.2 & 19.5 & 24.0 & 7.9 \\
\hline \multicolumn{8}{|l|}{ August } \\
\hline 16 & 0842 & 0.0 & 128 & 6.8 & 27.5 & 60.0 & 7.9 \\
\hline 16 & 0843 & 3.00 & 129 & 6.8 & 27.5 & -- & 7.9 \\
\hline 16 & 0844 & 6.00 & 130 & 6.8 & 27.5 & -- & 7.9 \\
\hline 16 & 0845 & 9.00 & 130 & 6.8 & 27.5 & -- & 7.9 \\
\hline 16 & 0846 & 12.0 & 135 & 6.6 & 27.0 & -- & 7.6 \\
\hline 16 & 0847 & 15.0 & 135 & 6.7 & 22.5 & -- & 4.4 \\
\hline 16 & 0848 & 26.0 & 137 & 7.5 & 15.0 & -- & 0.6 \\
\hline 16 & 0905 & 3.00 & 130 & 6.8 & 27.5 & 60.0 & 7.9 \\
\hline 16 & 0906 & 26.0 & 137 & 6.8 & 15.0 & 60.0 & 0.6 \\
\hline 16 & 0906 & 3.00 & 130 & 6.8 & 27.5 & 60.0 & 7.9 \\
\hline 16 & 1125 & -- & -- & -- & -- & -- & -- \\
\hline 16 & 1140 & 6.00 & -- & -- & -- & - & -- \\
\hline
\end{tabular}

\section{Control Pond 4, Site 4}

363503095232301

May 1985

Table

$\begin{array}{cccccccc}02 & 1200 & 0.0 & 669 & 7.0 & 20.0 & 24.0 & 8.1 \\ 02 & 1201 & 2.00 & 669 & 7.1 & 20.0 & -- & 8.0 \\ 02 & 1202 & 4.00 & 669 & 7.1 & 20.0 & - & 8.0 \\ 02 & 1203 & 6.00 & 670 & 7.1 & 20.0 & -- & 8.0 \\ 02 & 1204 & 8.00 & 670 & 7.1 & 20.0 & -- & 8.0 \\ 02 & 1205 & 10.0 & 671 & 7.1 & 19.5 & - & 7.8 \\ 02 & 1206 & 12.0 & 676 & 7.1 & 19.5 & - & 6.3 \\ 02 & 1207 & 14.0 & 685 & 7.0 & 17.5 & -- & 5.0 \\ 02 & 1208 & 16.0 & 689 & 6.9 & 16.0 & - & 4.6 \\ 02 & 1209 & 18.0 & 690 & 6.9 & 15.0 & - & 3.4 \\ 02 & 1210 & 20.0 & 697 & 6.9 & 14.5 & -- & 2.6 \\ 02 & 1211 & 22.0 & 707 & 6.9 & 13.5 & - & 2.0 \\ \text { August } & & & & & & & \\ 16 & 0923 & 0.0 & -- & 6.5 & 27.5 & 60.0 & 7.9 \\ 16 & 0924 & 3.00 & - & 6.5 & 27.5 & - & 7.9\end{array}$


Table 10. Vertical profiles of selected sites on study ponds-Continued

\begin{tabular}{|c|c|c|c|c|c|c|c|}
\hline $\begin{array}{l}\text { Sampling } \\
\text { date }\end{array}$ & Tlme & $\begin{array}{l}\text { Depth } \\
\text { (ft) }\end{array}$ & $\begin{array}{c}\text { Specific } \\
\text { conduct- } \\
\text { ance } \\
(\mu \mathrm{S} / \mathrm{cm})\end{array}$ & $\begin{array}{c}\text { pH } \\
\text { Water whole } \\
\text { field } \\
\text { (standard } \\
\text { units) }\end{array}$ & $\begin{array}{l}\text { Temper- } \\
\text { ature water } \\
\text { (') }\end{array}$ & $\begin{array}{l}\text { Transpar- } \\
\text { ency } \\
\text { (Secchi disk) } \\
\text { (in.) }\end{array}$ & $\begin{array}{l}\text { Oxygen, } \\
\text { dissolved } \\
\text { (mg/L) }\end{array}$ \\
\hline 16 & 0925 & 6.00 & - & 6.5 & 27.5 & - & 7.9 \\
\hline 16 & 0927 & 12.0 & -- & 6.3 & 26.5 & -- & 6.2 \\
\hline 16 & 0928 & 15.0 & -- & 6.3 & 22.5 & -- & 4.8 \\
\hline 16 & 0929 & 27.0 & -- & 7.4 & 16.0 & -- & 0.5 \\
\hline 16 & 1205 & 6.00 & -- & -- & -- & -- & -- \\
\hline 16 & 1226 & 9.00 & -- & 6.5 & 27.5 & -- & 7.8 \\
\hline
\end{tabular}

\section{Control Pond 5, Site 2}

363236095240201

August 1985

$\begin{array}{llllllll}16 & 0935 & 0.0 & 30 & 7.3 & 28.0 & 87.0 & 6.8 \\ 16 & 0937 & 2.00 & 29 & 7.4 & 28.0 & - & 6.6 \\ 16 & 0939 & 4.00 & 30 & 7.4 & 28.0 & -- & 6.5 \\ 16 & 0943 & 8.00 & 30 & 7.2 & 28.0 & - & 6.6 \\ 16 & 0945 & 10.0 & 30 & 7.1 & 28.0 & - & 6.5 \\ 16 & 0947 & 12.0 & 32 & 6.8 & 27.0 & - & 1.2 \\ 16 & 0949 & 6.00 & 30 & 7.3 & 28.0 & - & 6.6 \\ 16 & 0950 & 14.0 & 43 & 6.6 & 25.0 & - & 0.5 \\ 16 & 1355 & 7.00 & 29 & 7.2 & 28.0 & -- & 5.6\end{array}$

\section{Control Pond 5, Site 4}

363238095240201

May 1985

$\begin{array}{llll}02 & 0950 & 0.0 & 61 \\ 02 & 0952 & 2.00 & 60 \\ 02 & 0954 & 6.00 & 59 \\ 02 & 0956 & 6.00 & 59 \\ 02 & 0957 & 8.00 & 59 \\ 02 & 0959 & 10.0 & 59 \\ 02 & 1000 & 12.0 & 59 \\ 02 & 1001 & 14.0 & 67 \\ 02 & 1003 & 16.0 & 79 \\ 02 & 1005 & 17.0 & 82\end{array}$

6.9
6.9
6.9
6.9
6.9
6.8
6.7
6.5
6.5
6.5

19.5

66.0

8.0

19.5

7.9

19.5

7.9

19.5

7.9

19.5

7.8

19.0

6.4

16.5

3.1

14.5

$-\quad 1.6$

$\begin{array}{ll}- & 1.6\end{array}$

August

$\begin{array}{ll}16 & 095 \\ 16 & 0956 \\ 16 & 0958 \\ 16 & 1000 \\ 16 & 1002 \\ 16 & 1004 \\ 16 & 1005\end{array}$

$\begin{array}{cc}0.0 & 30 \\ 2.00 & 30 \\ 4.00 & 30 \\ 6.00 & 29 \\ 8.00 & 28 \\ 10.0 & 30 \\ 12.0 & 32\end{array}$

7.4

28.0

28.0

1.6

13.0

$$
-
$$

6.8

6.6

6

6

5.6 
Table 10. Vertical profiles of selected sites on study ponds-Continued

\begin{tabular}{|c|c|c|c|c|c|c|c|}
\hline $\begin{array}{l}\text { Sampling } \\
\text { date }\end{array}$ & Time & $\begin{array}{l}\text { Depth } \\
\text { (ft) }\end{array}$ & $\begin{array}{c}\text { Specific } \\
\text { conduct- } \\
\text { ance } \\
(\mu \mathrm{S} / \mathrm{cm})\end{array}$ & $\begin{array}{c}\text { pH } \\
\text { Water whole } \\
\text { fleld } \\
\text { (standard } \\
\text { units) }\end{array}$ & $\begin{array}{l}\text { Temper- } \\
\text { ature water } \\
\left({ }^{\circ} \mathrm{C}\right)\end{array}$ & $\begin{array}{c}\text { Transpar- } \\
\text { ency } \\
\text { (Secchi disk) } \\
\text { (in.) }\end{array}$ & $\begin{array}{r}\text { Oxygen } \\
\text { dissolve } \\
\text { (mg/L) }\end{array}$ \\
\hline \multicolumn{8}{|c|}{$\begin{array}{c}\text { Control Pond 6, Site } 2 \\
365253095185201\end{array}$} \\
\hline \multicolumn{8}{|l|}{ August 1985} \\
\hline 15 & 1235 & 0.0 & 310 & 6.6 & 27.5 & 48.0 & 12.2 \\
\hline 15 & 1236 & 2.00 & 310 & 6.6 & 27.5 & -- & 12.2 \\
\hline 15 & 1237 & 4.00 & 310 & 6.5 & 27.5 & -- & 12.3 \\
\hline 15 & 1238 & 6.00 & 320 & 6.5 & 27.5 & -- & 12.1 \\
\hline 15 & 1239 & 8.00 & 320 & 6.4 & 27.0 & -- & 12.1 \\
\hline 15 & 1241 & 12.0 & 320 & 6.2 & 27.0 & -- & 12.1 \\
\hline 15 & 1242 & 14.0 & 320 & 6.1 & 27.0 & -- & 11.1 \\
\hline 15 & 1243 & 16.0 & 320 & 5.8 & 26.5 & -- & 6.4 \\
\hline 15 & 1245 & 4.00 & 310 & 6.5 & 27.5 & 48.0 & 12.3 \\
\hline 15 & 1246 & 4.00 & 310 & 6.5 & 27.5 & 48.0 & 12.3 \\
\hline 15 & 1247 & 4.00 & 310 & 6.5 & 27.5 & 48.0 & 12.3 \\
\hline 15 & 1250 & 16.0 & 320 & 5.8 & 27.0 & 48.0 & 6.4 \\
\hline
\end{tabular}

\section{Control Pond 6, Site 3 365253095185401}

May 1985

$\begin{array}{llcl}01 & 1356 & 0.0 & 278 \\ 01 & 1357 & 2.00 & 277 \\ 01 & 1359 & 6.00 & 277 \\ 01 & 1400 & 8.00 & 278 \\ 01 & 1401 & 12.0 & 278 \\ 01 & 1402 & 14.0 & 278 \\ 01 & 1403 & 16.0 & 279 \\ 01 & 1404 & 18.0 & 308 \\ 01 & 1405 & 19.0 & 314 \\ 01 & 1458 & 4.00 & 277\end{array}$

8.3
8.3
8.4
8.4
8.3
8.3
8.3
7.8
7.7
8.3

19.5

36.0

8.8

$-$

8.7

19.5

8.8

$-$

8.8

19.5

8.7

19.5

8.7

19.5

8.7

Croweburg Coal Pond 1, Site 8 360704095433601

April 1985

$\begin{array}{lccc}04 & 1554 & 25.0 & 2980 \\ 04 & 1745 & 0.0 & 1180 \\ 04 & 1747 & 5.00 & 1180 \\ 04 & 1749 & 10.0 & 1500 \\ 04 & 1750 & 15.0 & 1900 \\ 04 & 1752 & 20.0 & 2780\end{array}$

19.5

8.6

17.0

1.4

15.5

0.8

19.5

8.8

August 
Table 10. Vertical profiles of selected sites on study ponds-Continued

\begin{tabular}{|c|c|c|c|c|c|c|c|}
\hline $\begin{array}{l}\text { Sampling } \\
\text { date }\end{array}$ & Time & $\begin{array}{c}\text { Depth } \\
\text { (ft) }\end{array}$ & $\begin{array}{c}\text { Speciflc } \\
\text { conduct- } \\
\text { ance } \\
(\mu \mathrm{S} / \mathrm{cm})\end{array}$ & $\begin{array}{c}\text { pH } \\
\text { Water whole } \\
\text { fleld } \\
\text { (standard } \\
\text { units) }\end{array}$ & $\begin{array}{l}\text { Temper- } \\
\text { ature water } \\
\left({ }^{\circ} \mathrm{C}\right)\end{array}$ & $\begin{array}{c}\text { Transpar- } \\
\text { ency } \\
\text { (Secchi dlak) } \\
\text { (in.) }\end{array}$ & $\begin{array}{c}\text { Oxygen, } \\
\text { dlesolved } \\
\text { (mg/L) }\end{array}$ \\
\hline 13 & 1115 & -- & -- & -- & $=$ & -- & -- \\
\hline 13 & 1250 & 22.0 & 3270 & 6.9 & 17.0 & 15.0 & 0.3 \\
\hline 13 & 1251 & 22.0 & 3270 & 6.9 & 17.0 & 15.0 & 0.3 \\
\hline 13 & 1255 & 4.00 & 1420 & 8.7 & 30.5 & 15.0 & 10.9 \\
\hline 13 & 1256 & 4.00 & 1420 & 8.7 & 30.5 & 15.0 & 10.9 \\
\hline 13 & 1257 & 4.00 & 1420 & 8.7 & 30.5 & 15.0 & 10.9 \\
\hline
\end{tabular}

\section{Croweburg Coal Pond 2, Site 3} 361604095400601

August 1985

$\begin{array}{rrrr}01 & 1235 & 4.00 & 653 \\ 01 & 1240 & 0.0 & 654 \\ 01 & 1241 & 2.00 & 652 \\ 01 & 1242 & 4.00 & 653 \\ 01 & 1243 & 6.00 & 656 \\ 01 & 1244 & 8.00 & 669 \\ 01 & 1245 & 10.0 & 710 \\ 01 & 1246 & 12.0 & 821 \\ 01 & 1247 & 14.0 & 880 \\ 01 & 1248 & 16.0 & 953 \\ 01 & 1249 & 18.0 & 1010\end{array}$

\section{Croweburg Coal Pond 2, Site 4} 361605095400601

April 1985

$\begin{array}{llll}05 & 1400 & 0.0 & 681 \\ 05 & 1401 & 2.00 & 704 \\ 05 & 1402 & 4.00 & 717 \\ 05 & 1403 & 6.00 & 683 \\ 05 & 1404 & 8.00 & 726 \\ 05 & 1405 & 10.0 & 756 \\ 05 & 1406 & 12.0 & 787 \\ 05 & 1407 & 14.0 & 812 \\ 05 & 1408 & 16.0 & 824 \\ 05 & 1409 & 18.0 & 857 \\ 05 & 1410 & 20.0 & 938\end{array}$

8.2
8.1
8.0
8.0
7.9
7.8
7.4
7.4
7.4
7.2
7.2

16.5
16.0
16.0
15.0
13.0
11.0
9.5
9.5
9.0
9.5
9.5

60.0
--
--
--
--
--
--
--
--
--
-

11.0

11.0

11.0

12.2

13.4

9.4

2.7

1.2

0.3

0.2

0.2 
Table 10. Vertical profiles of selected sites on study ponds-Continued

\begin{tabular}{|c|c|c|c|c|c|c|c|}
\hline $\begin{array}{l}\text { Sampling } \\
\text { date }\end{array}$ & Time & $\begin{array}{l}\text { Depth } \\
\text { (ft) }\end{array}$ & $\begin{array}{c}\text { Specific } \\
\text { conduct- } \\
\text { ance } \\
(\mu \mathrm{S} / \mathrm{cm})\end{array}$ & $\begin{array}{c}\text { pH } \\
\text { Water whole } \\
\text { field } \\
\text { (standard } \\
\text { units) }\end{array}$ & $\begin{array}{l}\text { Temper- } \\
\text { ature water } \\
\left({ }^{\circ} \mathrm{C}\right)\end{array}$ & $\begin{array}{l}\text { Transpar- } \\
\text { ency } \\
\text { (Secchi disk) } \\
\text { (in.) }\end{array}$ & $\begin{array}{l}\text { Oxygen, } \\
\text { dissoived } \\
\text { (mg/L) }\end{array}$ \\
\hline \multicolumn{8}{|c|}{$\begin{array}{c}\text { Croweburg Coal Pond 3, Site } 2 \\
362332095365001\end{array}$} \\
\hline \multicolumn{8}{|l|}{ August 1985} \\
\hline 01 & 1030 & 0.0 & 542 & 8.4 & 30.5 & 108 & 8.5 \\
\hline 01 & 1031 & 2.00 & 533 & 8.4 & 30.5 & -- & 8.4 \\
\hline 01 & 1032 & 4.00 & 537 & 8.4 & 30.5 & -- & 8.5 \\
\hline 01 & 1033 & 6.00 & 535 & 8.3 & 30.5 & -- & 8.4 \\
\hline 01 & 1034 & 8.00 & 578 & 8.1 & 30.5 & - & 8.3 \\
\hline 01 & 1035 & 10.0 & 882 & 7.6 & 26.5 & -- & 9.8 \\
\hline 01 & 1036 & 12.0 & 1030 & 7.5 & 23.0 & -- & 5.9 \\
\hline 01 & 1037 & 14.0 & 1150 & 7.6 & 18.0 & - & 4.3 \\
\hline 01 & 1038 & 16.0 & 1280 & 8.1 & 15.0 & - & 3.7 \\
\hline 01 & 1039 & 18.0 & 1320 & 7.7 & 13.0 & -- & 0.6 \\
\hline 01 & 1245 & 10.0 & 882 & 7.6 & 26.5 & - & 9.8 \\
\hline
\end{tabular}

Croweburg Coal Pond 3, Slte 3 362333095365101

April 1985

$\begin{array}{rrrrrrrr}09 & 1131 & 2.00 & 518 & 7.9 & 15.5 & - & 10.7 \\ 09 & 1132 & 4.00 & 520 & 7.9 & 15.5 & -- & 10.7 \\ 09 & 1133 & 6.00 & 525 & 7.7 & 15.0 & -- & 9.5 \\ 09 & 1134 & 8.00 & 546 & 7.5 & 14.0 & -- & 8.4 \\ 09 & 1135 & 10.0 & 579 & 7.4 & 12.5 & -- & 7.7 \\ 09 & 1136 & 12.0 & 631 & 7.2 & 10.5 & -- & 4.6 \\ 09 & 1137 & 14.0 & 719 & 7.1 & 9.5 & -- & 2.4 \\ 09 & 1138 & 16.0 & 858 & 7.1 & 9.0 & -- & 0.5 \\ 09 & 1139 & 18.0 & 962 & 7.0 & 8.5 & -- & 0.3 \\ 09 & 1140 & 20.0 & 1030 & 7.0 & 8.5 & -- & 0.2 \\ 09 & 1141 & 22.0 & -- & 7.0 & -- & -- & 0.2 \\ 09 & 1151 & 2.00 & 518 & 7.9 & 15.5 & 22.0 & 10.7 \\ 09 & 1156 & 20.0 & 1030 & 7.0 & 8.5 & 22.0 & 0.2\end{array}$

Croweburg Coal Pond 4, Site 7 362845095312801

August 1985

07

1115

07

1215

$\begin{array}{ll}-- & - \\ 0.0 & 729 \\ 200 & 729\end{array}$

$--$

$07 \quad 1216$

$2.00 \quad 729$

8.3

8.3

29.0

33.0

10.4

4.00

725

8.3

28.5

10.4

6.00

731

8.3

28.5

10.4

10.2 
Table 10. Vertical profiles of selected sites on study ponds-Continued

\begin{tabular}{|c|c|c|c|c|c|c|c|}
\hline $\begin{array}{l}\text { Sampling } \\
\text { date }\end{array}$ & Time & $\begin{array}{l}\text { Depth } \\
\text { (fi) }\end{array}$ & $\begin{array}{c}\text { Specille } \\
\text { conduct- } \\
\text { ance } \\
(\mu \mathrm{S} / \mathrm{cm})\end{array}$ & $\begin{array}{c}\mathrm{pH} \\
\text { Water whole } \\
\text { field } \\
\text { (standard } \\
\text { units) }\end{array}$ & $\begin{array}{l}\text { Tomper- } \\
\text { ature water } \\
\left({ }^{\circ} \mathrm{C}\right)\end{array}$ & $\begin{array}{l}\text { Transpar- } \\
\text { oncy } \\
\text { (Secchl disk) } \\
\text { (In.) }\end{array}$ & $\begin{array}{l}\text { Oxygen, } \\
\text { dlseolved } \\
\text { (mg/L) }\end{array}$ \\
\hline 07 & 1219 & 8.00 & 733 & 8.2 & 28.0 & - & 10.0 \\
\hline 07 & 1220 & 10.0 & 756 & 8.0 & 28.0 & -- & 9.2 \\
\hline 07 & 1221 & 12.0 & 944 & 7.3 & 25.5 & - & 5.4 \\
\hline 07 & 1222 & 14.0 & 1340 & 7.1 & 22.5 & -- & 1.1 \\
\hline 07 & 1223 & 16.0 & 1460 & 7.0 & 20.0 & -- & 0.5 \\
\hline 07 & 1224 & 18.0 & 1500 & 7.0 & 19.0 & -- & -- \\
\hline 07 & 1230 & 5.00 & 734 & 8.3 & 28.5 & 33.0 & 10.5 \\
\hline 07 & 1231 & 5.00 & 734 & 8.3 & 28.5 & 33.0 & 10.5 \\
\hline 07 & 1232 & 5.00 & 734 & 8.3 & 28.5 & 33.0 & 10.5 \\
\hline 07 & 1235 & 16.0 & 1460 & 7.0 & 20.0 & 33.0 & 0.5 \\
\hline 07 & 1236 & 16.0 & 1460 & 7.0 & 20.0 & 33.0 & 0.5 \\
\hline
\end{tabular}

Croweburg Coal Pond 4, Site 8 362848095312801

April 1985

$\begin{array}{llllllll}08 & 1600 & 0.0 & 883 & 8.1 & 15.0 & 96.0 & 9.8 \\ 08 & 1601 & 2.00 & 885 & 8.1 & 15.0 & - & 9.8 \\ 08 & 1602 & 4.00 & 885 & 8.1 & 15.0 & -- & 9.6 \\ 08 & 1603 & 6.00 & 888 & 8.0 & 15.0 & -- & 9.6 \\ 08 & 1604 & 8.00 & 889 & 8.0 & 15.0 & - & 9.6 \\ 08 & 1605 & 10.0 & 890 & 8.0 & 14.5 & - & 9.2 \\ 08 & 1606 & 12.0 & 893 & 8.0 & 14.5 & - & 9.2 \\ 08 & 1607 & 14.0 & 893 & 8.0 & 14.5 & - & 9.3 \\ 08 & 1608 & 10.0 & 890 & 8.0 & 14.5 & - & 9.2 \\ 08 & 1609 & 18.0 & 924 & 7.6 & 13.5 & - & 6.0 \\ 08 & 1610 & 20.0 & 960 & 7.4 & 12.5 & -- & 1.1 \\ 08 & 1611 & 22.0 & 988 & 7.3 & 11.5 & - & 0.4\end{array}$

\section{Croweburg Coal Pond 5,} Site 1363327095293101

April 1985

$\begin{array}{llll}11 & 1200 & 0.0 & 1770 \\ 11 & 1200 & 0.0 & 1770 \\ 11 & 1202 & 3.00 & 1780 \\ 11 & 1202 & 3.00 & 1780 \\ 11 & 1204 & 6.00 & 1780 \\ 11 & 1204 & 6.00 & 1780 \\ 11 & 1205 & 9.00 & 1780 \\ 11 & 1205 & 9.00 & 1780 \\ 11 & 1206 & 12.0 & 1780\end{array}$

$\begin{array}{rrrr}8.3 & 14.5 & 72.0 & 9.9 \\ 8.3 & 14.5 & 72.0 & 9.9 \\ 8.3 & 14.5 & -- & 9.9 \\ 8.3 & 14.5 & -- & 9.9 \\ 8.3 & 14.0 & -- & 10.0 \\ 8.3 & 14.0 & -- & 10.0 \\ 8.3 & 14.0 & -- & 10.0 \\ 8.3 & 14.0 & -- & 10.0 \\ 8.3 & 14.0 & -- & 9.9\end{array}$


Table 10. Vertical profiles of selected sites on study ponds-Continued

\begin{tabular}{|c|c|c|c|c|c|c|c|}
\hline $\begin{array}{l}\text { Sampling } \\
\text { date }\end{array}$ & Time & $\begin{array}{l}\text { Depth } \\
\text { (ft) }\end{array}$ & $\begin{array}{c}\text { Speclfic } \\
\text { conduct- } \\
\text { ance } \\
(\mu \mathrm{S} / \mathrm{cm})\end{array}$ & $\begin{array}{c}\text { pH } \\
\text { Water whole } \\
\text { field } \\
\text { (standard } \\
\text { unlts) }\end{array}$ & $\begin{array}{c}\text { Temper- } \\
\text { ature water } \\
\left({ }^{\circ} \mathrm{C}\right)\end{array}$ & $\begin{array}{c}\text { Transpar- } \\
\text { ency } \\
\text { (Socchi disk) } \\
\text { (in.) }\end{array}$ & $\begin{array}{l}\text { Oxygen, } \\
\text { dissolved } \\
\text { (mg/L) }\end{array}$ \\
\hline 11 & 1206 & 12.0 & 1780 & 8.3 & 14.0 & - & 9.9 \\
\hline 11 & 1208 & 15.0 & 1790 & 8.3 & 14.0 & - & 9.8 \\
\hline 11 & 1208 & 15.0 & 1790 & 8.3 & 14.0 & - & 9.8 \\
\hline 11 & 1210 & 18.0 & 1800 & 8.3 & 13.5 & - & 9.6 \\
\hline 11 & 1210 & 18.0 & 1800 & 8.3 & 13.5 & -- & 9.6 \\
\hline 11 & 1212 & 21.0 & 1940 & 8.0 & 10.0 & -- & 10.8 \\
\hline 11 & 1212 & 21.0 & 1940 & 8.0 & 10.0 & - & 10.8 \\
\hline 11 & 1214 & 24.0 & 1960 & 8.0 & 9.0 & -- & 12.0 \\
\hline 11 & 1214 & 24.0 & 1960 & 8.0 & 9.0 & -- & 12.0 \\
\hline 11 & 1216 & 27.0 & 2030 & 7.7 & 8.5 & -- & 9.8 \\
\hline 11 & 1216 & 27.0 & 2030 & 7.7 & 8.5 & -- & 9.8 \\
\hline 11 & 1218 & 30.0 & 2410 & 7.4 & 8.5 & -- & 5.8 \\
\hline 11 & 1218 & 30.0 & 2410 & 7.4 & 8.5 & -- & 5.8 \\
\hline 11 & 1220 & 31.0 & -- & 7.2 & 8.5 & -- & 2.2 \\
\hline 11 & 1220 & 31.0 & -- & 7.2 & 8.5 & -- & 2.2 \\
\hline 11 & 1230 & 3.00 & 1780 & 8.3 & 14.5 & 72.0 & 9.9 \\
\hline 11 & 1230 & 3.00 & 1780 & 8.3 & 14.5 & 72.0 & 9.9 \\
\hline 11 & 1245 & 30.0 & 2410 & 7.4 & 8.5 & 72.0 & 5.8 \\
\hline 11 & 1245 & 30.0 & 2410 & 7.4 & 8.5 & 72.0 & 5.8 \\
\hline \multicolumn{8}{|l|}{ August } \\
\hline 14 & 1025 & 0.0 & 1620 & 8.1 & 29.0 & 132 & 8.0 \\
\hline 14 & 1025 & 0.0 & 1620 & 8.1 & 29.0 & 132 & 8.0 \\
\hline 14 & 1026 & 2.00 & 1610 & 8.1 & 29.0 & -- & 8.1 \\
\hline 14 & 1026 & 2.00 & 1610 & 8.1 & 29.0 & -- & 8.1 \\
\hline 14 & 1027 & 4.00 & 1610 & 8.2 & 29.0 & -- & 8.0 \\
\hline 14 & 1027 & 4.00 & 1610 & 8.2 & 29.0 & -- & 8.0 \\
\hline 14 & 1028 & 6.00 & 1610 & 8.2 & 29.0 & -. & 7.9 \\
\hline 14 & 1028 & 6.00 & 1610 & 8.2 & 29.0 & -- & 7.9 \\
\hline 14 & 1029 & 8.00 & 1610 & 8.2 & 29.0 & -- & 8.0 \\
\hline 14 & 1029 & 8.00 & 1610 & 8.2 & 29.0 & -- & 8.0 \\
\hline 14 & 1030 & 10.0 & 1610 & 8.1 & 29.0 & -- & 8.1 \\
\hline 14 & 1030 & 10.0 & 1610 & 8.1 & 29.0 & -- & 8.1 \\
\hline 14 & 1031 & 12.0 & 1610 & 8.2 & 29.0 & - & 8.2 \\
\hline 14 & 1031 & 12.0 & 1610 & 8.2 & 29.0 & - & 8.2 \\
\hline 14 & 1032 & 13.0 & 1610 & 8.2 & 29.0 & - & 8.4 \\
\hline 14 & 1032 & 13.0 & 1610 & 8.2 & 29.0 & -- & 8.4 \\
\hline 14 & 1033 & 14.0 & 1610 & 8.2 & 29.0 & - & 8.3 \\
\hline 14 & 1033 & 14.0 & 1610 & 8.2 & 29.0 & -- & 8.3 \\
\hline 14 & 1034 & 16.0 & 1680 & 7.8 & 28.5 & -- & 7.7 \\
\hline 14 & 1034 & 16.0 & 1680 & 7.8 & 28.5 & -. & 7.7 \\
\hline
\end{tabular}


Table 10. Vertical profiles of selected sites on study ponds-Continued

\begin{tabular}{cccccccc}
\hline $\begin{array}{c}\text { Sampling } \\
\text { date }\end{array}$ & Time & $\begin{array}{c}\text { Depth } \\
\text { (ft) }\end{array}$ & $\begin{array}{c}\text { Speciflc } \\
\text { conduct- } \\
\text { ance } \\
(\mu \mathbf{S} / \mathbf{c m})\end{array}$ & $\begin{array}{c}\text { PH } \\
\text { Water whole } \\
\text { fleld } \\
\text { (standard } \\
\text { unlts) }\end{array}$ & $\begin{array}{c}\text { Temper- } \\
\text { ature water } \\
\left({ }^{\circ} \text { C) }\right.\end{array}$ & $\begin{array}{c}\text { Transpar- } \\
\text { ency } \\
\text { (Secchl dlsk) } \\
\text { (in.) }\end{array}$ & $\begin{array}{c}\text { Oxygen, } \\
\text { dissolved } \\
\text { (mg/L) }\end{array}$ \\
\hline 14 & 1035 & 18.0 & 1910 & 7.4 & 26.5 & -- & 7.0 \\
14 & 1035 & 18.0 & 1910 & 7.4 & 26.5 & -- & 7.0 \\
14 & 1036 & 28.0 & 3470 & 6.9 & 15.5 & -- & 1.7 \\
14 & 1036 & 28.0 & 3470 & 6.9 & 15.5 & -- & 1.7 \\
14 & 1040 & 13.0 & 1610 & 8.2 & 29.0 & 132 & 8.4 \\
14 & 1040 & 13.0 & 1610 & 8.2 & 29.0 & 132 & 8.4 \\
14 & 1041 & 13.0 & 1610 & 8.2 & 29.0 & 132 & 8.4 \\
14 & 1041 & 13.0 & 1610 & 8.2 & 29.0 & 132 & 8.4 \\
14 & 1045 & 28.0 & 3470 & 6.9 & 15.5 & 132 & 1.7 \\
14 & 1045 & 28.0 & 3470 & 6.9 & 15.5 & 132 & 1.7 \\
14 & 1046 & 28.0 & 3470 & 6.9 & 15.5 & 132 & 1.7 \\
14 & 1046 & 28.0 & 3470 & 6.9 & 15.5 & 132 & 1.7 \\
14 & 1047 & 13.0 & 1610 & 8.2 & 29.0 & 132 & 8.4 \\
14 & 1047 & 13.0 & 1610 & 8.2 & 29.0 & 132 & 8.4
\end{tabular}

\section{Croweburg Coal Pond 6, Slte 3} 363647095251401

May 1985

$\begin{array}{llllllll}08 & 1500 & 0.0102 & 8.5 & 23.0 & 63.0 & 8.8 & \\ 08 & 1502 & 3.00 & 350 & 8.5 & 22.5 & -- & 8.7 \\ 08 & 1504 & 6.00 & 350 & 8.5 & 22.0 & -- & 8.8 \\ 08 & 1506 & 9.00 & 349 & 8.5 & 21.5 & -- & 8.7 \\ 08 & 1508 & 12.0 & 352 & 8.3 & 20.5 & -- & 7.9 \\ 08 & 1510 & 15.0 & 354 & 8.5 & 17.0 & -- & 9.2 \\ 08 & 1511 & 16.0 & -- & 8.5 & -- & -- & 9.0 \\ 08 & 1512 & 18.0 & 357 & 8.5 & 14.5 & -- & 8.9 \\ 08 & 1514 & 21.0 & 360 & 8.1 & 13.0 & -- & 5.6 \\ 08 & 1516 & 24.0 & 364 & 7.9 & 11.5 & -- & 2.4 \\ 08 & 1518 & 27.0 & 367 & 7.6 & 10.5 & -- & 1.4 \\ 08 & 1520 & 28.0 & 372 & 7.6 & 10.5 & -- & 1.4\end{array}$

\section{Croweburg Coal Pond 6, Site 6} 363650095251801

August 1985

$\begin{array}{llllllll}13 & 1100 & - & -- & - & -- & - & - \\ 13 & 1105 & 0.0 & 379 & 8.0 & 29.0 & 36.0 & 12.7 \\ 13 & 1106 & 4.00 & 377 & 8.0 & 29.0 & -- & 12.5 \\ 13 & 1107 & 8.00 & 376 & 8.0 & 29.0 & -- & 12.4 \\ 13 & 1108 & 9.00 & 376 & 8.0 & 29.0 & -- & 12.3 \\ 13 & 1109 & 10.0 & 378 & 7.8 & 28.5 & -- & 10.5\end{array}$


Table 10. Vertical profiles of selected sites on study ponds-Continued

\begin{tabular}{|c|c|c|c|c|c|c|c|}
\hline $\begin{array}{l}\text { Sampllng } \\
\text { date }\end{array}$ & Tlme & $\begin{array}{l}\text { Depth } \\
\text { (ft) }\end{array}$ & $\begin{array}{c}\text { Speclfic } \\
\text { conduct- } \\
\text { ance } \\
(\mu S / \mathrm{cm})\end{array}$ & $\begin{array}{c}\text { pH } \\
\text { Water whole } \\
\text { fleld } \\
\text { (standard } \\
\text { units) }\end{array}$ & $\begin{array}{l}\text { Temper- } \\
\text { ature water } \\
\left({ }^{\circ} \mathrm{C}\right)\end{array}$ & $\begin{array}{l}\text { Transpar- } \\
\text { ency } \\
\text { (Secchl disk) } \\
\text { (In.) }\end{array}$ & $\begin{array}{l}\text { Oxygen, } \\
\text { dissolved } \\
\text { (mg/L) }\end{array}$ \\
\hline 13 & 1110 & 12.0 & 379 & 7.7 & 26.0 & - & 5.3 \\
\hline 13 & 1111 & 16.0 & 388 & 7.9 & 19.0 & - & 4.5 \\
\hline 13 & 1112 & 20.0 & 394 & 8.4 & 15.5 & - & 4.4 \\
\hline 13 & 1114 & 24.0 & 398 & 8.8 & 13.0 & -. & 4.6 \\
\hline 13 & 1116 & 26.0 & 390 & 8.7 & 12.5 & -- & 4.5 \\
\hline 13 & 1118 & 24.0 & 398 & 8.8 & 13.0 & 36.0 & 4.6 \\
\hline 13 & 1120 & 4.00 & 377 & 8.0 & 29.0 & 36.0 & 12.5 \\
\hline 13 & 1121 & 4.00 & 377 & 8.0 & 29.0 & 36.0 & 12.5 \\
\hline 13 & 1215 & 4.00 & 377 & 8.0 & 29.0 & 36.0 & 12.5 \\
\hline
\end{tabular}

Croweburg Coal Pond 7, Site 9 364754095174201

May 1985

$\begin{array}{cccccccc}16 & 1500 & 0.0 & 258 & 7.9 & 21.5 & 12.0 & 8.3 \\ 16 & 1501 & 2.00 & 258 & 7.9 & 21.5 & -- & 8.4 \\ 16 & 1502 & 4.00 & 257 & 7.9 & 21.5 & -- & 8.4 \\ 16 & 1503 & 6.00 & 254 & 7.8 & 19.0 & -- & 7.4 \\ 16 & 1504 & 8.00 & 252 & 7.4 & 17.0 & -- & 4.4 \\ 16 & 1505 & 10.0 & 250 & 7.2 & 13.5 & -- & 2.5 \\ 16 & 1506 & 12.0 & 253 & 7.2 & 13.0 & -- & 1.8 \\ 16 & 1507 & 14.0 & 254 & 7.2 & 12.5 & -- & 1.6 \\ 16 & 1508 & 16.0 & 256 & 7.0 & 12.0 & -- & 1.5 \\ 16 & 1509 & 18.0 & 258 & 7.0 & 11.5 & - & 1.5 \\ 16 & 1510 & 20.0 & 262 & 7.1 & 11.5 & -- & 1.3 \\ 16 & 1511 & 22.0 & 263 & 7.1 & 11.5 & - & 1.3 \\ 16 & 1512 & 24.0 & 265 & 7.1 & 11.5 & - & 1.3 \\ 16 & 1513 & 26.0 & 270 & 7.1 & 11.0 & -- & 1.3 \\ 16 & 1515 & 10.0 & 250 & 7.2 & 13.5 & 12.0 & 2.5 \\ \text { August } & & & & & & & \\ 21 & 1200 & -- & -- & -- & -- & -- & -- \\ 21 & 1215 & 0.0 & 255 & 8.1 & 27.5 & 30.0 & 8.4 \\ 21 & 1216 & 2.00 & 256 & 8.1 & 27.5 & -- & 8.3 \\ 21 & 1217 & 4.00 & 256 & 8.1 & 27.0 & -- & 8.4 \\ 21 & 1218 & 6.00 & 255 & 8.1 & 27.0 & -- & 8.4 \\ 21 & 1219 & 8.00 & 255 & 8.1 & 26.5 & -- & 8.2 \\ 21 & 1220 & 10.0 & 261 & 7.5 & 25.5 & - & 4.6 \\ 21 & 1221 & 12.0 & 289 & 7.3 & 21.0 & -- & 0.6 \\ 21 & 1222 & 14.0 & 293 & 7.1 & 17.5 & -- & 0.5 \\ 21 & 1223 & 16.0 & 298 & 7.0 & 14.5 & - & 0.4 \\ 21 & 1224 & 18.0 & 302 & 7.0 & 13.0 & -- & 0.4\end{array}$


Table 10. Vertical profiles of selected sites on study ponds-Continued

\begin{tabular}{cccccccc}
\hline $\begin{array}{c}\text { Sampling } \\
\text { date }\end{array}$ & Time & $\begin{array}{c}\text { Depth } \\
\text { (ft) }\end{array}$ & $\begin{array}{c}\text { Speclfic } \\
\text { conduct- } \\
\text { ance } \\
(\mu \mathbf{S} / \mathbf{c m})\end{array}$ & $\begin{array}{c}\text { Water whole } \\
\text { field } \\
\text { (standard } \\
\text { unlts) }\end{array}$ & $\begin{array}{c}\text { Temper- } \\
\text { ature water } \\
\left({ }^{\circ} \mathrm{C}\right)\end{array}$ & $\begin{array}{c}\text { Transpar- } \\
\text { ency } \\
\text { (Sochl dlsk) } \\
\text { (In.) }\end{array}$ & $\begin{array}{c}\text { Oxygen, } \\
\text { diseolved } \\
\text { (mg/L) }\end{array}$ \\
\hline 21 & 1225 & 20.0 & 307 & 7.1 & 12.5 & -- & 0.3 \\
21 & 1226 & 22.0 & 313 & 7.1 & 12.5 & -- & 0.3 \\
21 & 1227 & 24.0 & 319 & 7.1 & 12.0 & -- & 0.3 \\
21 & 1235 & 22.0 & 313 & 7.1 & 12.5 & 30.0 & 0.3 \\
21 & 1236 & 22.0 & 313 & 7.1 & 12.5 & 30.0 & 0.3 \\
21 & 1240 & 6.00 & 255 & 8.1 & 27.0 & 30.0 & 8.4 \\
21 & 1241 & 6.00 & 255 & 8.1 & 27.0 & 30.0 & 8.4 \\
21 & 1242 & 6.00 & 255 & 8.1 & 27.0 & 30.0 & 8.4
\end{tabular}

\section{Croweburg Coal Pond 8, Site 2} 365427095124001

August 1985

$\begin{array}{llllllll}15 & 1120 & - & -- & -- & - & - & - \\ 15 & 1220 & 0.0 & 656 & 7.2 & 29.0 & 45.0 & 7.1 \\ 15 & 1221 & 2.00 & 653 & 7.1 & 29.0 & -- & 7.7 \\ 15 & 1222 & 4.00 & 650 & 6.1 & 28.5 & -- & 7.3 \\ 15 & 1223 & 6.00 & 647 & 6.1 & 28.5 & -- & 7.2 \\ 15 & 1224 & 8.00 & 647 & 7.0 & 28.0 & -- & 7.1 \\ 15 & 1225 & 10.0 & 646 & 6.9 & 28.0 & -- & 7.0 \\ 15 & 1226 & 12.0 & 669 & 6.1 & 27.0 & -- & 4.0 \\ 15 & 1227 & 14.0 & 701 & 6.2 & 23.0 & -- & 1.1 \\ 15 & 1228 & 16.0 & 820 & 6.3 & 21.0 & -- & 0.8 \\ 15 & 1229 & 18.0 & 968 & 6.3 & 19.0 & -- & 0.3 \\ 15 & 1230 & 2.00 & 653 & 7.1 & 29.0 & 45.0 & 7.7 \\ 15 & 1231 & 2.00 & 653 & 7.1 & 29.0 & 45.0 & 7.7 \\ 15 & 1232 & 2.00 & 653 & 7.1 & 29.0 & 45.0 & 7.7 \\ 15 & 1235 & 18.0 & 968 & 6.3 & 19.0 & 45.0 & 0.3 \\ 15 & 1236 & 18.0 & 968 & 6.3 & 19.0 & 45.0 & 0.3\end{array}$

\section{Croweburg Coal Pond 8, Site 5 365433095124101}

May 1985

$\begin{array}{llllllll}16 & 1150 & 0.0 & 615 & 7.3 & 21.5 & 84.0 & 8.2 \\ 16 & 1151 & 2.00 & 616 & 7.3 & 21.5 & - & 8.2 \\ 16 & 1152 & 4.00 & 616 & 7.3 & 21.5 & -- & 8.2 \\ 16 & 1153 & 6.00 & 616 & 7.2 & 21.5 & - & 8.2 \\ 16 & 1154 & 8.00 & 616 & 7.3 & 21.5 & - & 8.2 \\ 16 & 1155 & 10.0 & 616 & 7.2 & 21.5 & - & 8.2 \\ 16 & 1156 & 12.0 & 617 & 7.1 & 21.0 & - & 7.8 \\ 16 & 1157 & 14.0 & 614 & 7.1 & 20.5 & - & 7.6\end{array}$


Table 10. Vertical profiles of selected sites on study ponds-Continued

\begin{tabular}{cccccccc}
\hline $\begin{array}{c}\text { Sampling } \\
\text { date }\end{array}$ & Time & $\begin{array}{c}\text { Depth } \\
(\mathbf{f t})\end{array}$ & $\begin{array}{c}\text { Specific } \\
\text { conduct- } \\
\text { ance } \\
(\mu \mathrm{S} / \mathbf{c m})\end{array}$ & $\begin{array}{c}\text { Water whole } \\
\text { fleld } \\
\text { (standard } \\
\text { units) }\end{array}$ & $\begin{array}{c}\text { Temper- } \\
\text { ature water } \\
\left({ }^{\circ} \mathrm{C}\right)\end{array}$ & $\begin{array}{c}\text { Transpar- } \\
\text { ency } \\
\text { (Secchi disk) } \\
\text { (in.) }\end{array}$ & $\begin{array}{c}\text { Oxygen, } \\
\text { dissolved } \\
\text { (mg/L) }\end{array}$ \\
\hline 16 & 1158 & 16.0 & 614 & 7.0 & 20.5 & -- & 7.4 \\
16 & 1159 & 18.0 & 623 & 7.0 & 19.5 & - & 6.9 \\
16 & 1200 & 20.0 & 827 & 6.5 & 17.0 & - & 2.4 \\
16 & 1205 & 6.00 & 616 & 7.2 & 21.5 & 84.0 & 8.2
\end{tabular}

Iron Post Coal Pond 1, Site 5

363021095325201

May 1985

$\begin{array}{lccccccc}06 & 1415 & 0.0 & 2170 & 8.4 & 22.5 & 75.0 & 12.0 \\ 06 & 1416 & 2.00 & 2170 & 8.4 & 22.5 & -- & 12.2 \\ 06 & 1417 & 4.00 & 2190 & 8.4 & 21.5 & -- & 13.0 \\ 06 & 1418 & 6.00 & 2230 & 8.3 & 20.5 & -- & 12.5 \\ 06 & 1419 & 8.00 & 2240 & 8.3 & 20.0 & -- & 12.4 \\ 06 & 1420 & 10.0 & 2240 & 8.2 & 19.5 & -- & 12.2 \\ 06 & 1421 & 12.0 & 2250 & 8.2 & 19.5 & -- & 12.2 \\ 06 & 1422 & 14.0 & 2270 & 7.8 & 19.0 & -- & 5.0 \\ 06 & 1423 & 15.0 & 2310 & 7.5 & 18.5 & -- & 2.4 \\ 06 & 1425 & 14.0 & 2270 & 7.8 & 19.0 & 75.0 & 5.0 \\ 06 & 1430 & 4.00 & 2190 & 8.4 & 21.5 & 75.0 & 13.0\end{array}$

Iron Post Coal Pond 1, Site 4 363022095325101

August 1985

$\begin{array}{llllllll}08 & 1025 & 0.0 & 2580 & 7.9 & 30.0 & 48.0 & 7.7 \\ 08 & 1027 & 2.00 & 2580 & 7.9 & 30.0 & -- & 7.6 \\ 08 & 1029 & 4.00 & 2580 & 7.9 & 30.0 & - & 7.5 \\ 08 & 1031 & 6.00 & 2590 & 7.8 & 30.0 & -- & 7.2 \\ 08 & 1032 & 8.00 & 2590 & 7.5 & 29.5 & - & 4.2 \\ 08 & 1033 & 10.0 & 2590 & 7.2 & 28.0 & -- & 0.6 \\ 08 & 1034 & 12.0 & 2590 & 7.0 & 25.5 & -- & 0.5 \\ 08 & 1200 & 4.00 & 2570 & 7.9 & 30.0 & 48.0 & 7.5\end{array}$

Iron Post Coal Pond 2, Site 4 362832095343101

May 1985

$\begin{array}{lccccccc}02 & 1507 & 16.0 & 1320 & 7.4 & 18.5 & 48.0 & 6.1 \\ 02 & 1508 & 2.00 & 1160 & 7.5 & 20.5 & - & 7.9 \\ 02 & 1509 & 4.00 & 1170 & 7.5 & 20.5 & -- & 7.7 \\ 02 & 1510 & 6.00 & 1170 & 7.5 & 20.0 & -- & 7.5 \\ 02 & 1511 & 8.00 & 1170 & 7.5 & 20.0 & -- & 7.4\end{array}$


Table 10. Vertical profiles of selected sites on study ponds-Continued

\begin{tabular}{|c|c|c|c|c|c|c|c|}
\hline $\begin{array}{l}\text { Sampling } \\
\text { date }\end{array}$ & Time & $\begin{array}{l}\text { Depth } \\
\text { (ft) }\end{array}$ & $\begin{array}{c}\text { Specific } \\
\text { conduct- } \\
\text { ance } \\
(\mu S / \mathrm{cm})\end{array}$ & $\begin{array}{c}\text { pH } \\
\text { Water whole } \\
\text { fleld } \\
\text { (standard } \\
\text { unlts) }\end{array}$ & $\begin{array}{l}\text { Temper- } \\
\text { ature water } \\
\left({ }^{\circ} \mathrm{C}\right)\end{array}$ & $\begin{array}{l}\text { Transpar- } \\
\text { ency } \\
\text { (Secchi dlsk) } \\
\text { (In.) }\end{array}$ & $\begin{array}{l}\text { Oxygen, } \\
\text { dissolved } \\
\text { (mg/L) }\end{array}$ \\
\hline 02 & 1512 & 10.0 & 1170 & 7.5 & 19.5 & - & 7.3 \\
\hline 02 & 1513 & 12.0 & 1190 & 7.5 & 19.0 & - & 6.9 \\
\hline 02 & 1514 & 14.0 & 1220 & 7.4 & 18.5 & -- & 6.5 \\
\hline 02 & 1515 & 16.0 & 1320 & 7.4 & 18.5 & - & 6.1 \\
\hline 02 & 1516 & 18.0 & 1350 & 7.3 & 17.5 & -- & 5.3 \\
\hline 02 & 1517 & 20.0 & 1700 & 7.2 & 16.5 & -- & 3.7 \\
\hline 02 & 1518 & 21.0 & 1910 & 7.2 & 16.0 & -- & 3.2 \\
\hline 02 & 1520 & 20.0 & 1700 & 7.2 & 16.5 & 48.0 & 3.7 \\
\hline 02 & 1525 & 4.00 & 1170 & 7.5 & 20.5 & 48.0 & 7.7 \\
\hline \multicolumn{8}{|l|}{ August } \\
\hline 12 & 1330 & 20.0 & 2110 & 7.3 & 24.0 & 48.0 & -- \\
\hline 12 & 1331 & 20.0 & 2110 & 7.3 & 24.0 & 48.0 & -. \\
\hline 12 & 1335 & 6.00 & 1800 & 7.9 & 29.0 & 48.0 & 7.1 \\
\hline
\end{tabular}

Iron Post Coal Pond 2, Site 1

362833095343001

August 1985

$\begin{array}{ll}12 & 1300 \\ 12 & 1301 \\ 12 & 1302 \\ 12 & 1303 \\ 12 & 1304 \\ 12 & 1305 \\ 12 & 1306 \\ 12 & 1307 \\ 12 & 1308 \\ 12 & 1309 \\ 12 & 1315\end{array}$

$\begin{array}{cc}0.0 & 1790 \\ 2.00 & 1790 \\ 4.00 & 1790 \\ 6.00 & 1790 \\ 8.00 & 1790 \\ 10.0 & 1790 \\ 12.0 & 1790 \\ 14.0 & 1940 \\ 16.0 & 2080 \\ 18.0 & 2050 \\ 6.00 & 1790\end{array}$

7.9

7.9

7.9

7.9

7.9

7.6

7.3

7.3

7.3

7.2

7.9
29.5

29.5

29.5

29.5

29.0

29.0

27.5

27.5

27.0

25.0

29.5
45.0

$-$

$-$

$-$

$-$

$-$

$-$

$-$

$-$

$-$

$-$

$-$

$-$
6.9

6.9

6.9

7.0

6.8

5.2

1.2

1.8

1.8

1.3

7.0

Iron Post Coal Pond 3, Site 6 362648095334101

April 1985

$\begin{array}{llllllll}09 & 1500 & 0.0 & 446 & 7.7 & 15.5 & 6.00 & 9.5 \\ 09 & 1500 & 0.0 & 446 & 7.7 & 15.5 & 6.00 & 9.5 \\ 09 & 1501 & 2.00 & 451 & 7.7 & 15.5 & -- & 9.5 \\ 09 & 1501 & 2.00 & 451 & 7.7 & 15.5 & -- & 9.5 \\ 09 & 1502 & 4.00 & 442 & 7.7 & 14.0 & -- & 9.5 \\ 09 & 1502 & 4.00 & 442 & 7.7 & 14.0 & -- & 9.5 \\ 09 & 1503 & 6.00 & 445 & 7.7 & 12.5 & -- & 9.2 \\ 09 & 1503 & 6.00 & 445 & 7.7 & 12.5 & -- & 9.2\end{array}$


Table 10. Vertical profiles of selected sites on study ponds-Continued

\begin{tabular}{|c|c|c|c|c|c|c|c|}
\hline $\begin{array}{l}\text { Sampling } \\
\text { date }\end{array}$ & Time & $\begin{array}{l}\text { Depth } \\
\text { (ft) }\end{array}$ & $\begin{array}{c}\text { Specific } \\
\text { conduct- } \\
\text { ance } \\
(\mu \mathrm{S} / \mathrm{cm})\end{array}$ & $\begin{array}{c}\text { pH } \\
\text { Water whole } \\
\text { field } \\
\text { (standard } \\
\text { units) }\end{array}$ & $\begin{array}{l}\text { Temper- } \\
\text { ature water } \\
\left({ }^{\circ} \mathrm{C}\right)\end{array}$ & $\begin{array}{l}\text { Transpar- } \\
\text { ency } \\
\text { (Secchi disk) } \\
\text { (In.) }\end{array}$ & $\begin{array}{c}\text { Oxygen, } \\
\text { dissoived } \\
\text { (mg/L) }\end{array}$ \\
\hline 09 & 1504 & 8.00 & 457 & 7.7 & 12.5 & - & 9.0 \\
\hline 09 & 1504 & 8.00 & 457 & 7.7 & 12.5 & -- & 9.0 \\
\hline 09 & 1505 & 10.0 & 460 & 7.6 & 12.0 & -- & 9.0 \\
\hline 09 & 1505 & 10.0 & 460 & 7.6 & 12.0 & -- & 9.0 \\
\hline 09 & 1506 & 12.0 & 464 & 7.6 & 12.0 & -- & 8.9 \\
\hline 09 & 1506 & 12.0 & 464 & 7.6 & 12.0 & -- & 8.9 \\
\hline 09 & 1507 & 13.0 & 470 & 7.6 & 12.0 & -- & 8.7 \\
\hline 09 & 1507 & 13.0 & 470 & 7.6 & 12.0 & - & 8.7 \\
\hline \multicolumn{8}{|l|}{ August } \\
\hline 12 & 1335 & 0.0 & 382 & 8.5 & 30.0 & 30.0 & 12.2 \\
\hline 12 & 1335 & 0.0 & 382 & 8.5 & 30.0 & 30.0 & 12.2 \\
\hline 12 & 1336 & 2.00 & 382 & 8.5 & 29.5 & -- & 12.2 \\
\hline 12 & 1336 & 2.00 & 382 & 8.5 & 29.5 & -- & 12.2 \\
\hline 12 & 1337 & 3.00 & 382 & 8.5 & 29.5 & -- & 12.2 \\
\hline 12 & 1337 & 3.00 & 382 & 8.5 & 29.5 & -- & 12.2 \\
\hline 12 & 1338 & 4.00 & 382 & 8.4 & 29.5 & -- & 12.2 \\
\hline 12 & 1338 & 4.00 & 382 & 8.4 & 29.5 & -- & 12.2 \\
\hline 12 & 1339 & 5.00 & 383 & 8.4 & 29.5 & -- & 11.9 \\
\hline 12 & 1339 & 5.00 & 383 & 8.4 & 29.5 & -- & 11.9 \\
\hline 12 & 1340 & 6.00 & 384 & 8.4 & 29.0 & -- & 11.7 \\
\hline 12 & 1340 & 6.00 & 384 & 8.4 & 29.0 & -- & 11.7 \\
\hline 12 & 1341 & 8.00 & 385 & 8.0 & 27.0 & -- & 4.9 \\
\hline 12 & 1341 & 8.00 & 385 & 8.0 & 27.0 & -- & 4.9 \\
\hline 12 & 1342 & 10.0 & 388 & 7.8 & 26.0 & -- & 3.4 \\
\hline 12 & 1342 & 10.0 & 388 & 7.8 & 26.0 & -- & 3.4 \\
\hline 12 & 1345 & 4.00 & 382 & 8.4 & 29.5 & - & 12.2 \\
\hline 12 & 1345 & 4.00 & 382 & 8.4 & 29.5 & -- & 12.2 \\
\hline
\end{tabular}

\section{Iron Post Coal Pond 4, Site 1}

362632095350201

August 1985

$\begin{array}{lccccccc}06 & 1050 & - & -- & - & -- & - & - \\ 06 & 1100 & 14.0 & 1200 & 7.2 & 18.0 & 30.0 & 0.5 \\ 06 & 1105 & 0.0 & 1100 & 7.9 & 28.5 & 30.0 & 8.8 \\ 06 & 1106 & 2.00 & 1100 & 7.9 & 28.5 & - & 8.8 \\ 06 & 1107 & 4.00 & 1100 & 7.9 & 28.5 & - & 8.7 \\ 06 & 1108 & 6.00 & 1100 & 7.8 & 28.0 & - & 8.4 \\ 06 & 1109 & 8.00 & 1120 & 7.4 & 27.0 & -- & 5.3 \\ 06 & 1110 & 10.0 & 1150 & 7.1 & 24.5 & - & 1.4 \\ 06 & 1111 & 12.0 & 1200 & 7.1 & 21.5 & - & 0.5\end{array}$


Table 10. Vertical profiles of selected sites on study ponds-Continued

\begin{tabular}{|c|c|c|c|c|c|c|c|}
\hline $\begin{array}{l}\text { Samplling } \\
\text { date }\end{array}$ & Tlime & $\begin{array}{l}\text { Depth } \\
\text { (ft) }\end{array}$ & $\begin{array}{c}\text { Specific } \\
\text { conduct- } \\
\text { ance } \\
(\mu \mathrm{S} / \mathrm{cm})\end{array}$ & $\begin{array}{c}\text { pH } \\
\text { Water whole } \\
\text { field } \\
\text { (standard } \\
\text { units) }\end{array}$ & $\begin{array}{l}\text { Temper- } \\
\text { ature water } \\
\left({ }^{\circ} \mathrm{C}\right)\end{array}$ & $\begin{array}{c}\text { Transpar- } \\
\text { oncy } \\
\text { (Secchi disk) } \\
\text { (in.) }\end{array}$ & $\begin{array}{l}\text { Oxygen, } \\
\text { dissolved } \\
\text { (mg/L) }\end{array}$ \\
\hline 06 & 1112 & 14.0 & 1200 & 7.2 & 18.0 & - & 0.5 \\
\hline 06 & 1113 & 16.0 & 1210 & 7.4 & 16.0 & - & 0.4 \\
\hline 06 & 1120 & 4.00 & 1100 & 7.9 & 28.5 & 30.0 & 8.7 \\
\hline 06 & 1121 & 4.00 & 1100 & 7.9 & 28.5 & 30.0 & 8.7 \\
\hline 06 & 1122 & 6.00 & 1100 & 7.8 & 28.0 & 30.0 & 8.4 \\
\hline
\end{tabular}

Iron Post Coal Pond 4, Site 2 362634095350201

May 1985

$\begin{array}{lccccccc}14 & 1410 & 0.0 & 954 & 7.8 & 21.0 & 26.0 & 7.5 \\ 14 & 1411 & 2.00 & 958 & 7.8 & 21.0 & -- & 7.5 \\ 14 & 1412 & 4.00 & 960 & 7.8 & 21.0 & -- & 7.4 \\ 14 & 1413 & 6.00 & 961 & 7.8 & 21.0 & -- & 7.4 \\ 14 & 1414 & 8.00 & 986 & 7.4 & 20.5 & -- & 4.0 \\ 14 & 1415 & 10.0 & 978 & 7.3 & 18.0 & -- & 1.5 \\ 14 & 1416 & 12.0 & 1080 & 7.3 & 14.5 & -- & 1.4 \\ 14 & 1417 & 14.0 & 1130 & 7.4 & 13.0 & - & 1.4 \\ 14 & 1418 & 16.0 & 1180 & 7.4 & 12.0 & - & 1.4 \\ 14 & 1419 & 18.0 & 1220 & 7.4 & 11.0 & - & 1.4 \\ 14 & 1430 & 2.00 & 958 & 7.8 & 21.0 & 26.0 & 7.5 \\ 14 & 1435 & 16.0 & 1180 & 7.4 & 12.0 & 26.0 & 1.4\end{array}$

Iron Post Coal Pond 5, Site 2 362609095342301

May 1985

$\begin{array}{cccccccc}10 & 1020 & 0.0 & 948 & 7.7 & 20.0 & 84.0 & 7.9 \\ 10 & 1022 & 2.00 & 947 & 7.7 & 20.0 & -- & 8.0 \\ 10 & 1024 & 4.00 & 947 & 7.7 & 20.0 & -- & 8.0 \\ 10 & 1026 & 6.00 & 1170 & 7.5 & 19.0 & -- & 6.9 \\ 10 & 1027 & 8.00 & 1300 & 7.4 & 17.5 & -- & 5.9 \\ 10 & 1028 & 10.0 & 1380 & 7.3 & 16.5 & -- & 3.7 \\ 10 & 1029 & 12.0 & 1430 & 7.3 & 15.5 & - & 2.1 \\ 10 & 1030 & 13.0 & 1470 & 7.3 & 15.0 & - & 1.9 \\ \text { August } & & & & & & & \\ 06 & 1055 & 0.0 & 1250 & 8.0 & 28.0 & 63.0 & 8.4 \\ 06 & 1056 & 2.00 & 1240 & 8.0 & 28.0 & - & 8.5 \\ 06 & 1057 & 4.00 & 1240 & 8.0 & 28.0 & -- & 8.5 \\ 06 & 1058 & 6.00 & 1240 & 8.0 & 27.5 & -- & 8.4 \\ 06 & 1059 & 8.00 & 1300 & 7.3 & 25.5 & -- & 4.6 \\ 06 & 1100 & 10.0 & 1350 & 7.1 & 23.5 & - & 1.1\end{array}$


Table 10. Vertical profiles of selected sites on study ponds-Continued

\begin{tabular}{|c|c|c|c|c|c|c|c|}
\hline $\begin{array}{l}\text { Sampling } \\
\text { date }\end{array}$ & Time & $\begin{array}{l}\text { Depth } \\
\text { (ft) }\end{array}$ & $\begin{array}{c}\text { Specific } \\
\text { conduct- } \\
\text { ance } \\
(\mu \mathrm{S} / \mathrm{cm})\end{array}$ & $\begin{array}{c}\text { pH } \\
\text { Water whole } \\
\text { fleld } \\
\text { (standard } \\
\text { unlts) }\end{array}$ & $\begin{array}{l}\text { Temper- } \\
\text { ature water } \\
\text { ('C) }\end{array}$ & $\begin{array}{c}\text { Transpar- } \\
\text { ency } \\
\text { (Secchl disk) } \\
\text { (in.) }\end{array}$ & $\begin{array}{l}\text { Oxygen, } \\
\text { dissolved } \\
\text { (mg/L) }\end{array}$ \\
\hline 06 & 1101 & 12.0 & 1340 & 7.1 & 22.0 & - & 0.6 \\
\hline 06 & 1102 & 14.0 & 1440 & 7.1 & 21.5 & - & 0.6 \\
\hline 06 & 1105 & 2.00 & 1240 & 8.0 & 28.0 & 63.0 & 8.5 \\
\hline 06 & 1106 & 2.00 & 1240 & 8.0 & 28.0 & 63.0 & 8.5 \\
\hline 06 & 1215 & -- & - & -- & -- & -- & -- \\
\hline 06 & 1245 & 3.00 & 1220 & -. & 28.0 & 63.0 & 8.7 \\
\hline 06 & 1246 & 3.00 & 1220 & -- & 28.0 & 63.0 & 8.7 \\
\hline
\end{tabular}

\section{Iron Post Coal Pond 6, Site 10 364051095274001}

May 1985

$\begin{array}{lccc}08 & 1100 & 0.0 & 1560 \\ 08 & 1101 & 2.00 & 1570 \\ 08 & 1102 & 4.00 & 1580 \\ 08 & 1103 & 6.00 & 1580 \\ 08 & 1104 & 8.00 & 1790 \\ 08 & 1105 & 10.0 & 2000 \\ 08 & 1106 & 12.0 & 2320 \\ 08 & 1107 & 14.0 & 2400 \\ 08 & 1108 & 16.0 & 2480 \\ 08 & 1109 & 18.0 & 2690 \\ 08 & 1110 & 20.0 & 2740 \\ 08 & 1111 & 21.0 & 2780 \\ 08 & 1115 & 2.00 & 1570 \\ 08 & 1120 & 20.0 & 2740\end{array}$

\section{4}

8.4

8.4

8.3

7.8

7.6

7.4

7.3

7.2

7.2

7.2

$-$

8.4

7.2

21.5
21.5
21.0
20.5
20.0
19.0
18.0
17.0
17.0
16.0
15.0
14.0
21.5
15.0

96.0

9.2

-- 9.2

$\begin{array}{ll}- & 9.0\end{array}$

$\begin{array}{ll}-- & 8.8\end{array}$

$\begin{array}{ll}- & 8.8\end{array}$

August

28

1130

Iron Post Coal Pond 6, Site 5 364052095274001

August 1985

$\begin{array}{lccc}20 & 1250 & 0.0 & 2770 \\ 20 & 1251 & 2.00 & 2770 \\ 20 & 1252 & 4.00 & 2770 \\ 20 & 1253 & 6.00 & 2770 \\ 20 & 1254 & 8.00 & 2770 \\ 20 & 1255 & 10.0 & 2910 \\ 20 & 1256 & 12.0 & 3420 \\ 20 & 1257 & 13.0 & 3450 \\ 20 & 1310 & 12.0 & 3420\end{array}$

7.6
7.6
7.6
7.6
7.6
7.5
6.8
--
6.8

26.5

126

7.4

26.5

7.4

26.5

7.4

26.5

7.4

26.5

7.4

26.0

6.4

21.0

0.7

$--$

19.5

0.3

21.0

126

0.7 
Table 10. Vertical profiles of selected sites on study ponds-Continued

\begin{tabular}{cccccccc}
\hline $\begin{array}{c}\text { Sampling } \\
\text { date }\end{array}$ & Time & $\begin{array}{c}\text { Depth } \\
(\mathrm{ft})\end{array}$ & $\begin{array}{c}\text { Specific } \\
\text { conduct- } \\
\text { ance } \\
(\mu \mathrm{S} / \mathrm{cm})\end{array}$ & $\begin{array}{c}\text { Water whole } \\
\text { fleld } \\
\text { (standard } \\
\text { unlts) }\end{array}$ & $\begin{array}{c}\text { Temper- } \\
\text { ature water } \\
\left({ }^{\circ} \mathrm{C}\right)\end{array}$ & $\begin{array}{c}\text { Transpar- } \\
\text { ency } \\
\text { (Secchi disk) } \\
\text { (in.) }\end{array}$ & $\begin{array}{c}\text { Oxygen, } \\
\text { dissolved } \\
\text { (mg/L) }\end{array}$ \\
\hline 20 & 1311 & 12.0 & 3420 & 6.8 & 21.0 & 126 & 0.7 \\
20 & 1315 & 6.00 & 2770 & 7.6 & 26.5 & 126 & 7.4 \\
20 & 1316 & 6.00 & 2770 & 7.6 & 26.5 & 126 & 7.4 \\
20 & 1317 & 6.00 & 2770 & 7.6 & 26.5 & - & 7.4
\end{tabular}

\section{Iron Post Coal Pond 7, Site 1 \\ 363825095284601}

May 1985

$\begin{array}{cccccccc}15 & 1315 & 0.50 & 1420 & 7.6 & 23.0 & 22.0 & 7.2 \\ 15 & 1315 & 0.50 & 1420 & 7.6 & 23.0 & 22.0 & 7.2 \\ 15 & 1316 & 2.00 & 1440 & 7.6 & 21.0 & - & 7.0 \\ 15 & 1316 & 2.00 & 1440 & 7.6 & 21.0 & -- & 7.0 \\ 15 & 1317 & 4.00 & 1440 & 7.5 & 20.0 & -- & 5.4 \\ 15 & 1317 & 4.00 & 1440 & 7.5 & 20.0 & -- & 5.4 \\ 15 & 1318 & 6.00 & 1400 & 7.5 & 19.0 & -- & 4.6 \\ 15 & 1318 & 6.00 & 1400 & 7.5 & 19.0 & -- & 4.6 \\ 15 & 1319 & 8.00 & 1850 & 7.2 & 19.5 & -- & 1.8 \\ 15 & 1319 & 8.00 & 1850 & 7.2 & 19.5 & -- & 1.8 \\ 15 & 1320 & 9.00 & 1930 & 7.2 & 19.0 & - & 1.7 \\ 15 & 1320 & 9.00 & 1930 & 7.2 & 19.0 & -- & 1.7 \\ 15 & 1330 & 4.00 & 1440 & 7.5 & 20.0 & 22.0 & 5.4 \\ 15 & 1330 & 4.00 & 1440 & 7.5 & 20.0 & 22.0 & 5.4 \\ \text { August } & & & & & & & \\ 20 & 1120 & 0.50 & 1720 & 7.6 & 26.0 & 36.0 & 11.2 \\ 20 & 1120 & 0.50 & 1720 & 7.6 & 26.0 & 36.0 & 11.2 \\ 20 & 1122 & 2.00 & 1720 & 7.6 & 26.5 & - & 10.8 \\ 20 & 1122 & 2.00 & 1720 & 7.6 & 26.5 & - & 10.8 \\ 20 & 1124 & 3.00 & 1710 & 7.6 & 26.5 & -- & 10.8 \\ 20 & 1124 & 3.00 & 1710 & 7.6 & 26.5 & -- & 10.8 \\ 20 & 1126 & 4.00 & 1710 & 7.6 & 26.5 & -- & 10.6 \\ 20 & 1126 & 4.00 & 1710 & 7.6 & 26.5 & -- & 10.6 \\ 20 & 1128 & 5.00 & 1710 & 7.5 & 26.0 & - & 10.4 \\ 20 & 1128 & 5.00 & 1710 & 7.5 & 26.0 & -- & 10.4 \\ 20 & 1130 & 6.00 & 1710 & 7.5 & 26.0 & - & 10.2 \\ 20 & 1130 & 6.00 & 1710 & 7.5 & 26.0 & -- & 10.2 \\ 20 & 1132 & 7.00 & 1710 & 7.5 & 26.0 & - & 9.2 \\ 20 & 1132 & 7.00 & 1710 & 7.5 & 26.0 & -- & 9.2 \\ 20 & 1134 & 8.00 & 1710 & 7.5 & 26.0 & -- & 7.2 \\ 20 & 1134 & 8.00 & 1710 & 7.5 & 26.0 & - & 7.2 \\ 20 & 1136 & 9.00 & 1740 & 7.4 & 25.5 & -- & 0.8\end{array}$


Table 10. Vertical profiles of selected sites on study ponds-Continued

\begin{tabular}{|c|c|c|c|c|c|c|c|}
\hline $\begin{array}{l}\text { Sampling } \\
\text { date }\end{array}$ & TIme & $\begin{array}{l}\text { Depth } \\
\text { (ft) }\end{array}$ & $\begin{array}{c}\text { Specific } \\
\text { conduct- } \\
\text { ance } \\
(\mu \mathrm{S} / \mathrm{cm})\end{array}$ & $\begin{array}{c}\text { pH } \\
\text { Water whole } \\
\text { fleld } \\
\text { (standard } \\
\text { units) }\end{array}$ & $\begin{array}{l}\text { Temper- } \\
\text { ature water } \\
\left({ }^{\circ} \mathrm{C}\right)\end{array}$ & $\begin{array}{c}\text { Transpar- } \\
\text { ency } \\
\text { (Secchi disk) } \\
\text { (In.) }\end{array}$ & $\begin{array}{c}\text { Oxygen, } \\
\text { dissolved } \\
\text { (mg/L) }\end{array}$ \\
\hline 20 & 1136 & 9.00 & 1740 & 7.4 & 25.5 & - & 0.8 \\
\hline 20 & 1255 & 2.00 & 1720 & 7.6 & 26.5 & 36.0 & 10.8 \\
\hline 20 & 1255 & 2.00 & 1720 & 7.6 & 26.5 & 36.0 & 10.8 \\
\hline 20 & 1256 & 2.00 & 1720 & 7.6 & 26.5 & 36.0 & 10.8 \\
\hline 20 & 1256 & 2.00 & 1720 & 7.6 & 26.5 & 36.0 & 10.8 \\
\hline
\end{tabular}

\section{Iron Post Coal Pond 8, Site 3} 364329095221601

May 1985

$\begin{array}{ll}09 & 1510 \\ 09 & 151 \\ 09 & 1512 \\ 09 & 1513 \\ 09 & 1514 \\ 09 & 1520\end{array}$

1510

1511

1512

1513

1514

1520

August

$\begin{array}{ll}19 & 1300 \\ 19 & 1302 \\ 19 & 1304 \\ 19 & 1305 \\ 19 & 1306 \\ 19 & 1307 \\ 19 & 1310 \\ 19 & 1315 \\ 19 & 1316 \\ 19 & 1317\end{array}$

$\begin{array}{ll}0.0 & 2000 \\ 2.00 & 2800 \\ 4.00 & 2920 \\ 6.00 & 2980 \\ 8.00 & 2990 \\ 4.00 & 2920\end{array}$

0.0

2.00

3660

3710

4.00

3730

$6.00 \quad 3890$

$8.00 \quad 4000$

$10.0 \quad 4070$

$--$

$2.00 \quad 3710$

2.00

2.00
7.1

7.0

7.0

7.0

7.0

7.0

8.1

7.8

7.4

6.8

6.5

6.3

--

7.8

7.8

7.8
16.5

17.0

16.5

16.5

16.5

16.5

22.5

21.5

18.0

17.5

17.0

16.0

21.5

21.5

21.5
$>96.0$

6.4

--

$-$

--

--

$>96.0$

72.0

--

$-$

$-$

--

$-$

$$
720
$$

72.0

72.0

72.0
10.6

13.2

12.4

11.1

13.2

\section{McAlester Coal Pond 1, Site 1}

\section{1}

July 1985

$\begin{array}{llll}18 & 1120 & - & -- \\ 18 & 1250 & 0.0 & 271 \\ 18 & 1252 & 5.00 & 270 \\ 18 & 1254 & 10.0 & 277 \\ 18 & 1255 & 15.0 & 336 \\ 18 & 1256 & 16.0 & 357 \\ 18 & 1257 & 20.0 & 405 \\ 18 & 1258 & 25.0 & 416 \\ 18 & 1259 & 30.0 & 439 \\ 18 & 1300 & 35.0 & 499\end{array}$

--
8.6
8.5
8.4
8.3
8.7
7.3
7.2
7.1
7.1

--
31.0
30.0
27.5
18.0
16.0
10.0
8.5
8.0
8.0

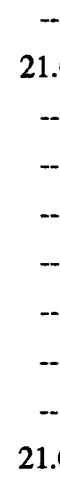

6.9

6.8

9.0

14.2

17.1

0.4

0.3

0.3

0.2 
Table 10. Vertical profiles of selected sites on study ponds-Continued

\begin{tabular}{|c|c|c|c|c|c|c|c|}
\hline $\begin{array}{l}\text { Sampling } \\
\text { date }\end{array}$ & Time & $\begin{array}{l}\text { Depth } \\
\text { (ft) }\end{array}$ & $\begin{array}{c}\text { Specifle } \\
\text { conduct- } \\
\text { ance } \\
(\mu S / \mathrm{cm})\end{array}$ & $\begin{array}{c}\text { pH } \\
\text { Water whole } \\
\text { fleld } \\
\text { (standard } \\
\text { unlts) }\end{array}$ & $\begin{array}{l}\text { Temper- } \\
\text { ature water } \\
\text { (ㄷ) }\end{array}$ & $\begin{array}{c}\text { Transpar- } \\
\text { ency } \\
\text { (Secchl disk) } \\
\text { (in.) }\end{array}$ & $\begin{array}{c}\text { Oxygen, } \\
\text { dissolved } \\
\text { (mg/L) }\end{array}$ \\
\hline 18 & 1301 & 38.0 & 596 & 7.0 & 8.0 & -- & 0.2 \\
\hline 18 & 1305 & 38.0 & 596 & 7.0 & 8.0 & 21.0 & 0.2 \\
\hline 18 & 1306 & 5.00 & 270 & 8.5 & 30.0 & 21.0 & 6.8 \\
\hline 18 & 1307 & 16.0 & 357 & 8.7 & 16.0 & -- & 17.1 \\
\hline 18 & 1310 & 5.00 & 270 & 8.5 & 30.0 & 21.0 & 6.8 \\
\hline 18 & 1311 & 38.0 & 596 & 7.0 & 8.0 & 21.0 & 0.2 \\
\hline
\end{tabular}

McAlester Coal Pond 1, Site 2

345906095043201

March 1985

14

14

14

14

14

14

14

14

14

14

14

14

14

14

14

14

July

18

18

18

18

18

18

18

18

18
1315

1317

1319

1320

1322

1323

1324

1325

1326

1327

1328

1329

1330

1331

1335

1340

1107

1109

1110

1111

1113

1114

1115

1330

1331
$0.0 \quad 256$

$3.00 \quad 258$

$6.00 \quad 258$

$9.00 \quad 252$

$11.0 \quad 282$

12.0

15.0

18.0

21.0

24.0

27.0

30.0

33.0

36.0

30.0

3.00

5.00

10.0

15.0

20.0

25.0

30.0

32.0

16.0

345
8.6

8.6

8.6

8.5

8.2

8.1

8.1

8.1

8.0

8.0

7.9

7.9

7.8

$--$

7.9

8.6

8.4

7.9

8.2

7.3

7.1

7.1

7.0

8.5
15.0

39.0

10.7

$\begin{array}{ll}- & 10.8\end{array}$

$\begin{array}{ll}- & 10.9\end{array}$

$\begin{array}{ll}- & 10.9\end{array}$

$\begin{array}{ll}- & 10.7\end{array}$

$\begin{array}{ll}- & 11.5\end{array}$

$\begin{array}{ll}-- & 10.2\end{array}$

$\begin{array}{ll}- & 10.0\end{array}$

$\begin{array}{ll}-- & 9.7\end{array}$

-
$-\quad 9.2$

$\begin{array}{ll}- & 8.7\end{array}$

$\begin{array}{ll}- & 7.5\end{array}$

-
$-\quad 5.2$

$\begin{array}{ll}- & 3.2\end{array}$

$39.0 \quad 7.5$

$\begin{array}{ll}39.0 & 10.8\end{array}$

$\begin{array}{lll}14.5 & 39.0 & 10.8\end{array}$

30.0

26.0

16.5

10.0

8.5

8.0

8.0

$\begin{array}{ll}-- & 6.1\end{array}$

$\begin{array}{ll}- & \\ - & 8.8\end{array}$

$\begin{array}{ll}- & 13.4\end{array}$

$\begin{array}{rr}- & 13.4 \\ -\quad 0.3\end{array}$

$\begin{array}{lll}-- & 0.2\end{array}$

$\begin{array}{lll}-- & 0.1\end{array}$

$\begin{array}{ll}- & 0.1 \\ - & 0.1\end{array}$

$24.0 \quad 12.5$ 
Table 10. Vertical profiles of selected sites on study ponds-Continued

\begin{tabular}{cccccccc}
\hline $\begin{array}{c}\text { Sampling } \\
\text { dato }\end{array}$ & Time & $\begin{array}{c}\text { Depth } \\
(\mathrm{ft})\end{array}$ & $\begin{array}{c}\text { Speciflc } \\
\text { conduct- } \\
\text { ance } \\
(\mu \mathrm{S} / \mathrm{cm})\end{array}$ & $\begin{array}{c}\text { Water whole } \\
\text { fleld } \\
\text { (otandard } \\
\text { unlts) }\end{array}$ & $\begin{array}{c}\text { Temper- } \\
\text { ature water } \\
\left({ }^{\circ} \mathrm{C}\right)\end{array}$ & $\begin{array}{c}\text { Transpar- } \\
\text { ency } \\
(\text { Secchl disk) } \\
(\text { in.) }\end{array}$ & $\begin{array}{c}\text { Oxygen, } \\
\text { dissolved } \\
(\mathbf{m g} / \mathrm{L})\end{array}$ \\
\hline
\end{tabular}

McAlester Coal Pond 2, Site 3 350926095091001

March 1985

$\begin{array}{cccccccc}19 & 1150 & 0.0 & 117 & 7.8 & 15.0 & 18.0 & 10.0 \\ 19 & 1151 & 4.00 & 116 & 7.8 & 14.5 & - & 10.0 \\ 19 & 1152 & 8.00 & 116 & 7.8 & 14.0 & - & 9.8 \\ 19 & 1153 & 12.0 & 119 & 7.8 & 12.5 & - & 8.2 \\ 19 & 1154 & 16.0 & 133 & 7.8 & 9.0 & - & 8.2 \\ 19 & 1155 & 20.0 & 136 & 7.9 & 7.5 & - & 7.8 \\ 19 & 1156 & 24.0 & 144 & 7.9 & 7.0 & -- & 5.5 \\ \text { July } & & & & & & & \\ 30 & 1220 & 0.0 & 66 & 8.4 & 31.0 & -- & 7.2 \\ 30 & 1221 & 2.00 & 66 & 8.4 & 31.0 & -- & 7.2 \\ 30 & 1222 & 4.00 & 66 & 8.4 & 30.5 & -- & 7.2 \\ 30 & 1223 & 6.00 & 66 & 8.4 & 30.5 & - & 7.2 \\ 30 & 1224 & 8.00 & 72 & 7.9 & 28.0 & - & 4.4 \\ 30 & 1225 & 10.0 & 80 & 7.6 & 24.5 & - & 2.1 \\ 30 & 1226 & 12.0 & 95 & 7.4 & 21.5 & - & 1.5 \\ 30 & 1227 & 14.0 & 117 & 7.3 & 17.0 & - & 1.3 \\ 30 & 1228 & 16.0 & 134 & 7.2 & 14.0 & -- & 0.6 \\ 30 & 1229 & 18.0 & 139 & 7.2 & 13.5 & -- & 0.5 \\ 30 & 1230 & 4.00 & 66 & 8.4 & 30.5 & - & 7.2\end{array}$

McAlester Coal Pond 2, Site 10 350930095085901

March 1985

$\begin{array}{rrrrrrrr}19 & 1220 & 0.0 & 117 & 8.0 & 15.0 & 18.0 & 10.2 \\ 19 & 1221 & 4.00 & 117 & 7.9 & 15.0 & -- & 10.2 \\ 19 & 1222 & 8.00 & 117 & 7.9 & 14.5 & -- & 10.0 \\ 19 & 1223 & 12.0 & 119 & 7.8 & 12.5 & -- & 8.4 \\ 19 & 1224 & 14.0 & 126 & 7.8 & 10.0 & -- & 8.2 \\ 19 & 1225 & 16.0 & 136 & 7.8 & 8.0 & -- & 8.0 \\ 19 & 1226 & 20.0 & 138 & 7.9 & 7.0 & -- & 7.0 \\ 19 & 1227 & 22.0 & 139 & -- & -- & -- & - \\ 19 & 1228 & 24.0 & 141 & 7.9 & 7.0 & -- & 6.2 \\ 19 & 1229 & 26.0 & 143 & 7.9 & 7.0 & -- & 5.8 \\ 19 & 1235 & 2.00 & 117 & 7.9 & 15.0 & 18.0 & 10.2 \\ 19 & 1240 & 26.0 & 143 & 7.9 & 7.0 & 18.0 & 5.8\end{array}$


Table 10. Vertical profiles of selected sites on study ponds-Continued

\begin{tabular}{|c|c|c|c|c|c|c|c|}
\hline $\begin{array}{l}\text { Sampling } \\
\text { date }\end{array}$ & Time & $\begin{array}{c}\text { Depth } \\
\text { (ft) }\end{array}$ & $\begin{array}{c}\text { Specific } \\
\text { conduct- } \\
\text { ance } \\
(\mu S / c m)\end{array}$ & $\begin{array}{c}\text { pH } \\
\text { Water whole } \\
\text { field } \\
\text { (standard } \\
\text { units) }\end{array}$ & $\begin{array}{l}\text { Temper- } \\
\text { ature water } \\
\left({ }^{\circ} \mathrm{C}\right)\end{array}$ & $\begin{array}{c}\text { Transpar- } \\
\text { ency } \\
\text { (Secchi disk) } \\
\text { (in.) }\end{array}$ & $\begin{array}{l}\text { Oxygen, } \\
\text { dissolved } \\
(\mathrm{mg} / \mathrm{L})\end{array}$ \\
\hline
\end{tabular}

McAlester Coal Pond 3, Site 3 351031095051501

April 1985

$\begin{array}{llllllll}24 & 1115 & 0.50 & 583 & 8.1 & 22.5 & 3.00 & 9.6 \\ 24 & 1117 & 5.00 & 577 & 7.7 & 19.5 & -- & 8.8 \\ 24 & 1118 & 10.0 & 578 & 7.6 & 19.0 & -- & 8.5 \\ 24 & 1120 & 15.0 & 586 & 7.5 & 15.5 & -- & 8.4 \\ 24 & 1122 & 20.0 & 601 & 7.3 & 15.0 & -- & 8.2 \\ 24 & 1124 & 25.0 & 617 & 7.3 & 14.0 & -- & 7.9 \\ 24 & 1126 & 30.0 & 630 & 7.3 & 13.0 & -- & 7.7 \\ 24 & 1128 & 35.0 & 637 & 7.2 & 13.0 & -- & 7.4 \\ 24 & 1140 & 40.0 & 639 & 7.1 & 12.5 & -- & 7.3\end{array}$

McAlester Coal Pond 3, Site 6 351038095051401

July 1985

$\begin{array}{rrrr}30 & 1315 & 0.50 & 710 \\ 30 & 1316 & 4.00 & 707 \\ 30 & 1317 & 10.0 & 698 \\ 30 & 1318 & 15.0 & 709 \\ 30 & 1319 & 20.0 & 735 \\ 30 & 1320 & 25.0 & 741 \\ 30 & 1321 & 30.0 & 745 \\ 30 & 1322 & 35.0 & 735 \\ 30 & 1323 & 40.0 & 744 \\ 30 & 1327 & -- & -\end{array}$

McAlester Coal Pond 4, Site 7 350708094502601

July 1985

$\begin{array}{llll}23 & 1320 & 0.0 & 509 \\ 23 & 1321 & 2.00 & 498 \\ 23 & 1322 & 4.00 & 497 \\ 23 & 1323 & 6.00 & 495 \\ 23 & 1324 & 8.00 & 495 \\ 23 & 1325 & 10.0 & 496 \\ 23 & 1326 & 12.0 & 503 \\ 23 & 1327 & 14.0 & 594 \\ 23 & 1328 & 16.0 & 679 \\ 23 & 1329 & 18.0 & 793 \\ 23 & 1335 & 6.00 & 495\end{array}$

$\begin{array}{llll}6.7 & 33.0 & -- & 6.5 \\ 6.7 & 33.0 & -- & 6.5 \\ 6.6 & 31.5 & -- & 6.3 \\ 6.6 & 30.5 & -- & 6.3 \\ 6.5 & 30.5 & -- & 6.2 \\ 6.5 & 30.5 & -- & 6.1 \\ 5.9 & 29.0 & -- & 3.1 \\ 5.8 & 24.0 & -- & 3.0 \\ 5.9 & 21.0 & -- & 2.2 \\ 6.2 & 18.0 & -- & 2.1 \\ 6.6 & 30.5 & -- & 6.3\end{array}$


Table 10. Vertical profiles of selected sites on study ponds-Continued

\begin{tabular}{|c|c|c|c|c|c|c|c|}
\hline $\begin{array}{l}\text { Sampling } \\
\text { date }\end{array}$ & Time & $\begin{array}{l}\text { Depth } \\
\text { (ft) }\end{array}$ & $\begin{array}{c}\text { Specific } \\
\text { conduct- } \\
\text { ance } \\
(\mu \mathrm{S} / \mathrm{cm})\end{array}$ & $\begin{array}{c}\text { pH } \\
\text { Water whole } \\
\text { flold } \\
\text { (standard } \\
\text { units) }\end{array}$ & $\begin{array}{l}\text { Temper- } \\
\text { ature water } \\
\left({ }^{\circ} \mathrm{C}\right)\end{array}$ & $\begin{array}{c}\text { Transpar- } \\
\text { oncy } \\
\text { (Secchi disk) } \\
\text { (in.) }\end{array}$ & $\begin{array}{l}\text { Oxygen, } \\
\text { dissolved } \\
\text { (mg/L) }\end{array}$ \\
\hline \multicolumn{8}{|c|}{$\begin{array}{c}\text { McAlester Coal Pond 4, Site } 9 \\
350708094503201\end{array}$} \\
\hline \multicolumn{8}{|l|}{ April 1985} \\
\hline 25 & 1045 & 0.0 & 491 & 6.5 & 22.0 & 42.0 & 9.0 \\
\hline 25 & 1046 & 2.00 & 495 & 6.5 & 22.0 & -- & 9.0 \\
\hline 25 & 1047 & 4.00 & 495 & 6.6 & 21.5 & -- & 9.0 \\
\hline 25 & 1048 & 6.00 & 493 & 6.6 & 21.0 & - & 8.9 \\
\hline 25 & 1049 & 8.00 & 493 & 6.6 & 21.0 & -- & 8.9 \\
\hline 25 & 1050 & 10.0 & 495 & 6.5 & 20.0 & -- & 8.8 \\
\hline 25 & 1051 & 12.0 & 503 & 6.3 & 18.0 & -- & 9.4 \\
\hline 25 & 1052 & 14.0 & 545 & 6.3 & 16.0 & -- & 9.5 \\
\hline 25 & 1053 & 16.0 & 611 & 6.0 & 14.0 & -- & 10.3 \\
\hline 25 & 1054 & 18.0 & 703 & 5.9 & 12.0 & -- & 9.5 \\
\hline 25 & 1055 & 20.0 & 739 & 5.9 & 12.5 & -- & 8.4 \\
\hline
\end{tabular}

McAlester Coal Pond 5 (86, M4), Slte 1 351637095065001

April 1985

$\begin{array}{lccc}25 & 1525 & 0.0 & 3100 \\ 25 & 1526 & 5.00 & 3200 \\ 25 & 1527 & 10.0 & 3200 \\ 25 & 1528 & 15.0 & 3300 \\ 25 & 1529 & 20.0 & 3400 \\ 25 & 1530 & 25.0 & 3500 \\ 25 & 1531 & 30.0 & 3600 \\ 25 & 1532 & 35.0 & 3700 \\ 25 & 1533 & 40.0 & 3800 \\ 25 & 1534 & 45.0 & 3900 \\ 25 & 1535 & 50.0 & 4100 \\ 25 & 1536 & 55.0 & 4200 \\ 25 & 1537 & 60.0 & 4300 \\ 25 & 1538 & 65.0 & 4400 \\ 25 & 1539 & 70.0 & 4450 \\ 25 & 1600 & 5.00 & 3200 \\ 25 & 1605 & 45.0 & 3900\end{array}$

$\begin{array}{rrrr}8.0 & 22.0 & 66.0 & 10.2 \\ 8.0 & 22.0 & - & 10.3 \\ 7.4 & 20.5 & -- & 8.9 \\ 7.3 & 19.0 & -- & 8.3 \\ 7.2 & 18.0 & -- & 6.4 \\ 7.1 & 17.5 & -- & 5.4 \\ 7.1 & 17.5 & -- & 5.0 \\ 7.1 & 17.0 & -- & 4.8 \\ 7.3 & 16.0 & -- & 5.8 \\ 7.3 & 13.0 & -- & 3.6 \\ 7.3 & 9.5 & -- & 4.9 \\ 7.5 & 8.5 & -- & 5.7 \\ 7.7 & 7.5 & -- & 6.0 \\ 7.5 & 7.5 & -- & 3.4 \\ 7.4 & 8.0 & -- & 3.0 \\ 8.0 & 22.0 & 66.0 & 10.3 \\ 7.3 & 13.0 & 66.0 & 3.6\end{array}$

McAlester Coal Pond 5 (86, M4), Slte 2

351639095064601

July 1985

24

1055

$0.0 \quad 3790$

8.6

30.5

84.0

8.1 
Table 10. Vertical profiles of selected sites on study ponds-Continued

\begin{tabular}{|c|c|c|c|c|c|c|c|}
\hline $\begin{array}{l}\text { Sampling } \\
\text { date }\end{array}$ & Time & $\begin{array}{l}\text { Depth } \\
\text { (ft) }\end{array}$ & $\begin{array}{c}\text { Specific } \\
\text { conduct- } \\
\text { ance } \\
(\mu \mathrm{S} / \mathrm{cm})\end{array}$ & $\begin{array}{c}\text { pH } \\
\text { Water whole } \\
\text { Ileld } \\
\text { (standard } \\
\text { unlts) }\end{array}$ & $\begin{array}{l}\text { Temper- } \\
\text { ature water } \\
\text { ('C) }\end{array}$ & $\begin{array}{c}\text { Transpar- } \\
\text { ency } \\
\text { (Secchi disk) } \\
\text { (In.) }\end{array}$ & $\begin{array}{c}\text { Oxygen, } \\
\text { dlssolved } \\
\text { (mg/L) }\end{array}$ \\
\hline 24 & 1056 & 5.00 & 3790 & 8.5 & 30.5 & -- & 8.0 \\
\hline 24 & 1057 & 10.0 & 3800 & 8.4 & 30.5 & -- & 7.9 \\
\hline 24 & 1058 & 15.0 & 3820 & 8.2 & 30.0 & - & 8.5 \\
\hline 24 & 1059 & 20.0 & 3950 & 7.1 & 24.0 & - & 8.3 \\
\hline 24 & 1100 & 25.0 & 4040 & 7.1 & 22.0 & -- & 4.4 \\
\hline 24 & 1101 & 30.0 & 4130 & 7.1 & 20.5 & -- & 1.8 \\
\hline 24 & 1102 & 35.0 & 4150 & 7.2 & 19.5 & -- & 0.4 \\
\hline 24 & 1103 & 40.0 & 4280 & 7.2 & 18.0 & - & 0.2 \\
\hline 24 & 1104 & 45.0 & 4630 & 7.3 & 16.0 & -- & 0.2 \\
\hline 24 & 1105 & 50.0 & 4660 & 7.4 & 14.5 & - & 0.2 \\
\hline 24 & 1106 & 55.0 & 4640 & 7.4 & 13.5 & -- & 0.2 \\
\hline 24 & 1107 & 60.0 & 4690 & 7.6 & 11.5 & -- & 0.2 \\
\hline 24 & 1108 & 65.0 & 4700 & 7.8 & 10.0 & - & 0.2 \\
\hline 24 & 1109 & 70.0 & 4660 & 7.8 & 9.5 & -- & 0.2 \\
\hline 24 & 1110 & 75.0 & 4930 & 7.8 & 9.5 & -- & 0.2 \\
\hline 24 & 1111 & 80.0 & 5330 & 7.6 & 10.0 & -- & 0.2 \\
\hline 24 & 1150 & 5.00 & 3790 & 8.5 & 30.5 & 84.0 & 8.0 \\
\hline 24 & 1151 & 80.0 & 5330 & 7.6 & 10.0 & 84.0 & 0.2 \\
\hline 24 & 1155 & 80.0 & 5330 & 7.6 & 10.0 & 84.0 & 0.2 \\
\hline 24 & 1156 & 5.00 & 3790 & 8.5 & 30.5 & 84.0 & 8.0 \\
\hline 24 & 1157 & 15.0 & 3820 & 8.2 & 30.0 & 84.0 & 8.5 \\
\hline
\end{tabular}

\section{McAlester Coal Pond 6, Site 7}

$\mathbf{3 5 1 7 4 3 0 9 5 0 5 4 3 0 1}$

April 1985

$\begin{array}{rrrrrrrr}24 & 1645 & 0.0 & 2230 & 8.4 & 24.0 & 84.0 & 8.6 \\ 24 & 1646 & 5.00 & 2220 & 8.4 & 21.0 & - & 9.1 \\ 24 & 1647 & 10.0 & 2260 & 8.3 & 19.5 & - & 8.9 \\ 24 & 1648 & 12.0 & -- & -- & -- & - & 10.0 \\ 24 & 1649 & 15.0 & 2610 & 7.9 & 14.0 & - & 10.8 \\ 24 & 1650 & 20.0 & 2750 & 7.7 & 11.0 & -- & 7.0 \\ 24 & 1651 & 25.0 & 3260 & 7.3 & 10.5 & - & 3.5 \\ 24 & 1652 & 29.0 & 3500 & 7.2 & 10.5 & - & 3.5 \\ \text { July } & & & & & & & \\ 25 & 1230 & 0.0 & 2060 & 8.0 & 30.0 & -- & 7.7 \\ 25 & 1231 & 2.00 & 2060 & 8.0 & 30.0 & -- & 7.7 \\ 25 & 1232 & 4.00 & 2070 & 8.0 & 30.0 & - & 7.8 \\ 25 & 1233 & 6.00 & 2070 & 8.0 & 29.5 & - & 7.8 \\ 25 & 1234 & 8.00 & 2070 & 7.9 & 29.5 & - & 7.7 \\ 25 & 1235 & 10.0 & 2140 & 7.3 & 28.0 & - & 9.0\end{array}$


Table 10. Vertical profiles of selected sites on study ponds - Continued

\begin{tabular}{|c|c|c|c|c|c|c|c|}
\hline $\begin{array}{l}\text { Sampling } \\
\text { date }\end{array}$ & Time & $\begin{array}{l}\text { Depth } \\
\text { (ft) }\end{array}$ & $\begin{array}{c}\text { Specific } \\
\text { conduct- } \\
\text { ance } \\
(\mu \mathrm{S} / \mathrm{cm})\end{array}$ & $\begin{array}{c}\text { pH } \\
\text { Water whole } \\
\text { fleld } \\
\text { (standard } \\
\text { units) }\end{array}$ & $\begin{array}{l}\text { Temper- } \\
\text { ature water } \\
\left({ }^{\circ} \mathrm{C}\right)\end{array}$ & $\begin{array}{l}\text { Transpar- } \\
\text { ency } \\
\text { (Secchi dlsk) } \\
\text { (in.) }\end{array}$ & $\begin{array}{l}\text { Oxygen, } \\
\text { dissolved } \\
\text { (mg/L) }\end{array}$ \\
\hline 25 & 1236 & 12.0 & 2240 & 7.3 & 25.0 & - & 8.4 \\
\hline 25 & 1237 & 14.0 & 2390 & 7.3 & 22.0 & -- & 10.1 \\
\hline 25 & 1238 & 16.0 & 2530 & 7.3 & 20.5 & -- & 14.7 \\
\hline 25 & 1239 & 18.0 & 2840 & 7.3 & 18.0 & - & 19.1 \\
\hline 25 & 1240 & 20.0 & 2960 & 7.2 & 17.0 & - & 13.1 \\
\hline 25 & 1241 & 22.0 & 3050 & 7.1 & 15.5 & -- & 0.7 \\
\hline 25 & 1242 & 24.0 & 3200 & 7.1 & 14.5 & -- & 0.3 \\
\hline 25 & 1243 & 26.0 & 3260 & 7.1 & 14.0 & -- & 0.3 \\
\hline 25 & 1244 & 28.0 & 3270 & 7.1 & 14.0 & -- & 0.3 \\
\hline 25 & 1250 & 18.0 & 2840 & 7.3 & 18.0 & -- & 19.1 \\
\hline
\end{tabular}

McAlester Coal Pond 7 (86,M6), Site 7

352001094583501

July 1985

$\begin{array}{rrrrrrrr}31 & 1055 & -- & - & -- & -- & - & - \\ 31 & 1100 & 0.0 & 322 & 8.1 & 31.0 & 36.0 & 11.2 \\ 31 & 1101 & 1.00 & 322 & 8.1 & 31.0 & -- & 10.8 \\ 31 & 1102 & 2.00 & 327 & 8.0 & 31.0 & -- & 10.8 \\ 31 & 1103 & 4.00 & 323 & 8.0 & 31.0 & -- & 10.7 \\ 31 & 1104 & 6.00 & 323 & 7.8 & 30.5 & -- & 9.8 \\ 31 & 1105 & 8.00 & 398 & 7.0 & 25.5 & -- & 5.9 \\ 31 & 1106 & 10.0 & 495 & 6.6 & 20.5 & - & 2.8 \\ 31 & 1115 & 2.00 & 327 & 8.0 & 31.0 & 36.0 & 10.8 \\ 31 & 1116 & 2.00 & 327 & 8.0 & 31.0 & 36.0 & 10.8 \\ 31 & 1230 & 2.00 & 327 & 8.0 & 31.0 & -- & 10.8\end{array}$

McAlester Coal Pond 7 (86,M6), Site 10 352001094583701

March 1985

$\begin{array}{llllllll}21 & 1420 & 0.0 & 238 & 7.4 & 12.5 & 12.0 & 9.7 \\ 21 & 1421 & 2.00 & 237 & 7.4 & 12.5 & - & 9.4 \\ 21 & 1422 & 4.00 & 237 & 7.4 & 12.5 & - & 9.4 \\ 21 & 1423 & 6.00 & 236 & 7.4 & 12.5 & - & 9.2 \\ 21 & 1424 & 8.00 & 237 & 7.2 & 12.5 & -- & 8.0 \\ 21 & 1425 & 10.0 & 262 & 7.0 & 11.0 & - & 4.4 \\ 21 & 1426 & 12.0 & 275 & 6.7 & 10.0 & - & 1.8 \\ 21 & 1430 & 4.00 & 237 & 7.4 & 12.5 & - & 9.4\end{array}$

July

31

1225 
Table 10. Vertical profiles of selected sites on study ponds-Continued

\begin{tabular}{|c|c|c|c|c|c|c|c|}
\hline $\begin{array}{l}\text { Sampling } \\
\text { date }\end{array}$ & Time & $\begin{array}{c}\text { Depth } \\
\text { (ft) }\end{array}$ & $\begin{array}{c}\text { Specific } \\
\text { conduct- } \\
\text { ance } \\
(\mu \mathrm{S} / \mathrm{cm})\end{array}$ & $\begin{array}{c}\text { pH } \\
\text { Water whole } \\
\text { fleid } \\
\text { (standard } \\
\text { units) }\end{array}$ & $\begin{array}{l}\text { Temper- } \\
\text { ature water } \\
\left({ }^{\circ} \mathrm{C}\right)\end{array}$ & $\begin{array}{c}\text { Transpar- } \\
\text { ency } \\
\text { (Secchi disk) } \\
\text { (In.) }\end{array}$ & $\begin{array}{l}\text { Oxygen, } \\
\text { dlssolved } \\
\text { (mg/L) }\end{array}$ \\
\hline
\end{tabular}

McAlester Coai Pond 8, Site 2 352239095143901

March 1985

\begin{tabular}{|c|c|c|c|c|}
\hline 07 & 1238 & 1.00 & 815 & 6.6 \\
\hline 07 & 1240 & 3.00 & 813 & 6.6 \\
\hline 07 & 1242 & 5.00 & 813 & 6.6 \\
\hline 07 & 1243 & 6.00 & 813 & 6.6 \\
\hline
\end{tabular}

July 1985

$\begin{array}{rccccccc}31 & 1000 & 0.50 & 1640 & 8.0 & 29.5 & - & 8.2 \\ 31 & 1001 & 3.00 & 1610 & 8.0 & 29.5 & - & 8.1 \\ 31 & 1002 & 6.00 & 1800 & 7.1 & 24.0 & -- & 3.0 \\ 31 & 1003 & 9.00 & 1960 & 7.1 & 19.5 & - & 0.5 \\ 31 & 1004 & 12.0 & 2270 & 7.1 & 17.5 & -- & 0.3 \\ 31 & 1006 & 15.0 & 2340 & 7.2 & 16.5 & -- & 0.3 \\ 31 & 1007 & 18.0 & 2360 & 7.2 & 16.0 & - & 0.2 \\ 31 & 1008 & 21.0 & 2360 & 7.3 & 15.5 & -- & 0.2 \\ 31 & 1009 & 24.0 & 2370 & 7.3 & 15.5 & -- & 0.2 \\ 31 & 1230 & 4.00 & 1610 & 7.8 & 30.0 & -- & 8.0\end{array}$

McAlester Coai Pond 9, Site 10 352506095134101

July 1985

\begin{tabular}{|c|c|c|c|c|c|c|c|}
\hline 22 & 1200 & -- & -- & -- & -- & -- & -- \\
\hline 22 & 1310 & 0.0 & 539 & 7.8 & 32.0 & 56.0 & 8.6 \\
\hline 22 & 1311 & 2.00 & 537 & 7.8 & 31.0 & - & 8.5 \\
\hline 22 & 1312 & 4.00 & 537 & 7.7 & 31.0 & -- & 8.4 \\
\hline 22 & 1313 & 6.00 & 537 & 7.7 & 30.5 & -- & 8.4 \\
\hline 22 & 1314 & 8.00 & 537 & 7.7 & 30.5 & -- & 6.9 \\
\hline 22 & 1315 & 10.0 & 579 & 6.9 & 28.5 & - & 2.3 \\
\hline 22 & 1316 & 12.0 & 720 & 6.7 & 24.0 & -- & 1.0 \\
\hline 22 & 1317 & 14.0 & 943 & 7.0 & 21.0 & -- & 1.1 \\
\hline 22 & 1318 & 16.0 & 1160 & 6.9 & 15.5 & -- & 1.2 \\
\hline 22 & 1319 & 18.0 & 1350 & 6.9 & 15.0 & -- & 1.2 \\
\hline 22 & 1330 & 6.00 & 537 & 7.7 & 30.5 & 56.0 & 8.4 \\
\hline 22 & 1331 & 6.00 & 537 & 7.7 & 30.5 & 56.0 & 8.4 \\
\hline 22 & 1332 & 6.00 & 537 & 7.7 & 30.5 & 56.0 & 8.4 \\
\hline 22 & 1335 & 18.0 & 1350 & 6.9 & 15.0 & 56.0 & 1.2 \\
\hline 22 & 1336 & 18.0 & 1350 & 6.9 & 15.0 & 56.0 & 1.2 \\
\hline
\end{tabular}


Table 10. Vertical profiles of selected sites on study ponds-Continued

\begin{tabular}{|c|c|c|c|c|c|c|c|}
\hline $\begin{array}{l}\text { Sampling } \\
\text { date }\end{array}$ & Time & $\begin{array}{l}\text { Depth } \\
\text { (ft) }\end{array}$ & $\begin{array}{c}\text { Specific } \\
\text { conduct- } \\
\text { ance } \\
(\mu \mathrm{S} / \mathrm{cm})\end{array}$ & $\begin{array}{c}\text { pH } \\
\text { Water whole } \\
\text { fleld } \\
\text { (standard } \\
\text { units) }\end{array}$ & $\begin{array}{l}\text { Temper- } \\
\text { ature water } \\
\left({ }^{\circ} \mathrm{C}\right)\end{array}$ & $\begin{array}{c}\text { Transpar- } \\
\text { ency } \\
\text { (Secchl dlsk) } \\
\text { (In.) }\end{array}$ & $\begin{array}{l}\text { Oxygen, } \\
\text { dissolved } \\
\text { (mg/L) }\end{array}$ \\
\hline \multicolumn{8}{|c|}{$\begin{array}{c}\text { McAlester Coal Pond 9, Site } 16 \\
352513095134301\end{array}$} \\
\hline \multicolumn{8}{|l|}{ March 1985} \\
\hline 18 & 1530 & 0.0 & 397 & 7.9 & 17.0 & 15.0 & 10.3 \\
\hline 18 & 1531 & 2.00 & 395 & 7.9 & 16.0 & - & 10.3 \\
\hline 18 & 1532 & 4.00 & 394 & 7.9 & 16.0 & -- & 10.5 \\
\hline 18 & 1533 & 6.00 & 394 & 7.9 & 15.0 & -- & 10.4 \\
\hline 18 & 1535 & 8.00 & 392 & 7.9 & 14.0 & - & 10.2 \\
\hline 18 & 1536 & 10.0 & 390 & 7.8 & 13.0 & -- & 9.8 \\
\hline 18 & 1537 & 12.0 & 404 & 7.5 & 11.5 & - & 8.1 \\
\hline 18 & 1538 & 14.0 & 415 & 7.4 & 10.5 & -- & 7.2 \\
\hline 18 & 1540 & 16.0 & 435 & 7.3 & 10.5 & -- & 6.8 \\
\hline 18 & 1542 & 18.0 & 466 & 7.2 & 10.0 & - & 6.1 \\
\hline
\end{tabular}




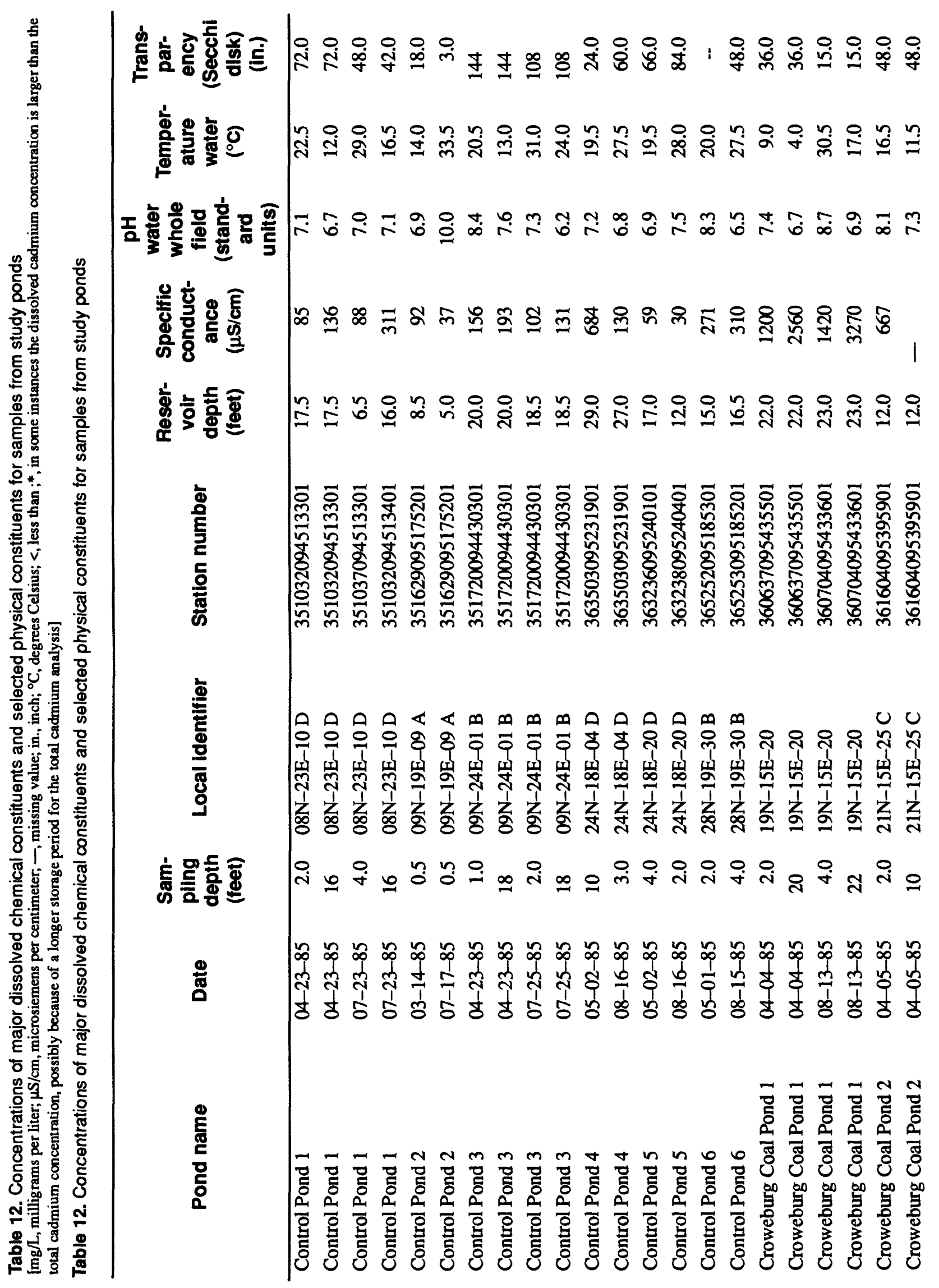




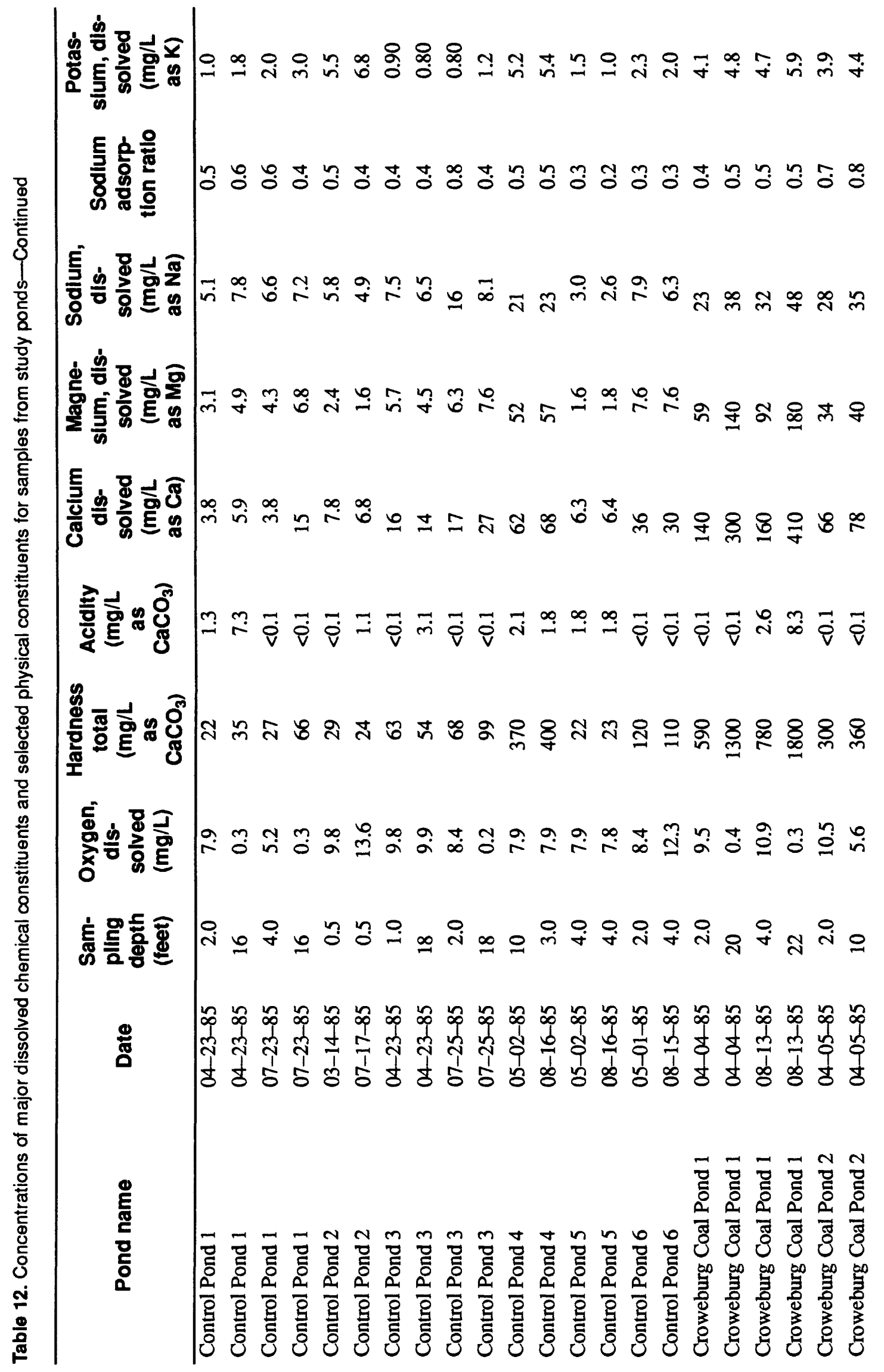


|

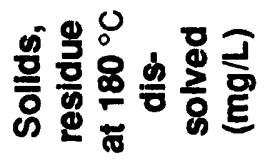
융ㅇㅇ

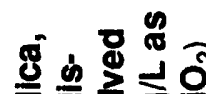

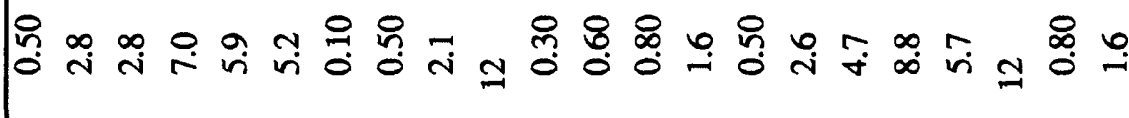
के 응

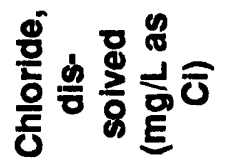

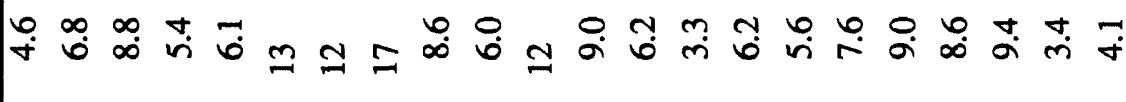

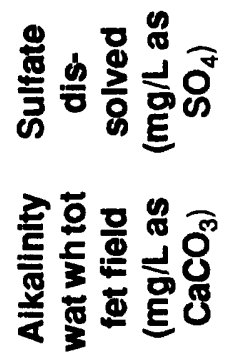

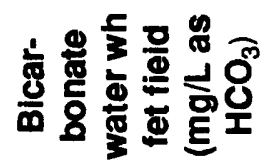

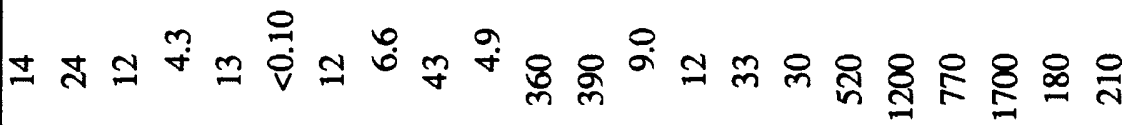
六 ह

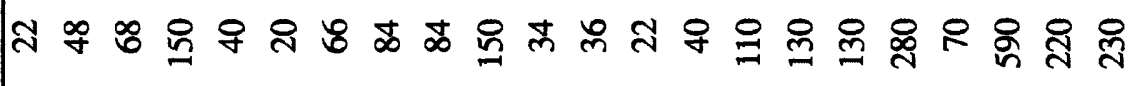
운

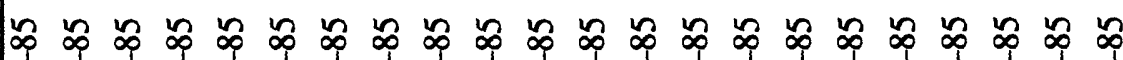
$\stackrel{\$}{0}$ సิ

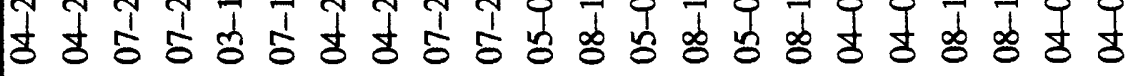

톨

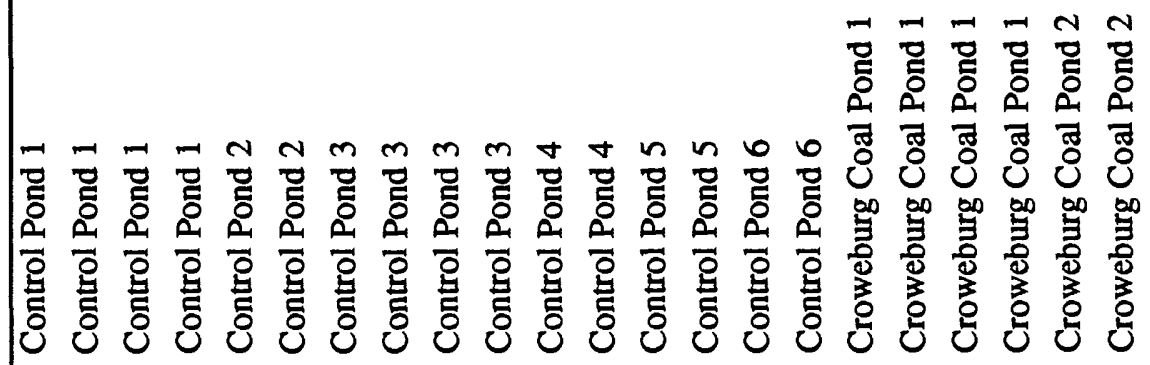




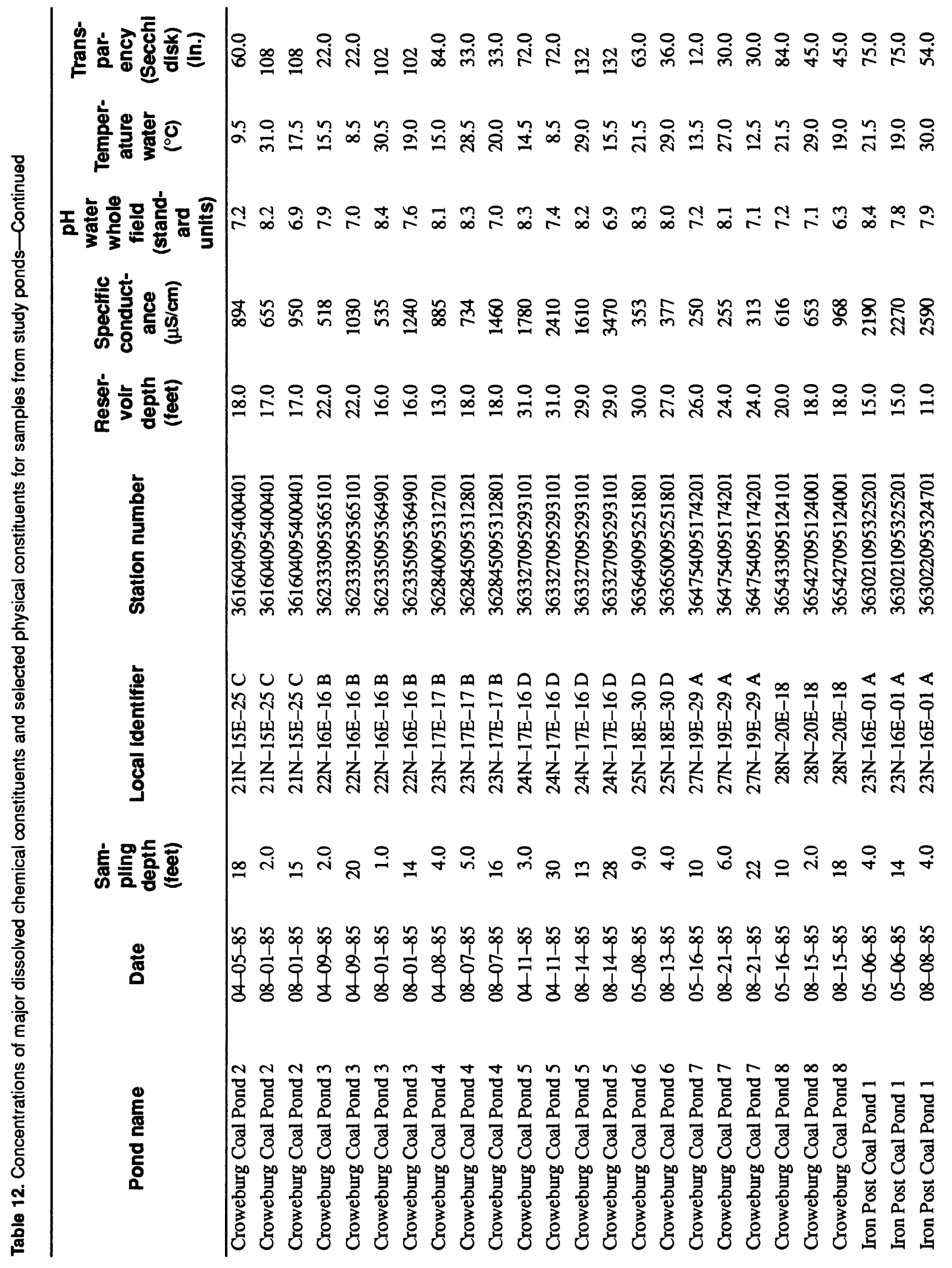




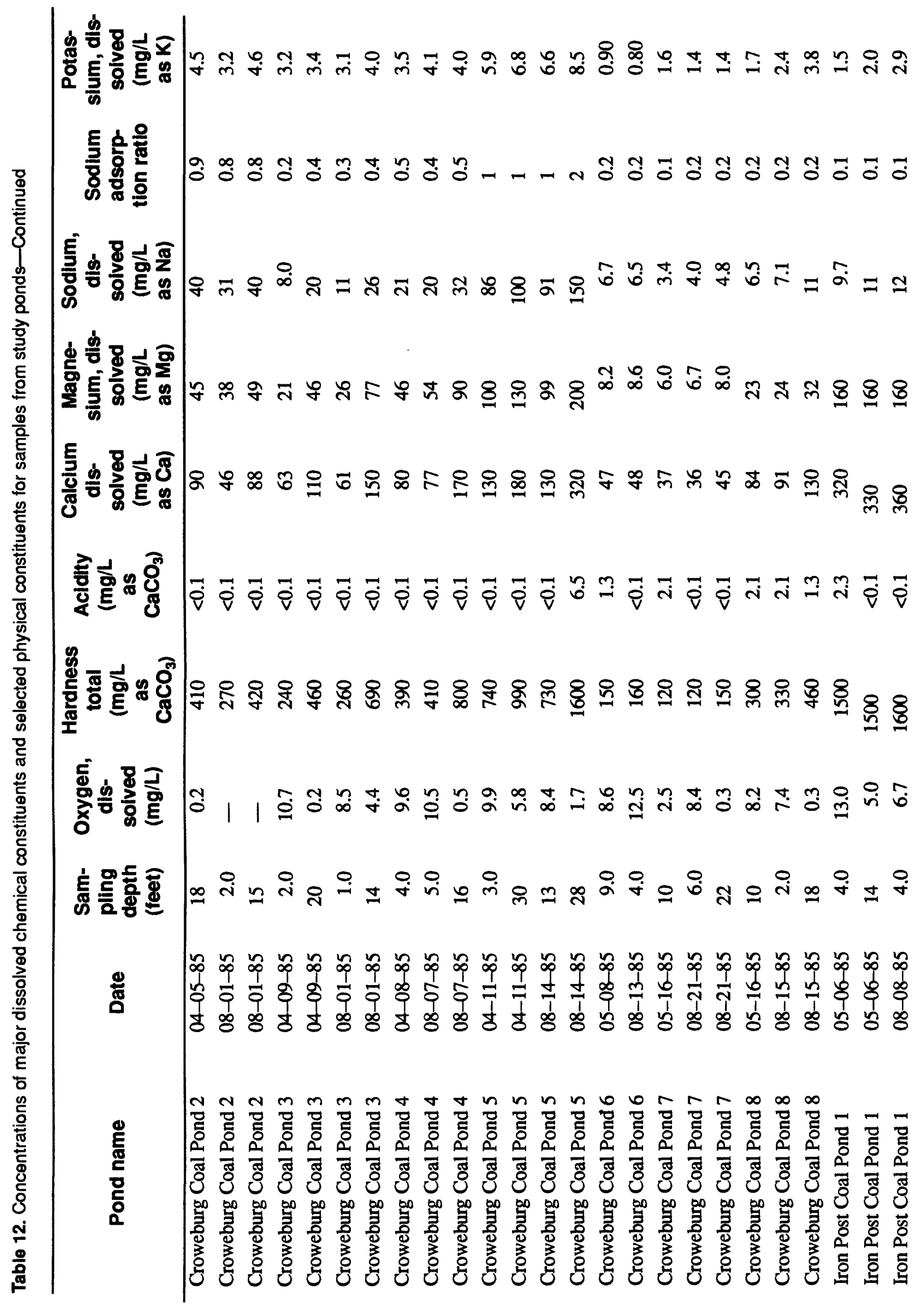




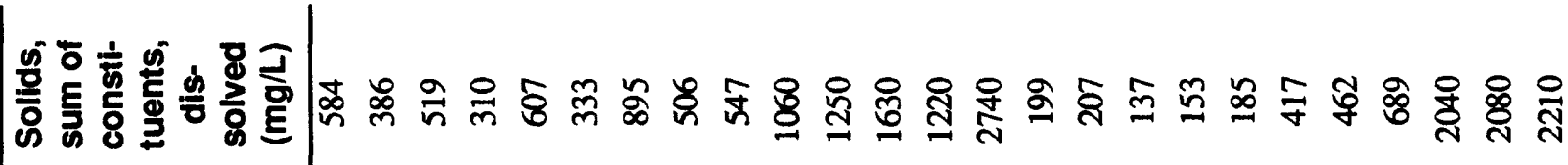

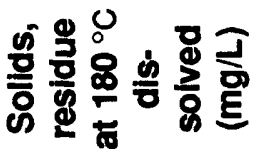

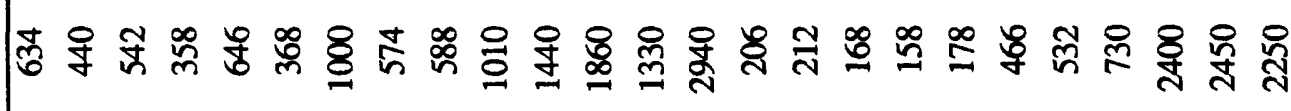

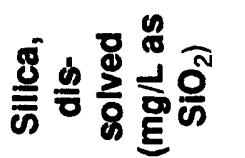

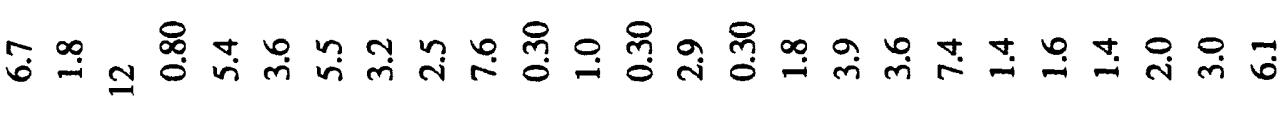

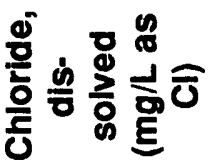

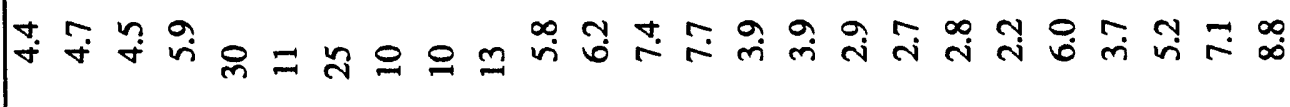

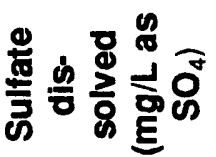

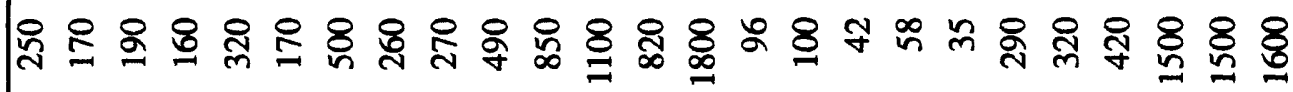
륻홍요 들

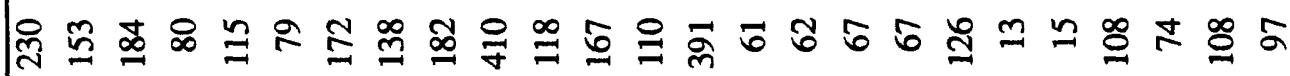

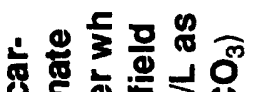

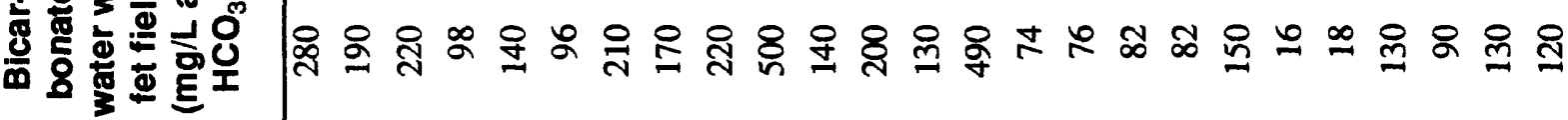

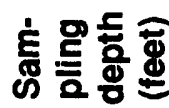

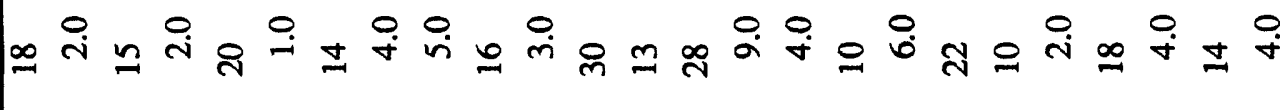

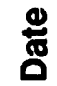

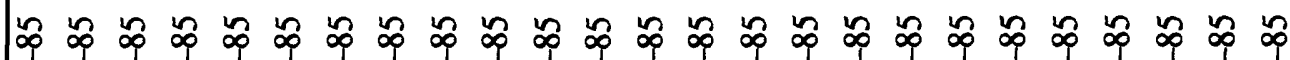

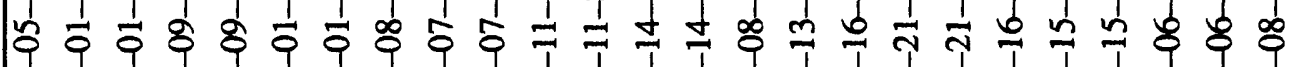

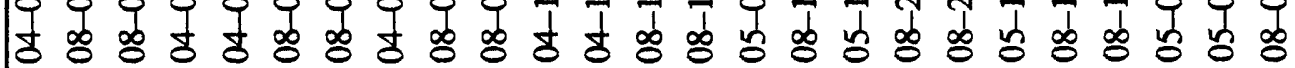

응
음
응

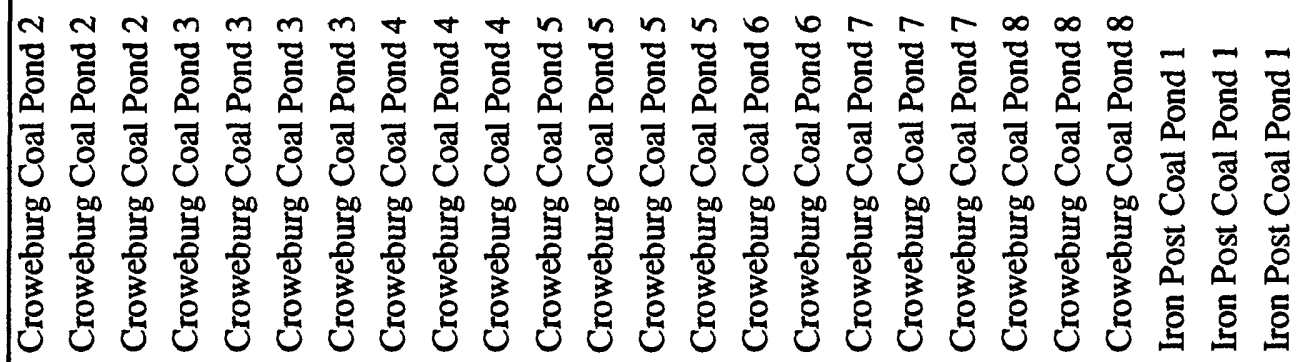




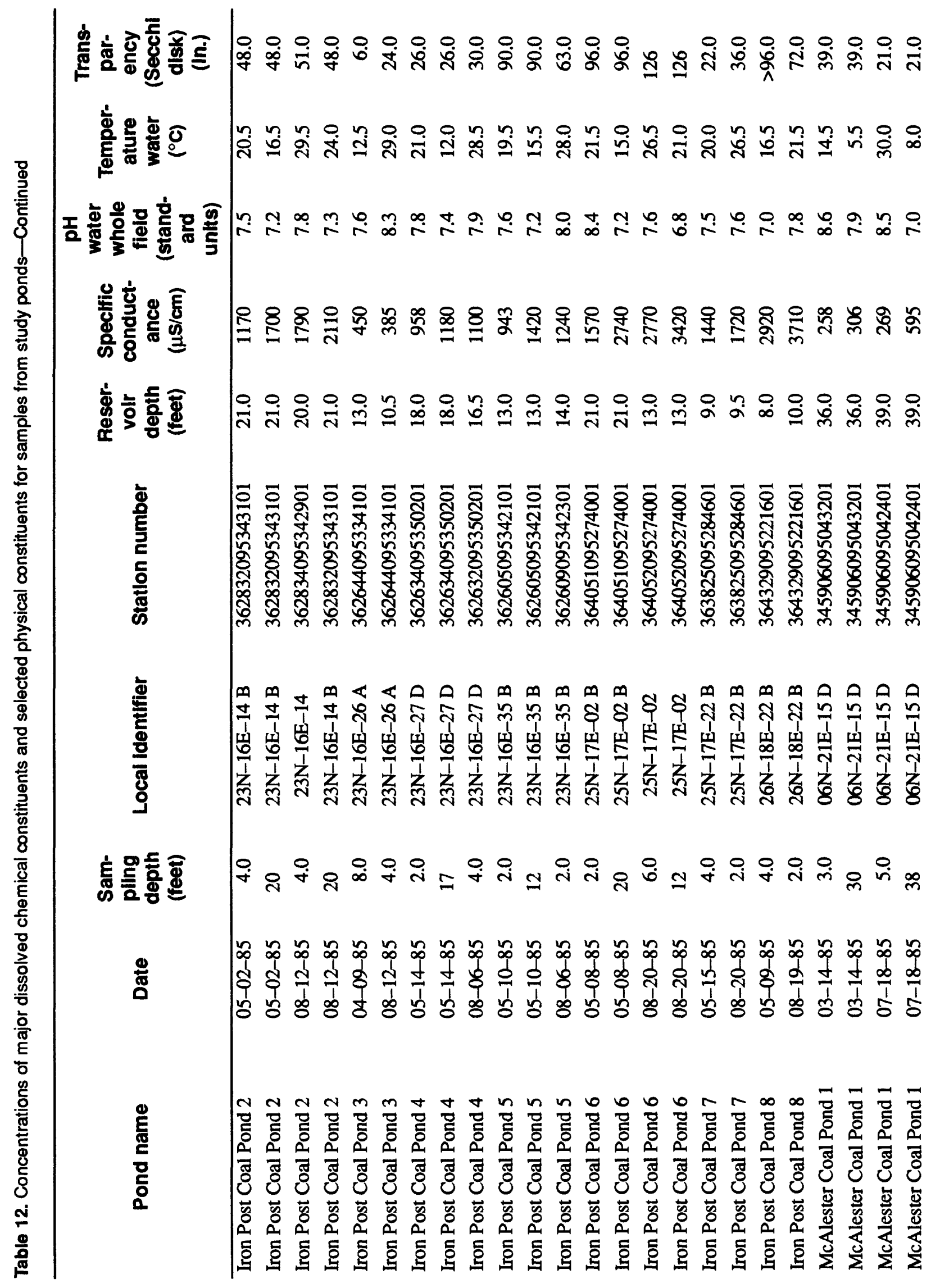




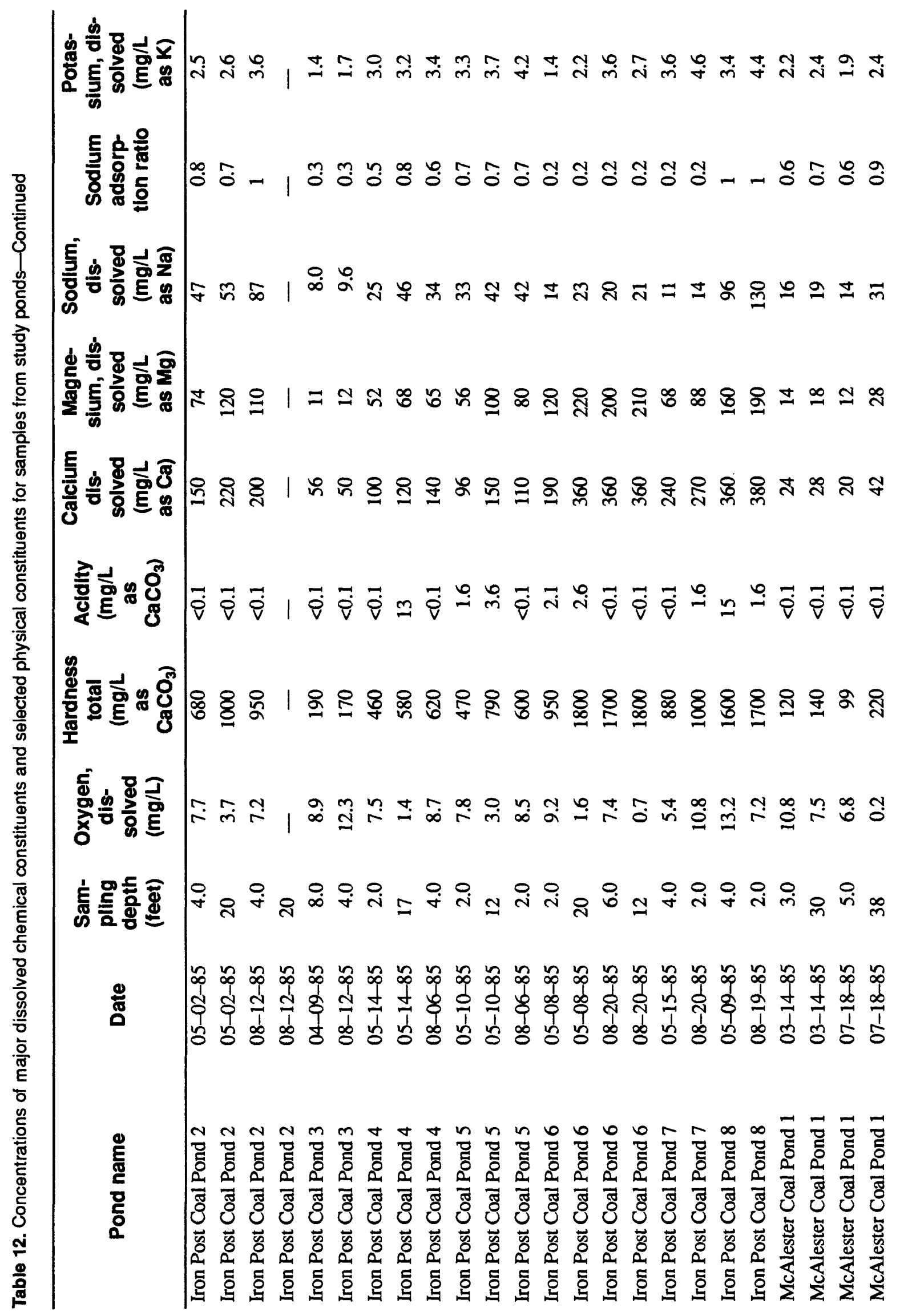


|

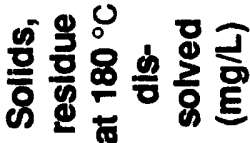

즐음

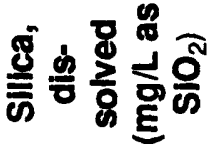

응 8

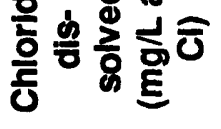

$=\simeq \Sigma 1$ 암

ڤँ

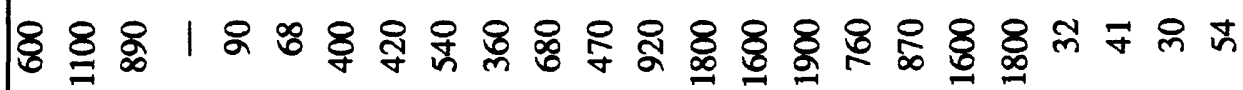

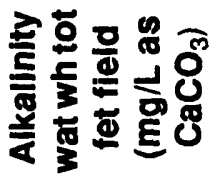

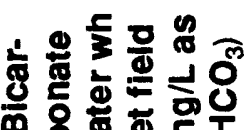

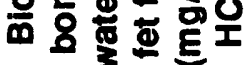

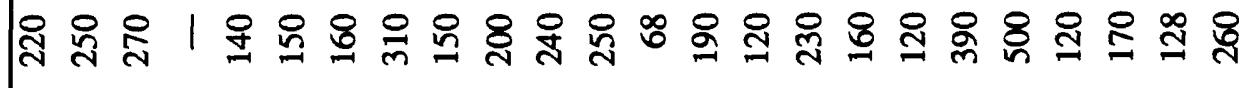
틀응형

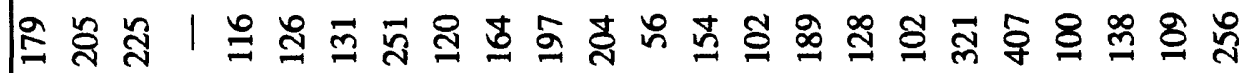
๓ั口ळ

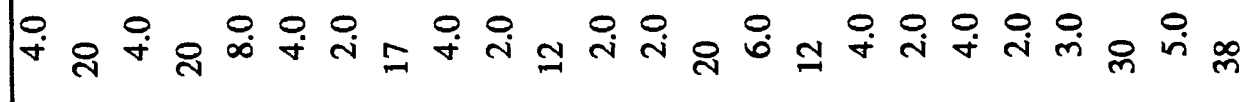

ธัตั

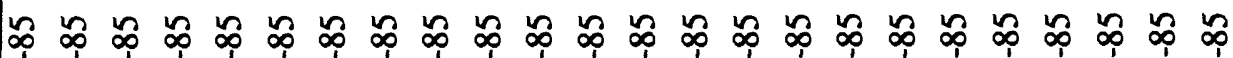

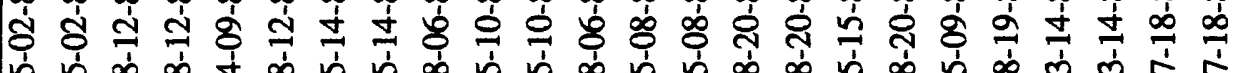

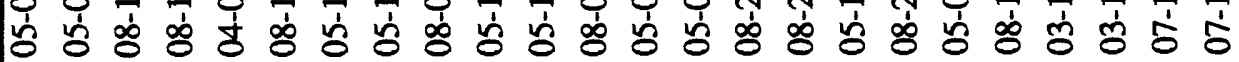




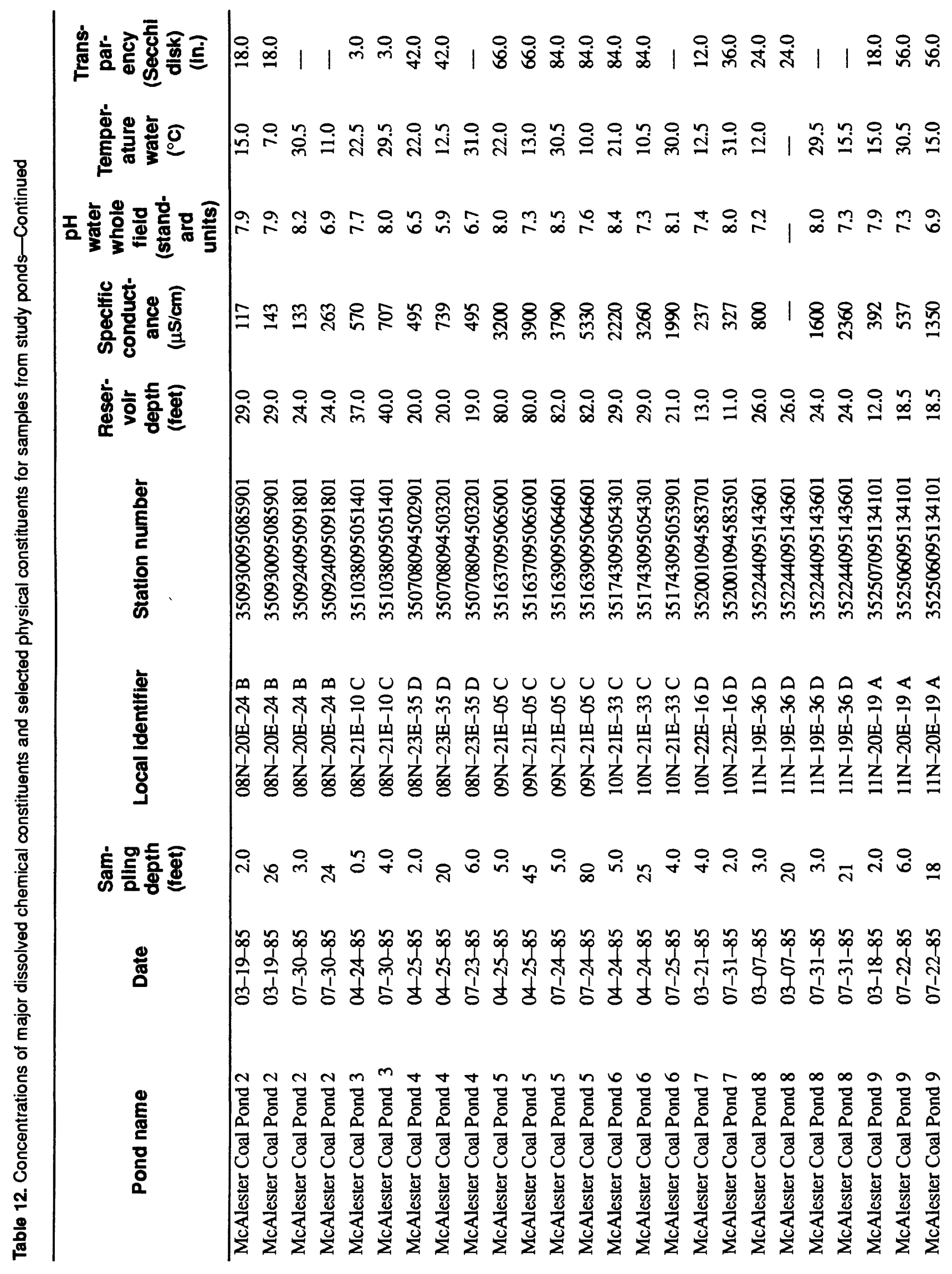




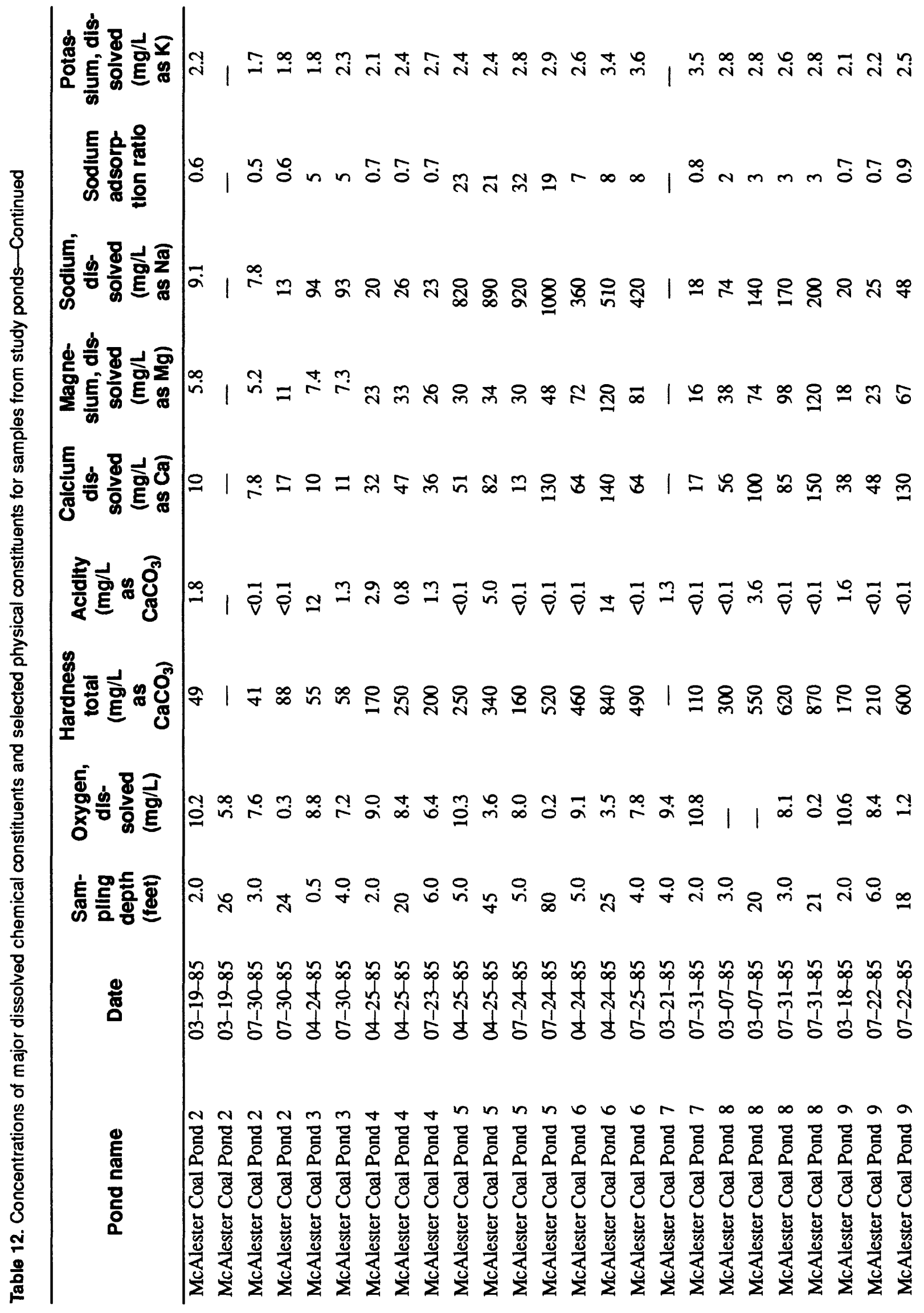




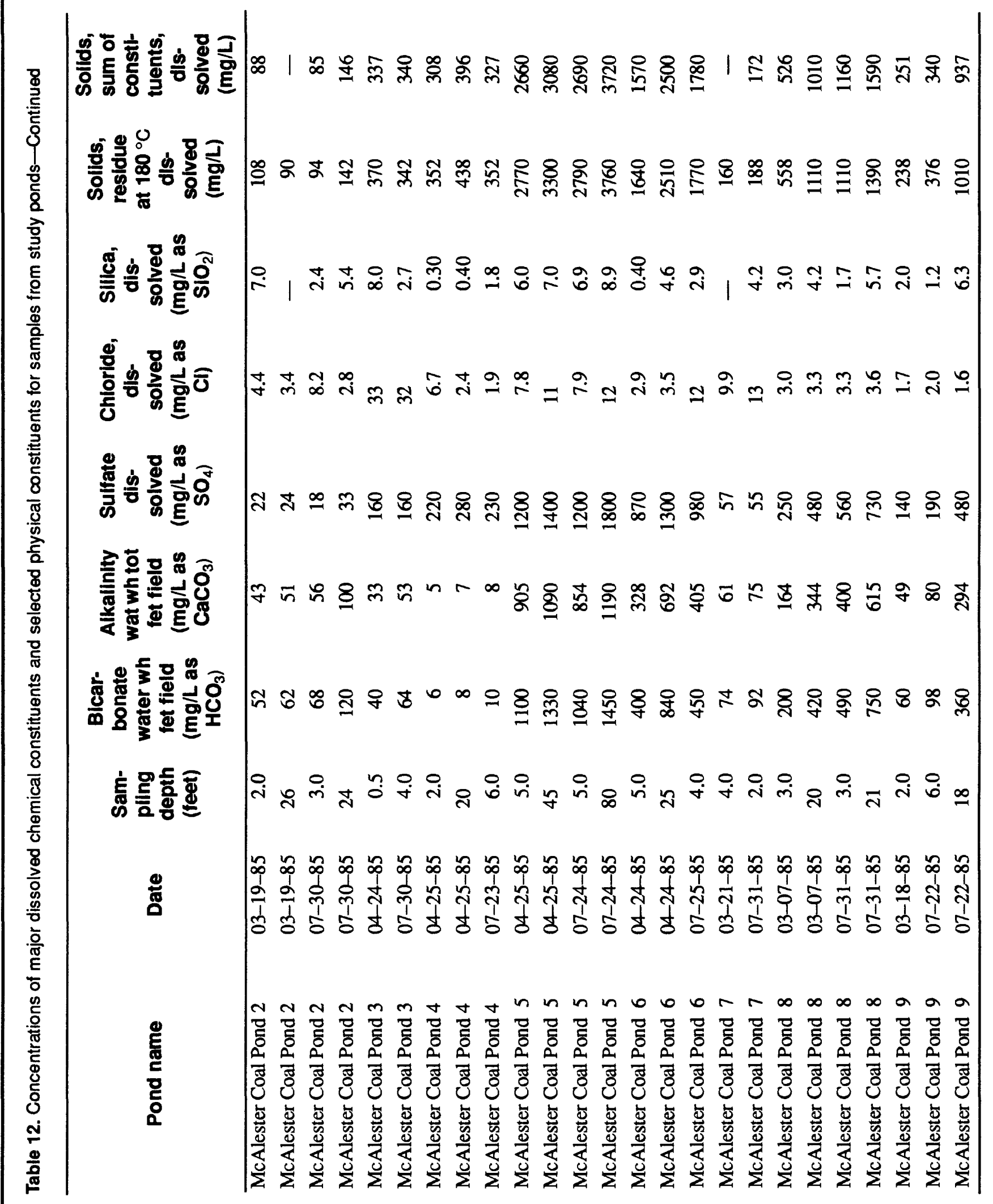




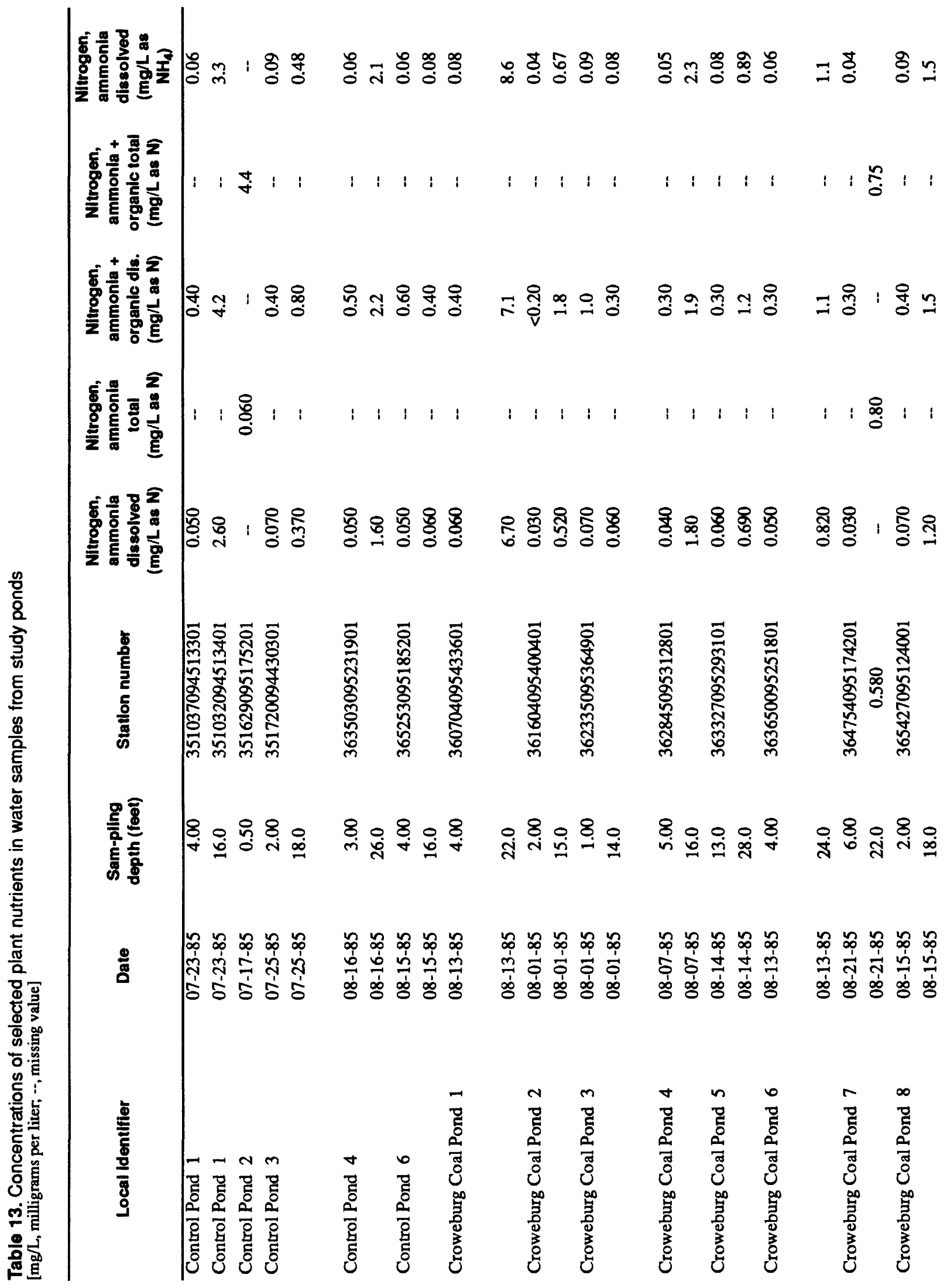




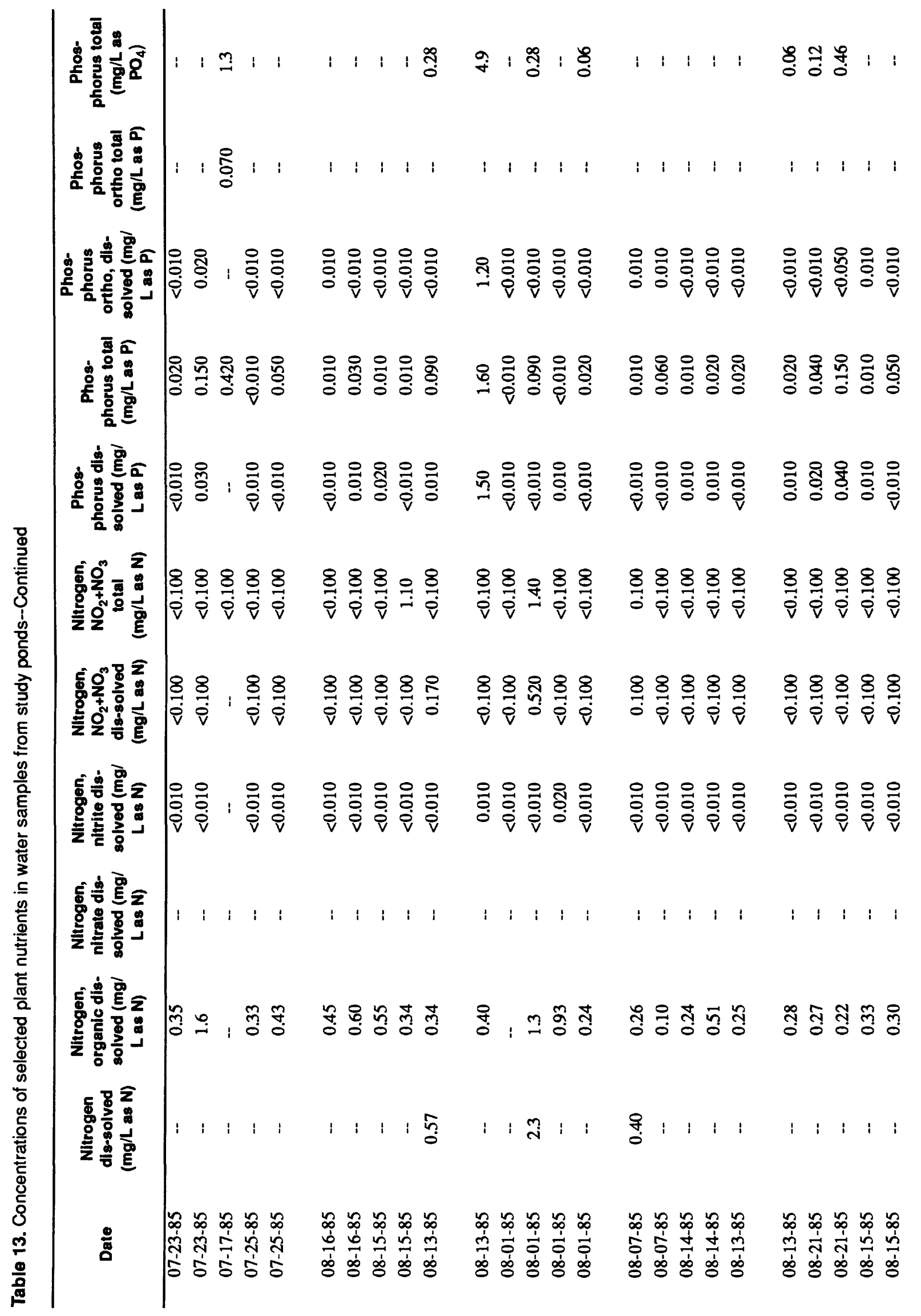




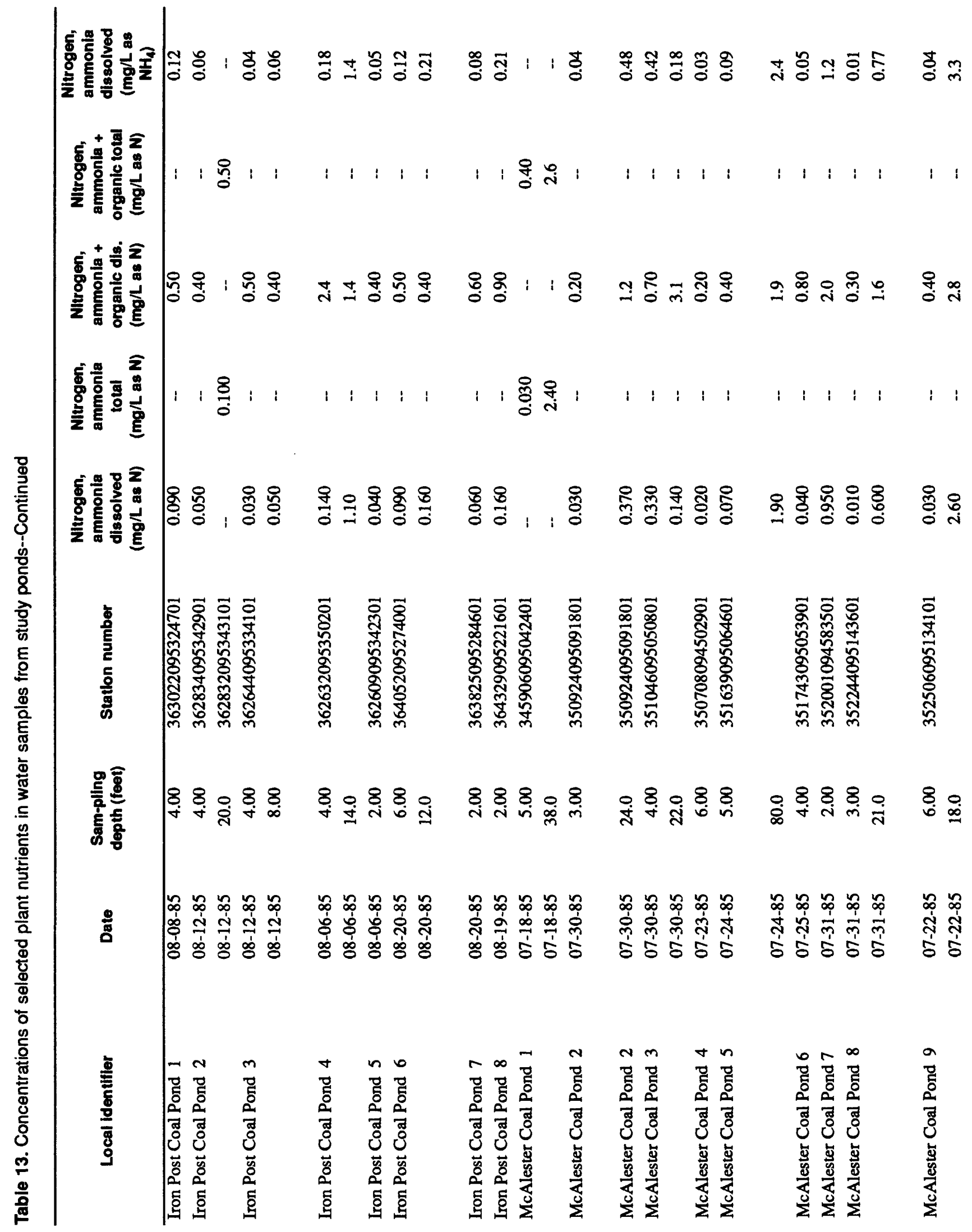




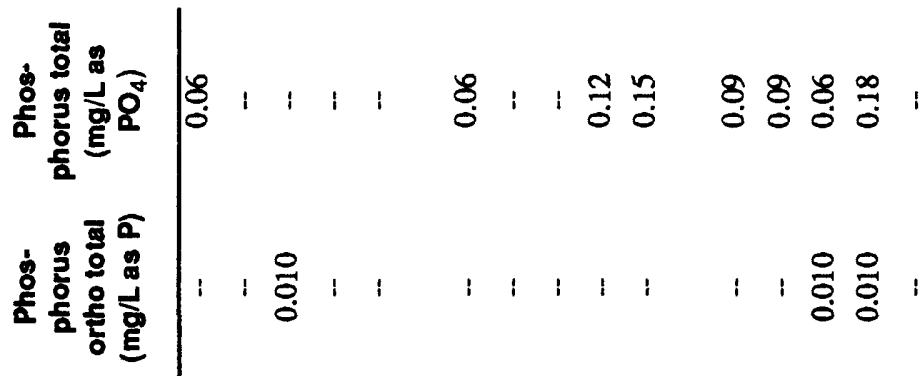

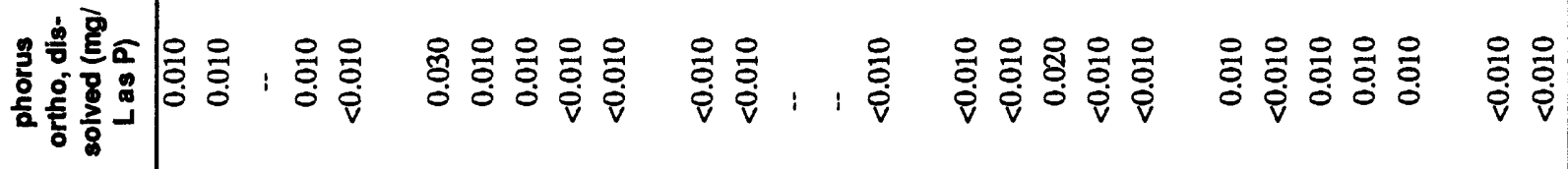

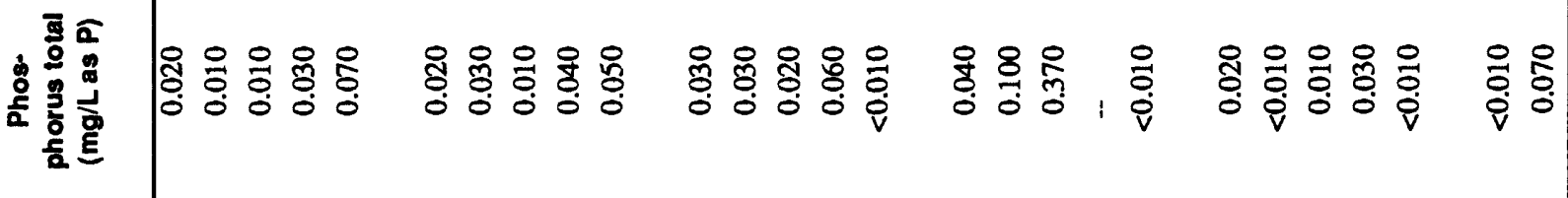

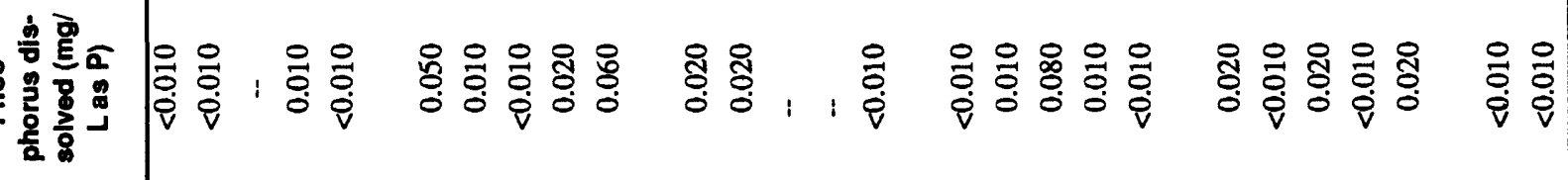

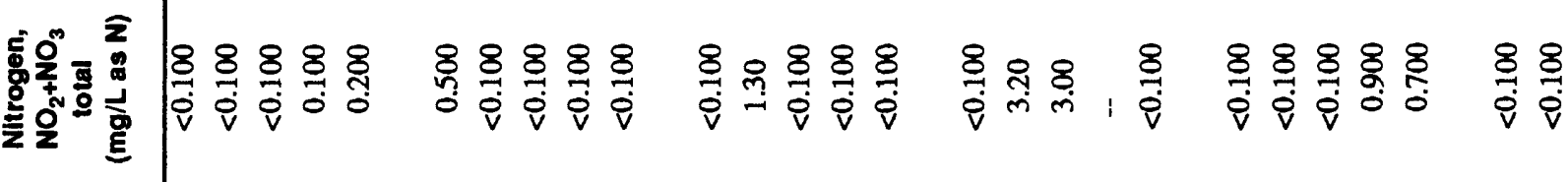

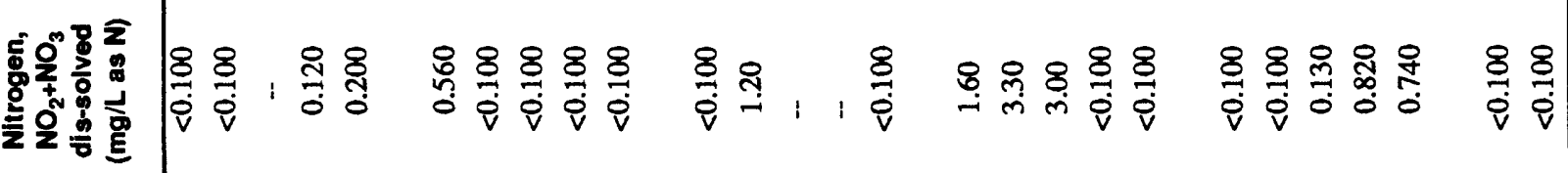

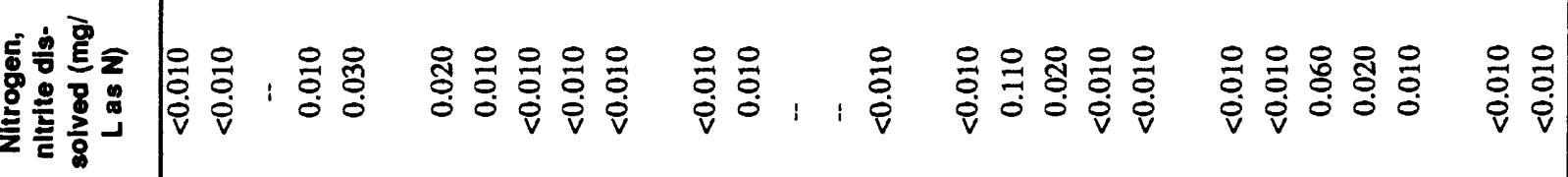

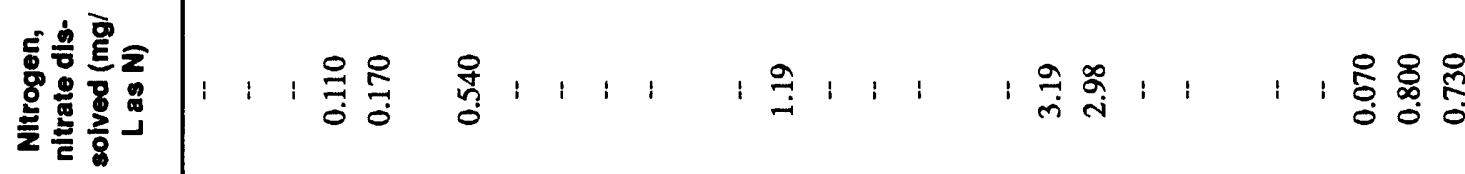

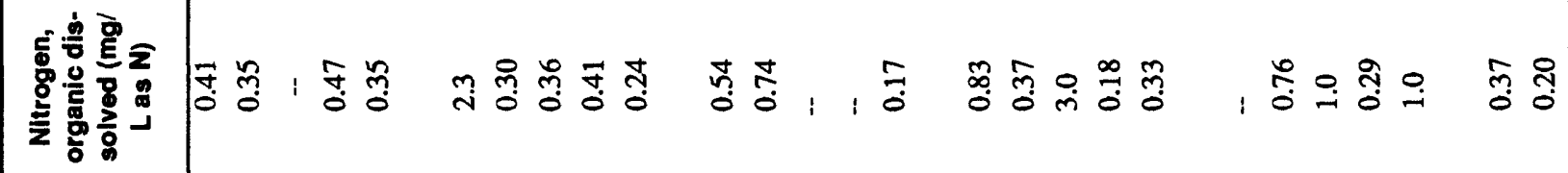

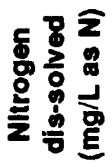

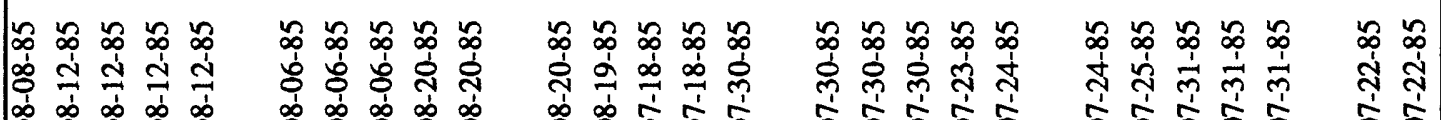
\% \&ி \& \& 


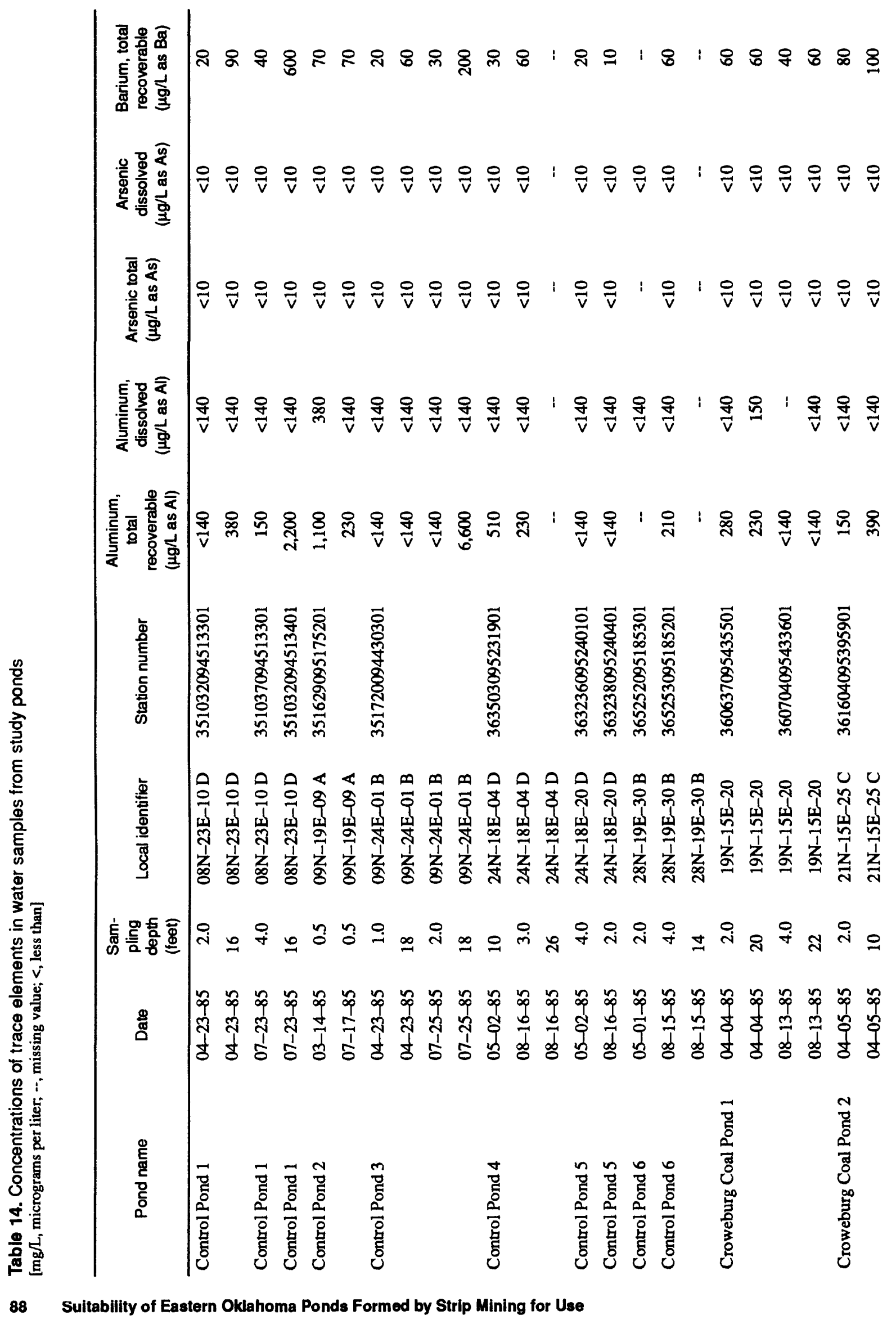




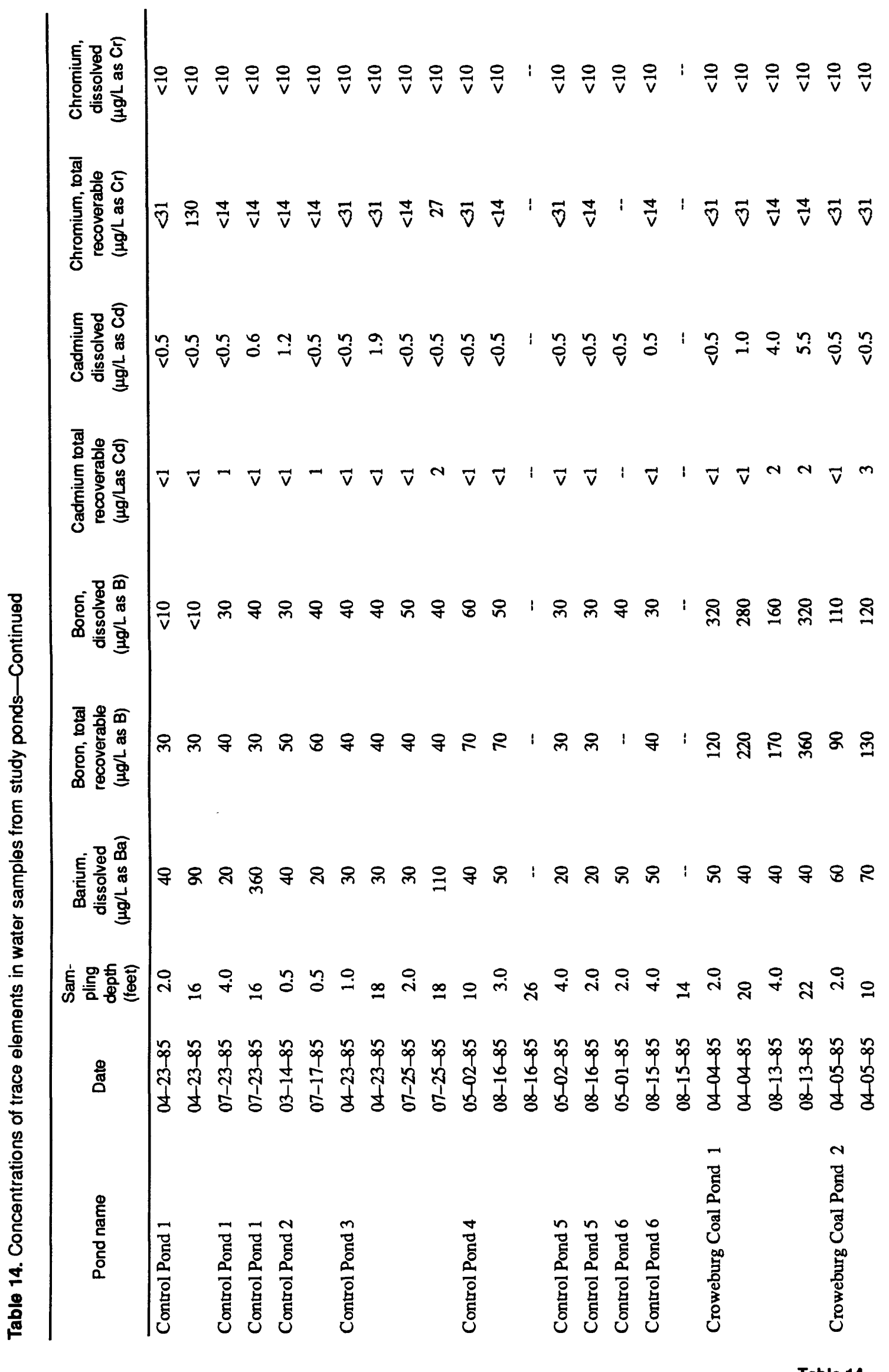




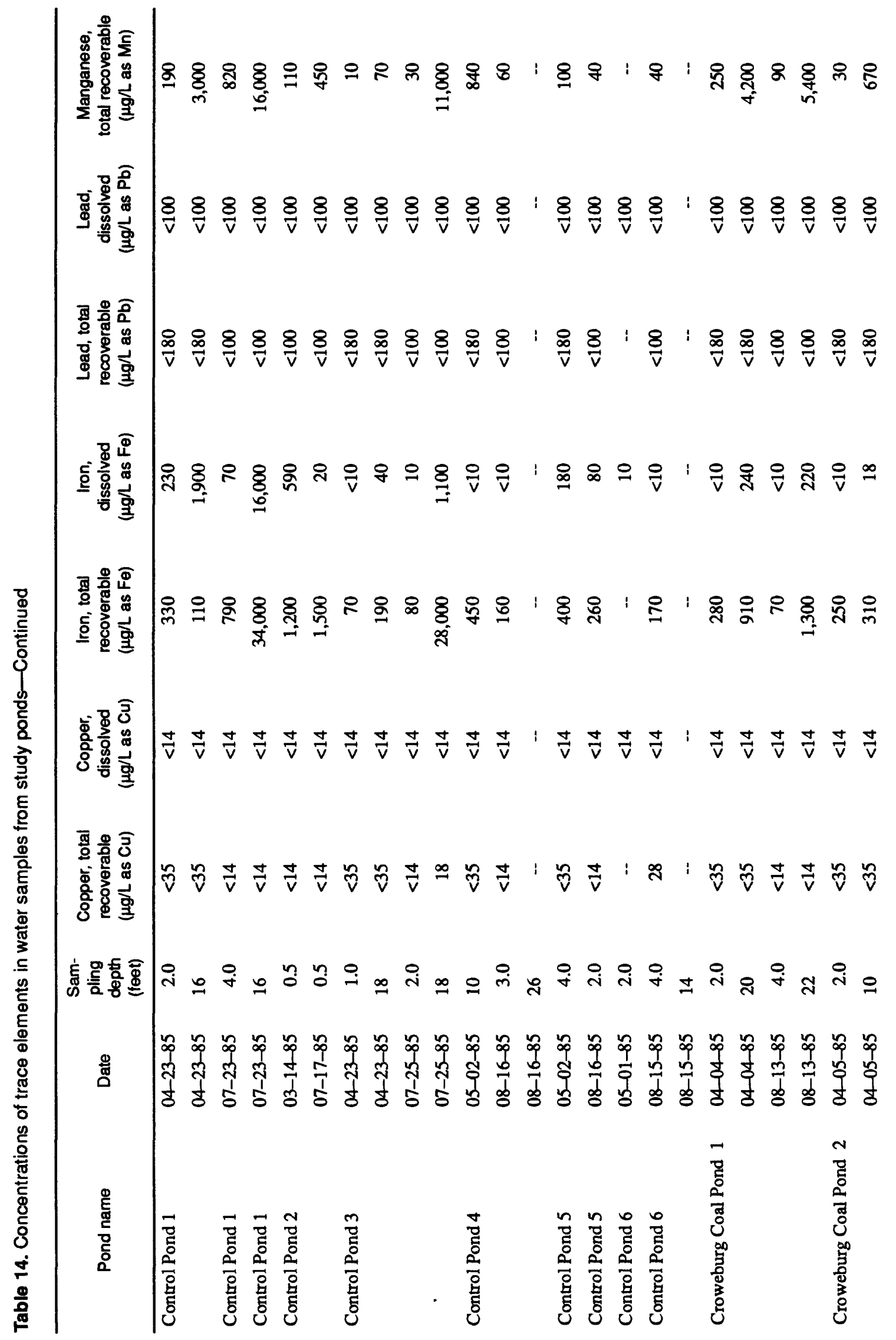




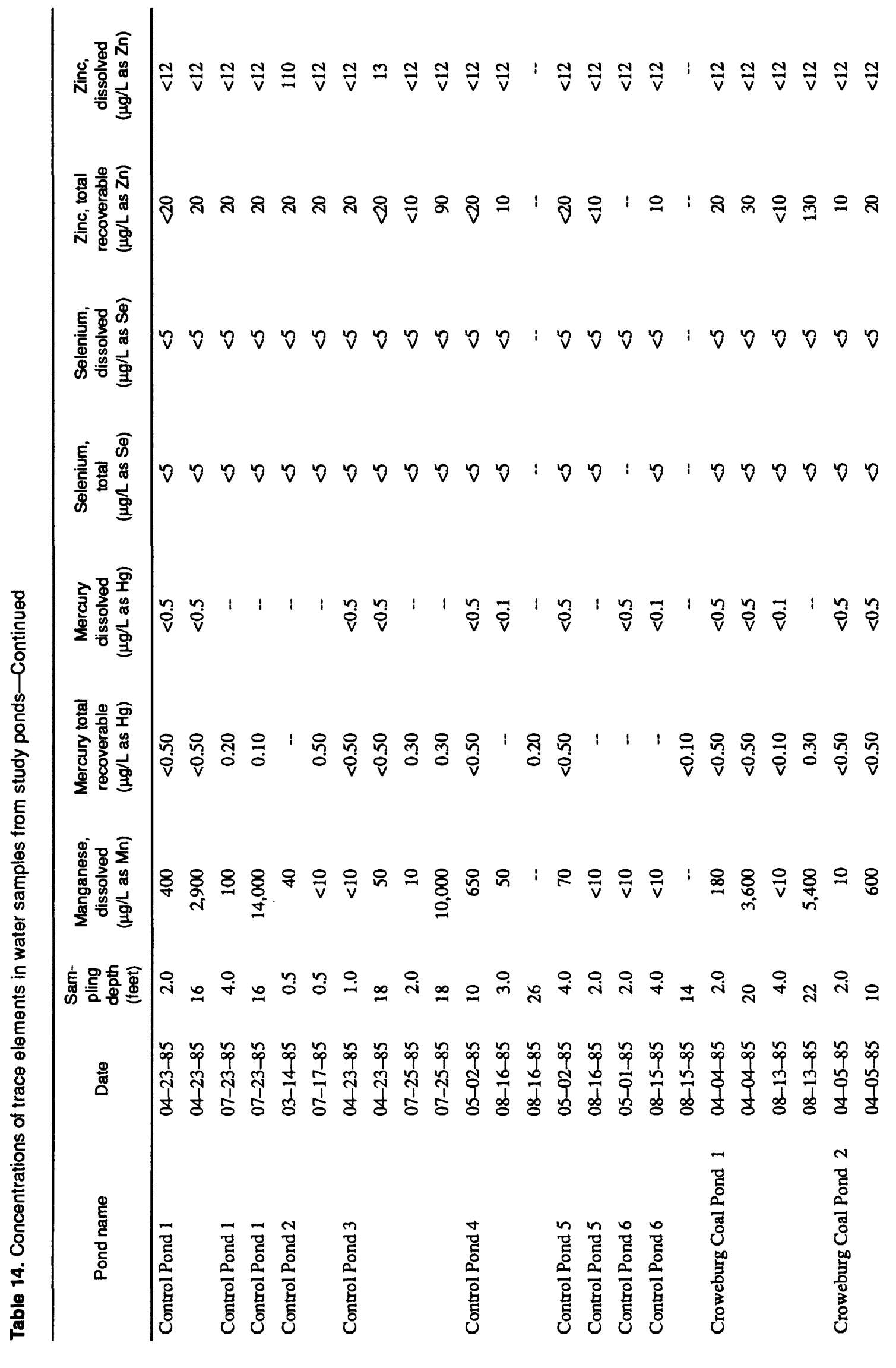




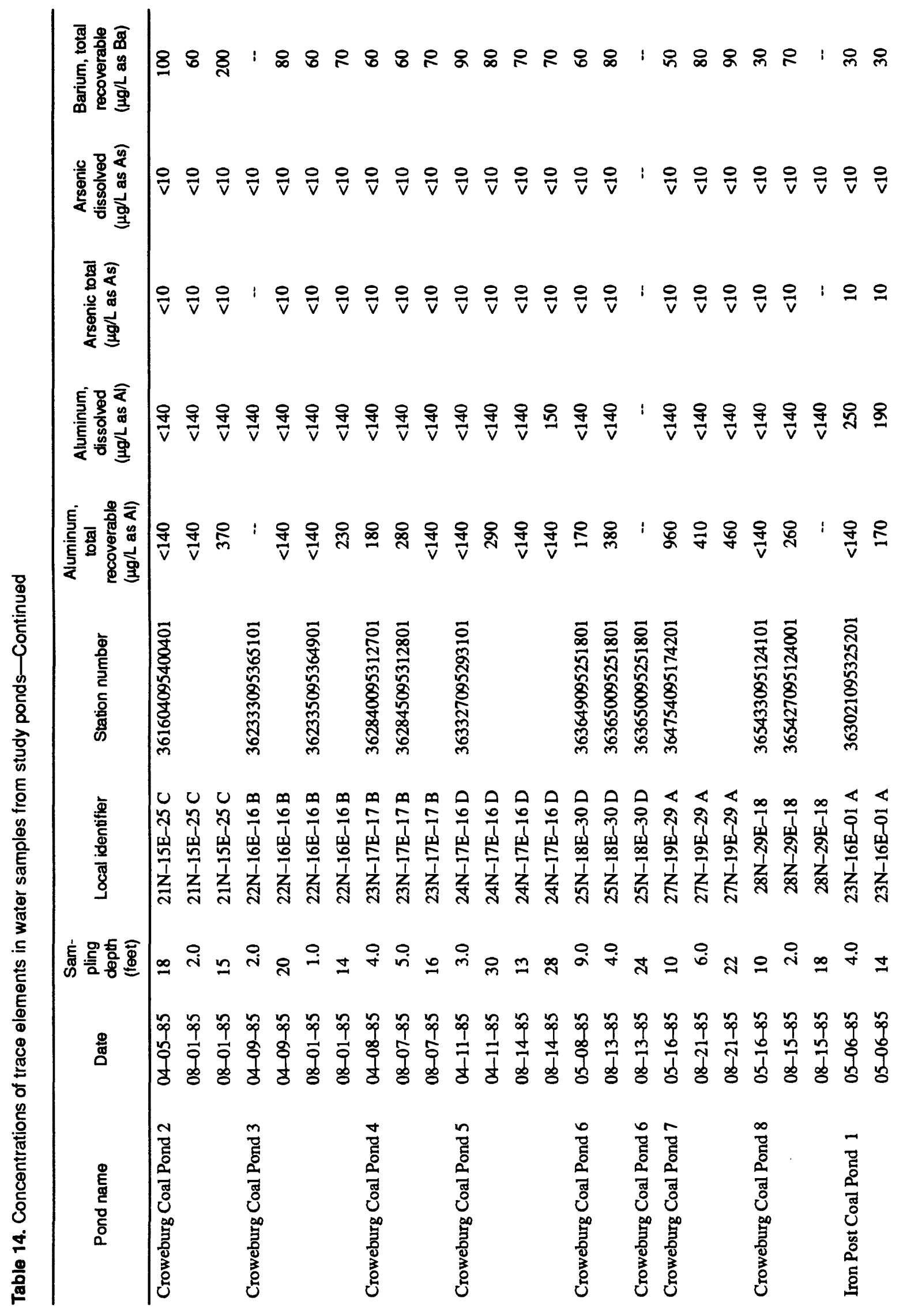




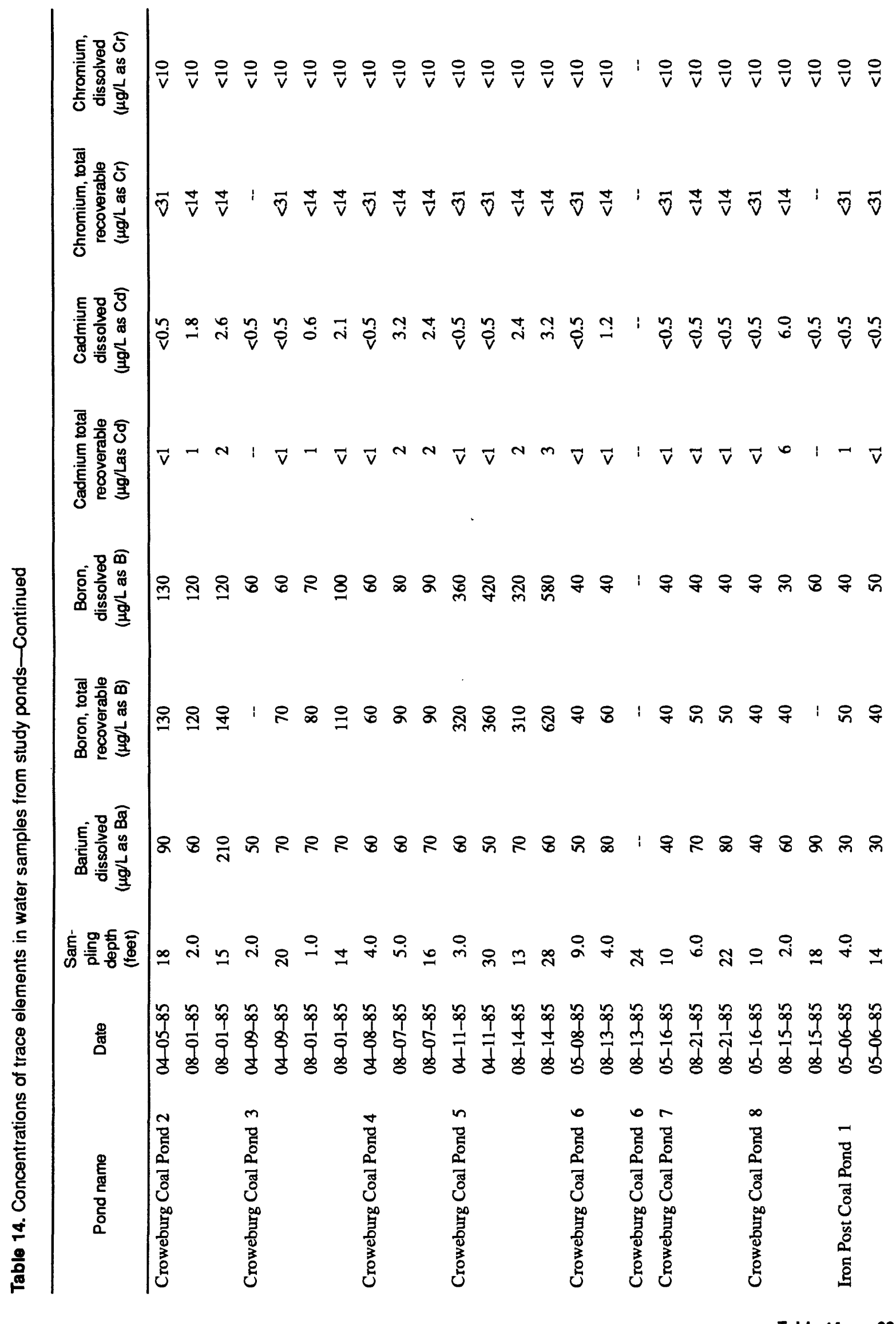




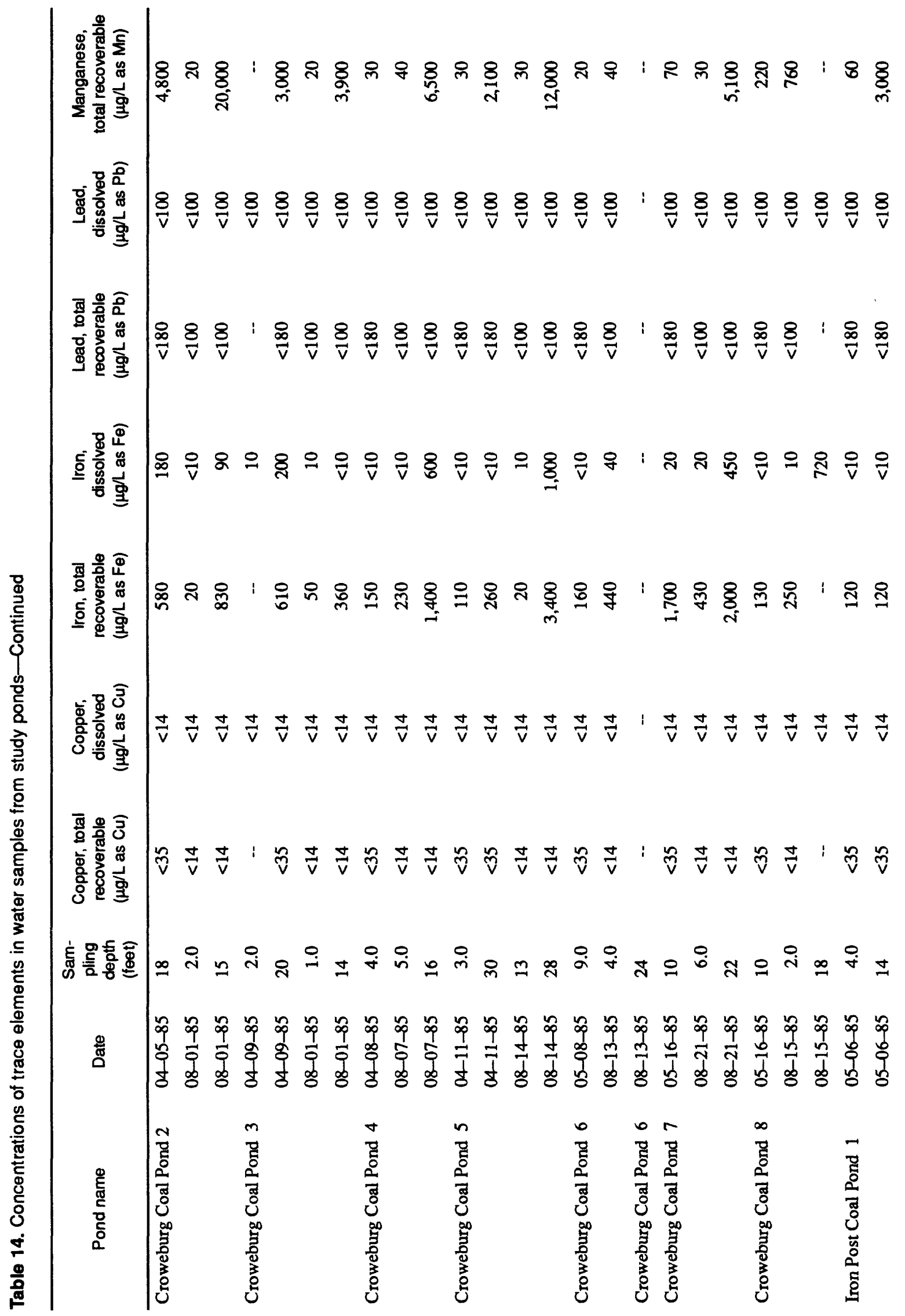




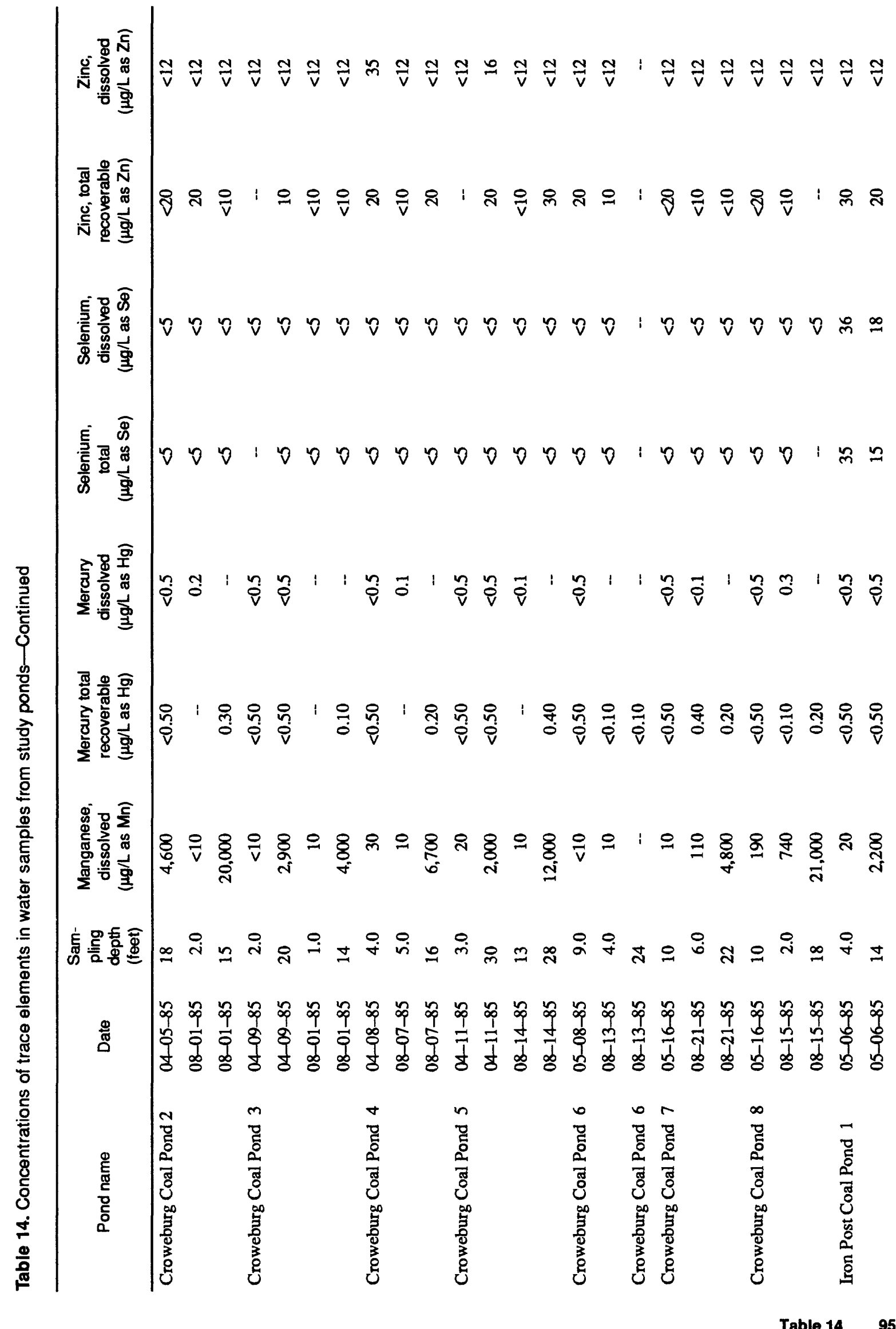




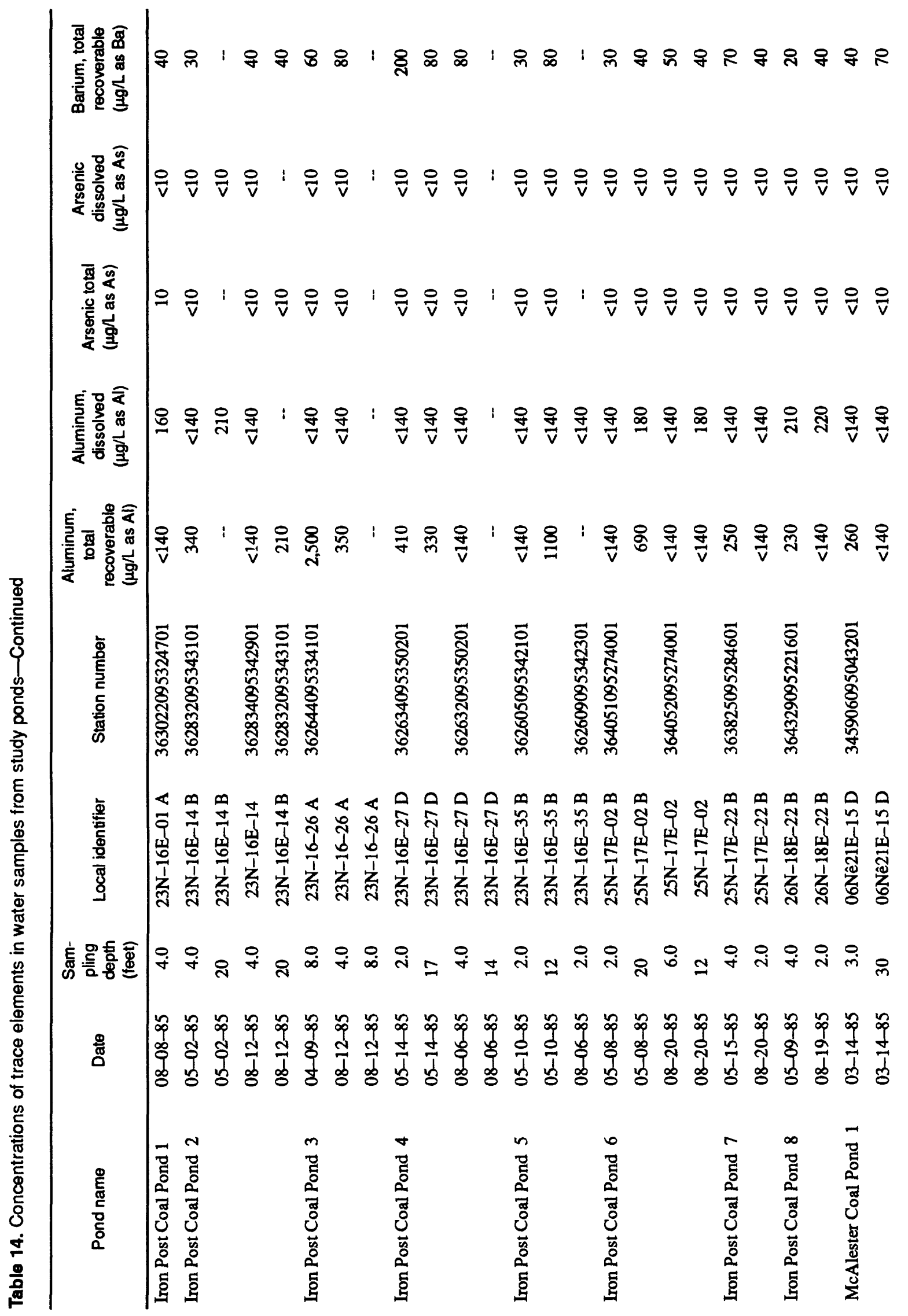




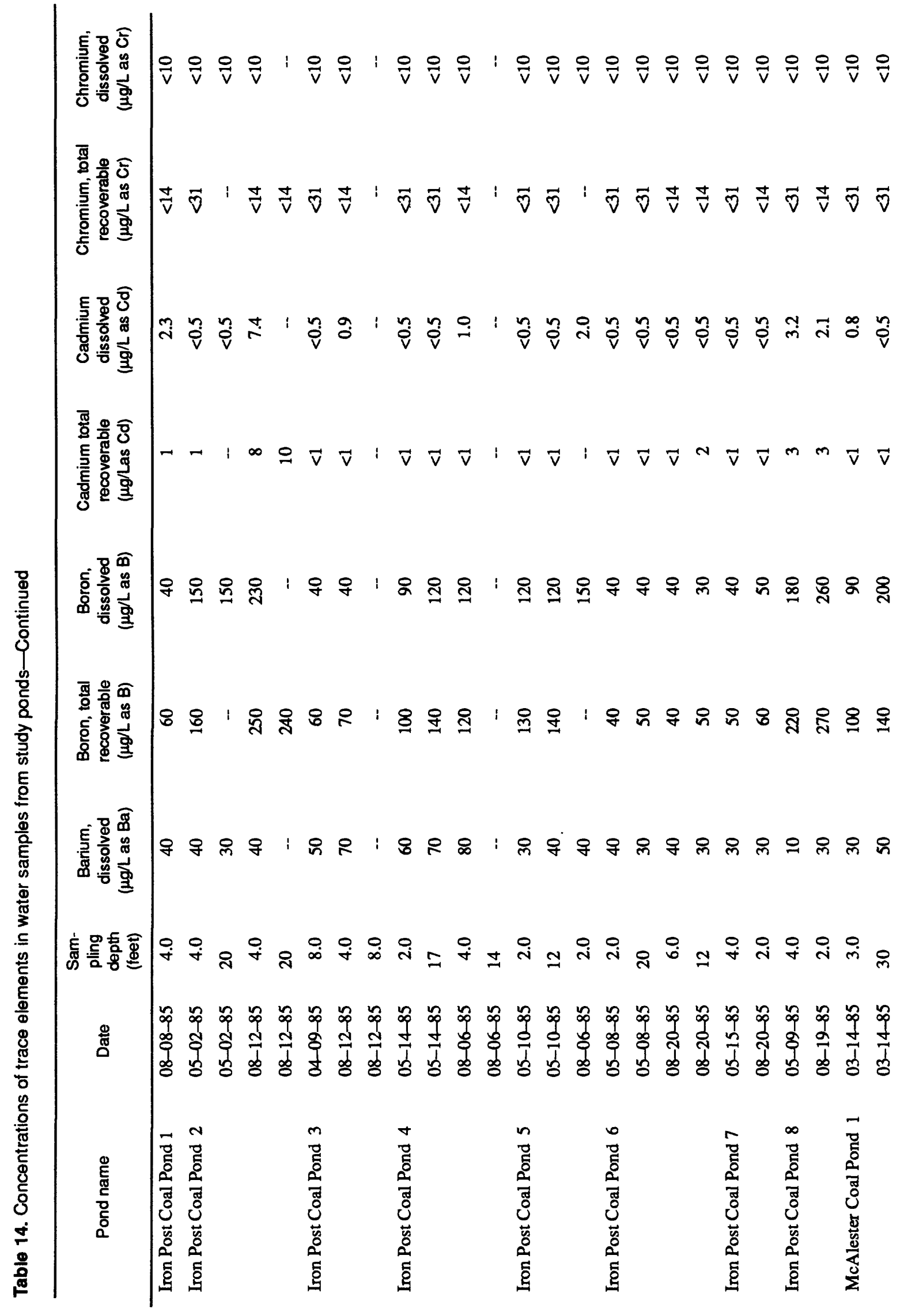




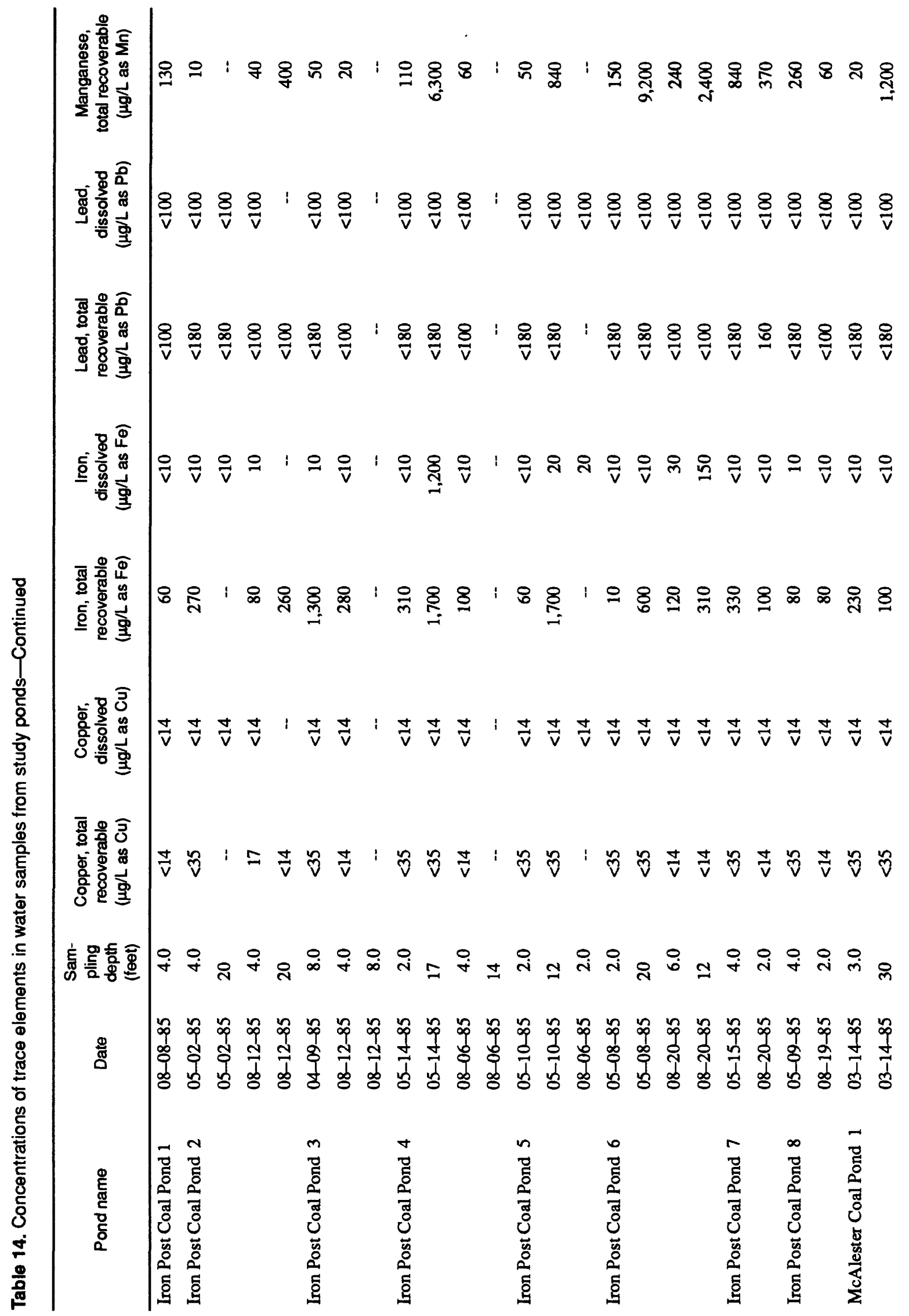




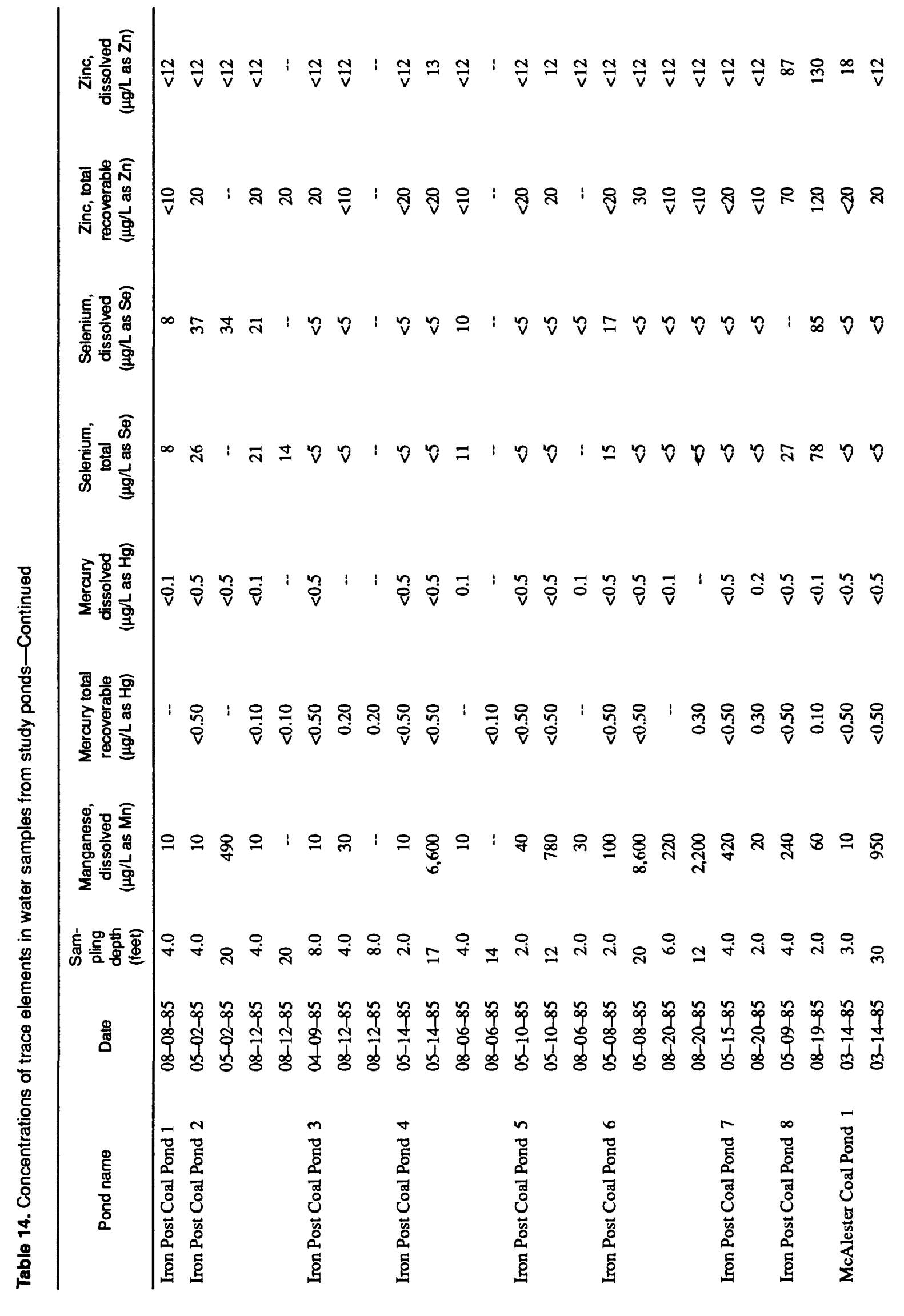




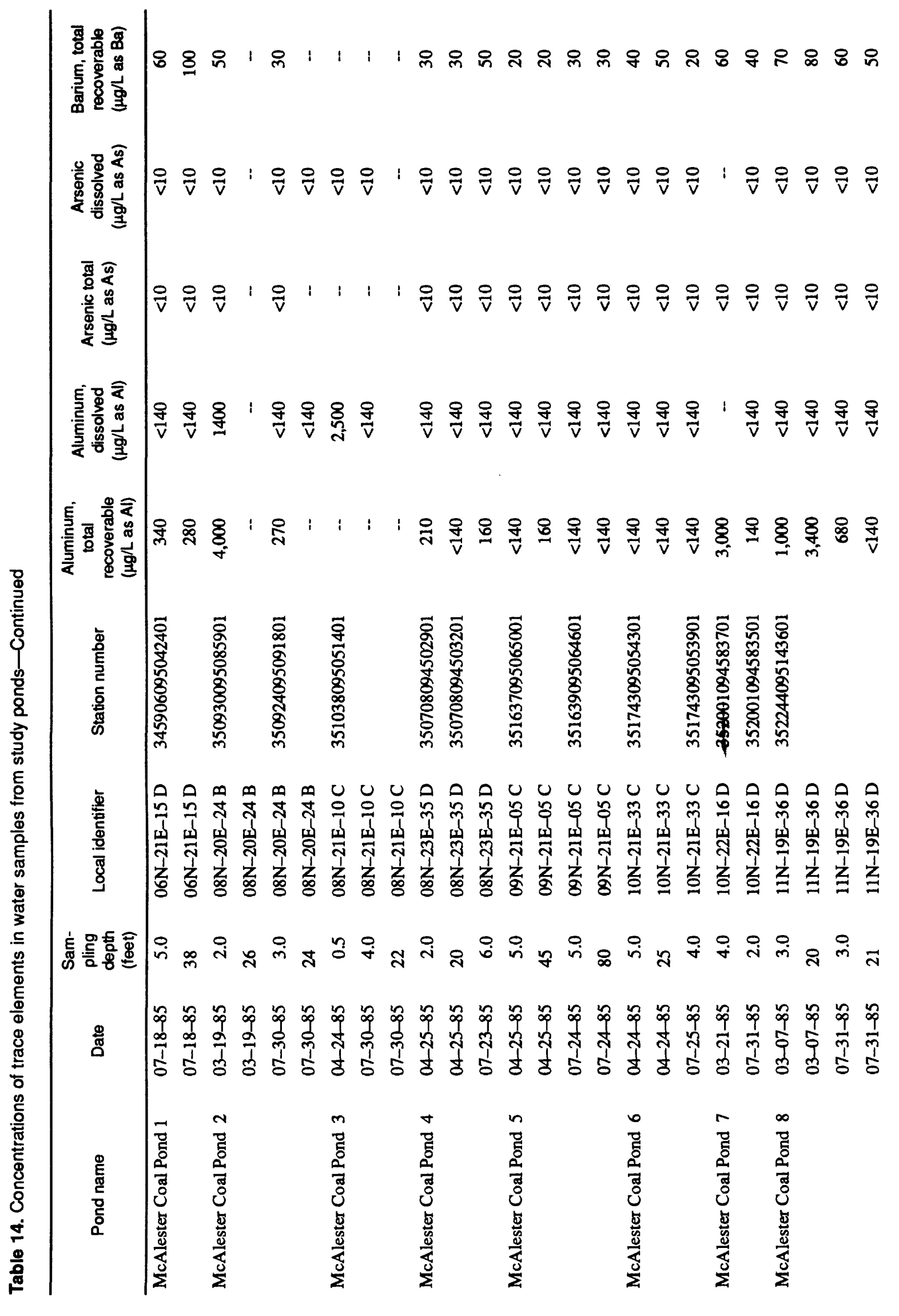




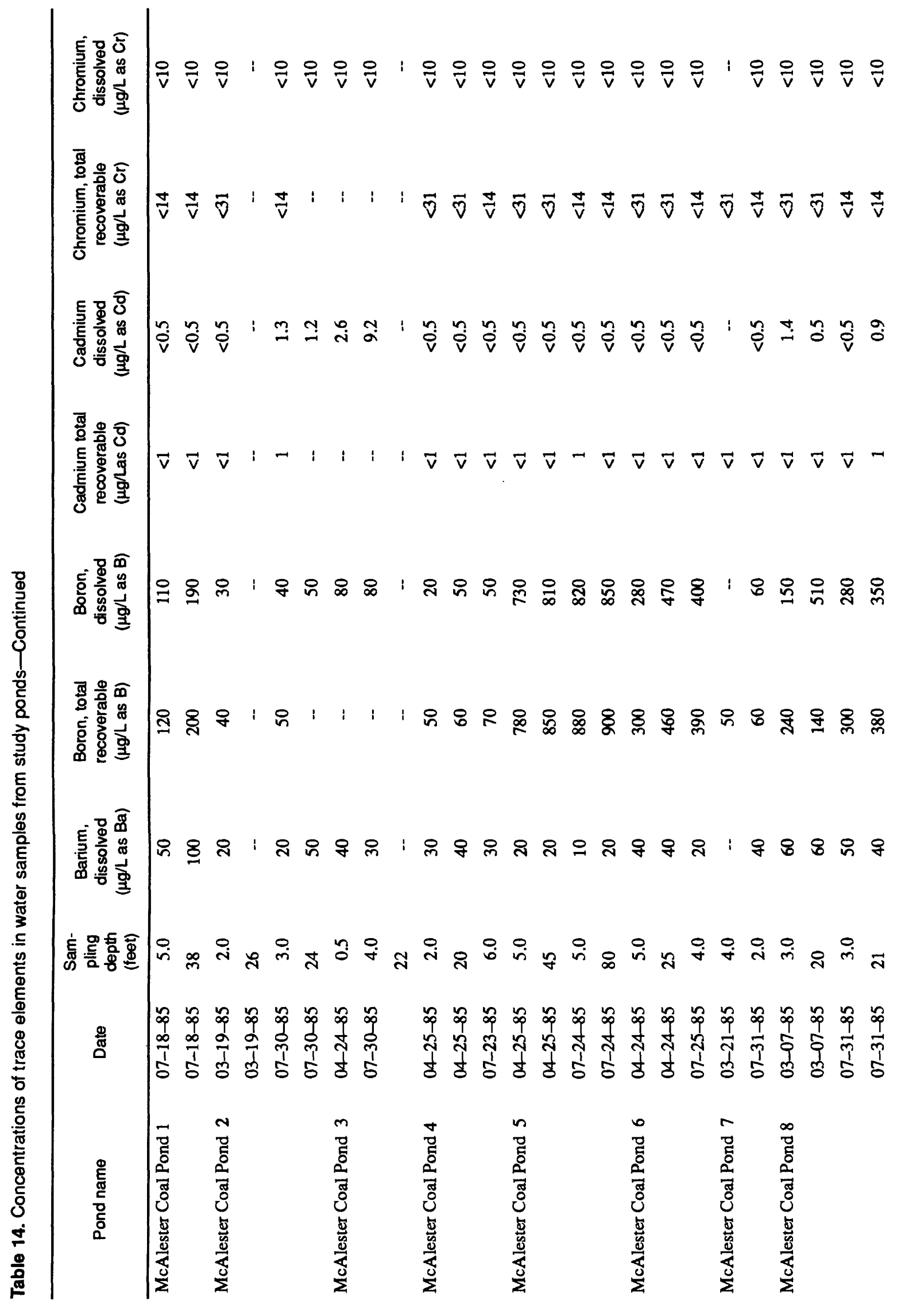




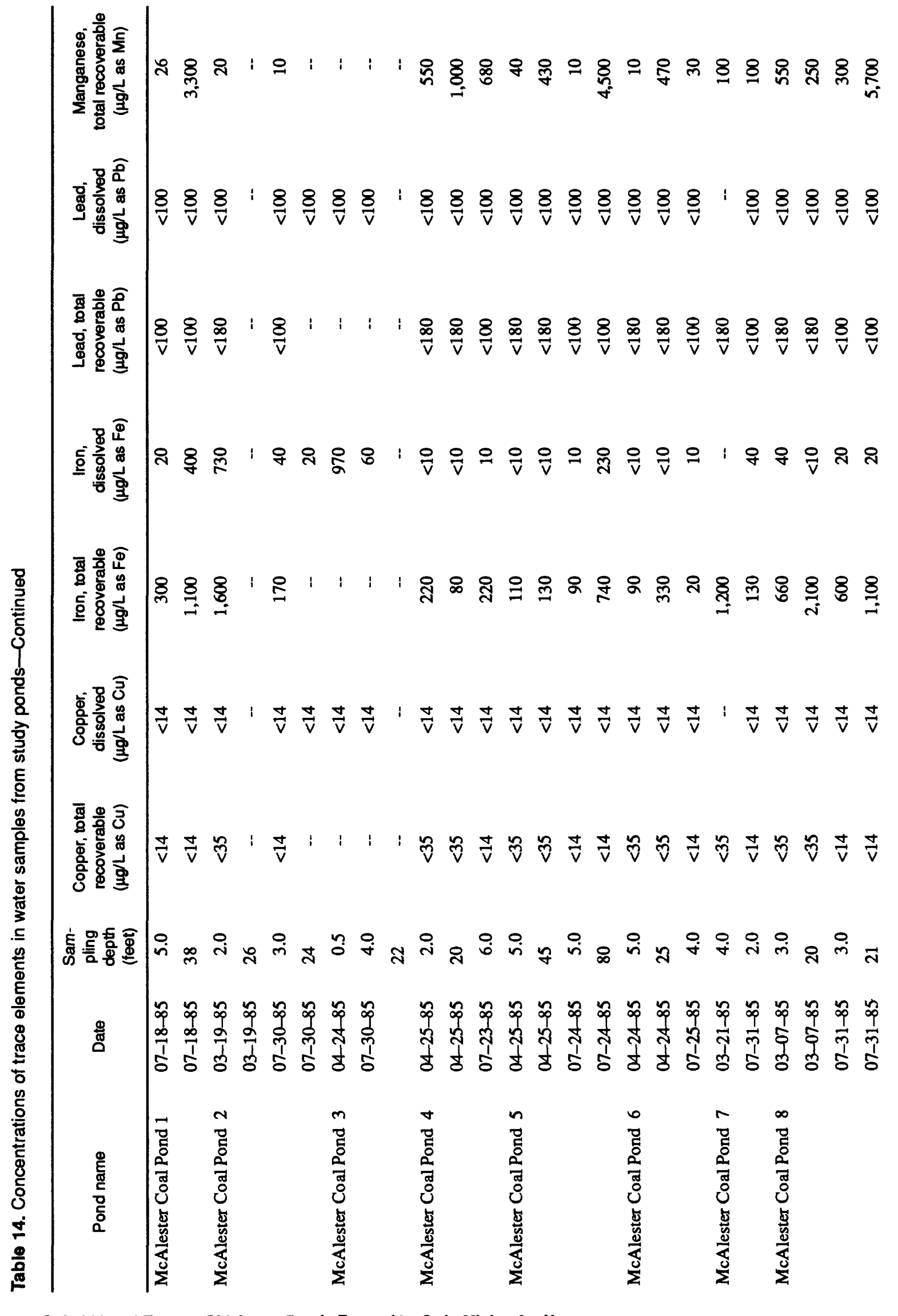




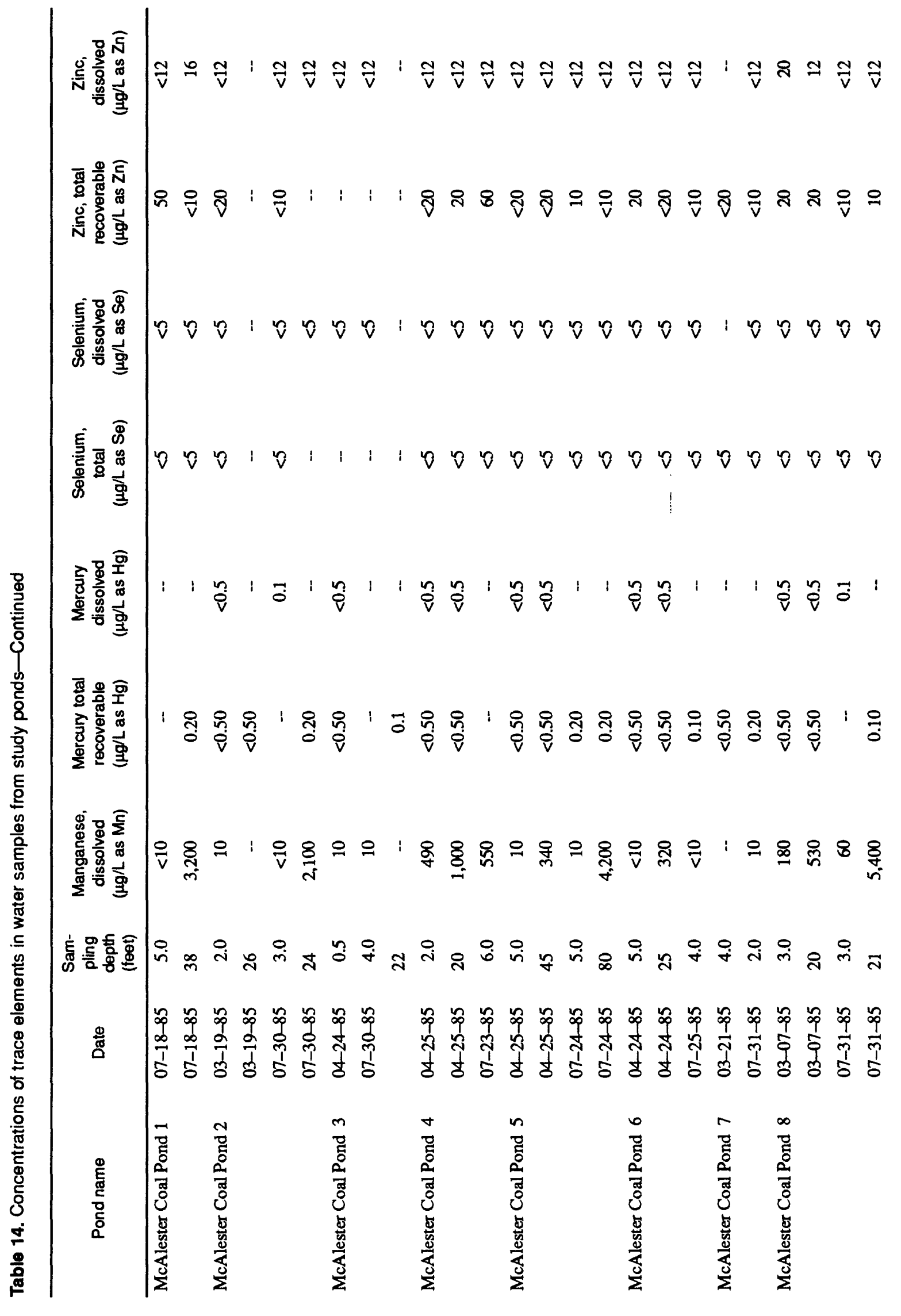




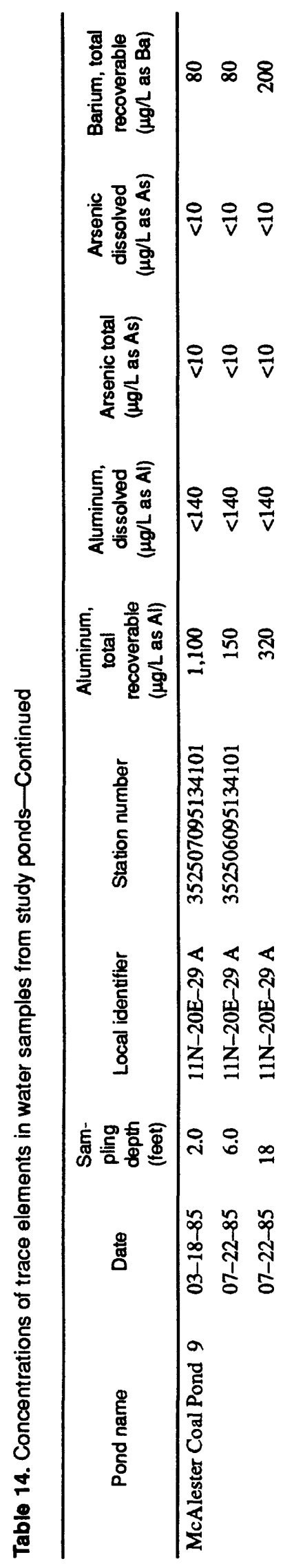




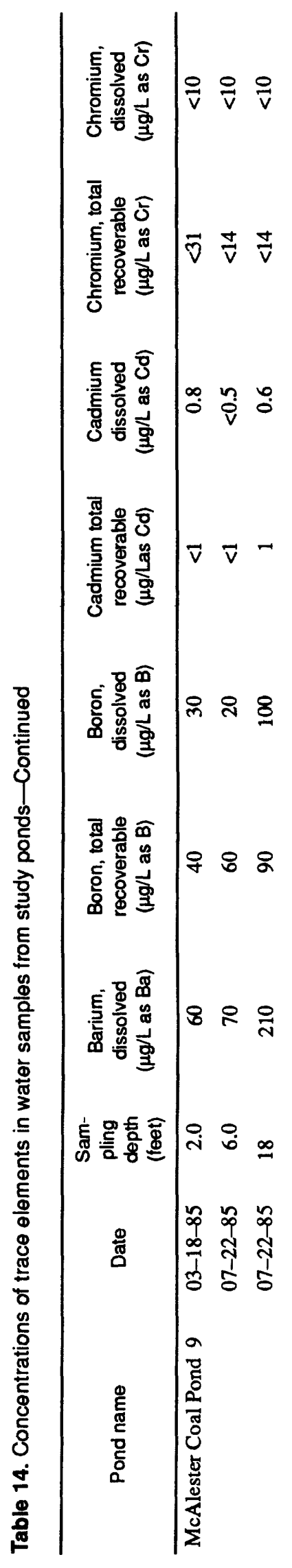




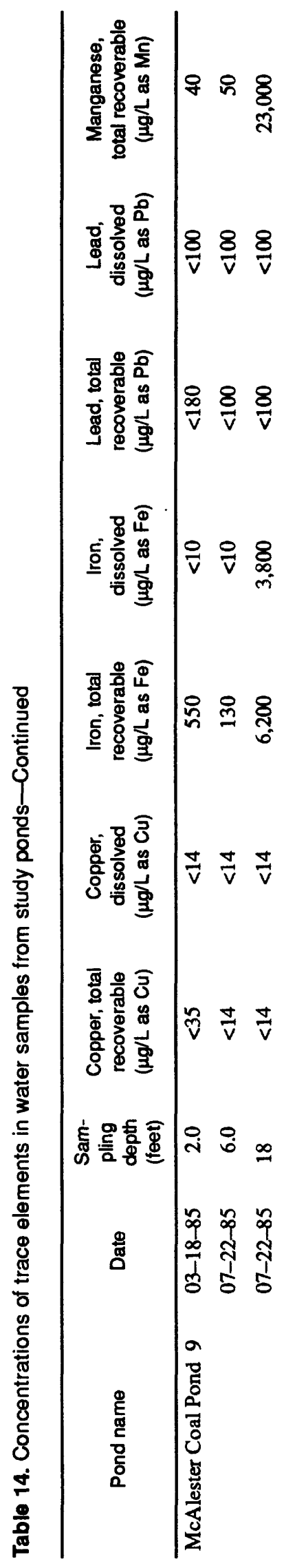




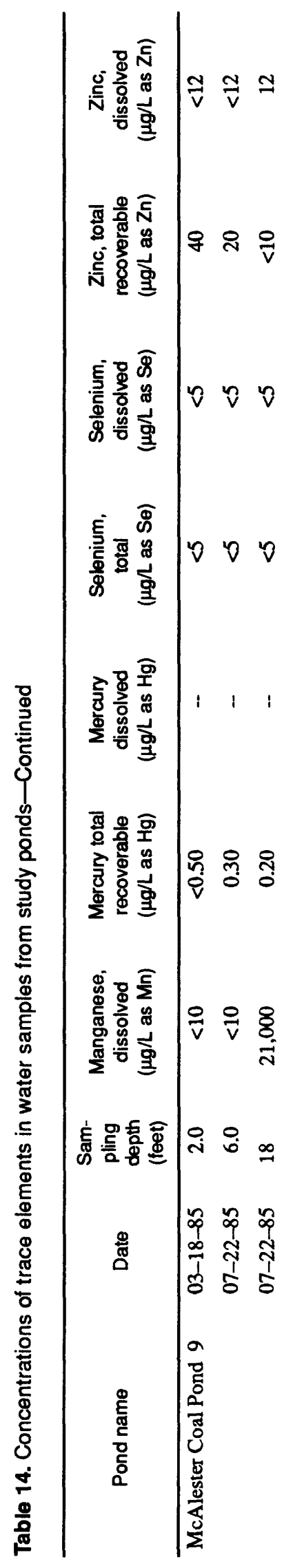




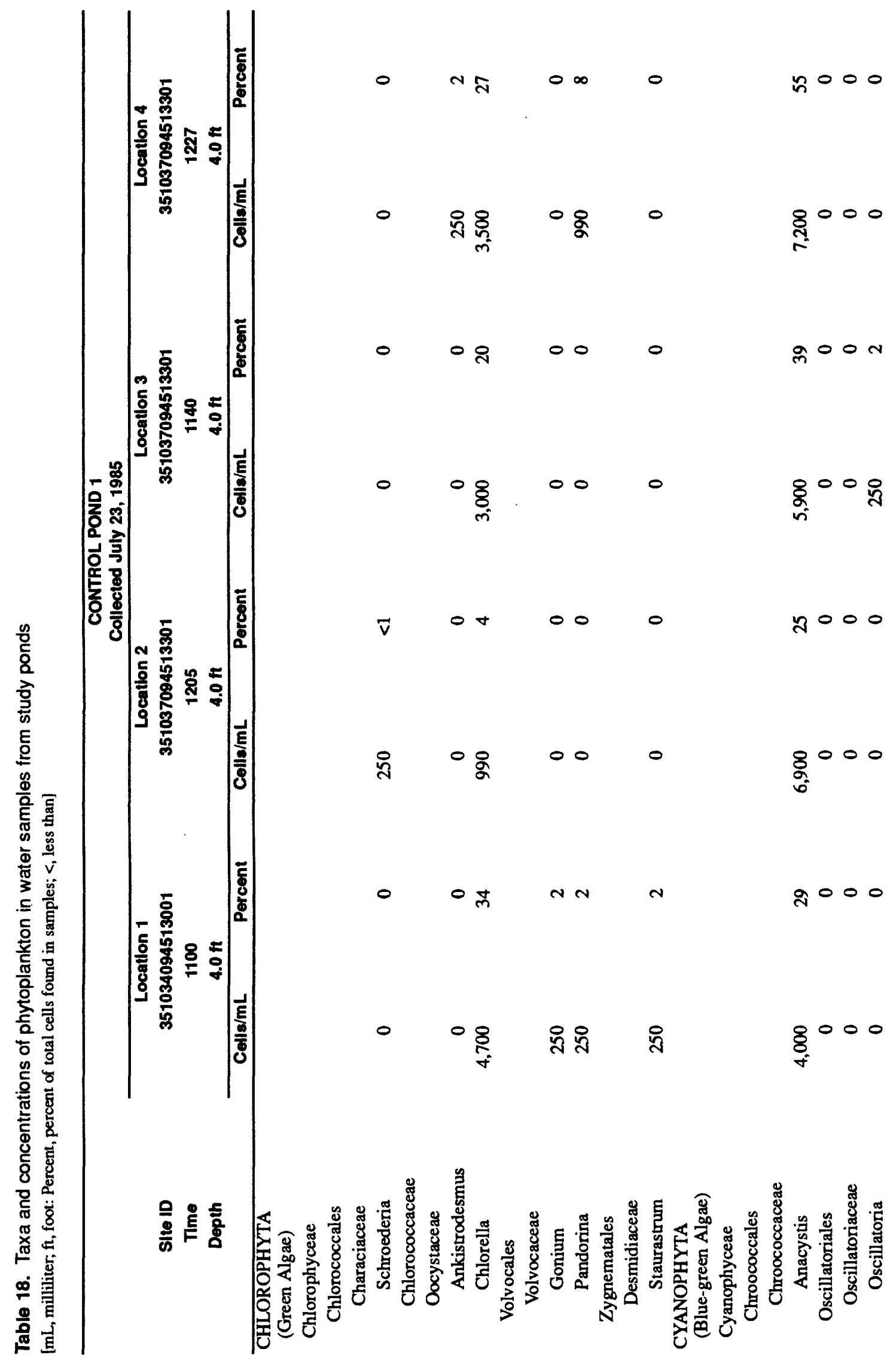




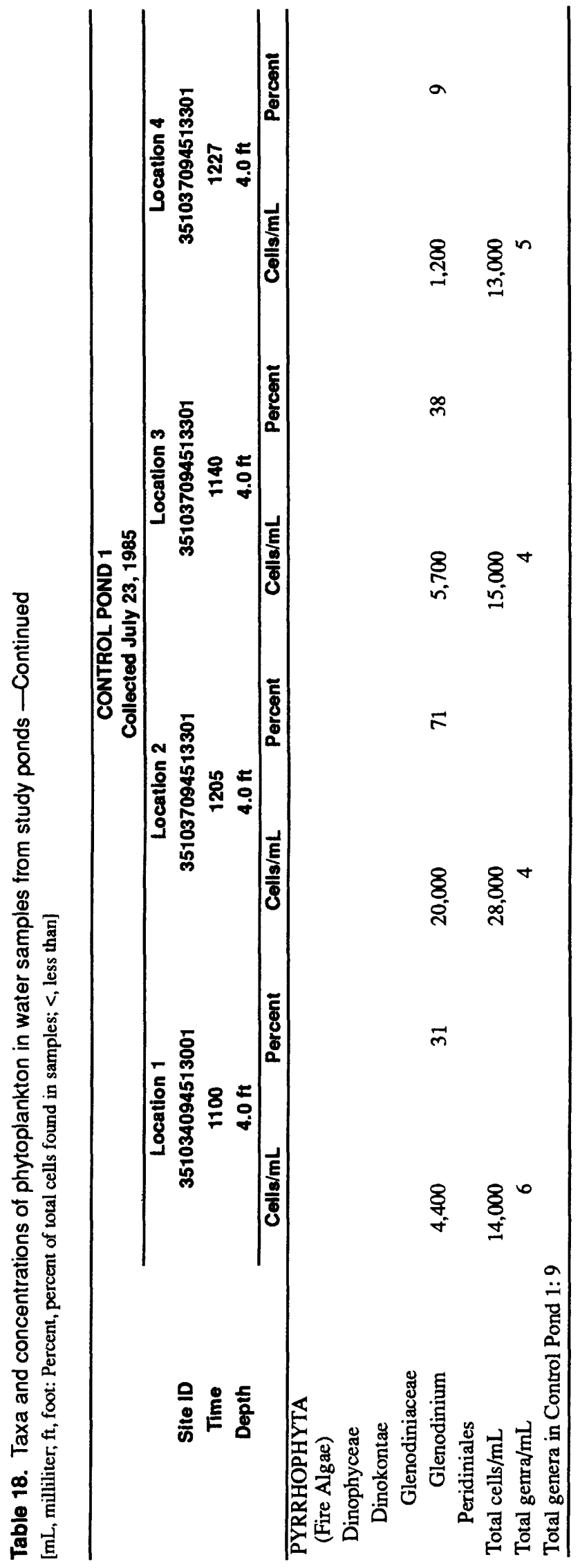




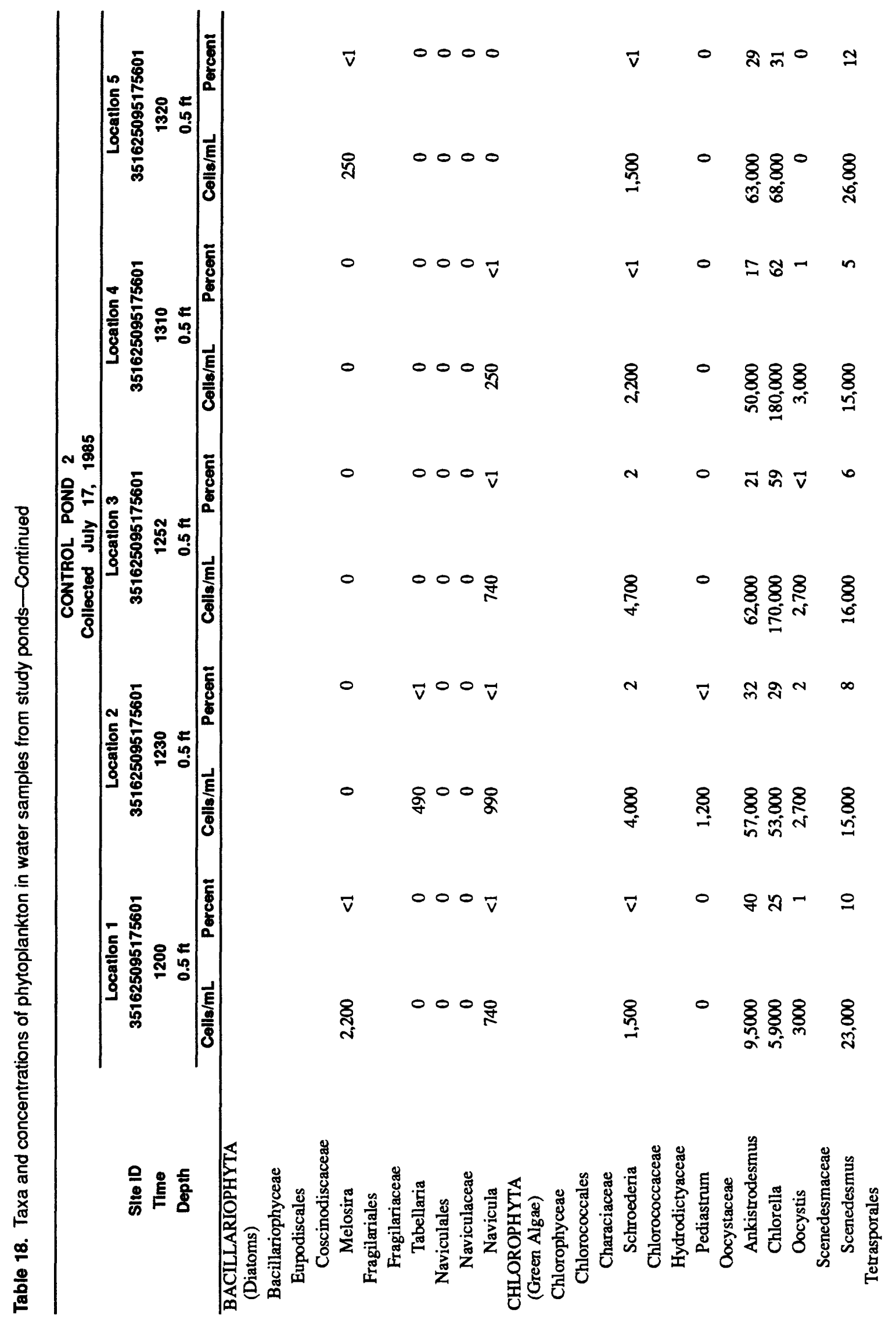




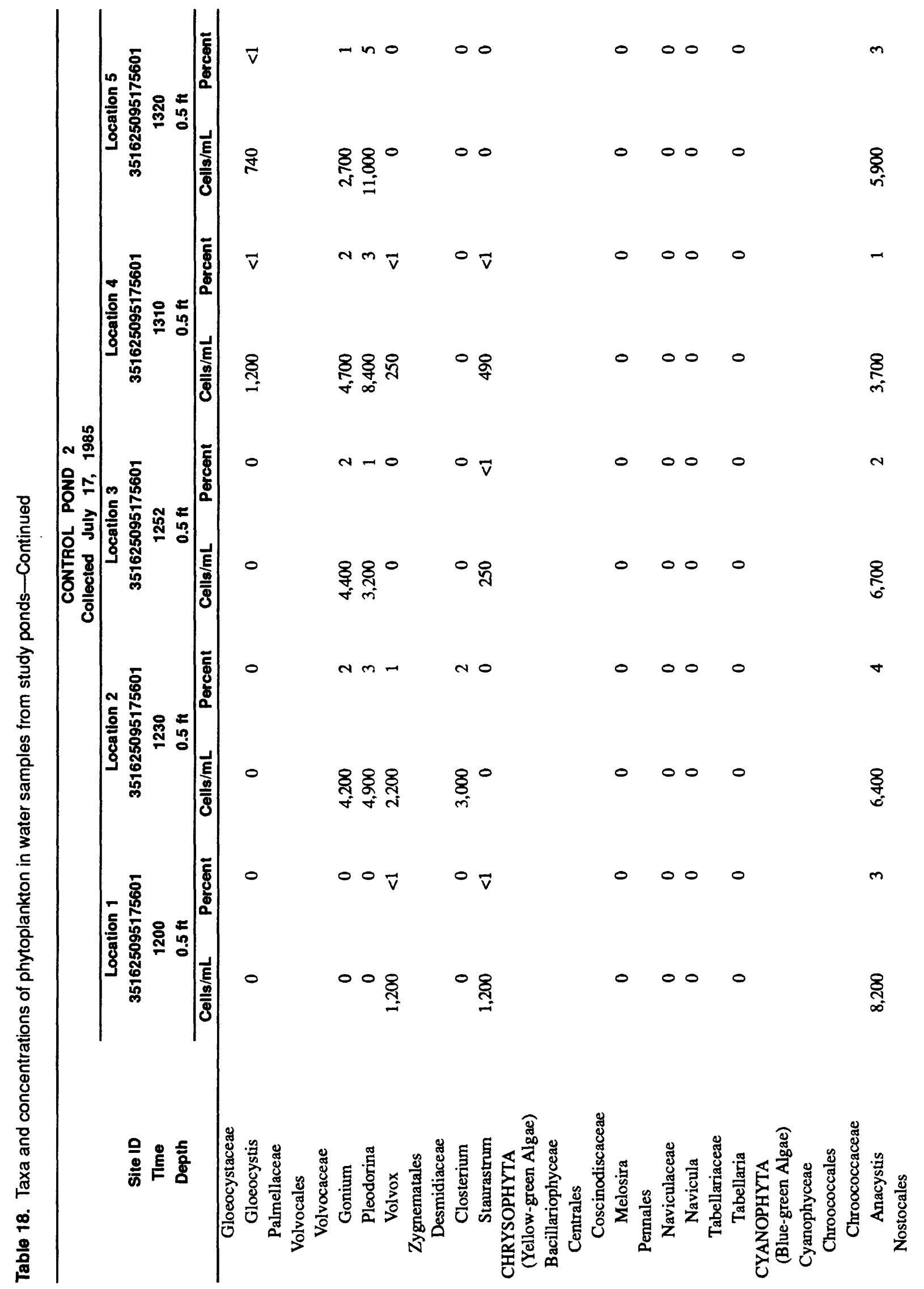




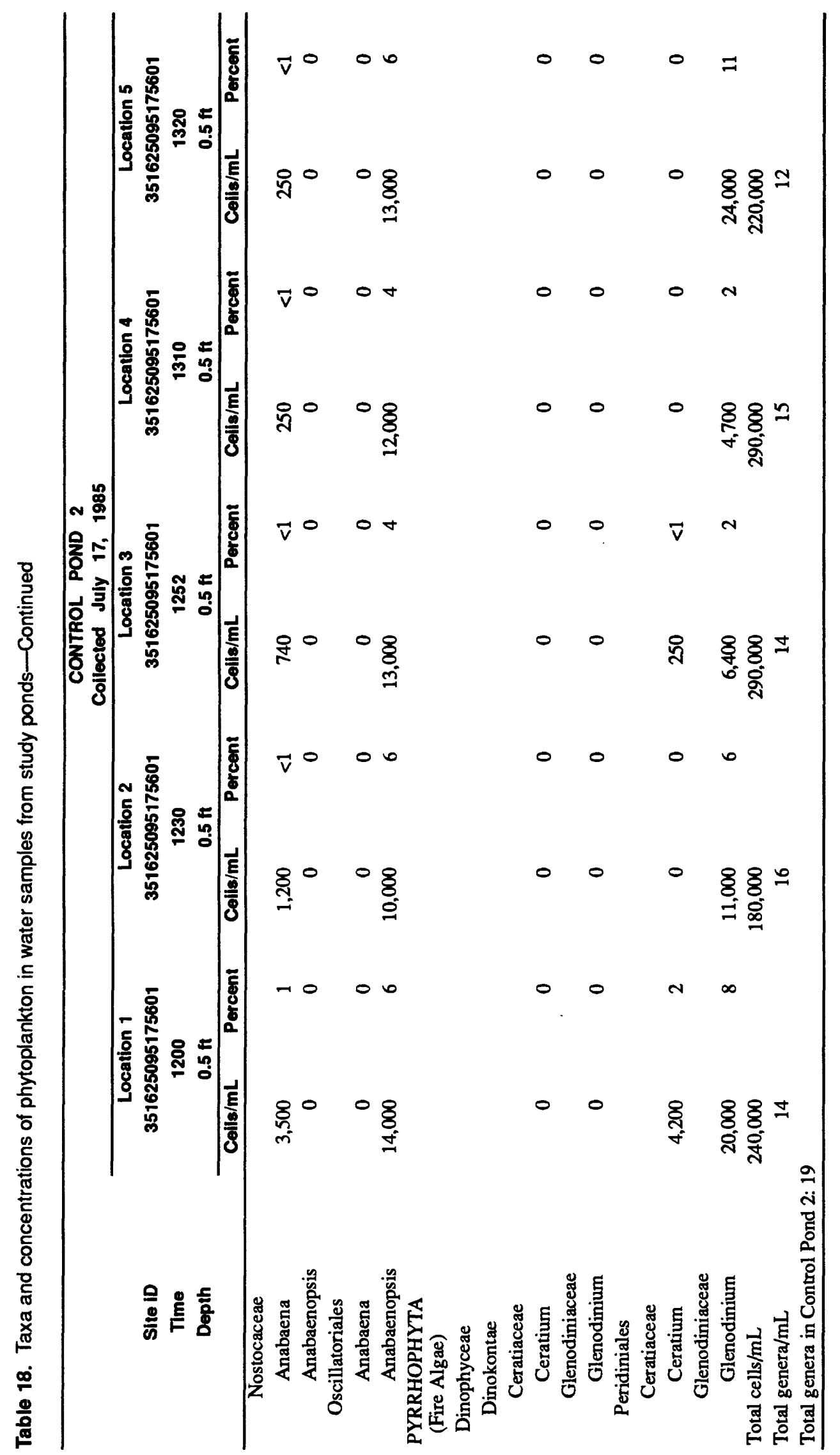




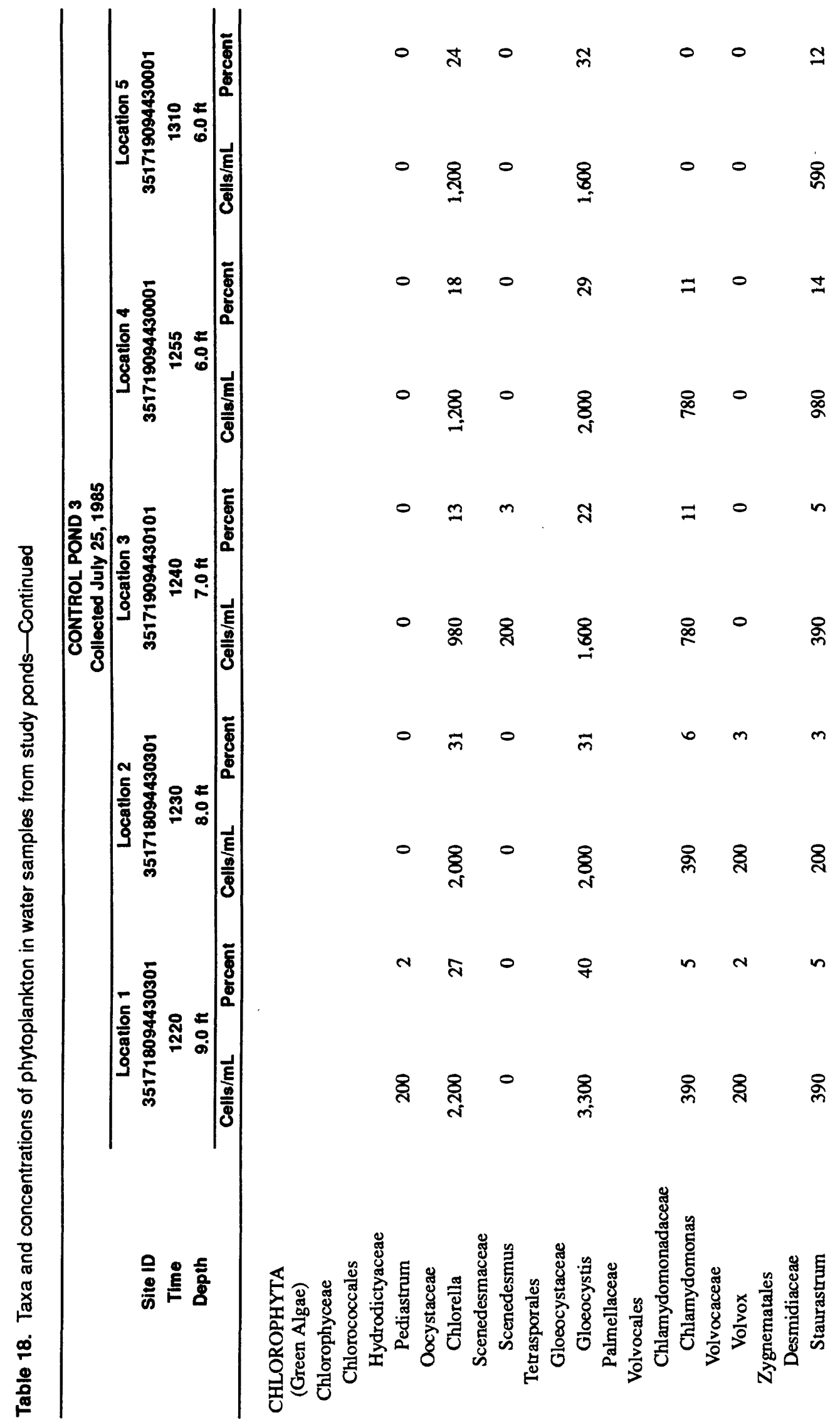




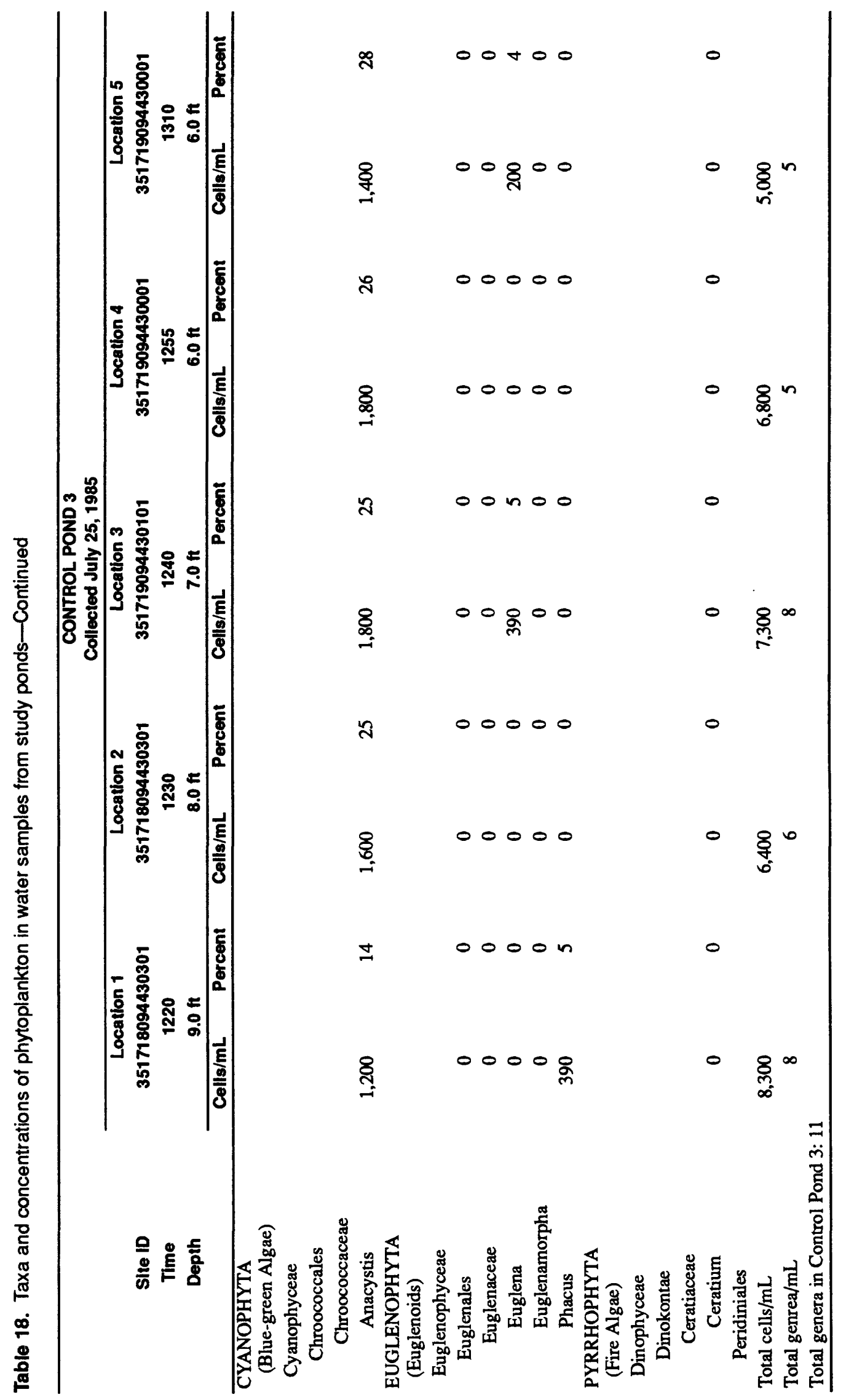




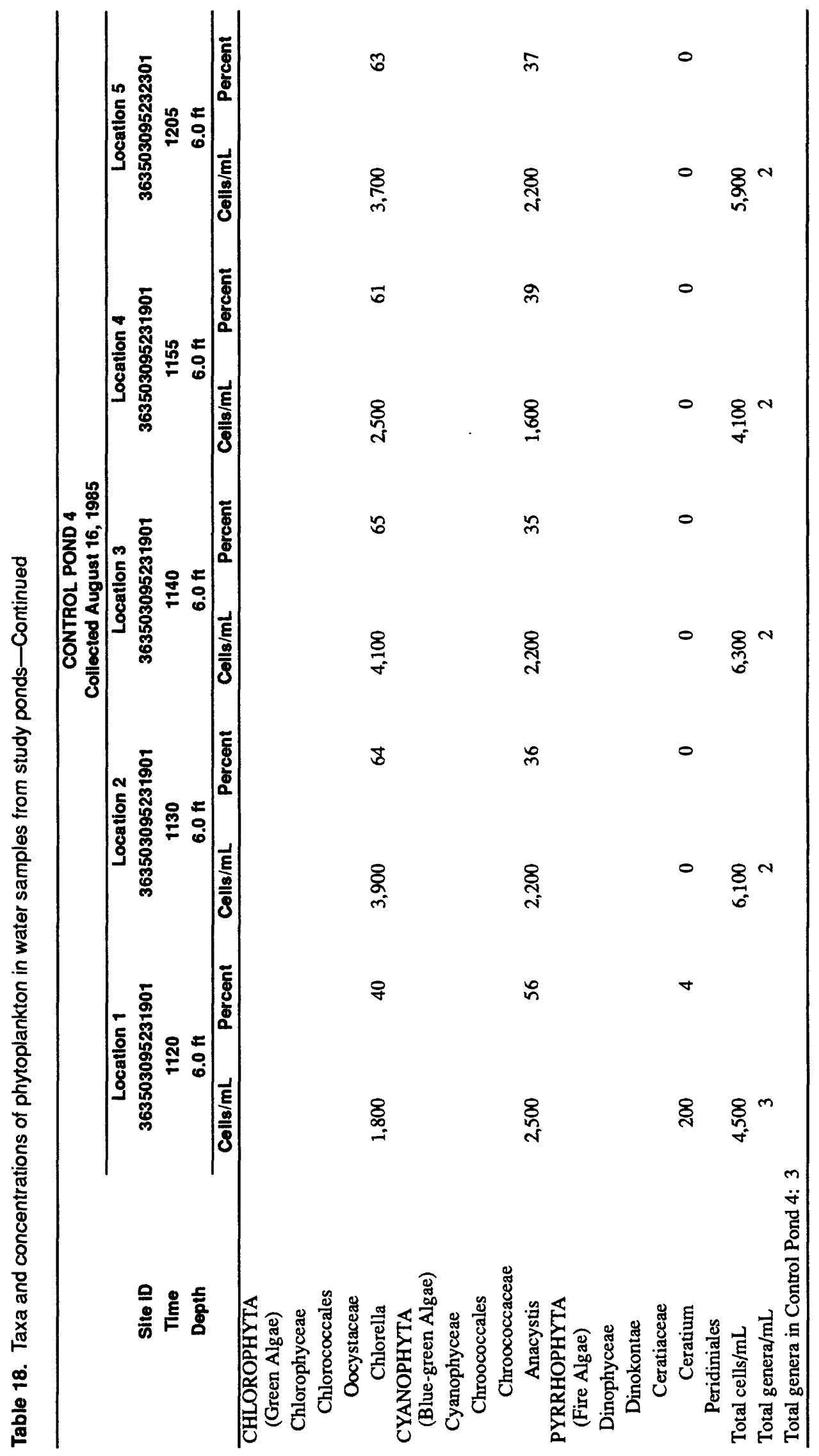




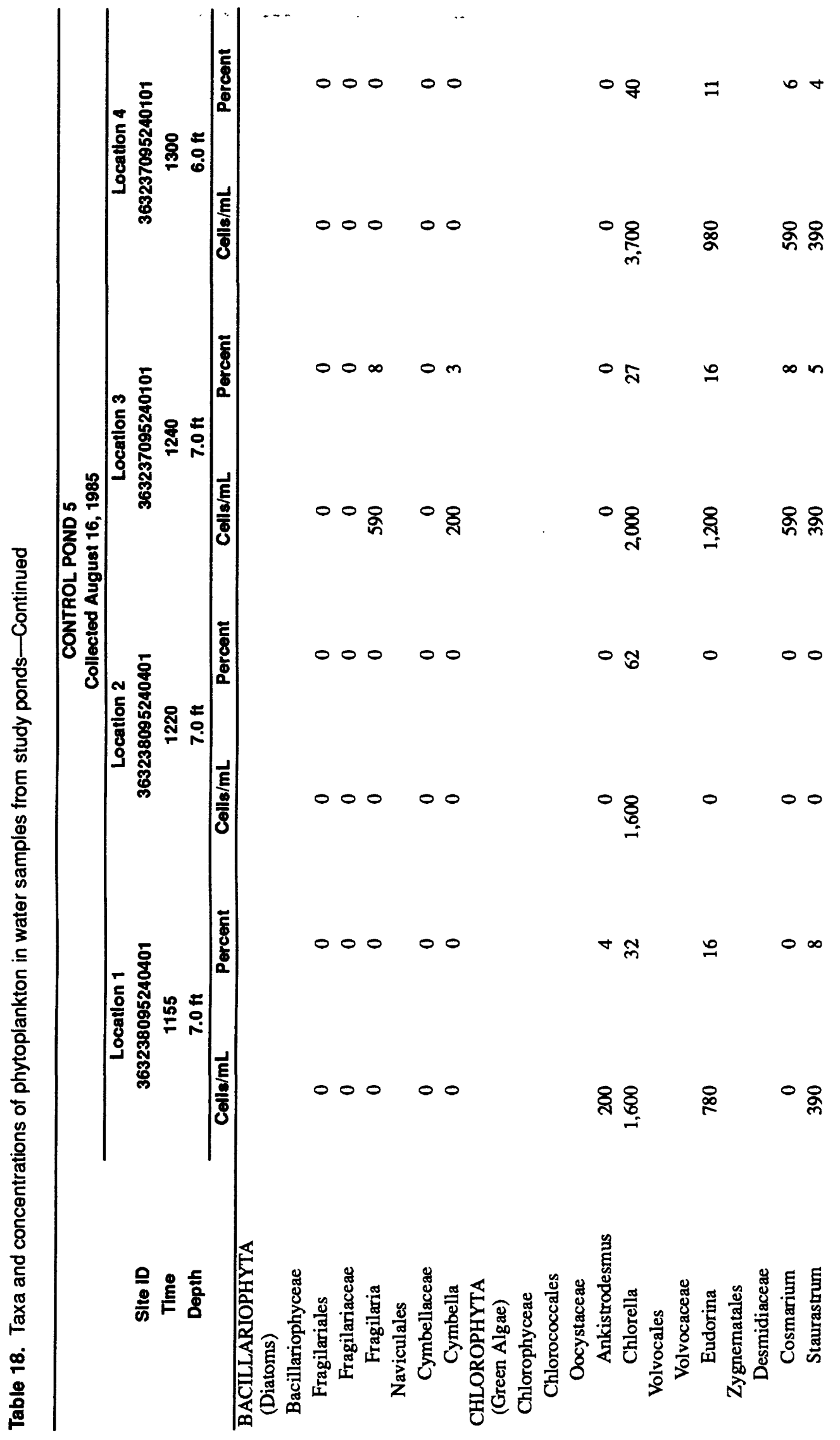




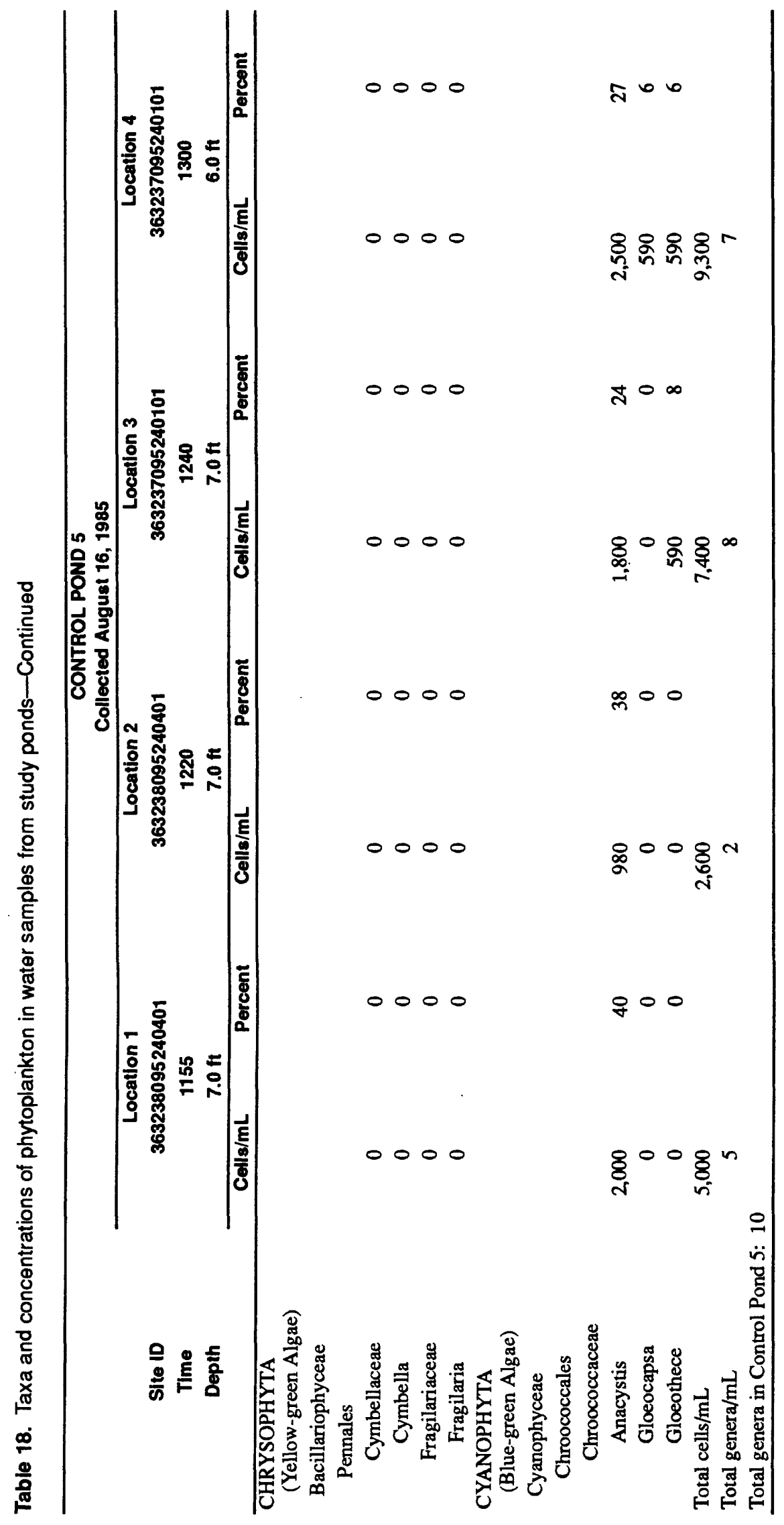




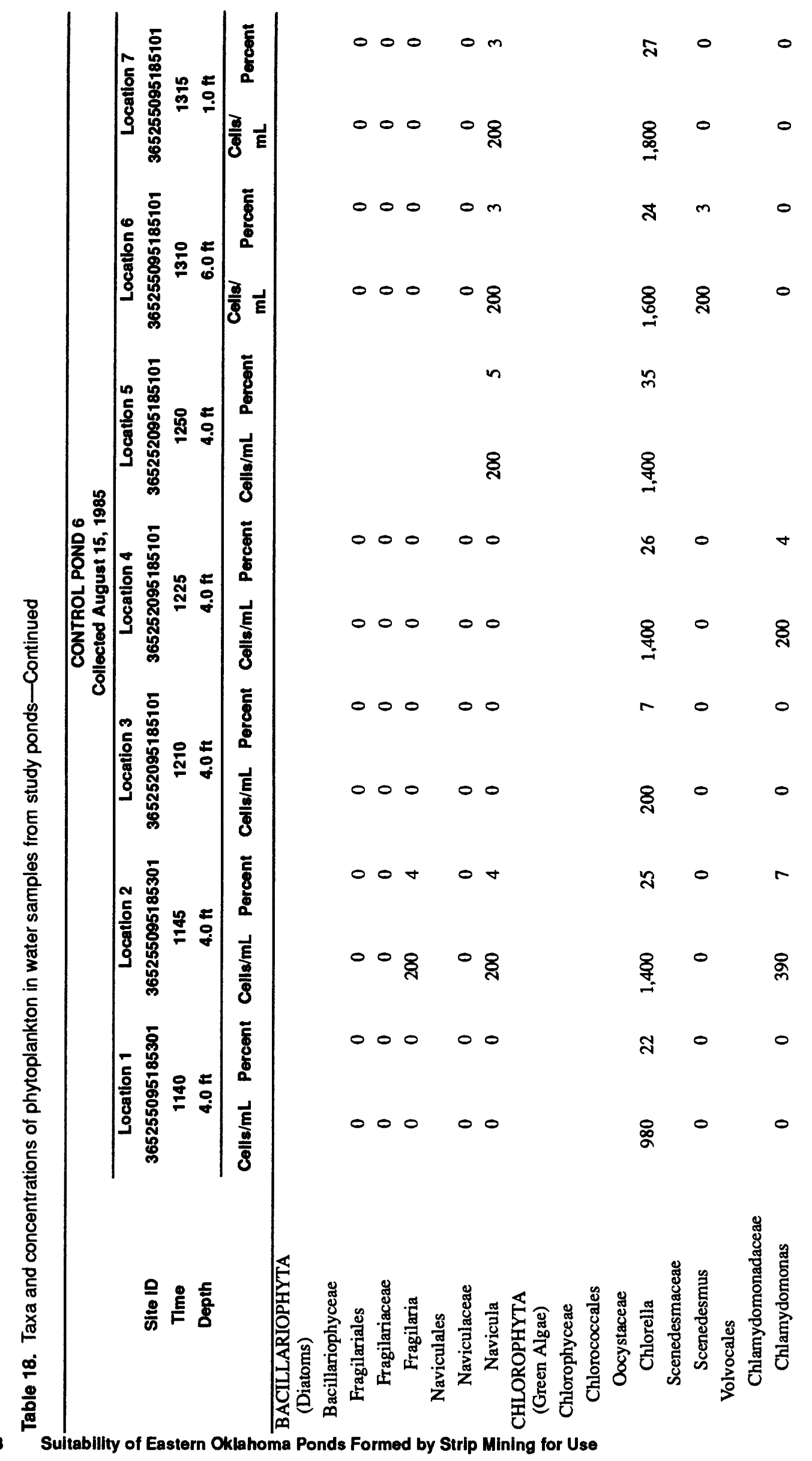




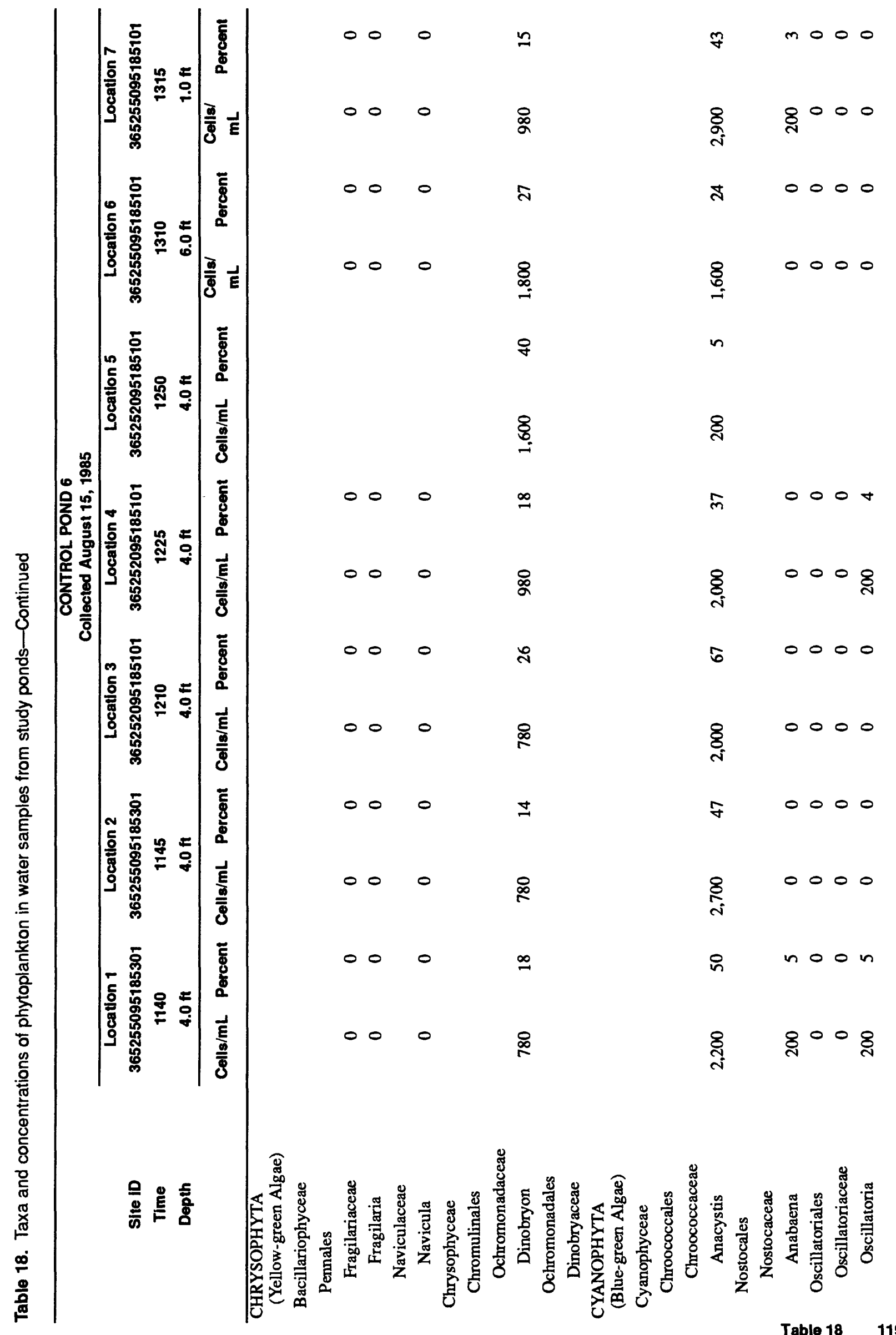




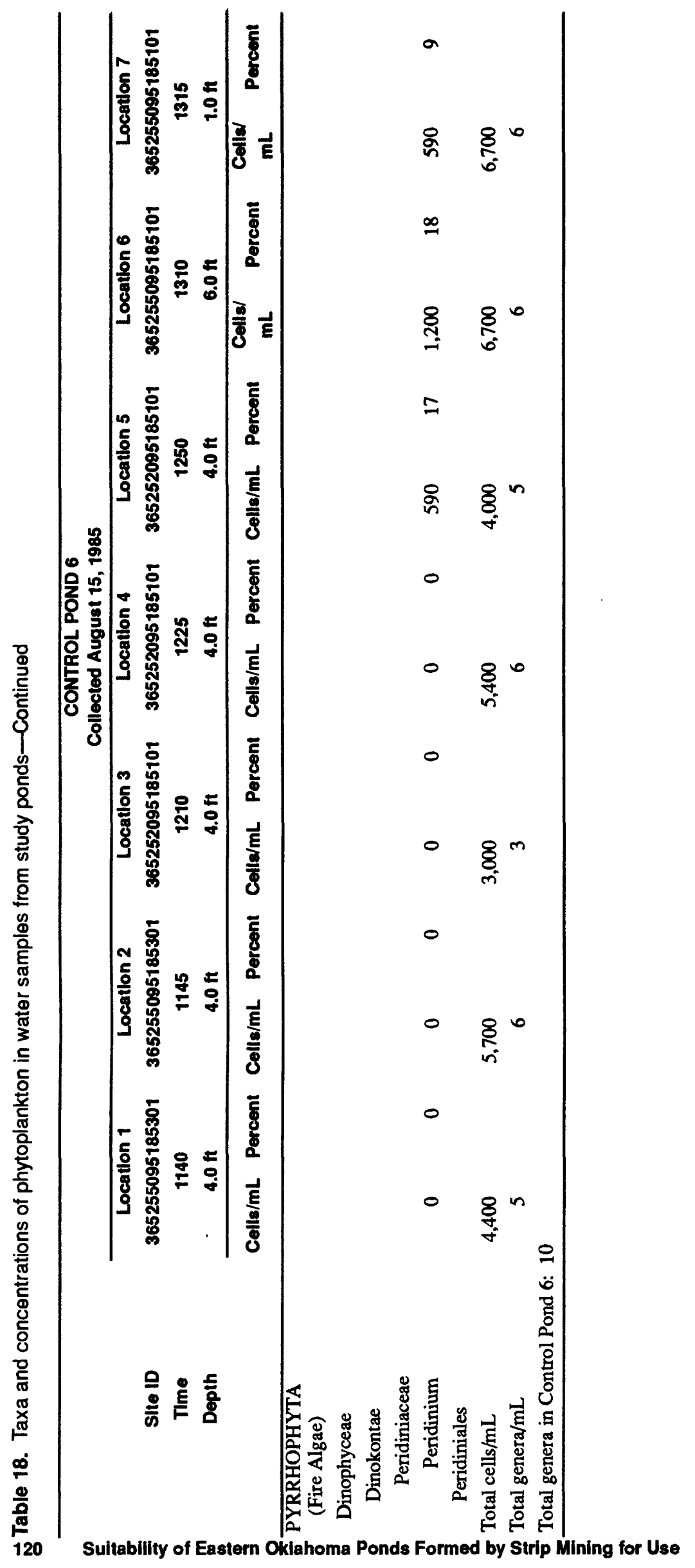




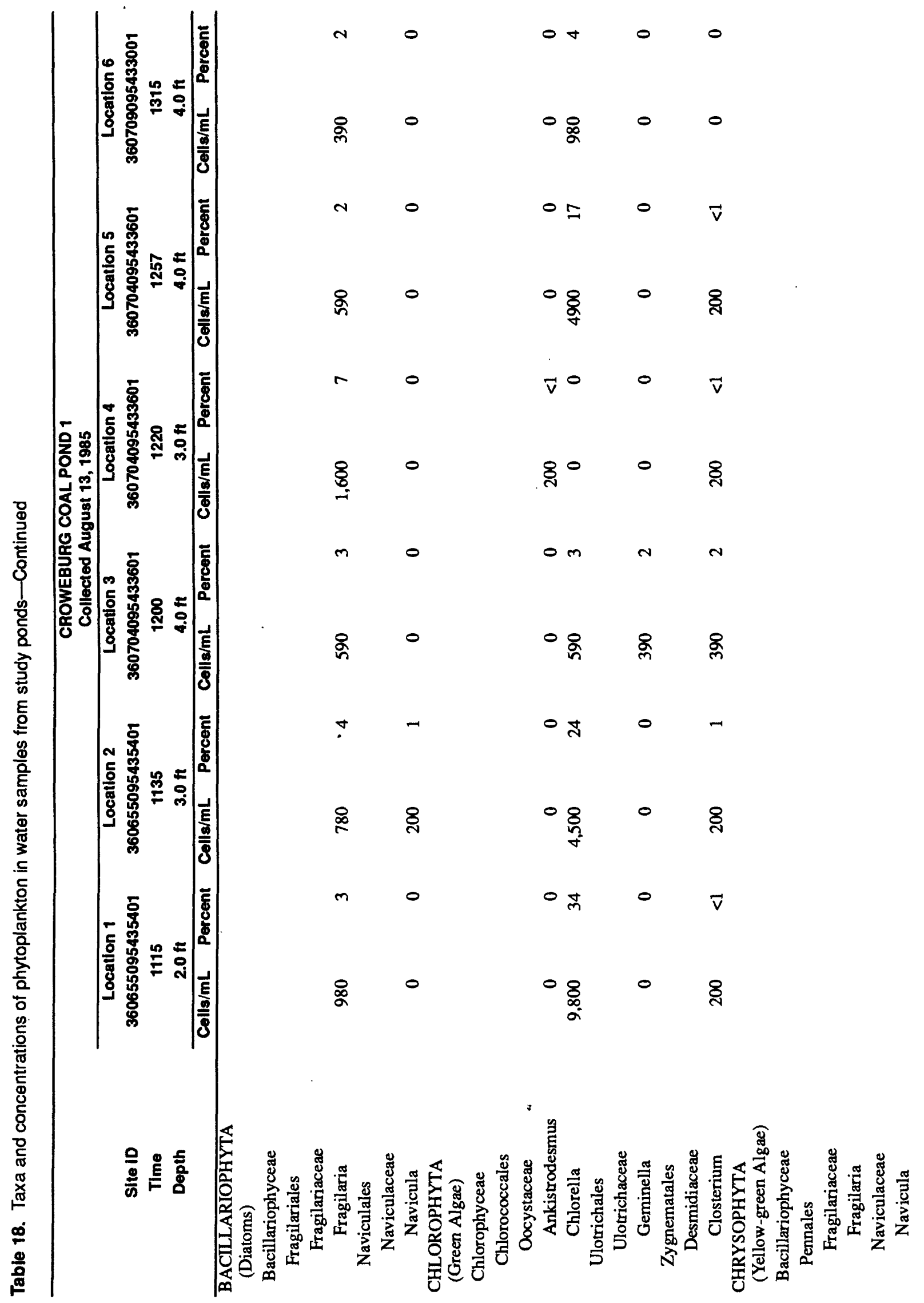




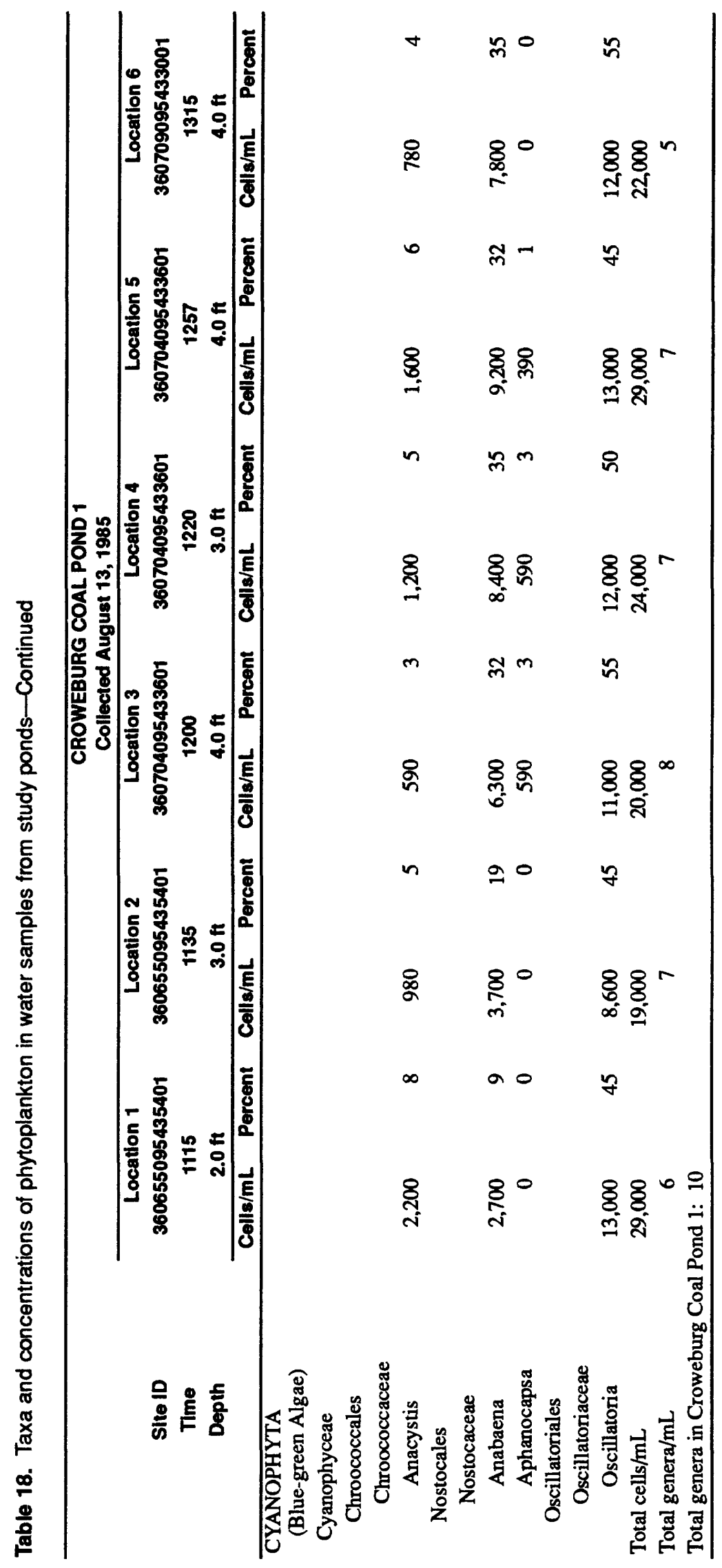




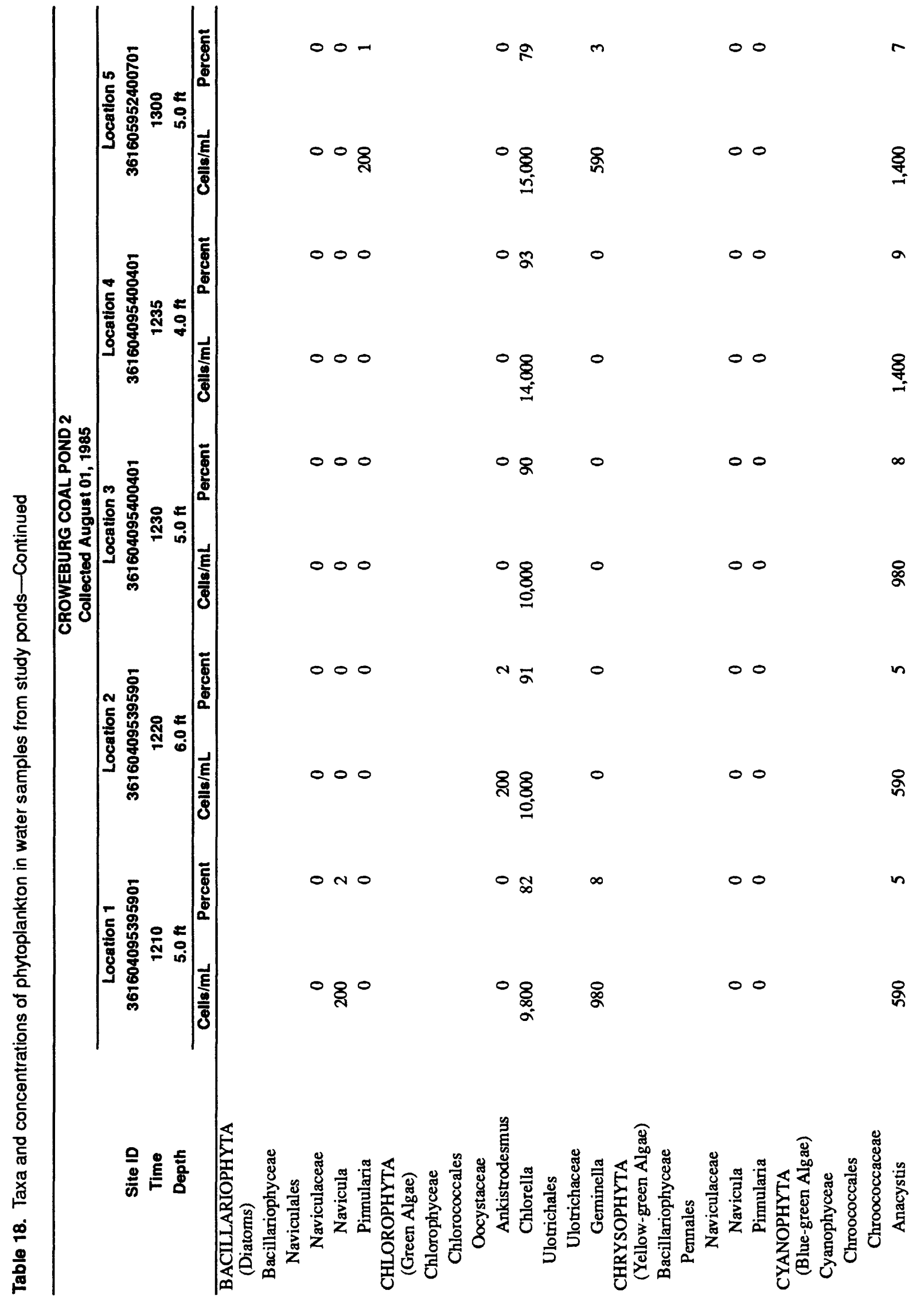




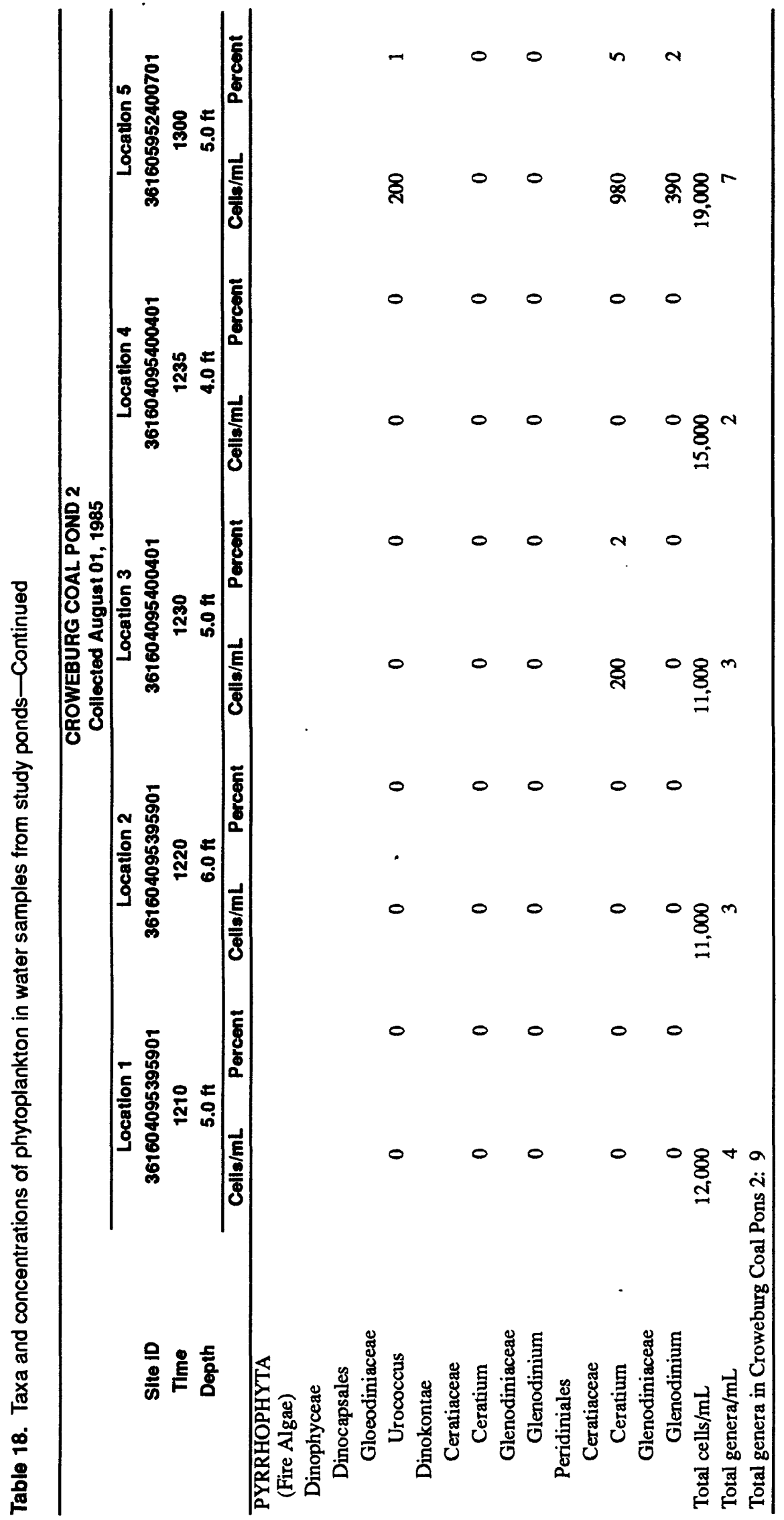




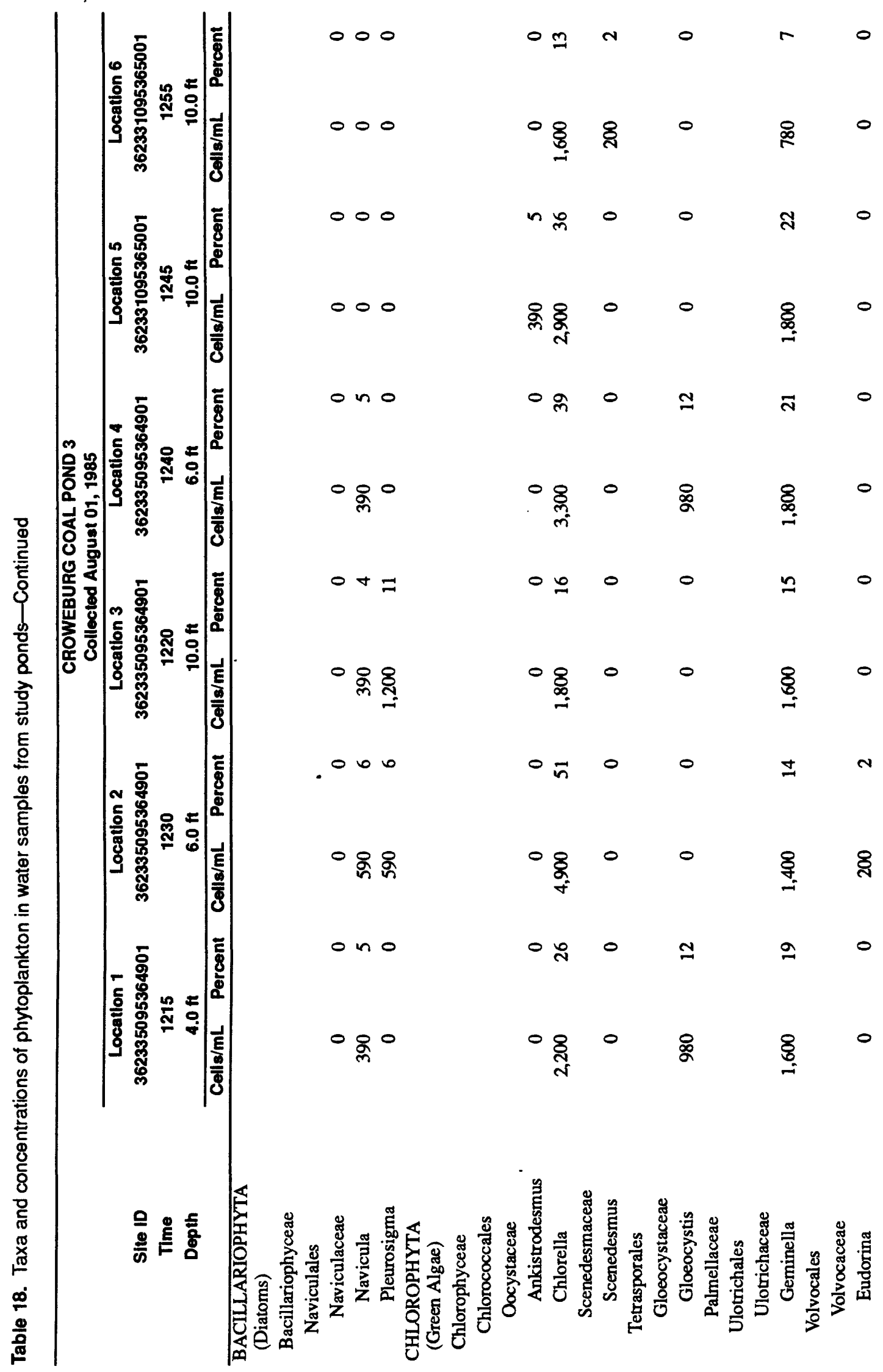




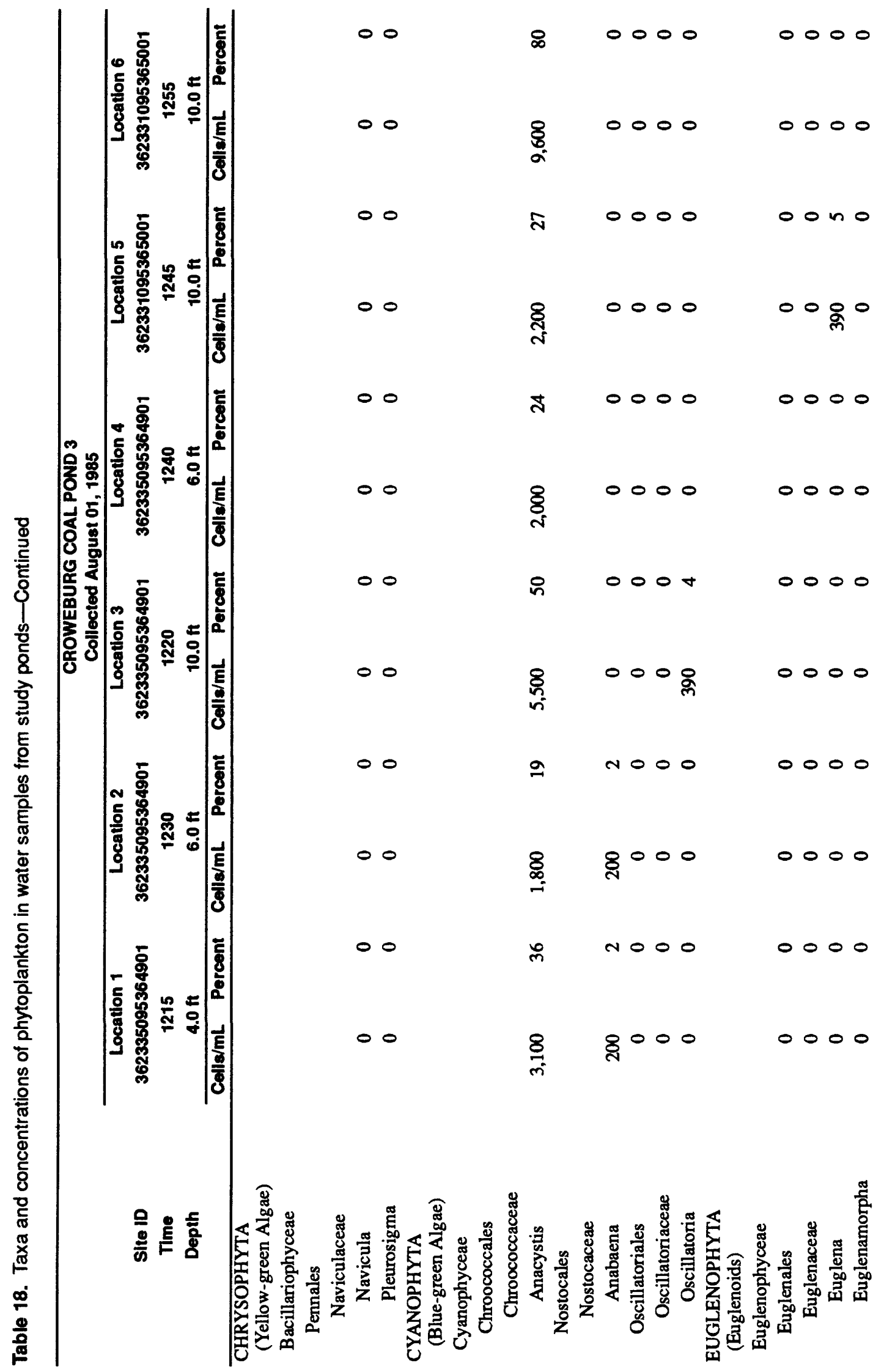




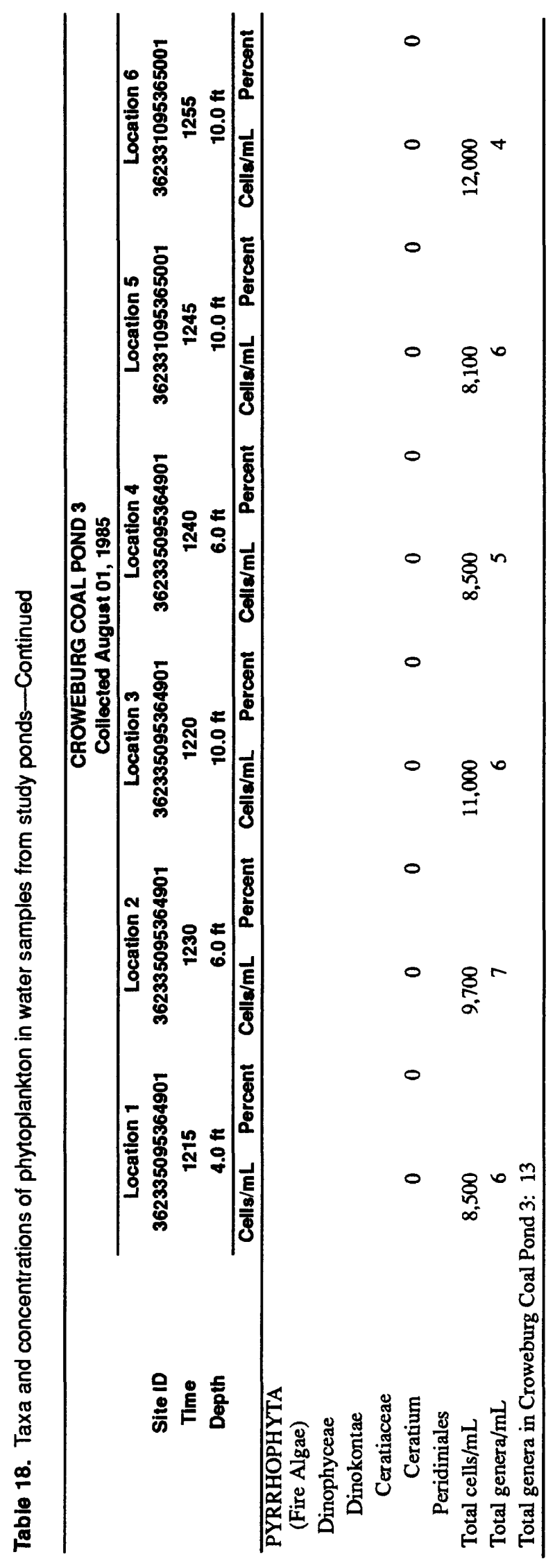




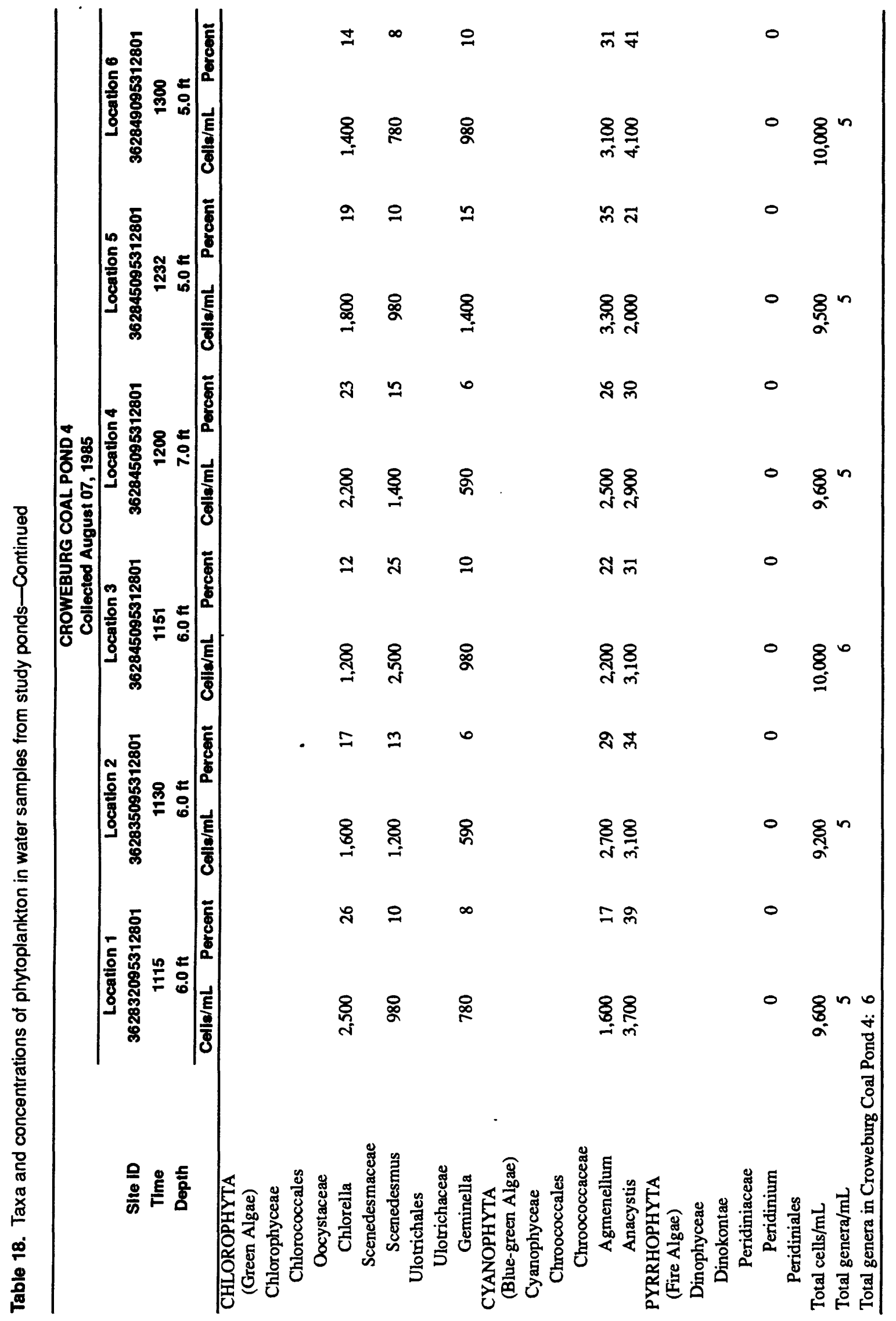




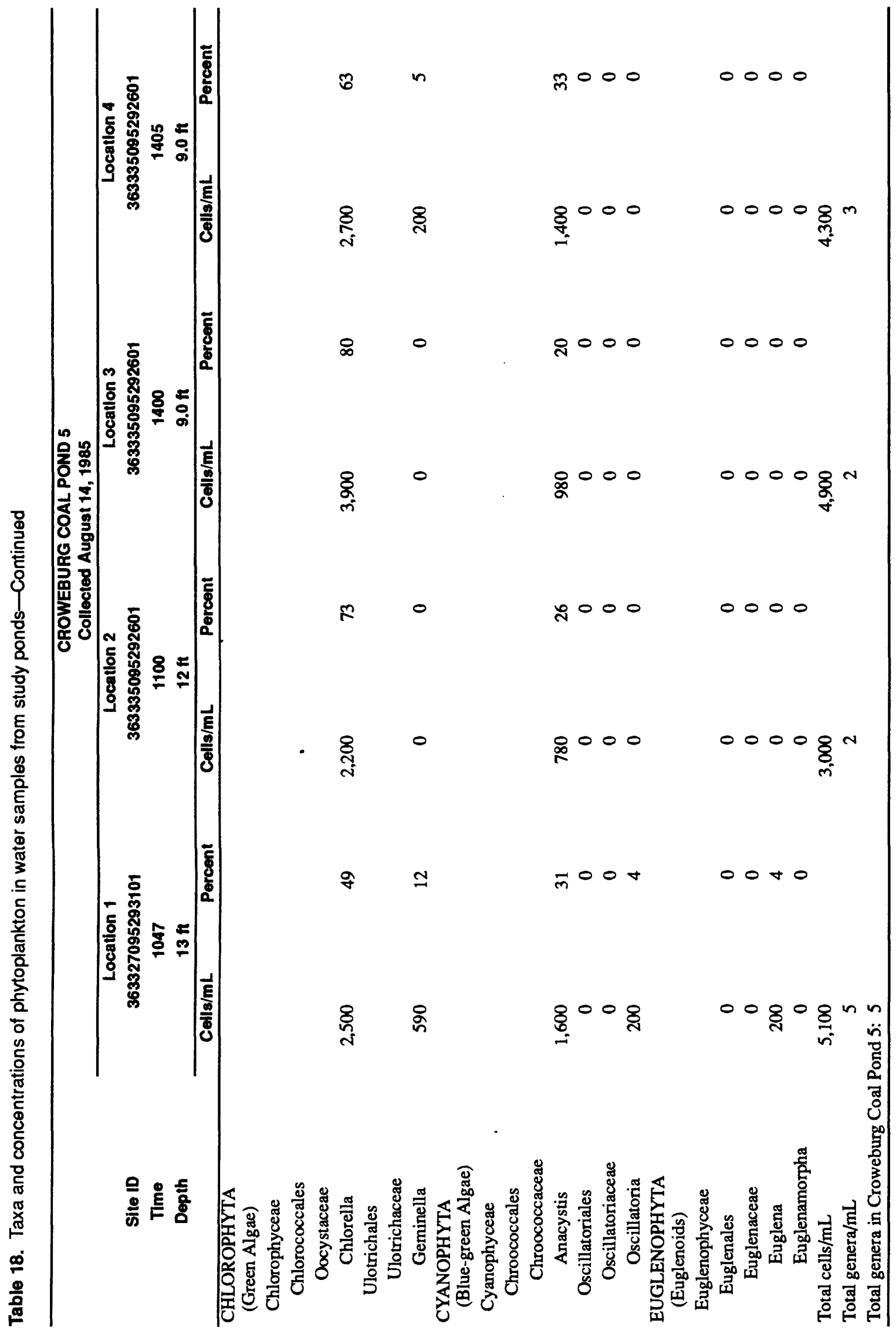




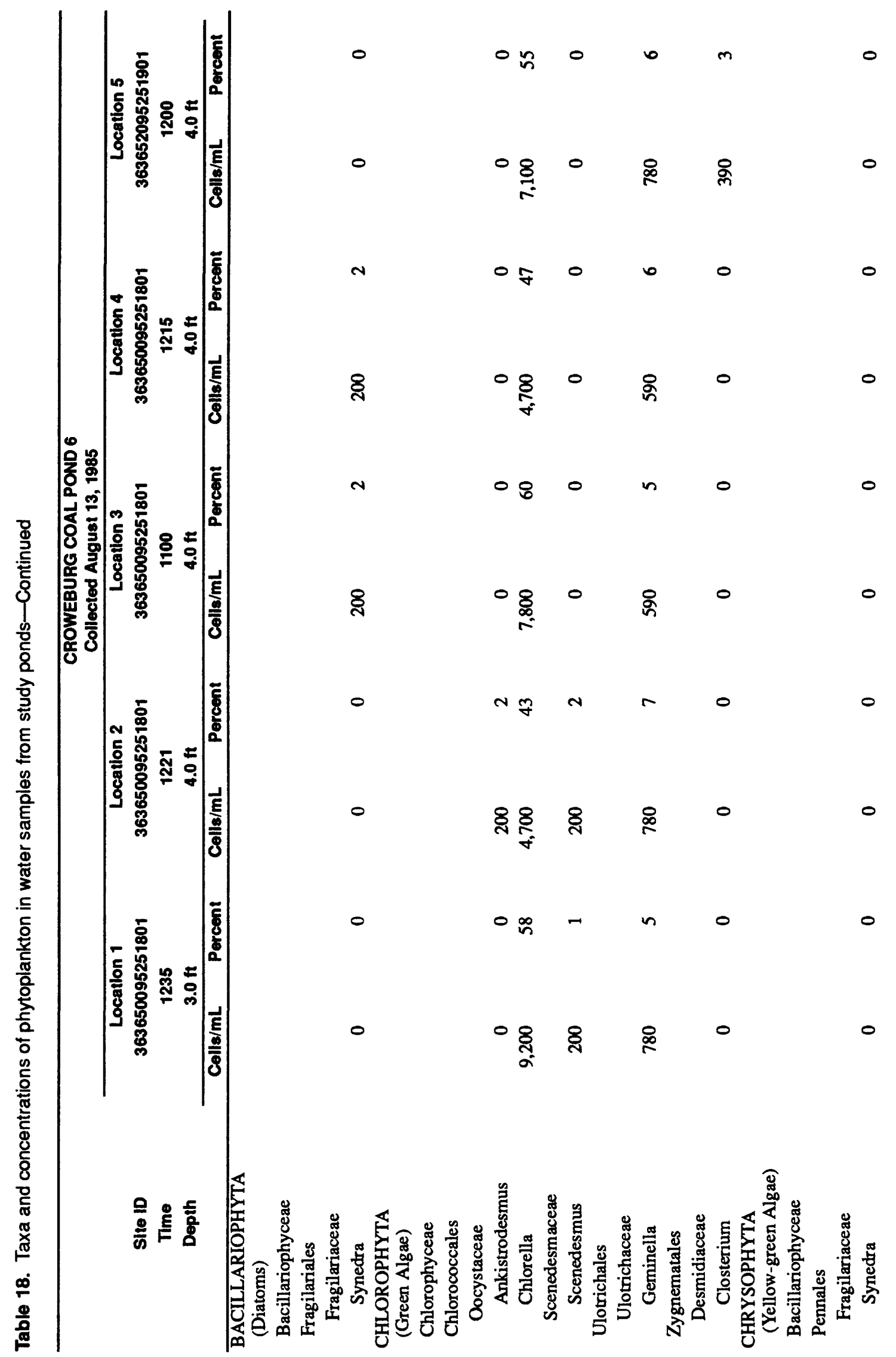




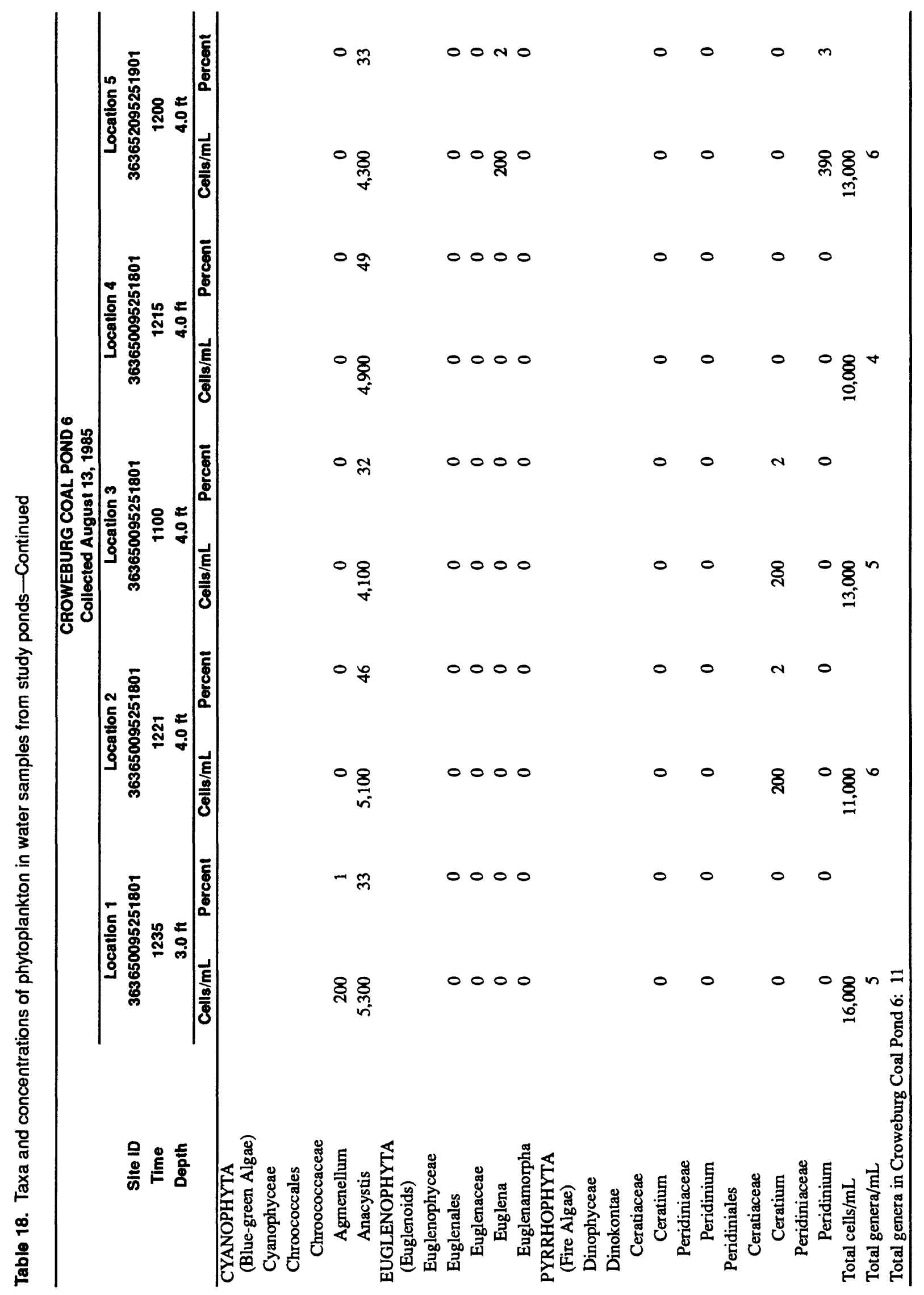




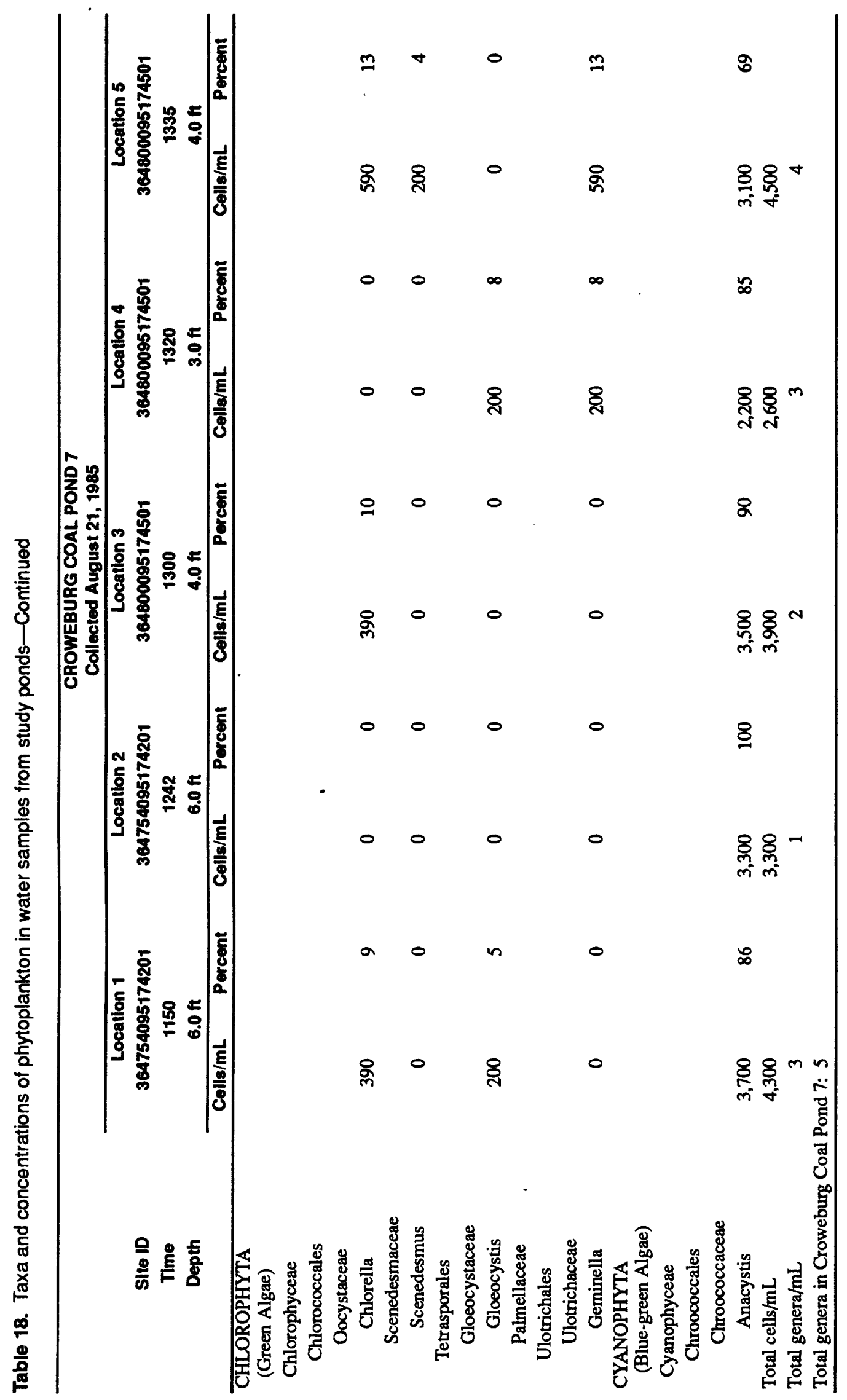




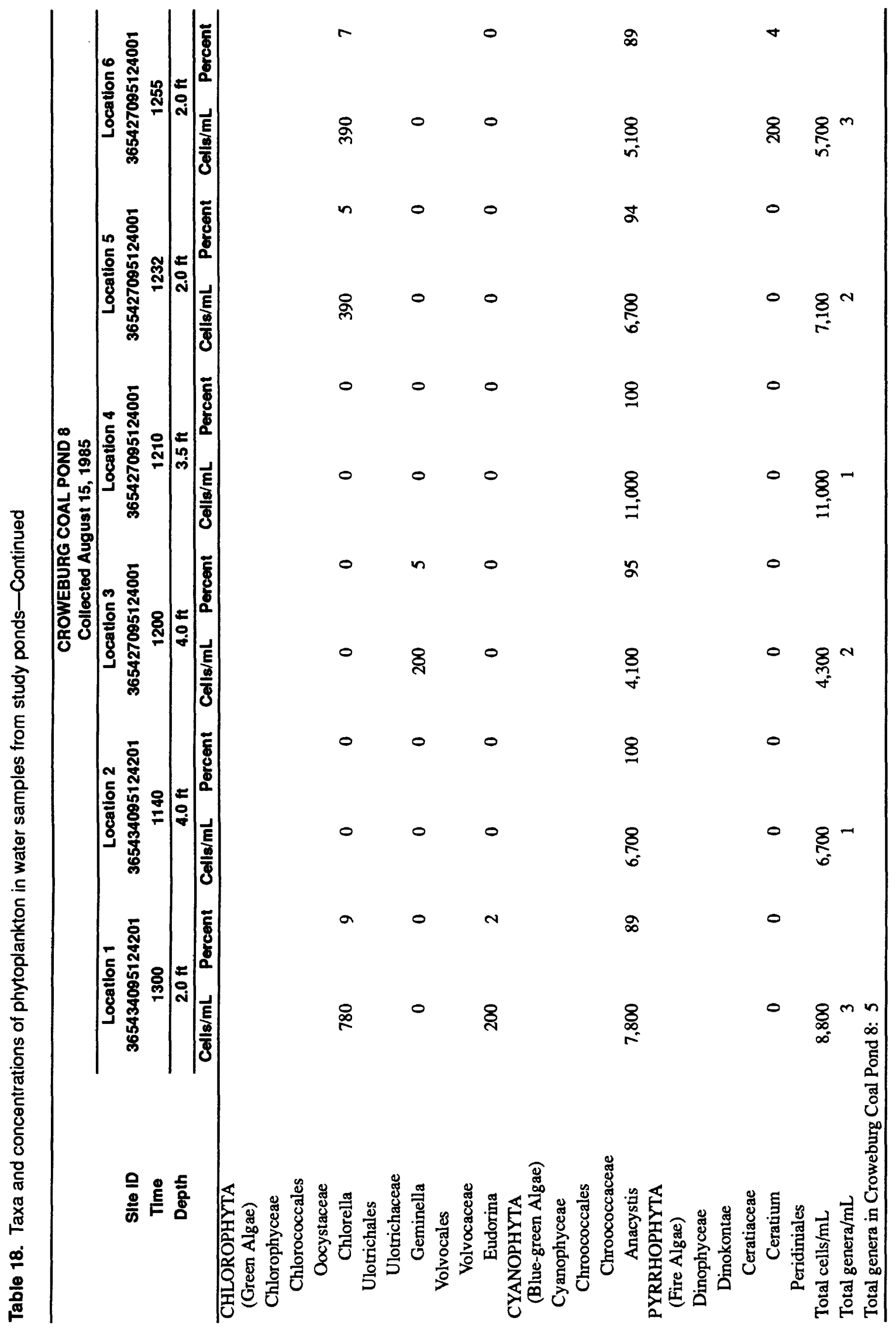




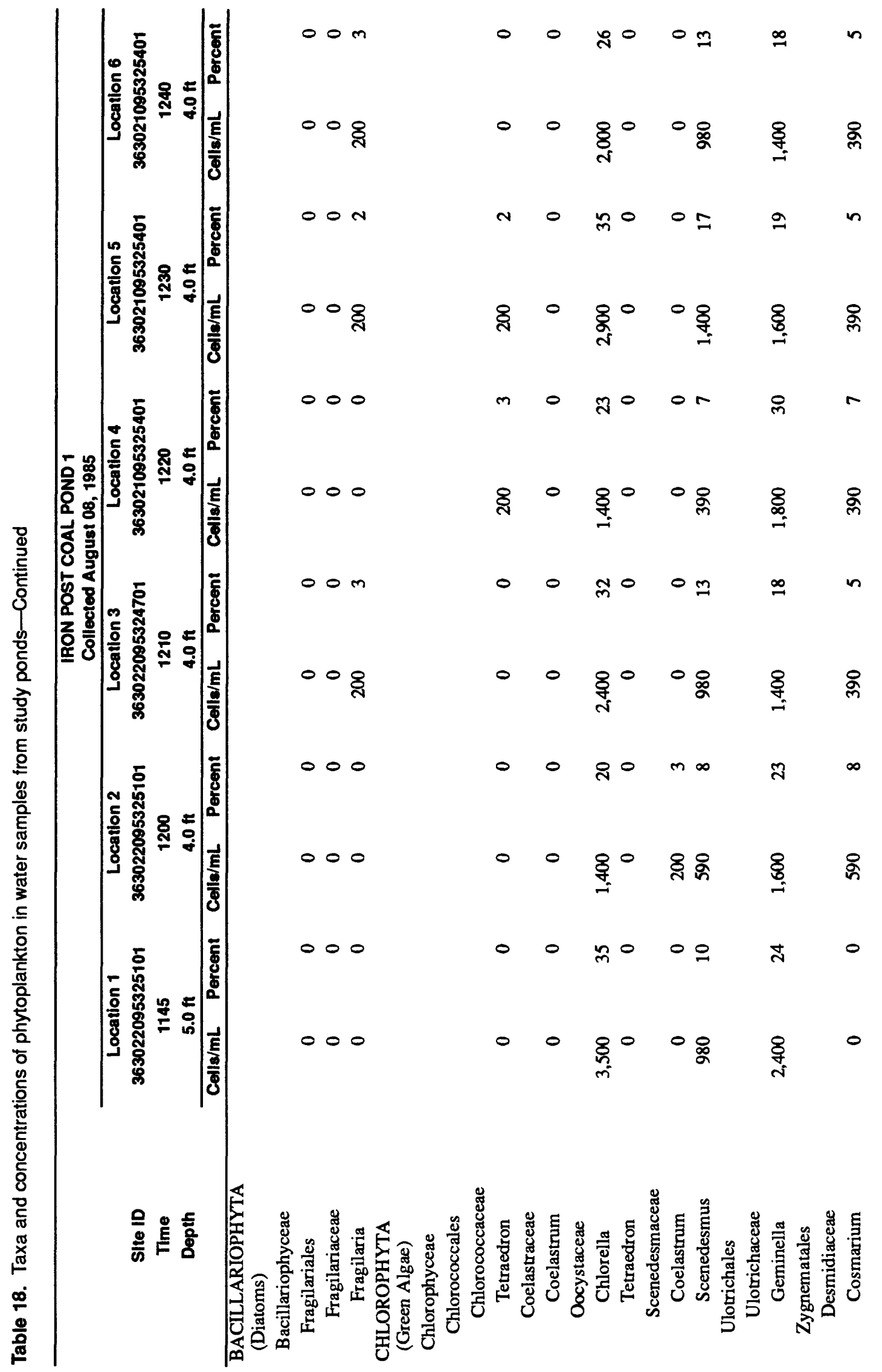




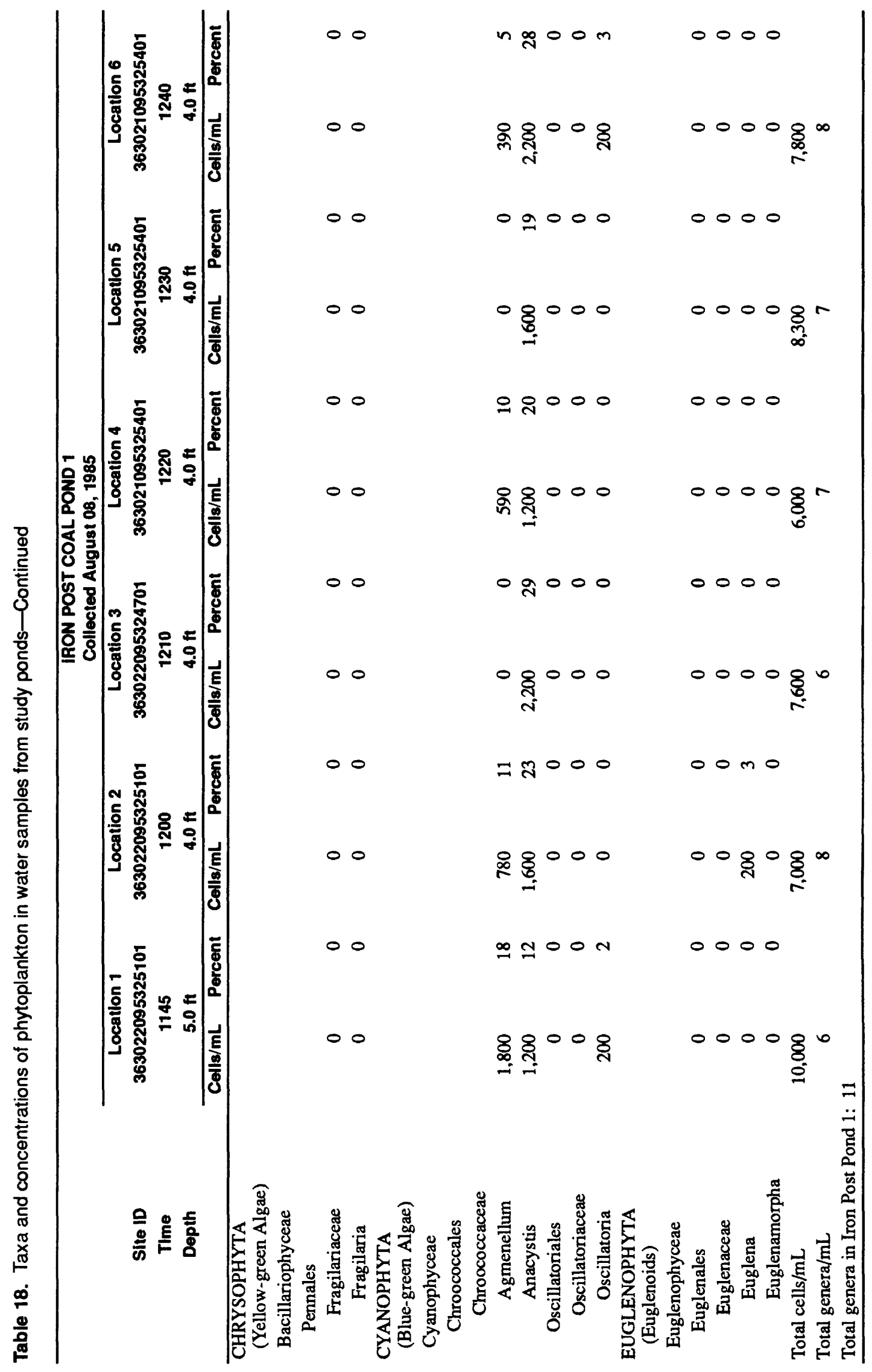




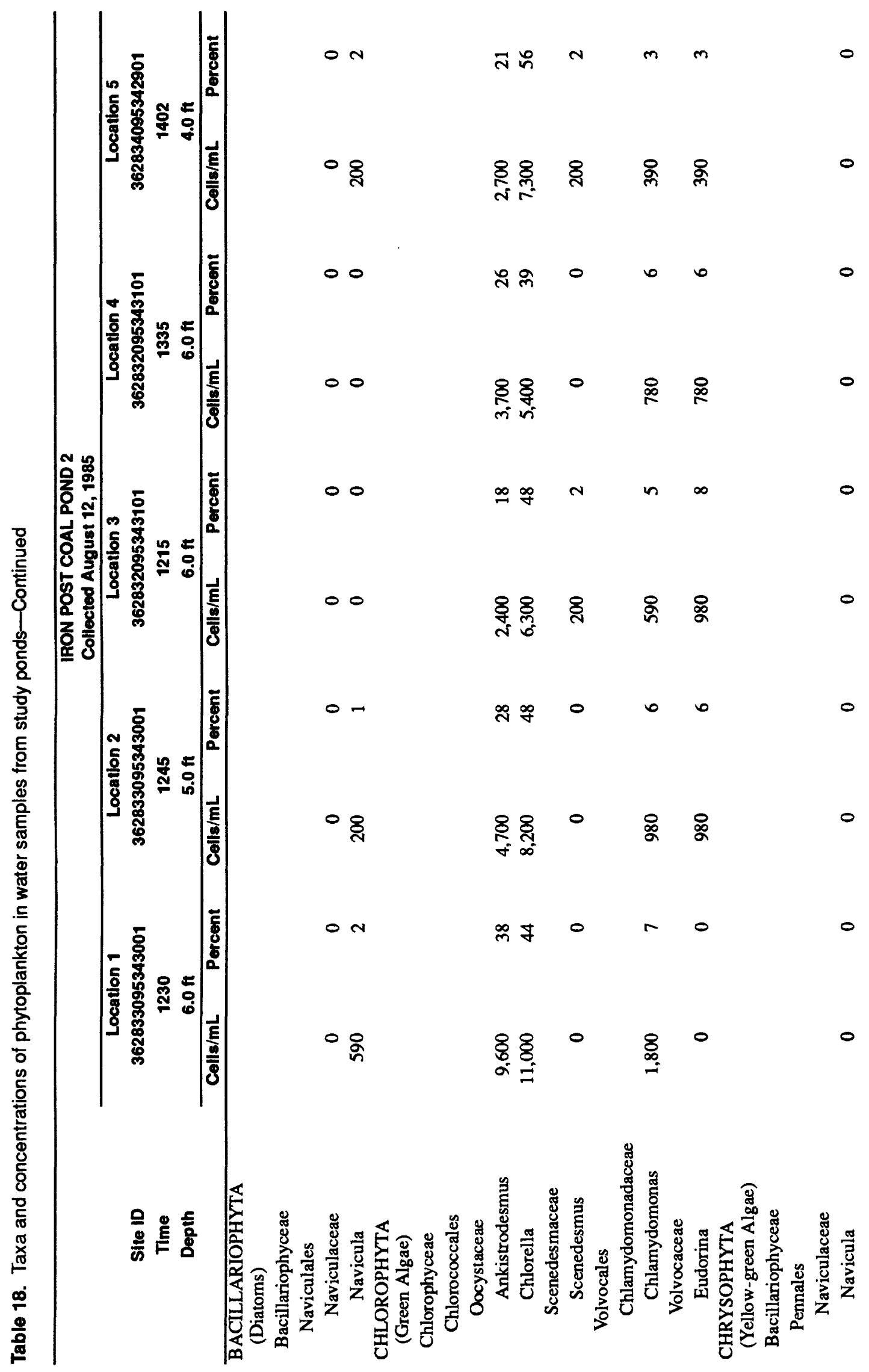




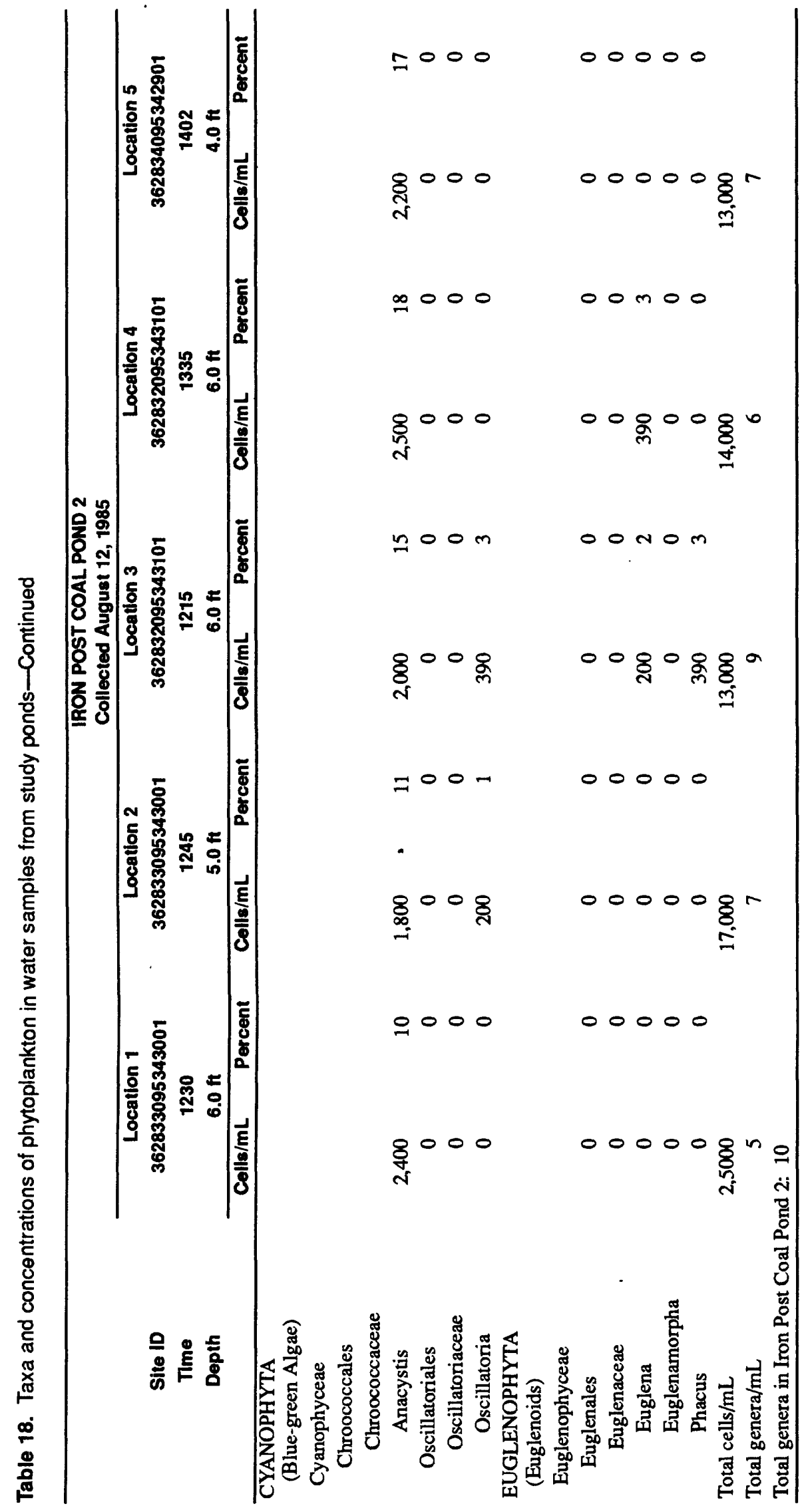




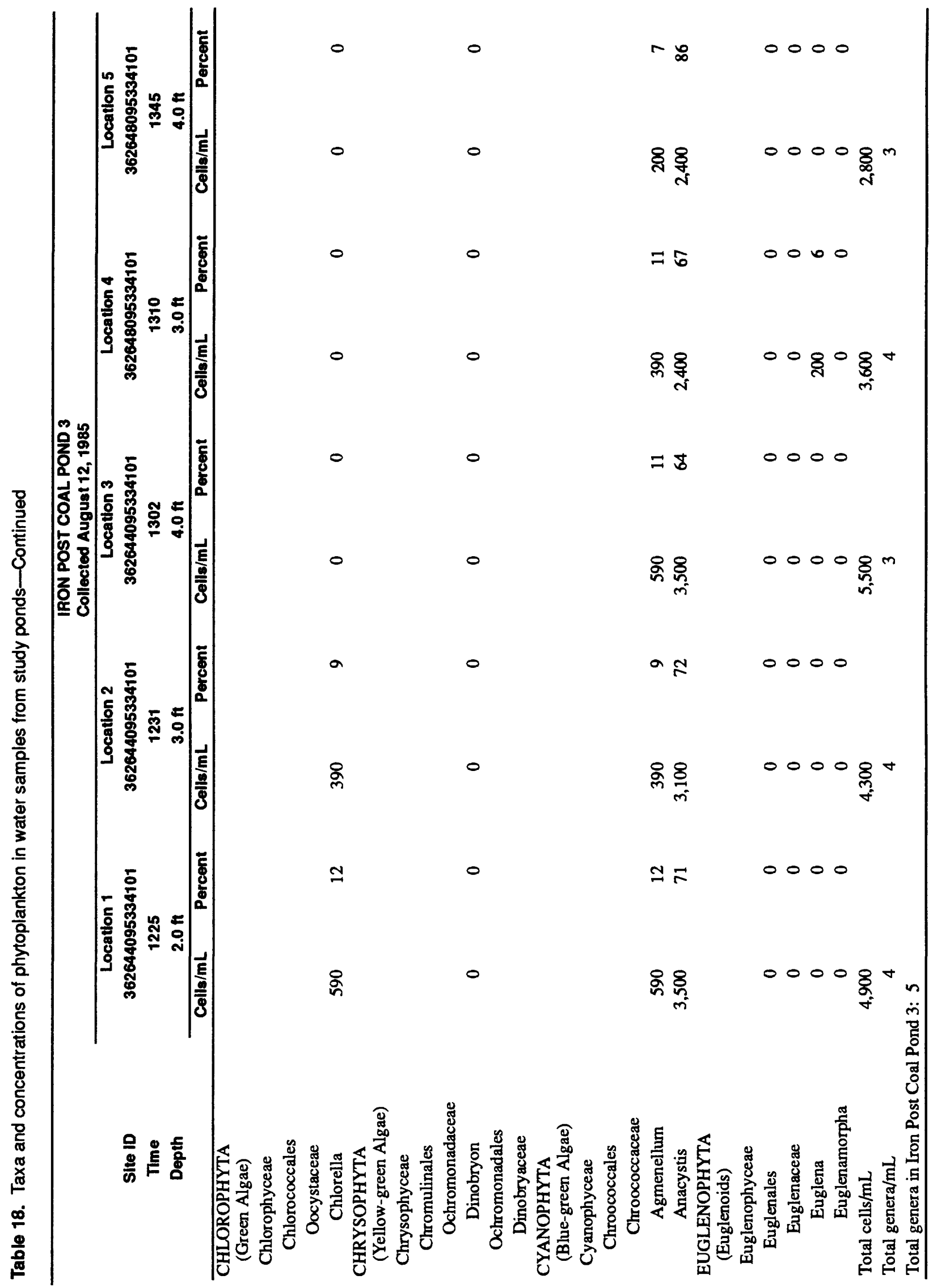




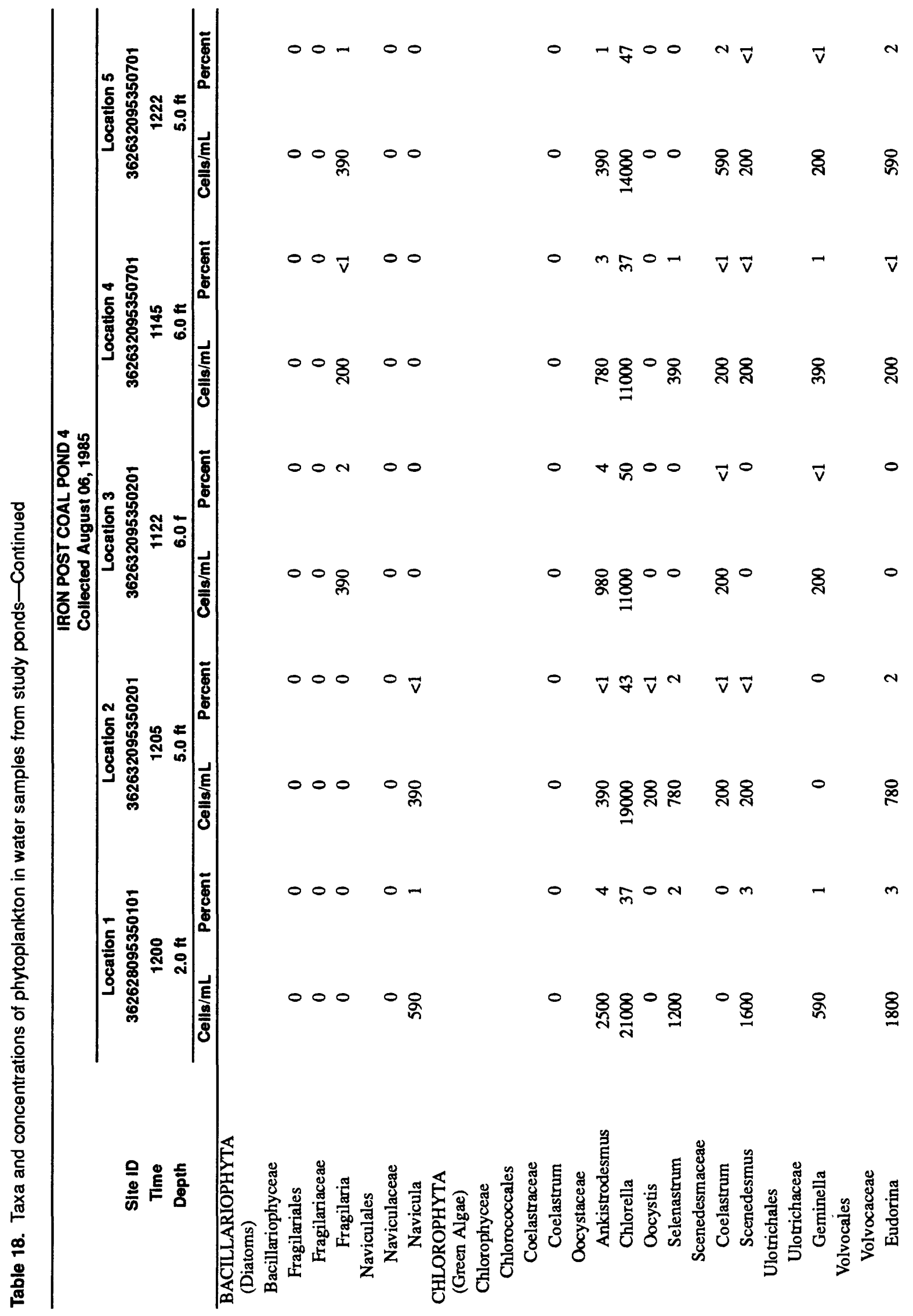




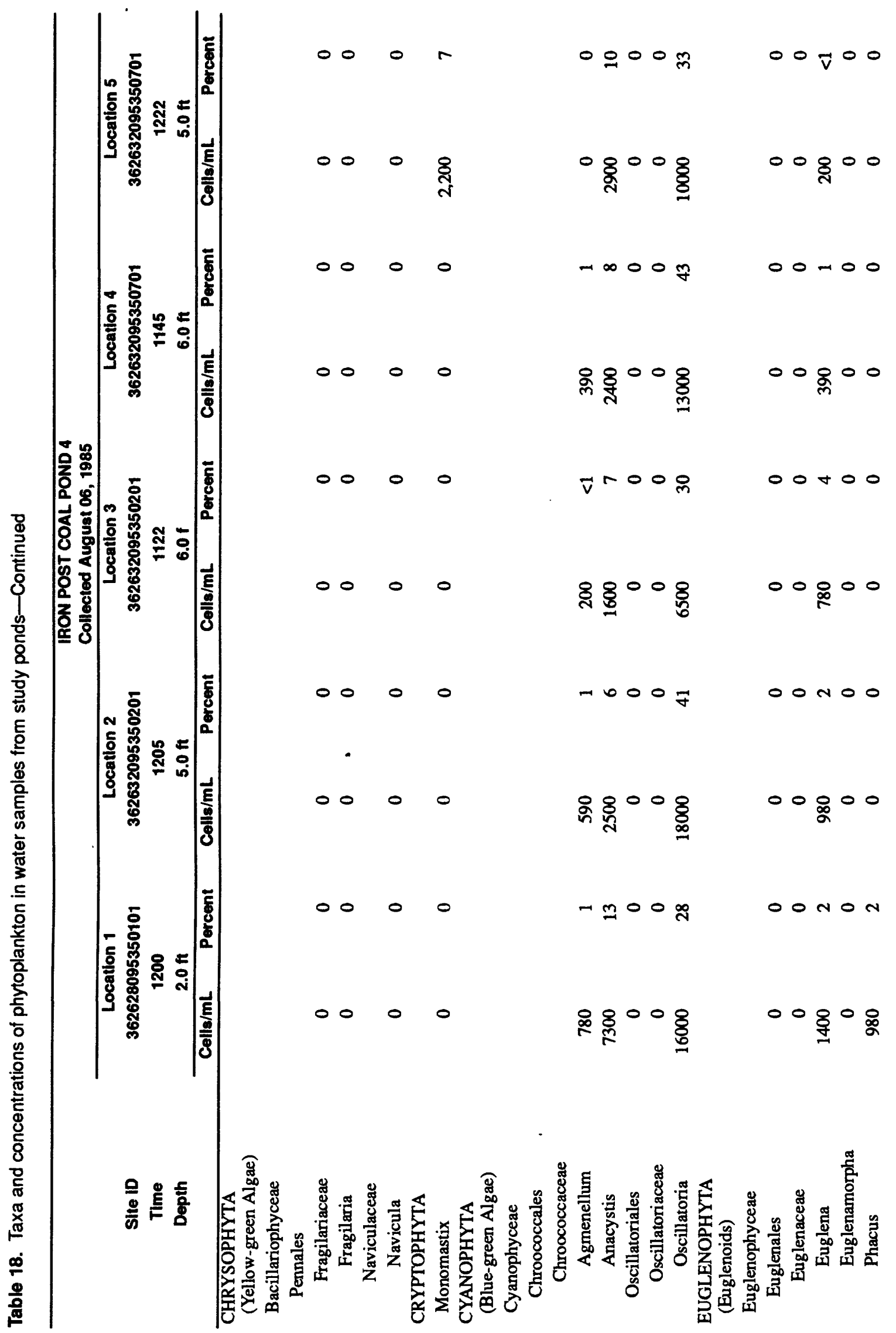




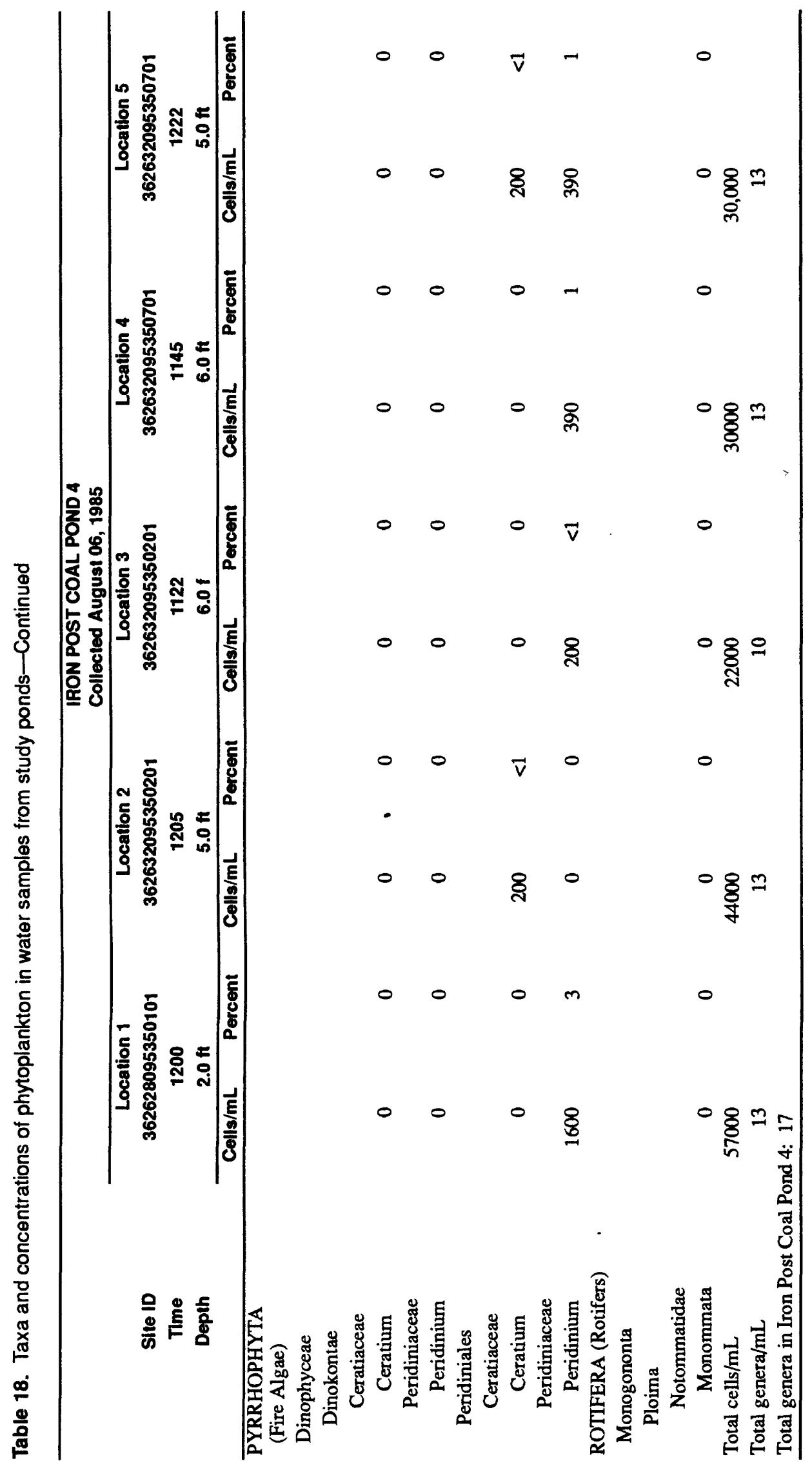




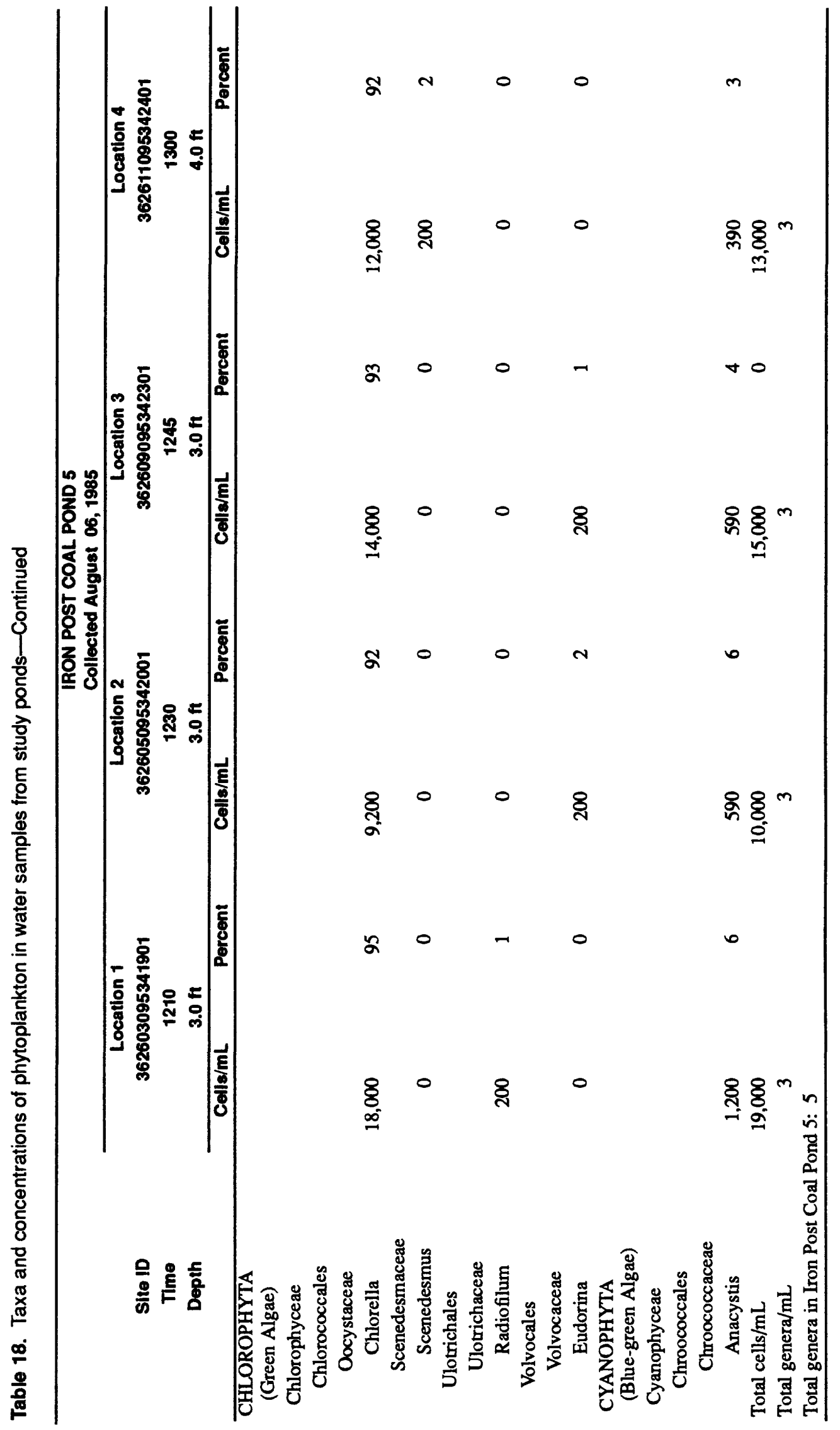




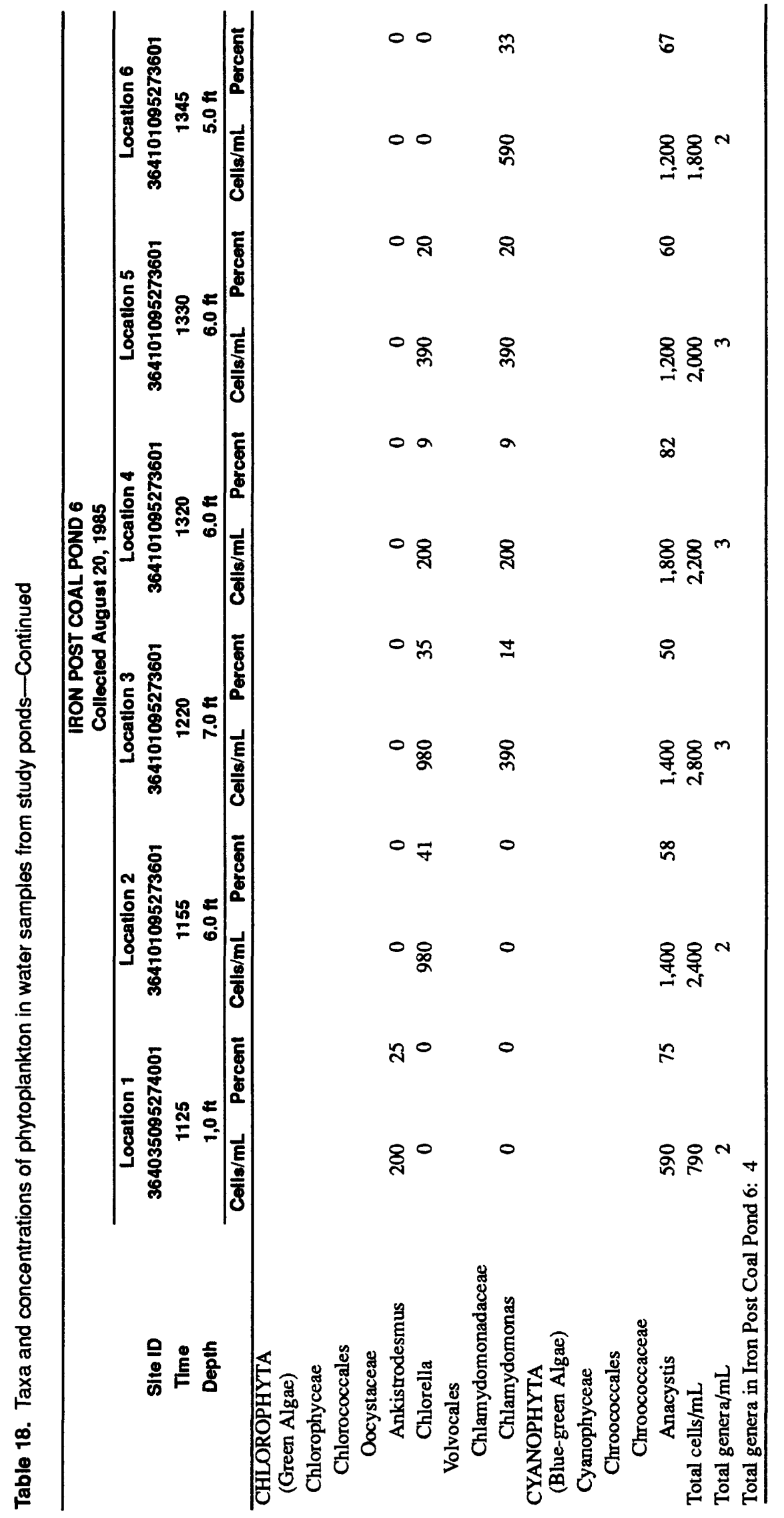




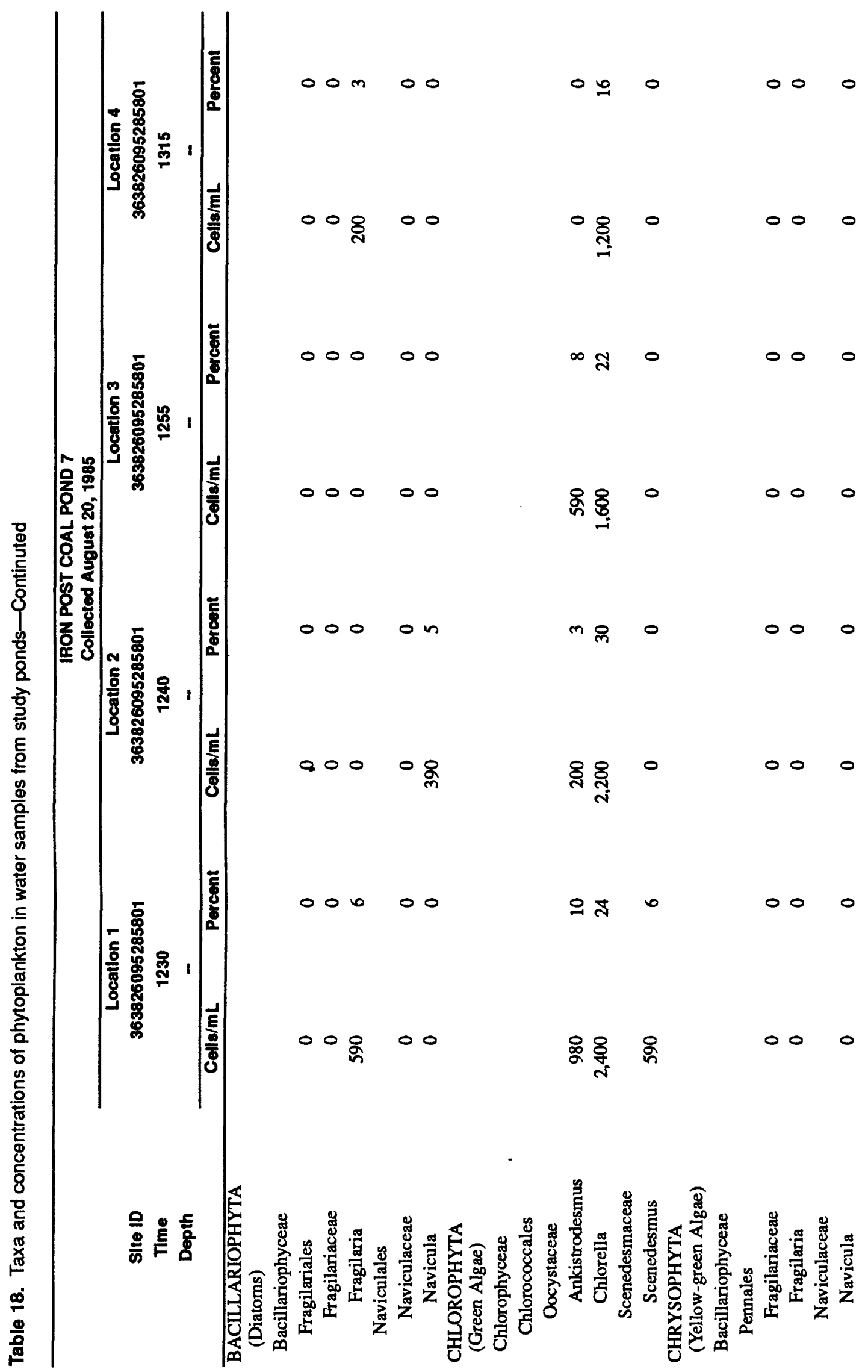




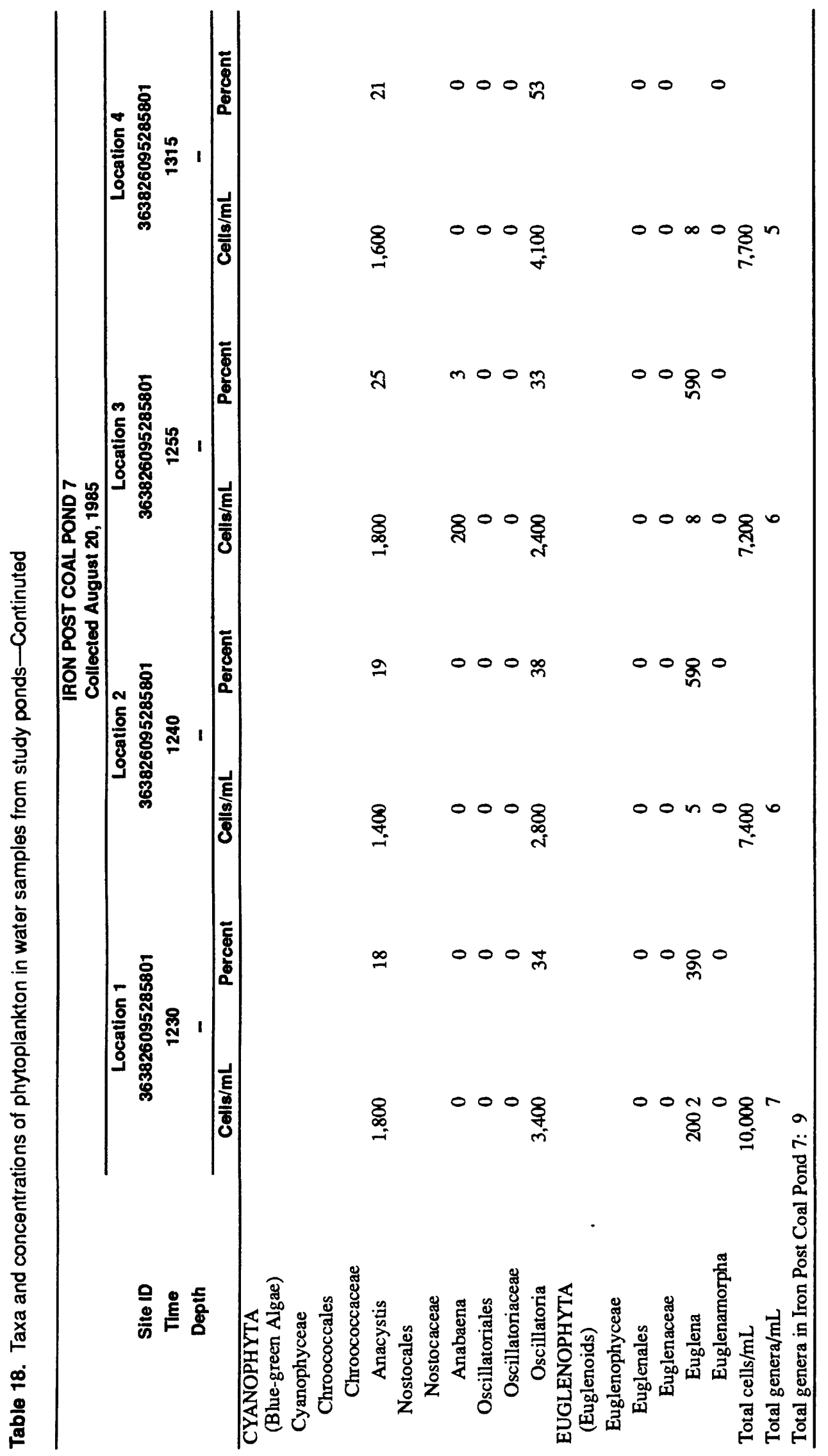




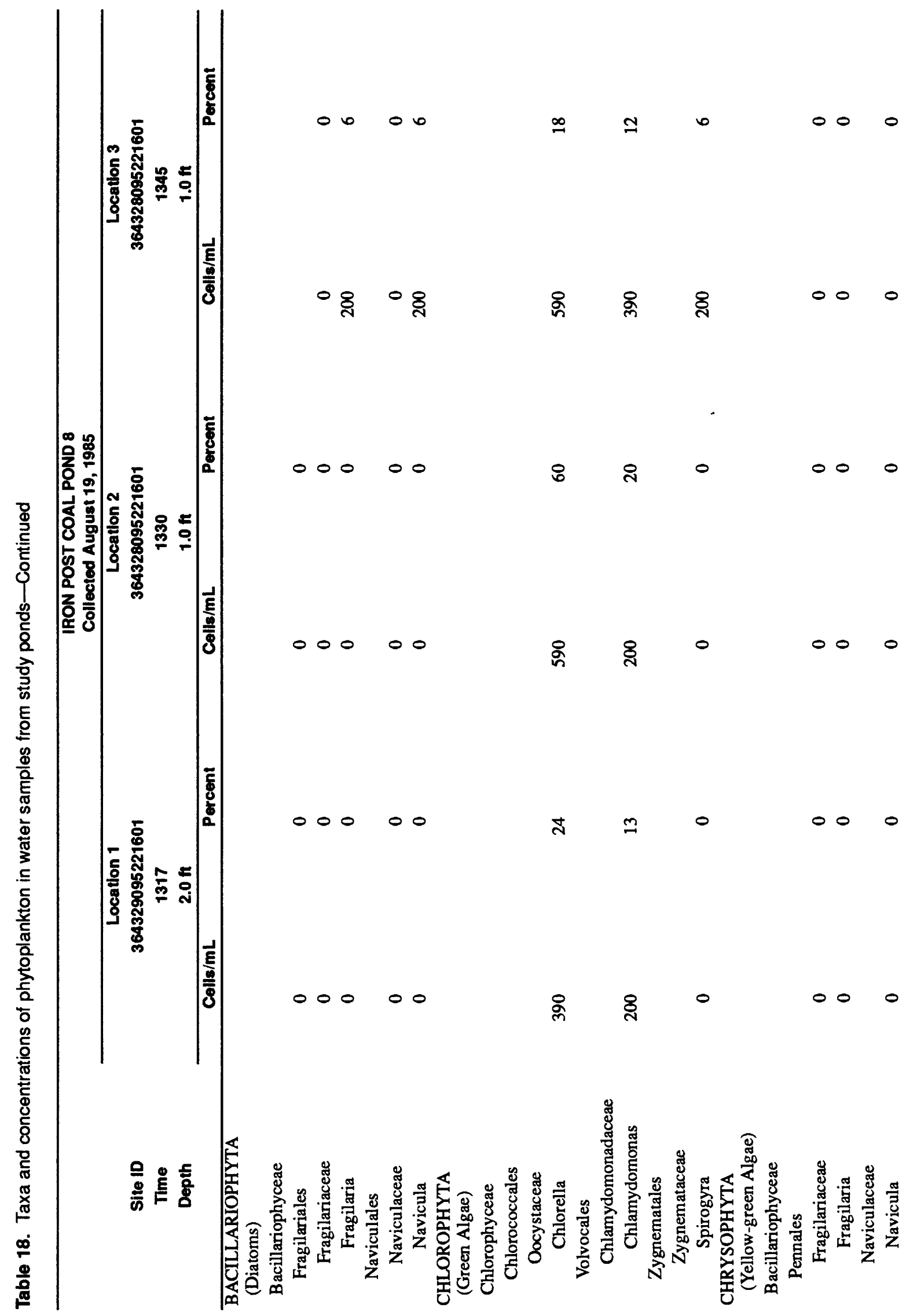




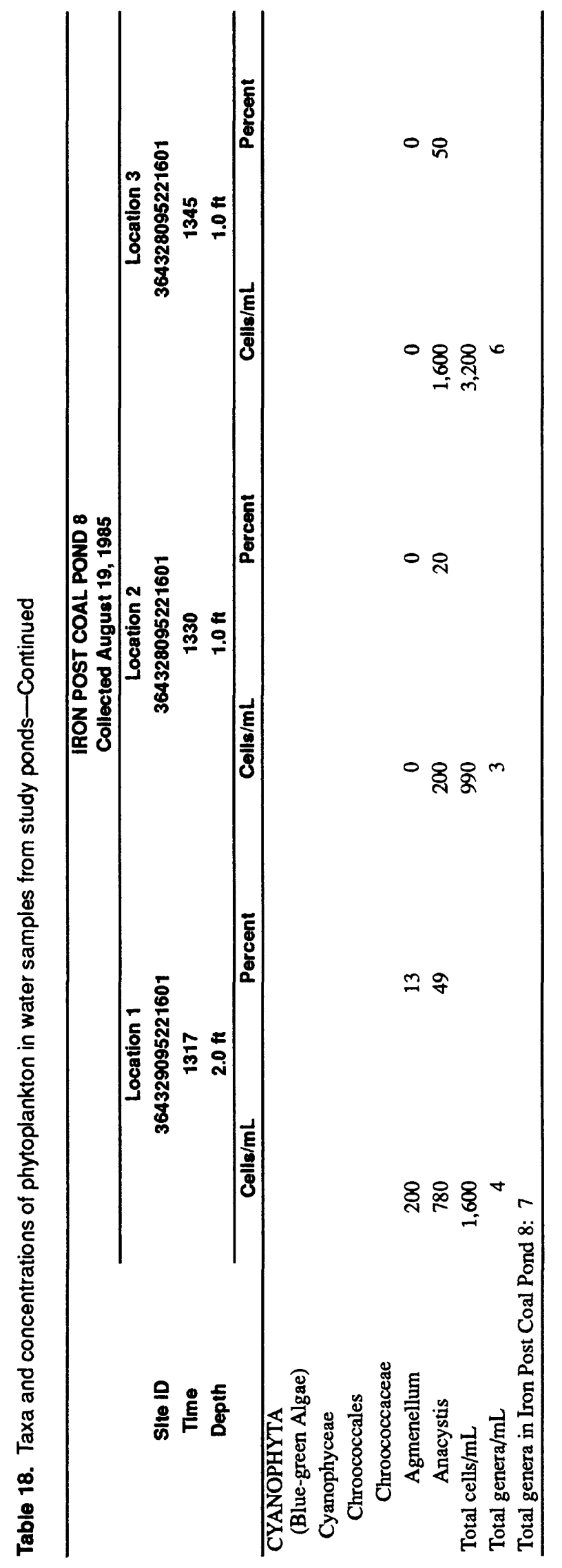




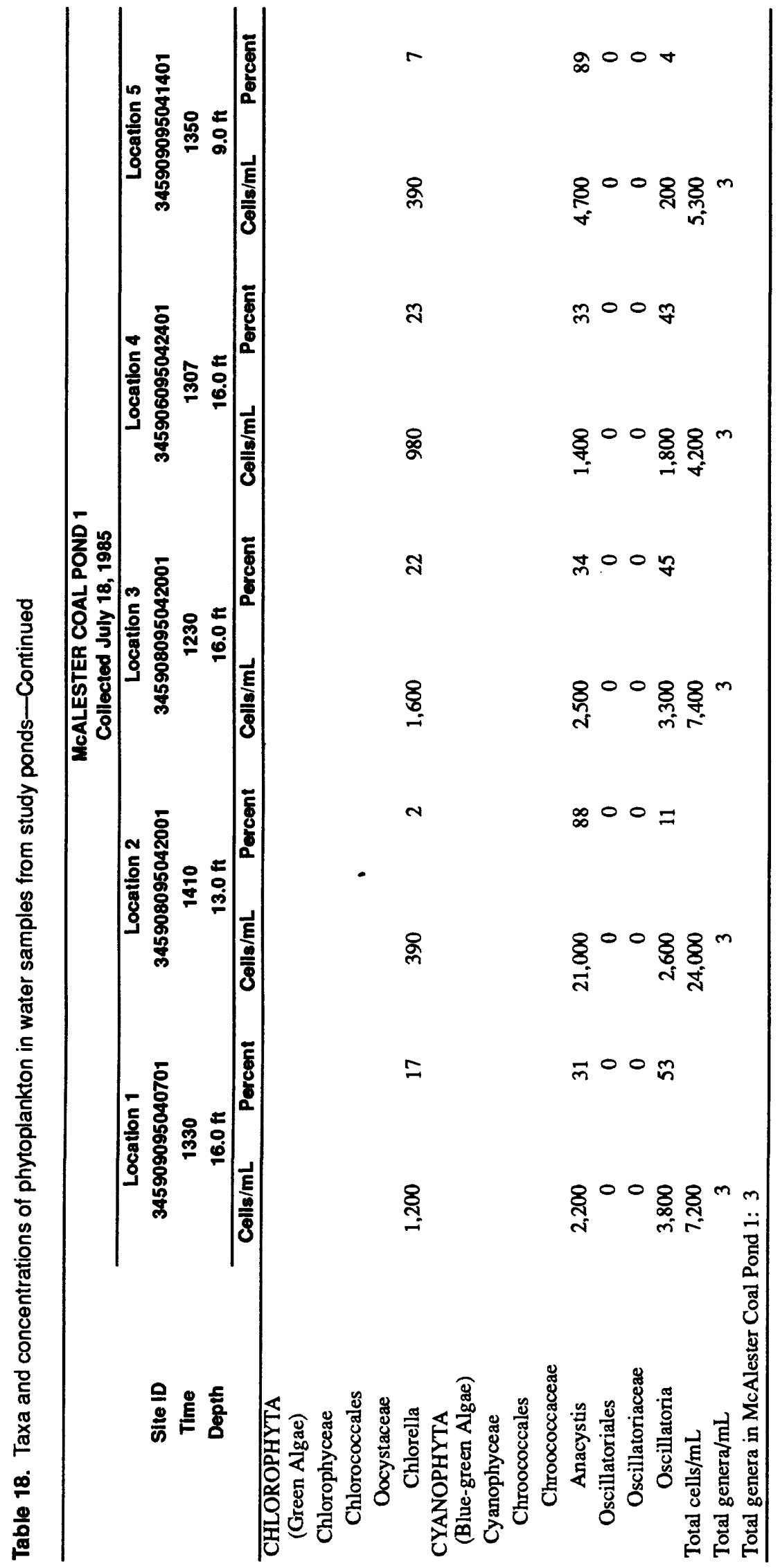




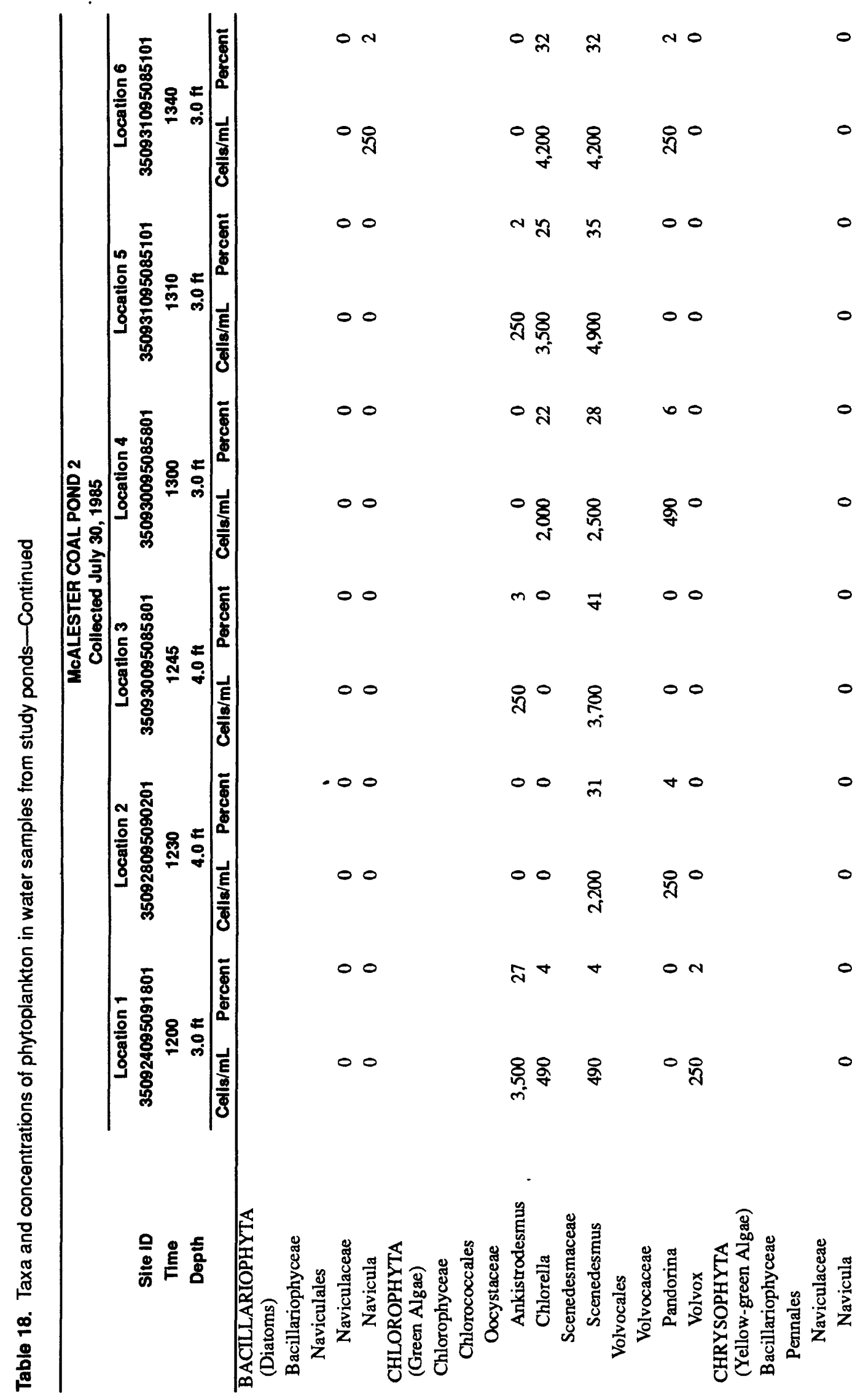




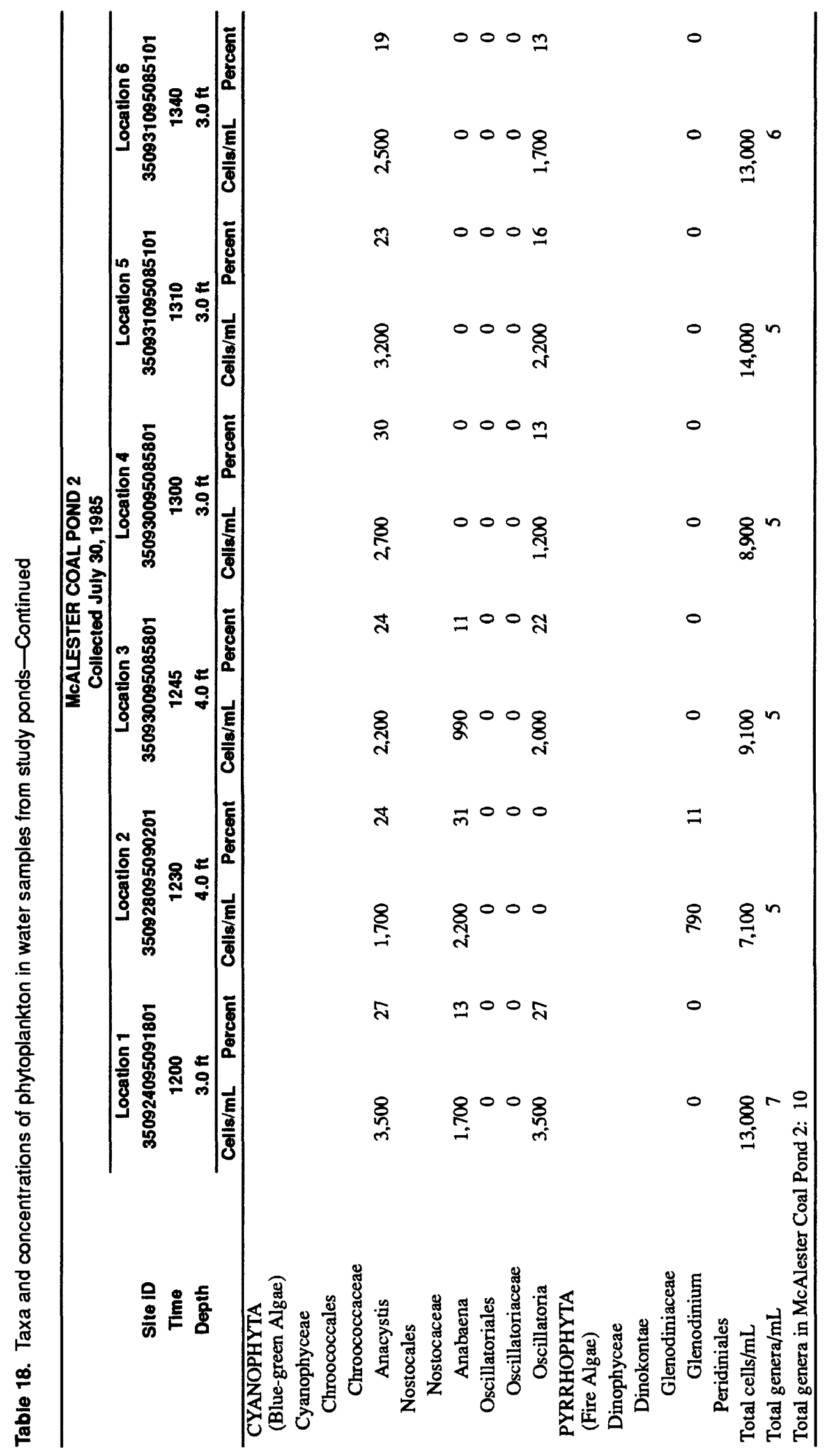




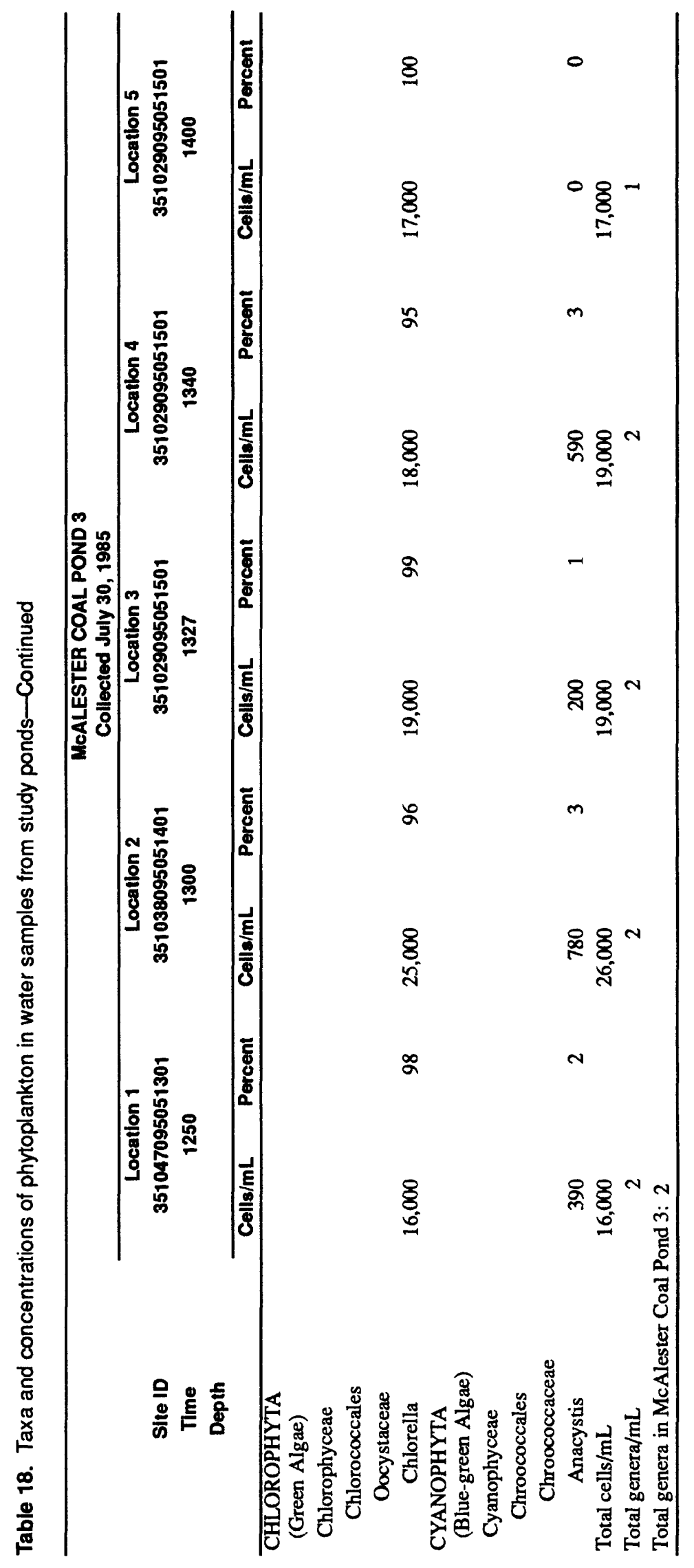




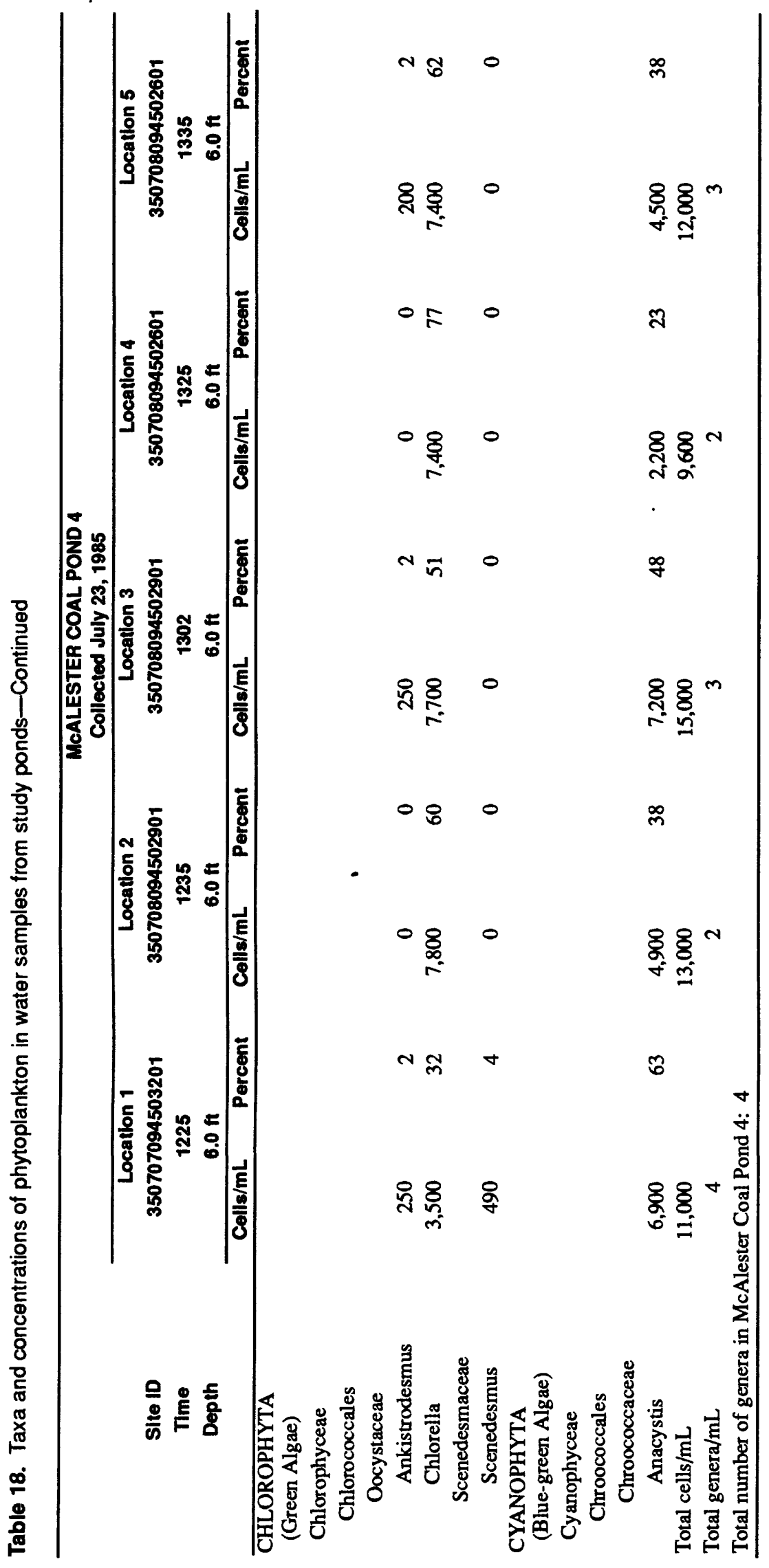




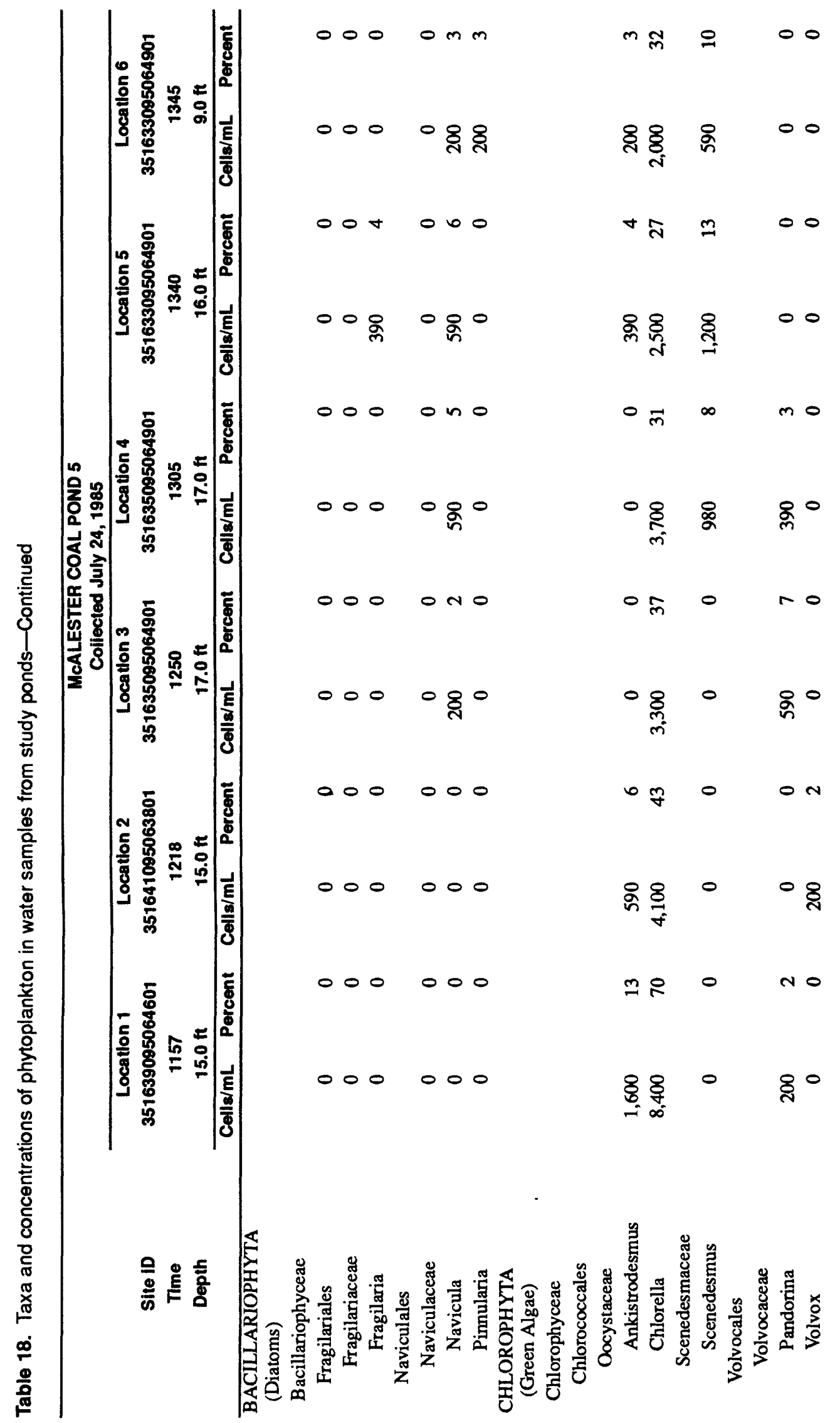




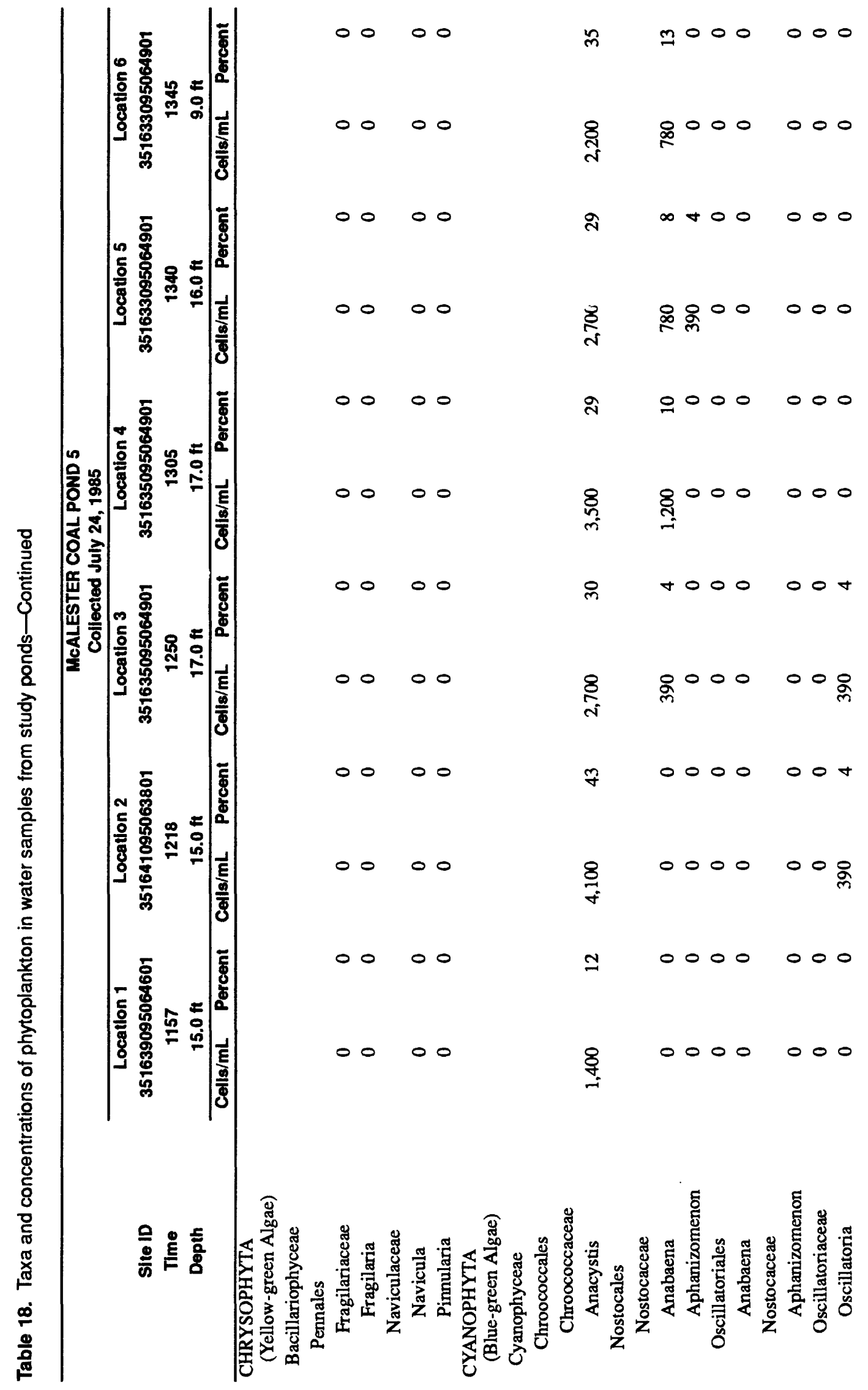




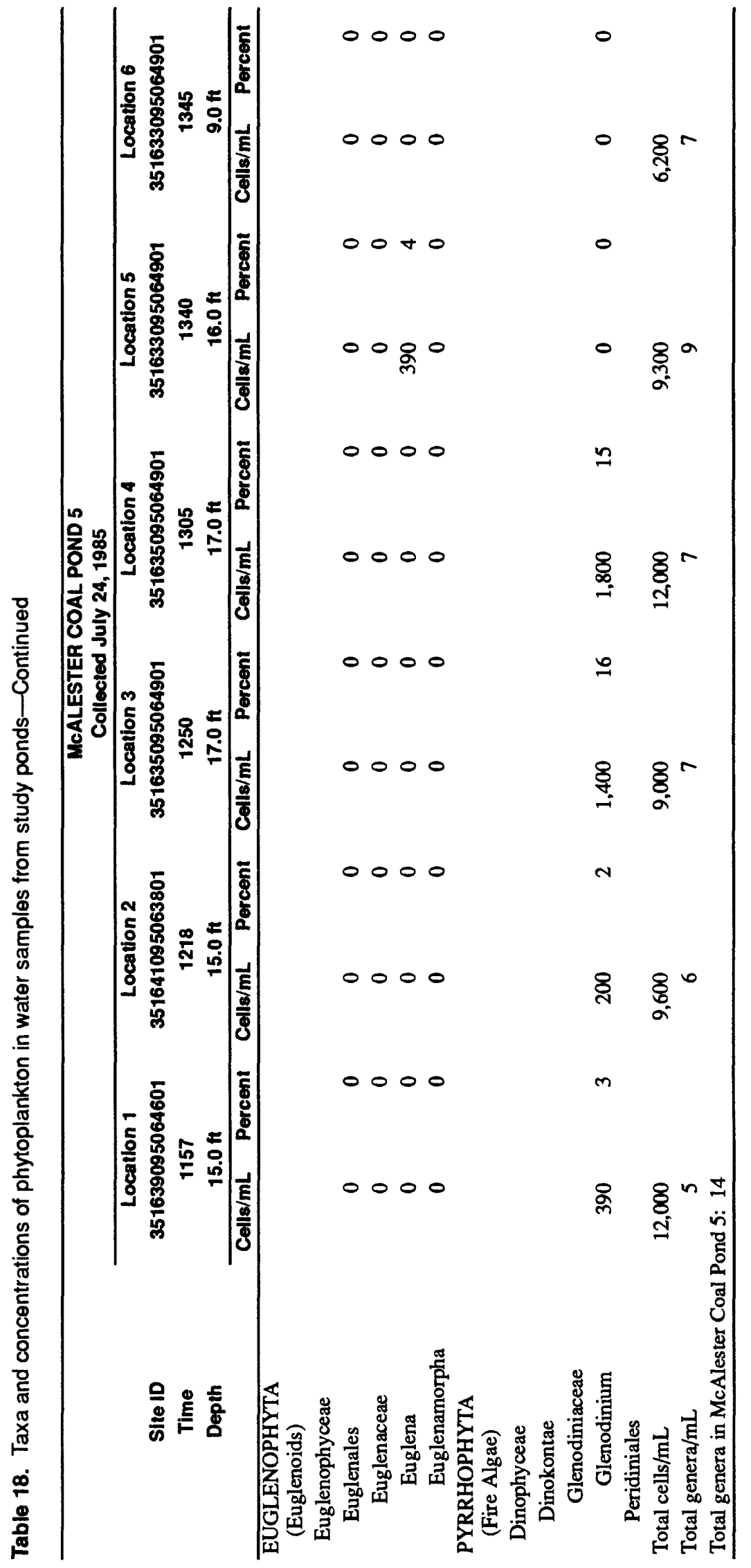




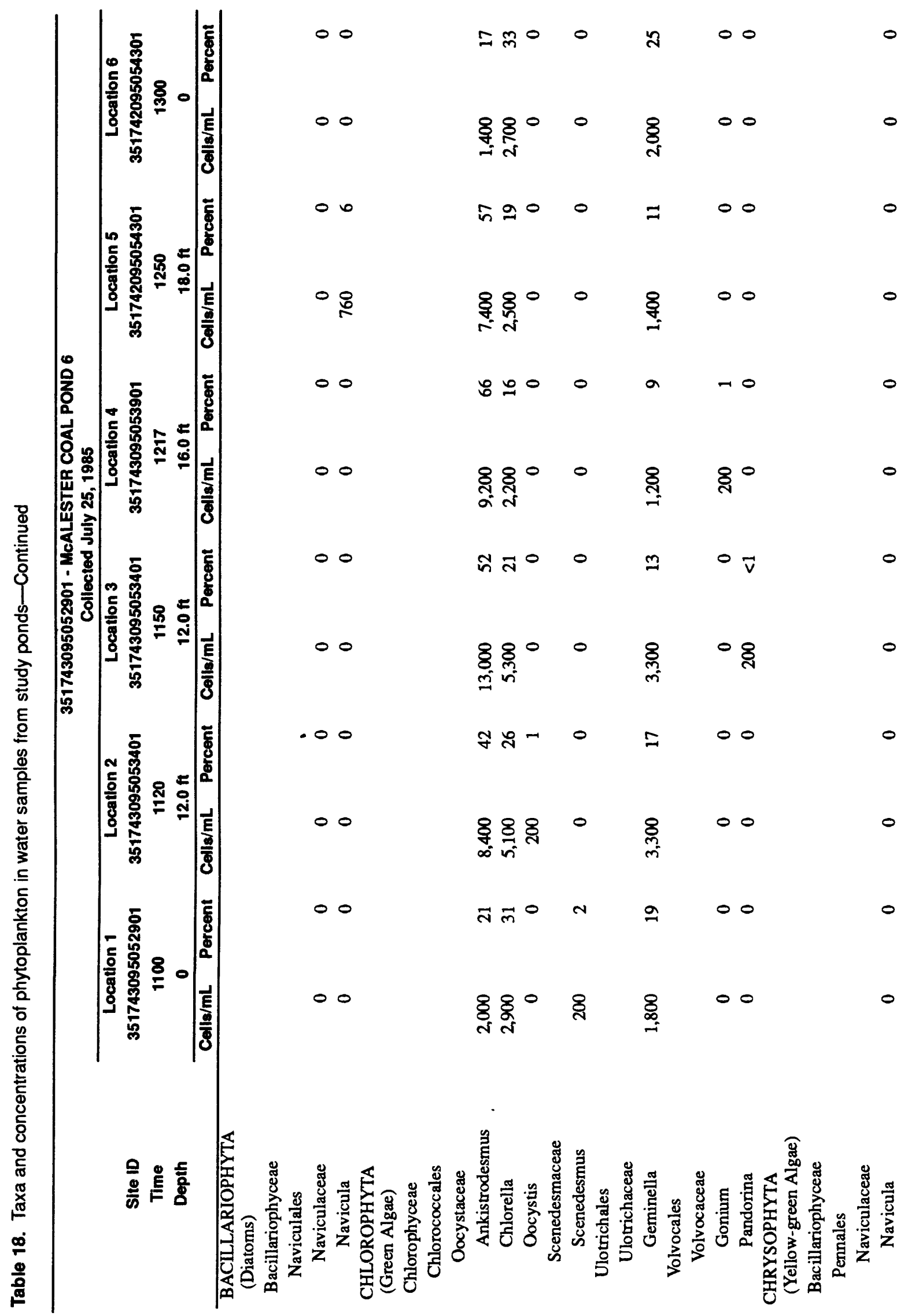




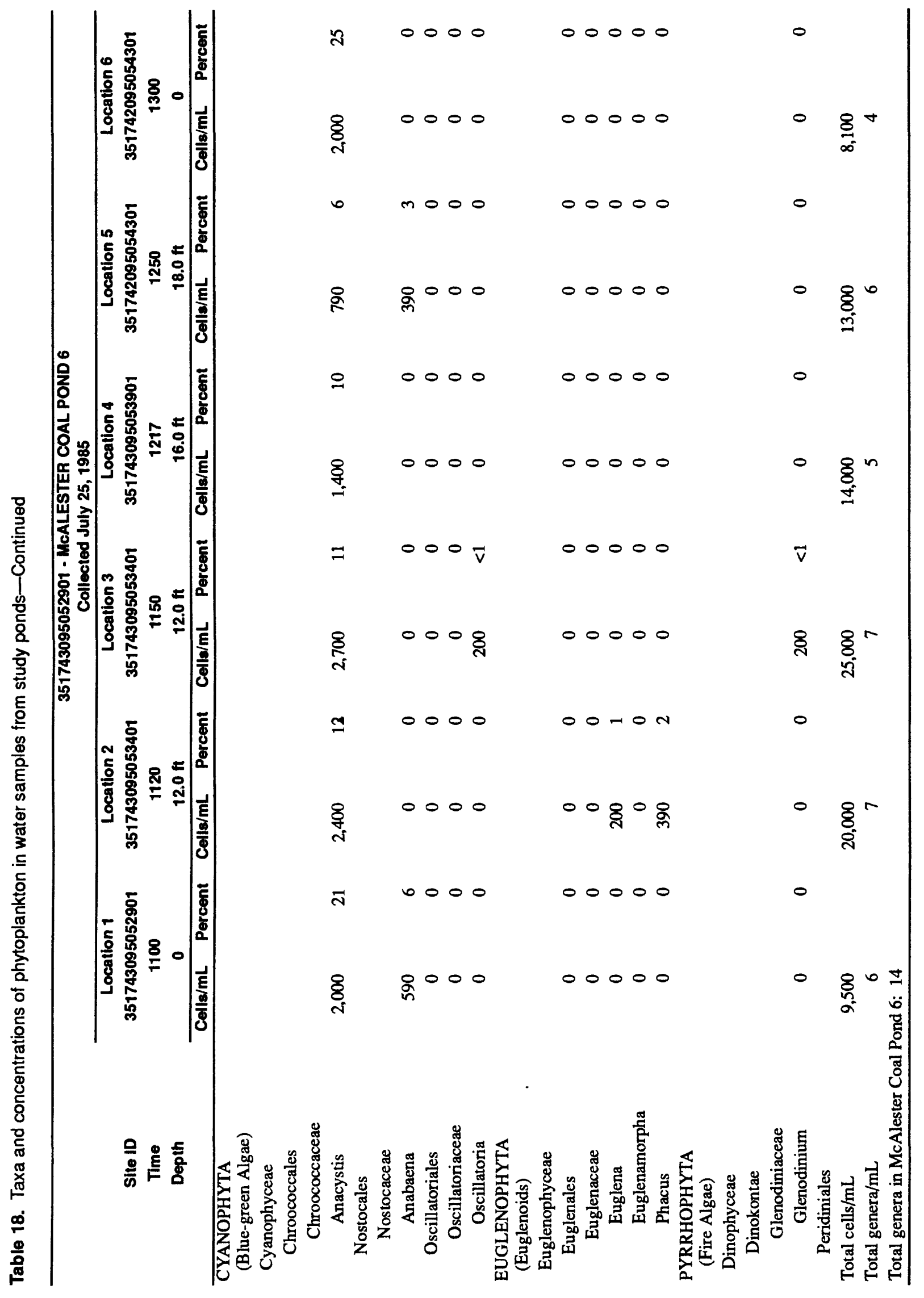




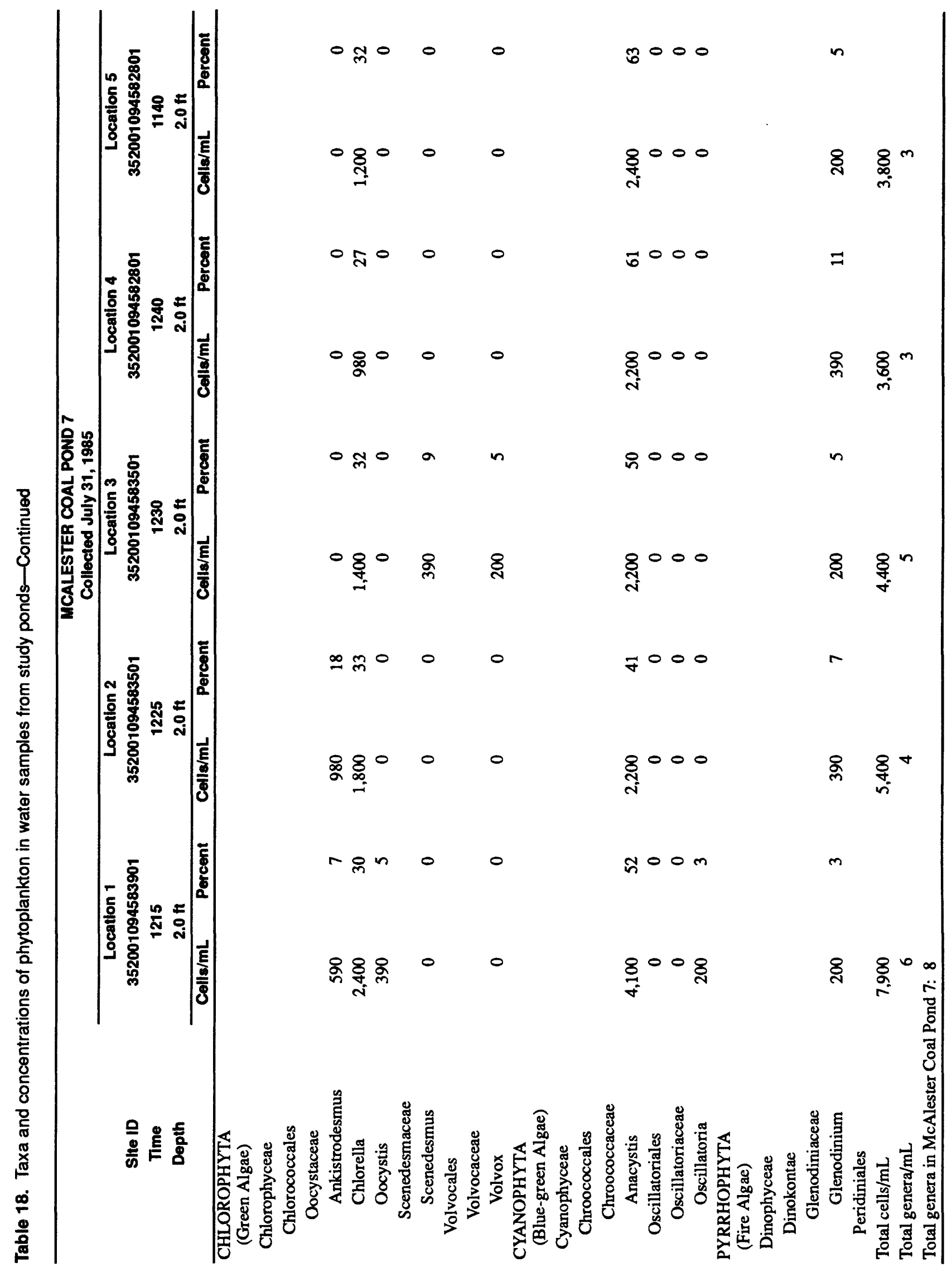




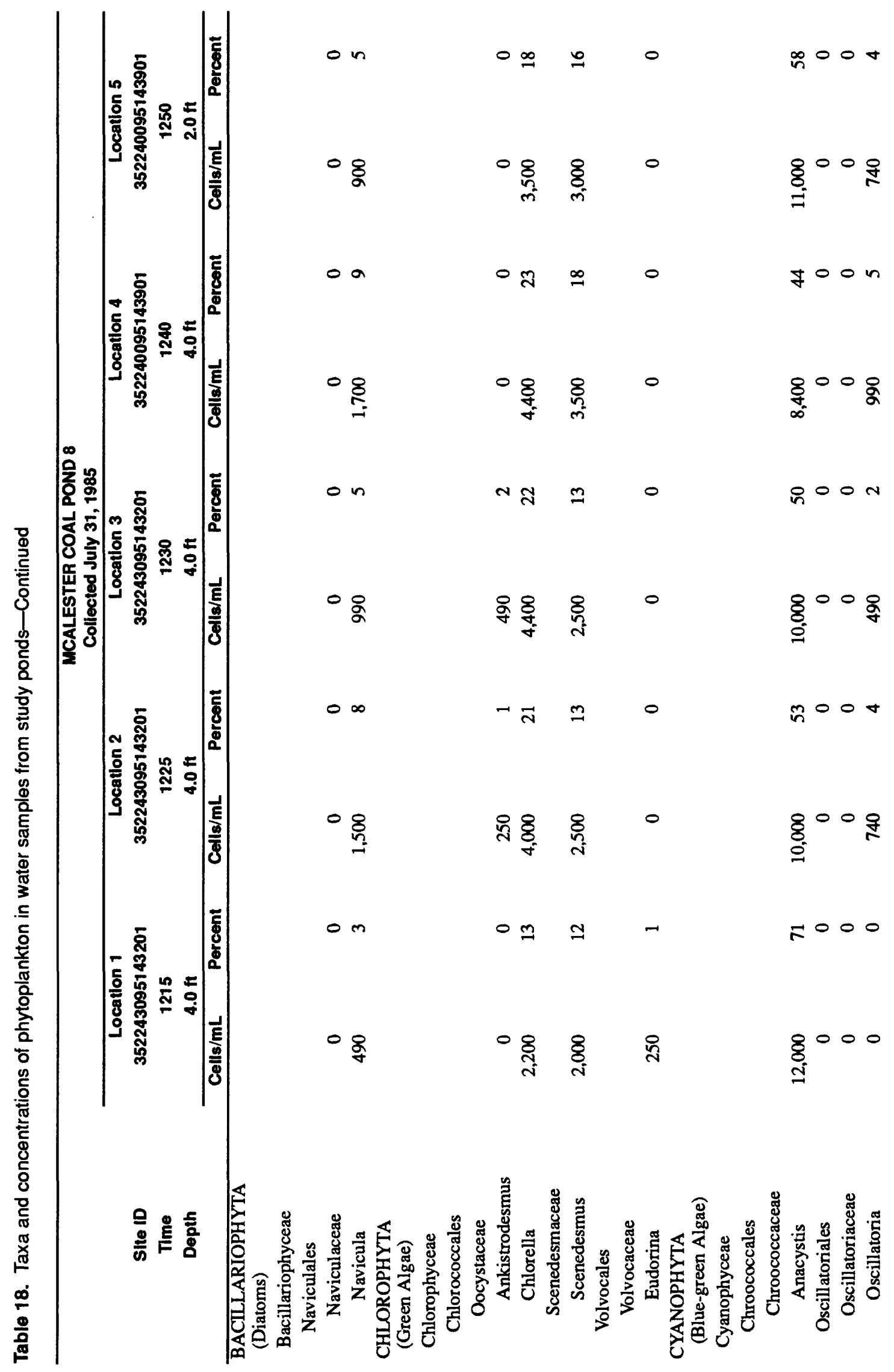




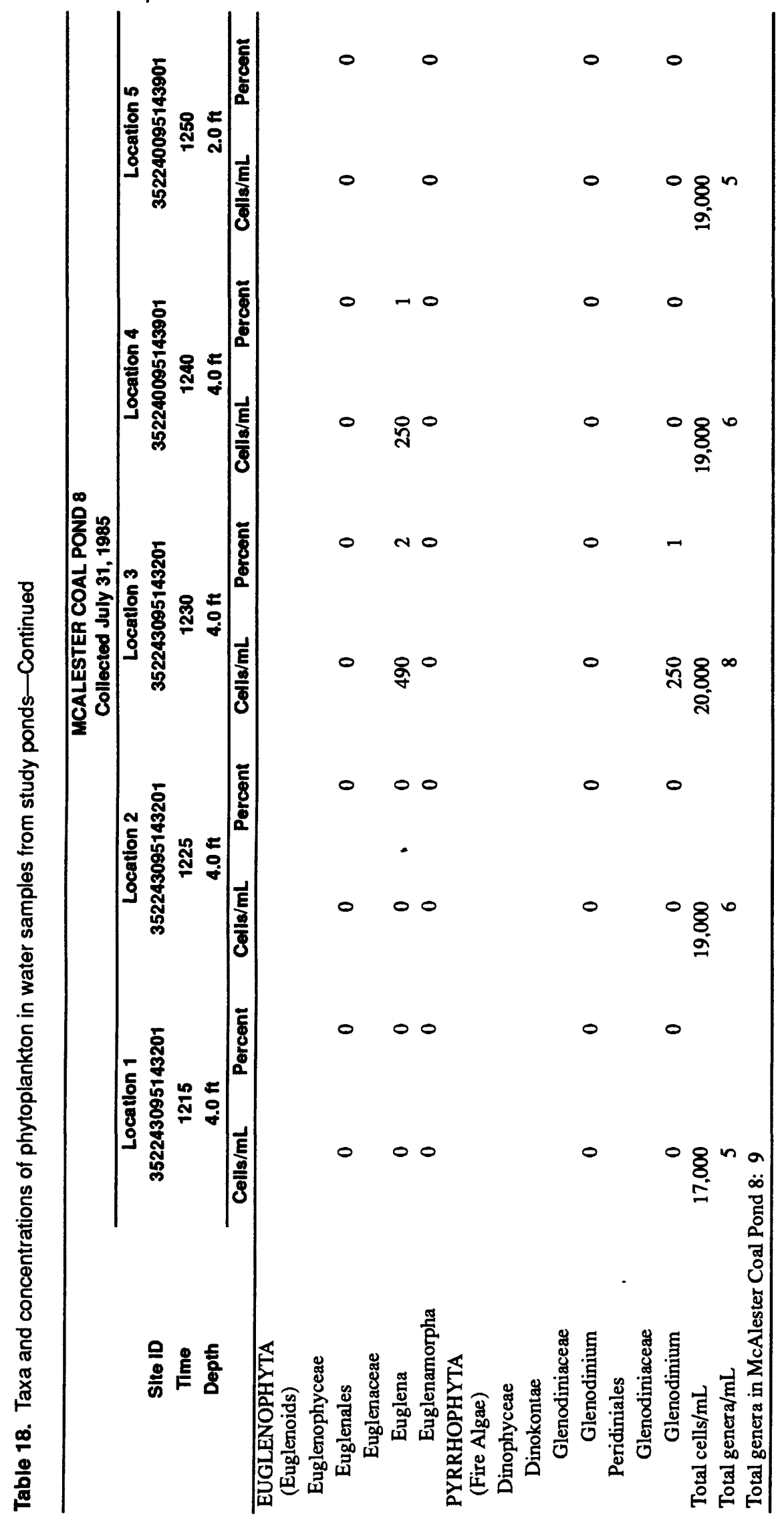




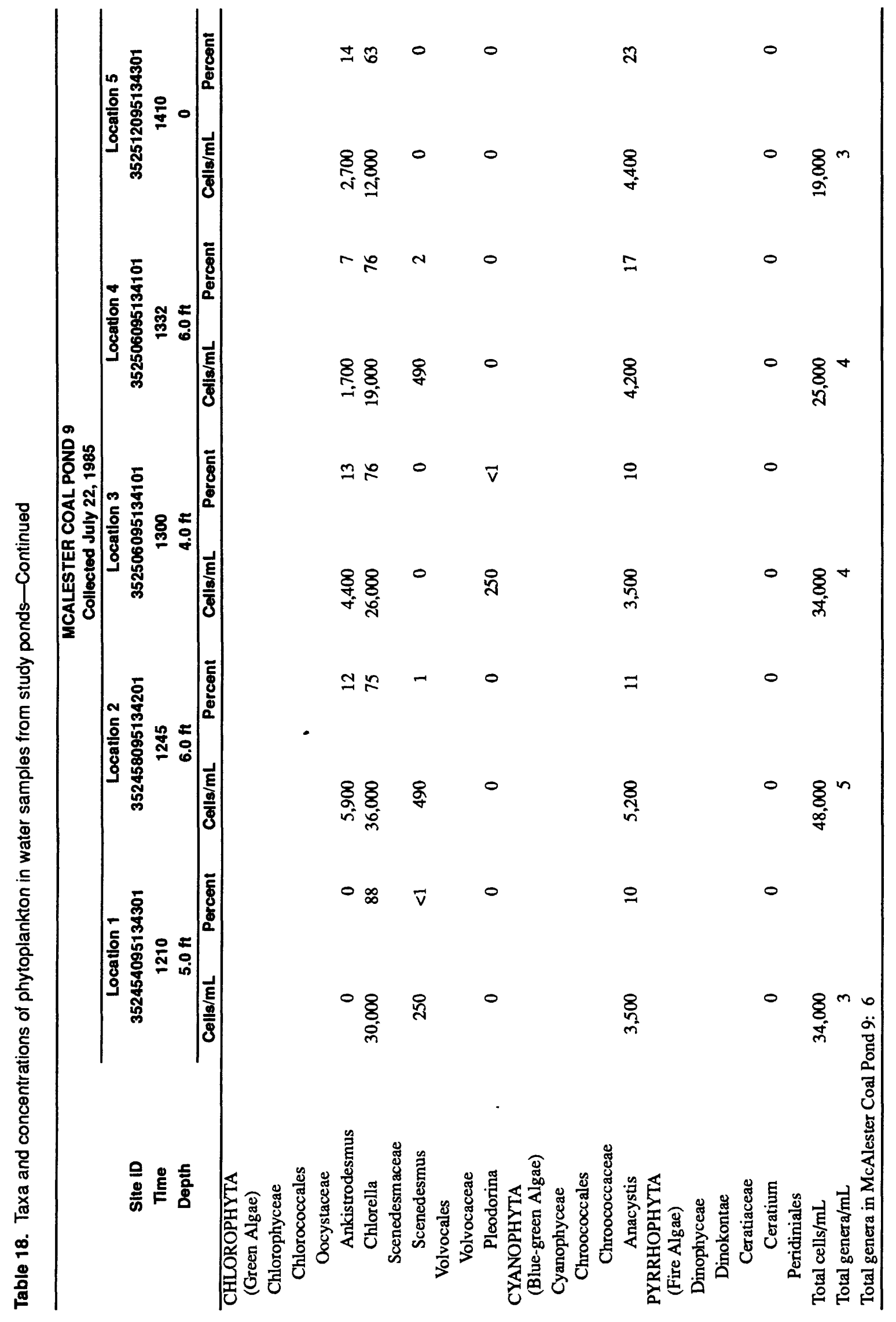


Table 19. Taxa and concentrations of benthic invertebrates in samples from study ponds

$\left[{ }^{*}\right.$, organisms are present in sample; **, cannot calculate because of missing data; ***, may be low because of missing data; <, less than; NA, not applicable; cells/mL, cells per milliliter]

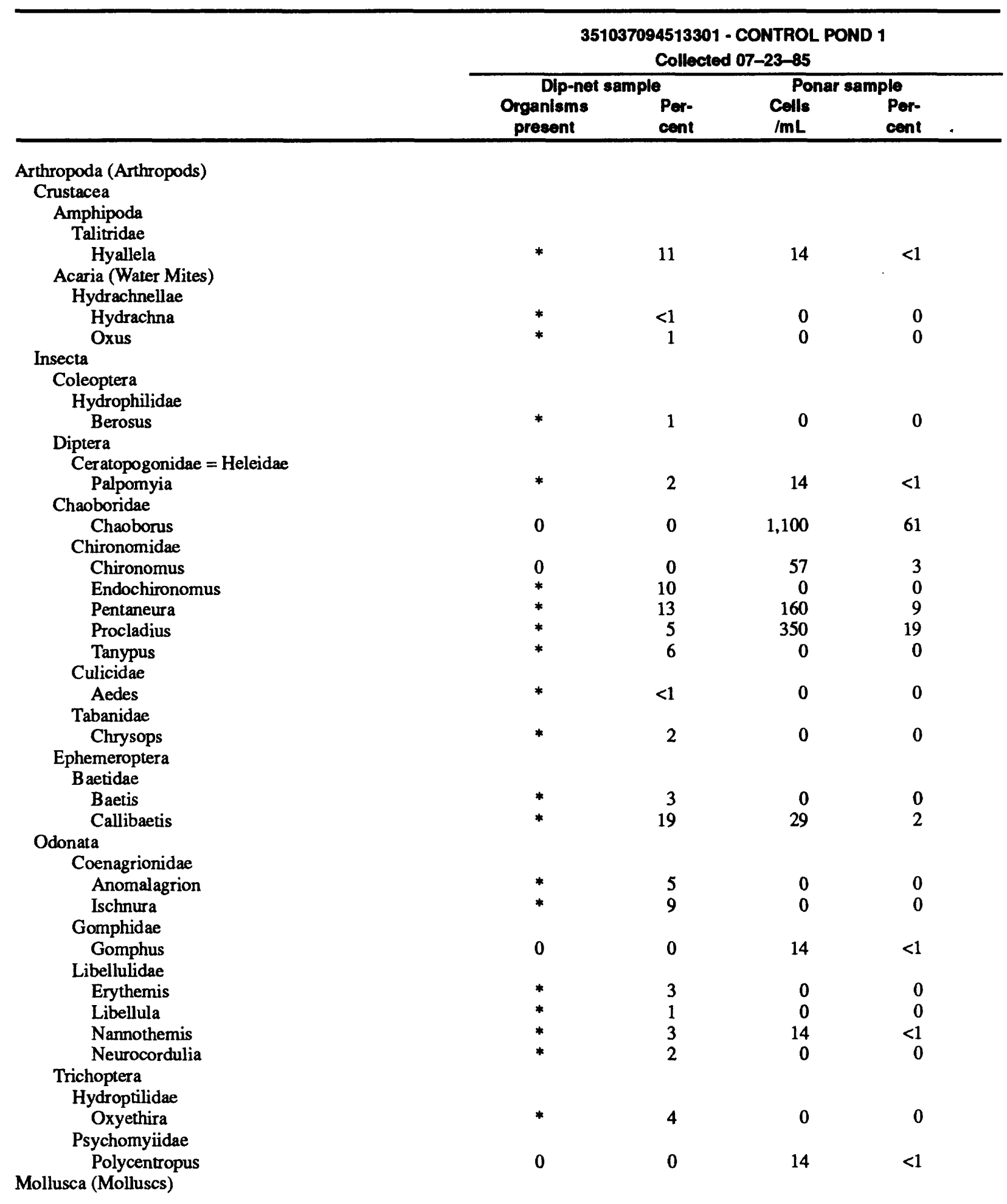


Table 19. Taxa and concentrations of benthic invertebrates in samples from study ponds-Continued

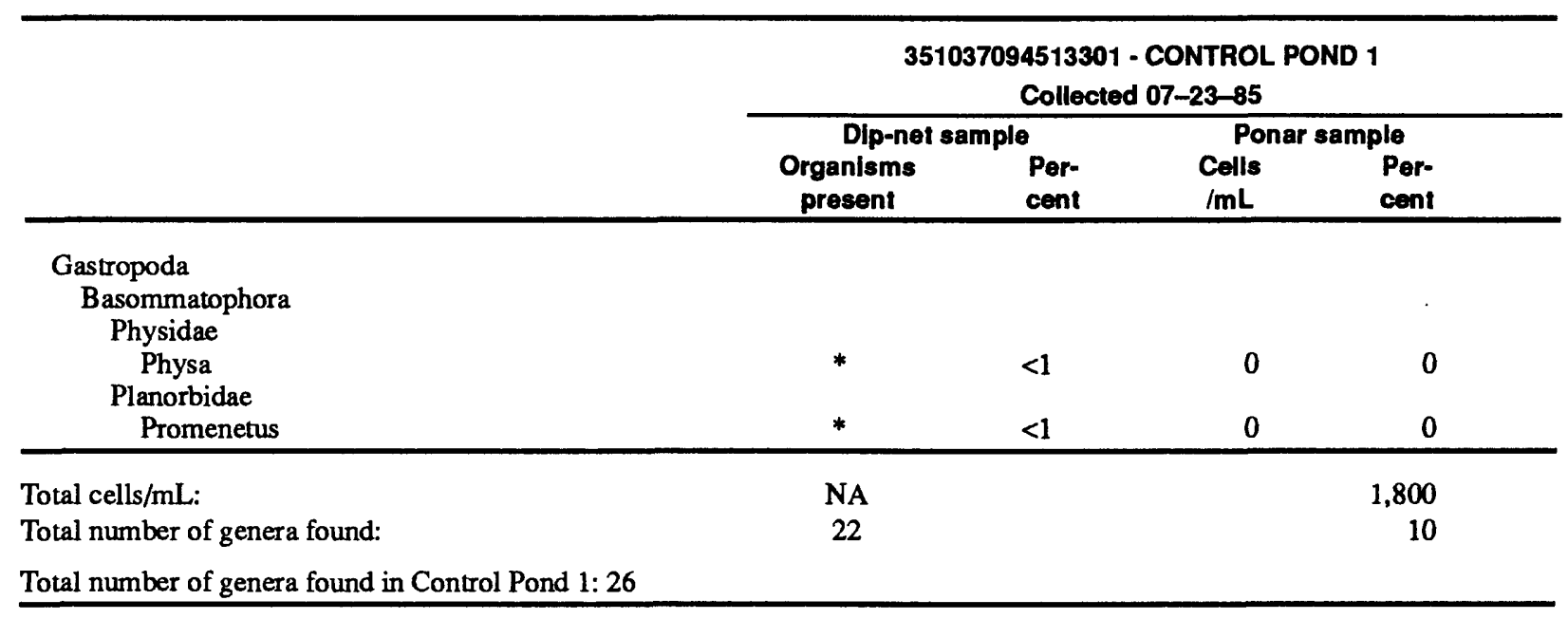


Table 19. Taxa and concentrations of benthic invertebrates in samples from study ponds-Continued

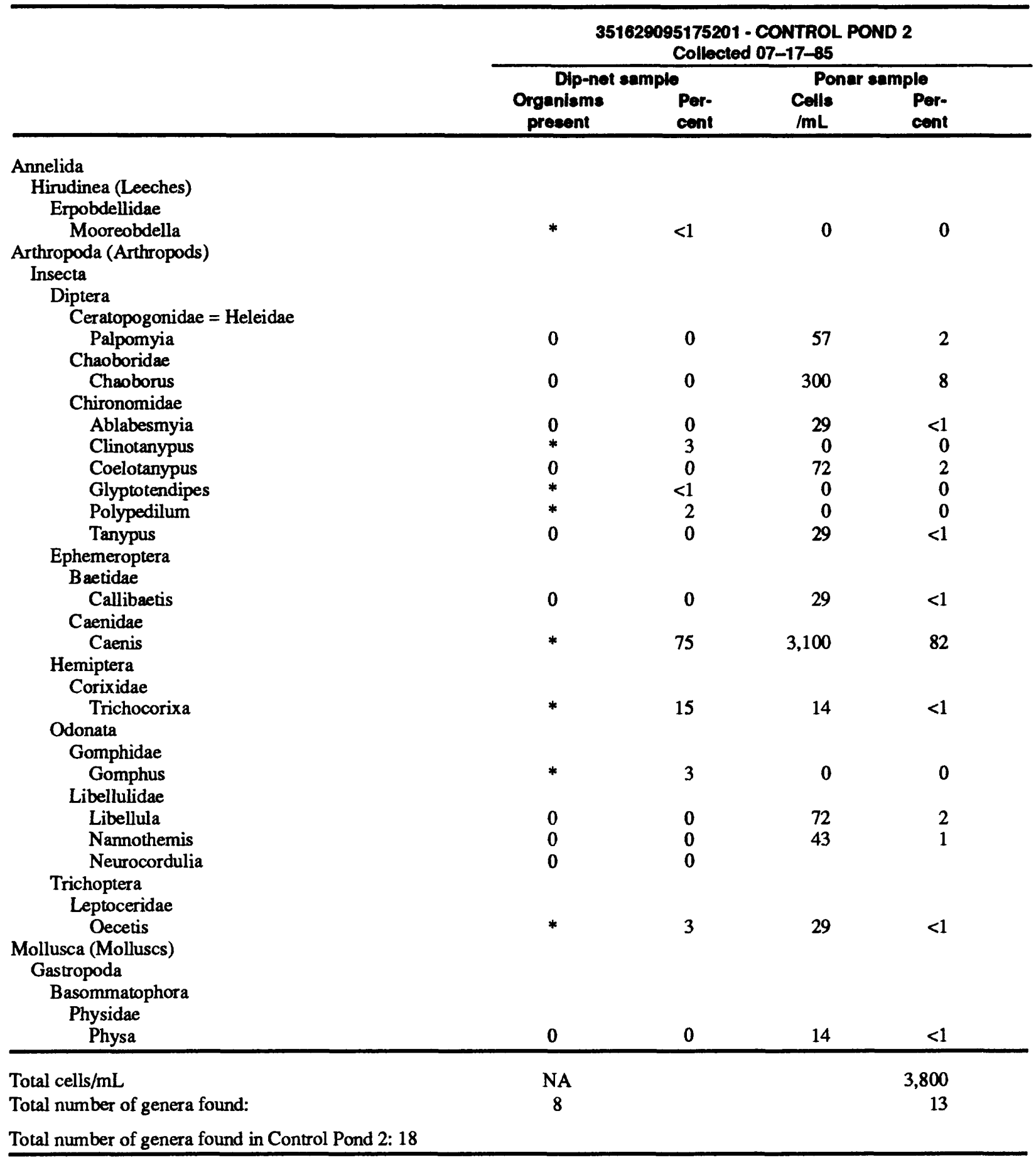


Table 19. Table 19.-Taxa and concentrations of benthic invertebrates in samples from study ponds-Continued

\begin{tabular}{|c|c|c|c|c|}
\hline & \multicolumn{4}{|c|}{$\begin{array}{c}351718094430301 \text { - CONTROL POND } 3 \\
\text { Collected 07-25-85 }\end{array}$} \\
\hline & $\begin{array}{c}\text { Dip-net } \\
\text { Organisms } \\
\text { present }\end{array}$ & $\begin{array}{l}\text { Per- } \\
\text { cent }\end{array}$ & $\begin{array}{l}\text { Pon } \\
\text { Colls } \\
/ \mathrm{mL}\end{array}$ & $\begin{array}{l}\text { ple } \\
\text { Per- } \\
\text { cent }\end{array}$ \\
\hline \multicolumn{5}{|l|}{ Arthropoda (Arthropods) } \\
\hline \multicolumn{5}{|l|}{ Insecta } \\
\hline \multicolumn{5}{|l|}{ Coleoptera } \\
\hline \multicolumn{5}{|l|}{ Dytiscidae } \\
\hline Uvarus & * & 1 & & \\
\hline \multicolumn{5}{|l|}{ Hydrophilidae } \\
\hline \multirow{2}{*}{\multicolumn{5}{|c|}{ Ephemeroptera }} \\
\hline & & & & \\
\hline \multicolumn{5}{|l|}{ Baetidae } \\
\hline Callibaetis & * & 1 & & \\
\hline \multicolumn{5}{|l|}{ Caenidae } \\
\hline Caenis & * & 60 & & \\
\hline \multicolumn{5}{|l|}{ Heptageniidae } \\
\hline Heptagenia & * & 2 & & \\
\hline \multicolumn{5}{|l|}{ Odonata } \\
\hline \multicolumn{5}{|l|}{ Coenagrionidae } \\
\hline Anomalagrion & $*$ & 4 & & \\
\hline Argia & * & 1 & & \\
\hline \multicolumn{5}{|l|}{ Corduliidae } \\
\hline Epitheca & * & 3 & & \\
\hline \multicolumn{5}{|l|}{ Gomphidae } \\
\hline Gomphus & * & 2 & & \\
\hline \multicolumn{5}{|l|}{ Libellulidae } \\
\hline Miathyria & * & 1 & & \\
\hline Nannothemis & * & 1 & & \\
\hline \multicolumn{5}{|l|}{ Mollusca (Molluscs) } \\
\hline \multicolumn{5}{|l|}{ Bivalvia } \\
\hline \multirow{2}{*}{\multicolumn{5}{|c|}{$\begin{array}{l}\text { Nuculoidea } \\
\text { Sphaeriidae }\end{array}$}} \\
\hline \multicolumn{4}{|l|}{ Sphaeriidae } & \\
\hline Sphaerium & * & 1 & & \\
\hline \multicolumn{5}{|l|}{ Gastropoda } \\
\hline \multirow{2}{*}{\multicolumn{5}{|c|}{ Basommatophora }} \\
\hline \multicolumn{2}{|l|}{ Lymnaeidae } & & & \\
\hline Lymnaea & * & 1 & & \\
\hline \multicolumn{5}{|l|}{ Physidae } \\
\hline Physa & * & 4 & & \\
\hline Planorbidae & & & & \\
\hline Helisoma & * & 17 & & \\
\hline Total cells/mL: & NA & & & ** \\
\hline Total number of genera found: & 15 & & & ** \\
\hline Total number of genera found in & & & & \\
\hline
\end{tabular}


Table 19. Table 19.-Taxa and concentrations of benthic invertebrates in samples from study ponds-Continued

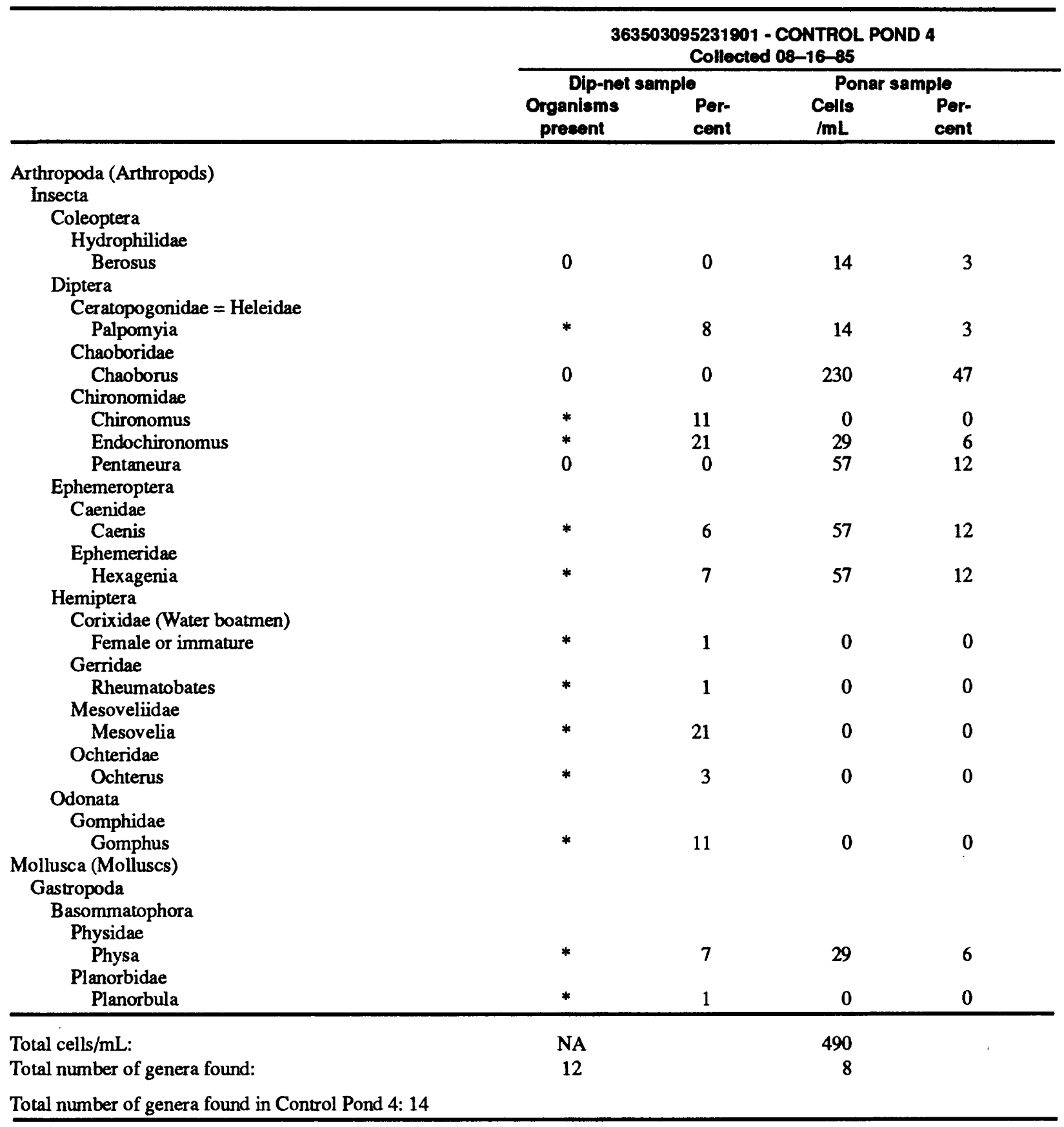


Table 19. Table 19.-Taxa and concentrations of benthic invertebrates in samples from study ponds-Continued

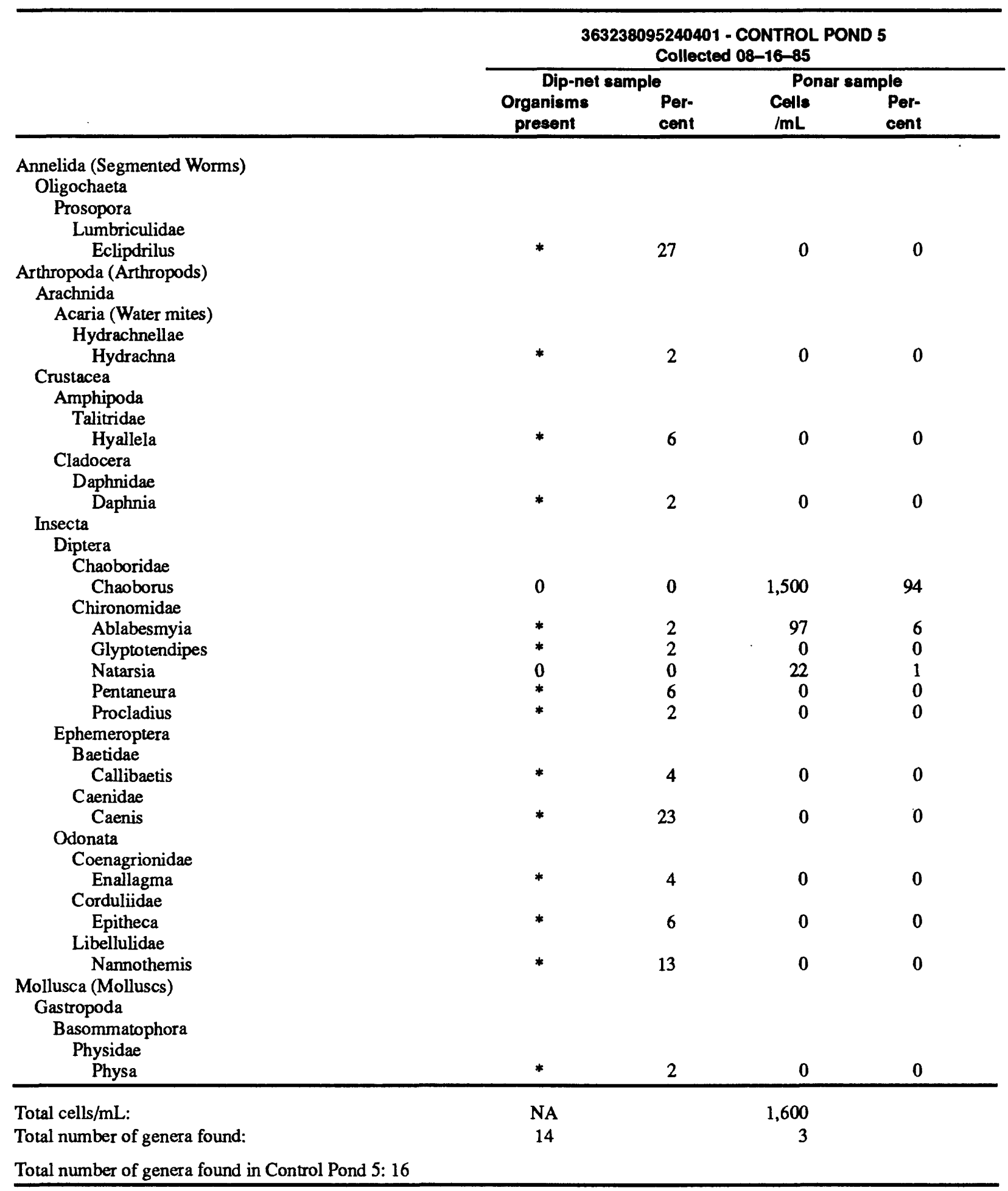


Table 19. Table 19.-Taxa and concentrations of benthic invertebrates in samples from study ponds-Continued

\begin{tabular}{|c|c|c|c|c|}
\hline & \multicolumn{4}{|c|}{$\begin{array}{c}360704095433601 \text { - CROWEBURG POND } 1 \\
\text { Collected 08-13-85 }\end{array}$} \\
\hline & $\begin{array}{c}\text { Dip-net } \\
\text { Organisms } \\
\text { present }\end{array}$ & $\begin{array}{l}\text { Per- } \\
\text { cent }\end{array}$ & $\begin{array}{l}\text { Pon } \\
\text { Colls } \\
\text { /mL }\end{array}$ & $\begin{array}{l}\text { ple } \\
\text { Per- } \\
\text { cent }\end{array}$ \\
\hline \multicolumn{5}{|l|}{ Arthropoda (Arthropods) } \\
\hline \multicolumn{5}{|l|}{ Crustacea } \\
\hline \multicolumn{5}{|l|}{ Amphipoda } \\
\hline \multicolumn{5}{|l|}{ Talitridae } \\
\hline Hyallela & * & 3 & $\mathbf{0}$ & $\mathbf{0}$ \\
\hline \multicolumn{5}{|l|}{ Insecta } \\
\hline \multicolumn{5}{|l|}{ Coleoptera } \\
\hline \multicolumn{5}{|l|}{ Hydrophilidae } \\
\hline Berosus & * & 2 & $\mathbf{0}$ & 0 \\
\hline \multicolumn{5}{|l|}{ Diptera } \\
\hline \multicolumn{5}{|l|}{ Chaoboridae } \\
\hline Chaoborus & 0 & 0 & 2,400 & 99 \\
\hline \multicolumn{5}{|l|}{ Chironomidae } \\
\hline Chironomus & * & 5 & $\mathbf{0}$ & $\mathbf{0}$ \\
\hline Dicrotendipes-Microtendipes & * & 2 & $\mathbf{0}$ & $\mathbf{0}$ \\
\hline Endochironomus* & * & 3 & $\mathbf{0}$ & $\mathbf{0}$ \\
\hline Rheotanytarsus & * & 8 & $\mathbf{0}$ & $\mathbf{0}$ \\
\hline \multicolumn{5}{|l|}{ Ephemeroptera } \\
\hline \multicolumn{5}{|l|}{ Caenidae } \\
\hline Caenis & * & 20 & $\mathbf{0}$ & $\mathbf{0}$ \\
\hline \multicolumn{5}{|l|}{ Hemiptera } \\
\hline \multicolumn{5}{|l|}{ Corixidae (Water boatmen) } \\
\hline Female or immature & * & 3 & $\mathbf{0}$ & $\mathbf{0}$ \\
\hline \multicolumn{5}{|l|}{ Pleidae (False back swimmers) } \\
\hline Neoplea & 0 & 0 & 22 & $<1$ \\
\hline \multicolumn{5}{|l|}{ Odonata } \\
\hline \multicolumn{5}{|l|}{ Coenagrionidae } \\
\hline Anomalagrion & * & 30 & $\mathbf{0}$ & $\mathbf{0}$ \\
\hline Ischnura & * & 3 & $\mathbf{0}$ & $\mathbf{0}$ \\
\hline Libellulidae & * & 7 & $\mathbf{0}$ & $\mathbf{0}$ \\
\hline Neurocordulia & * & 3 & $\mathbf{0}$ & 0 \\
\hline Somatochlora & * & 3 & $\mathbf{0}$ & 0 \\
\hline \multicolumn{5}{|l|}{ Mollusca (Molluscs) } \\
\hline \multirow{2}{*}{\multicolumn{5}{|c|}{$\begin{array}{l}\text { Gastropoda } \\
\text { Basommatophora }\end{array}$}} \\
\hline & & & & \\
\hline \multicolumn{5}{|l|}{ Physidae } \\
\hline Physa & $*$ & 8 & 0 & $\mathbf{0}$ \\
\hline Total cells/mL: & NA & & 2,400 & \\
\hline Total number of genera found: & 14 & & 2 & \\
\hline Total number of genera found in Crowebur & & & & \\
\hline
\end{tabular}


Table 19. Table 19.-Taxa and concentrations of benthic invertebrates in samples from study ponds-Continued

\begin{tabular}{|c|c|c|c|c|}
\hline & \multicolumn{4}{|c|}{$\begin{array}{c}\text { 361604095400401 - CROWEBURG POND } 2 \\
\text { Collected 08-01-85 }\end{array}$} \\
\hline & $\begin{array}{c}\text { Dip-ne } \\
\text { Organisms } \\
\text { present }\end{array}$ & $\begin{array}{l}\text { Per- } \\
\text { cent }\end{array}$ & $\begin{array}{c}\text { Por } \\
\text { Colls } \\
\text { /mL }\end{array}$ & $\begin{array}{l}\text { ple } \\
\text { Per- } \\
\text { cent }\end{array}$ \\
\hline \multicolumn{5}{|l|}{ Arthropoda (Arthropods) } \\
\hline Coleoptera & \multicolumn{4}{|c|}{ Insecta } \\
\hline \multicolumn{5}{|l|}{ Dytiscidae } \\
\hline Hydrovatus & * & 5 & 0 & 0 \\
\hline \multicolumn{5}{|l|}{ Haliplidae } \\
\hline Peltodytes & * & 3 & 0 & 0 \\
\hline \multicolumn{5}{|c|}{ Diptera } \\
\hline \multicolumn{5}{|c|}{ Ceratopogonidae $=$ Heleidae } \\
\hline Chaoborus & 0 & 0 & 2200 & 54 \\
\hline \multicolumn{5}{|l|}{ Chironomidae } \\
\hline Cryptochironomus & * & 2 & 0 & 0 \\
\hline Microtendipes & * & 5 & 150 & 4 \\
\hline Pentaneura & * & 9 & 0 & 0 \\
\hline Procladius & * & 2 & 0 & 0 \\
\hline \multicolumn{5}{|l|}{ Culicidae } \\
\hline Culex & * & 1 & 0 & 0 \\
\hline \multicolumn{5}{|l|}{ Ephemeroptera } \\
\hline \multicolumn{5}{|l|}{ Baetidae } \\
\hline Callibaetis & * & 1 & 0 & 0 \\
\hline Caenidae & & & & \\
\hline Caenis & * & 11 & $\mathbf{0}$ & 0 \\
\hline \multicolumn{5}{|l|}{ Megaloptera } \\
\hline \multicolumn{5}{|l|}{ Sialidae } \\
\hline Sialis & * & 2 & 0 & 0 \\
\hline \multicolumn{5}{|l|}{ Odonata } \\
\hline \multicolumn{5}{|l|}{ Coenagrionidae } \\
\hline Anomalagrion & * & 5 & 0 & 0 \\
\hline Argia & * & 2 & 0 & 0 \\
\hline \multicolumn{5}{|l|}{ Corduliidae } \\
\hline Epitheca & * & 2 & 0 & 0 \\
\hline \multicolumn{5}{|l|}{ Gomphidae } \\
\hline Gomphus & * & 4 & 0 & 0 \\
\hline \multicolumn{5}{|l|}{ Libellulidae } \\
\hline Miathyria & * & 2 & 0 & 0 \\
\hline Nannothemis & * & 2 & 0 & 0 \\
\hline Macromïdae & & & & \\
\hline Didymops & * & 1 & $\mathbf{0}$ & 0 \\
\hline Mollusca (Molluscs) & & & & \\
\hline Gastropoda & & & & \\
\hline Basommatophora & & & & \\
\hline Physidae & & & & \\
\hline Physa & * & 37 & 780 & 19 \\
\hline Planorbidae & & & & \\
\hline Promenetus & * & 4 & 1,000 & 24 \\
\hline Total cells/mL: & NA & & 4,100 & \\
\hline Total number of genera found: & 20 & & 4 & \\
\hline Total number of genera found in & & & & \\
\hline
\end{tabular}


Table 19. Table 19.-Taxa and concentrations of benthic invertebrates in samples from study ponds-Continued

\begin{tabular}{|c|c|c|c|c|}
\hline & \multicolumn{4}{|c|}{$\begin{array}{c}362335095364901 \text { - CROWEBURG POND } 3 \\
\text { Collected 08-01-85 }\end{array}$} \\
\hline & $\begin{array}{c}\text { Dip-net } \\
\text { Organisms } \\
\text { present }\end{array}$ & $\begin{array}{l}\text { Per- } \\
\text { cont }\end{array}$ & $\begin{array}{l}\text { Por } \\
\text { Cells } \\
/ \mathrm{mL} \\
\end{array}$ & $\begin{array}{l}\text { Pele } \\
\text { Per- } \\
\text { cent }\end{array}$ \\
\hline \multicolumn{5}{|c|}{ Annelida (Segmented Worms) } \\
\hline \multicolumn{5}{|c|}{ Oligochaeta } \\
\hline \multicolumn{5}{|l|}{ Plesiopora } \\
\hline \multicolumn{5}{|l|}{ Tubificidae } \\
\hline $\begin{array}{l}\text { Branchiura } \\
\text { Arthropoda (Arthropods }\end{array}$ & 0 & 0 & 130 & 4 \\
\hline \multicolumn{5}{|l|}{ Arthropoda (Arthropods) } \\
\hline \multicolumn{5}{|l|}{ Crustacea } \\
\hline \multirow{2}{*}{\multicolumn{5}{|c|}{$\begin{array}{r}\text { Amphipoda } \\
\text { Talitridae }\end{array}$}} \\
\hline & & & & \\
\hline Hyallela & * & 5 & $\mathbf{0}$ & 0 \\
\hline \multicolumn{5}{|l|}{ Insecta } \\
\hline \multicolumn{5}{|l|}{ Coleoptera } \\
\hline Chrysomelidae & & & & \\
\hline Donacia & * & 1 & 0 & 0 \\
\hline \multicolumn{5}{|l|}{ Elmidae } \\
\hline Dubiraphia & * & 5 & 0 & 0 \\
\hline Stenelmis & * & 1 & $\mathbf{0}$ & 0 \\
\hline \multicolumn{5}{|l|}{ Haliplidae } \\
\hline Peltodytes & * & 1 & $\mathbf{0}$ & $\mathbf{0}$ \\
\hline \multicolumn{5}{|l|}{ Hydrophilidae } \\
\hline Berosus & $*$ & 2 & 0 & 0 \\
\hline \multicolumn{5}{|c|}{ Diptera } \\
\hline \multicolumn{5}{|c|}{ Ceratopogonidae $=$ Heleidae } \\
\hline Palpomyia & * & 1 & $\mathbf{0}$ & 0 \\
\hline Chaoboridae & & & & \\
\hline Chaoborus & 0 & 0 & 43 & 1 \\
\hline Chironomidae & & & & \\
\hline Chironomus & 0 & 0 & 560 & 18 \\
\hline Pentaneura & * & 1 & 470 & 15 \\
\hline Polypedilum & * & 7 & 0 & 0 \\
\hline Procladius & 0 & 0 & 220 & 7 \\
\hline Tanypus & 0 & 0 & 220 & 7 \\
\hline Culicidae & & & & \\
\hline Culex & * & 2 & 0 & $\mathbf{0}$ \\
\hline Tabanidae & & & & \\
\hline Tabanus & * & 1 & 0 & 0 \\
\hline $\begin{array}{l}\text { Ephemeroptera } \\
\text { Baetidae }\end{array}$ & & & & \\
\hline Callibaetis & * & 2 & 0 & $\mathbf{0}$ \\
\hline Caenidae & & & & \\
\hline Caenis & * & 19 & 170 & 5 \\
\hline Ephemeridae & & & & \\
\hline Hexagenia & $\mathbf{0}$ & 0 & 22 & $<1$ \\
\hline Hemiptera & & & & \\
\hline Veliidae & & & & \\
\hline Microvelia & * & 1 & 350 & 11 \\
\hline Megaloptera & & & & \\
\hline Sialidae & & & & \\
\hline Sialis & 0 & 0 & 43 & 1 \\
\hline Odonata & & & & \\
\hline Gomphidae & & & & \\
\hline Gomphus & 0 & 0 & 22 & $<1$ \\
\hline Lestidae & & & & \\
\hline Lestes & 0 & 0 & 22 & $<1$ \\
\hline Macromiidae & & & & \\
\hline Macromia & $\mathbf{0}$ & 0 & 22 & $<1$ \\
\hline
\end{tabular}


Table 19. Table 19.-Taxa and concentrations of benthic invertebrates in samples from study ponds-Continued

\begin{tabular}{|c|c|c|c|c|}
\hline & \multicolumn{4}{|c|}{$\begin{array}{l}\text { 362335095364901 - CROWEBURG POND } 3 \\
\text { Collected 08-01-85 }\end{array}$} \\
\hline & $\begin{array}{c}\text { Dip-net } \\
\text { Organlsms } \\
\text { present }\end{array}$ & $\begin{array}{l}\text { le } \\
\text { Per- } \\
\text { cent }\end{array}$ & $\begin{array}{l}\text { Pon } \\
\text { Cells } \\
/ \mathrm{mL}\end{array}$ & $\begin{array}{l}\text { Ple } \\
\text { Per- } \\
\text { cent }\end{array}$ \\
\hline $\begin{array}{c}\text { Mollusca (Molluscs) } \\
\text { Bivalvia } \\
\text { Schizodonta } \\
\text { Unionidae } \\
\text { Anodonta } \\
\text { Gastropoda } \\
\text { Basommatophora } \\
\text { Physidae } \\
\text { Physa } \\
\text { Planorbidae } \\
\text { Promenetus } \\
\end{array}$ & * & $\begin{array}{r}47 \\
1 \\
\end{array}$ & $\begin{array}{l}540 \\
350 \\
\end{array}$ & 17 \\
\hline $\begin{array}{l}\text { Total cells/mL: } \\
\text { Total number of genera found: }\end{array}$ & $\begin{array}{l}\text { NA } \\
17\end{array}$ & & $\begin{array}{r}3,200 \\
15\end{array}$ & \\
\hline Total number of genera found in Croweburg Pond 3: 27 & & & & \\
\hline
\end{tabular}


Table 19. Table 19.-Taxa and concentrations of benthic invertebrates in samples from study ponds-Continued

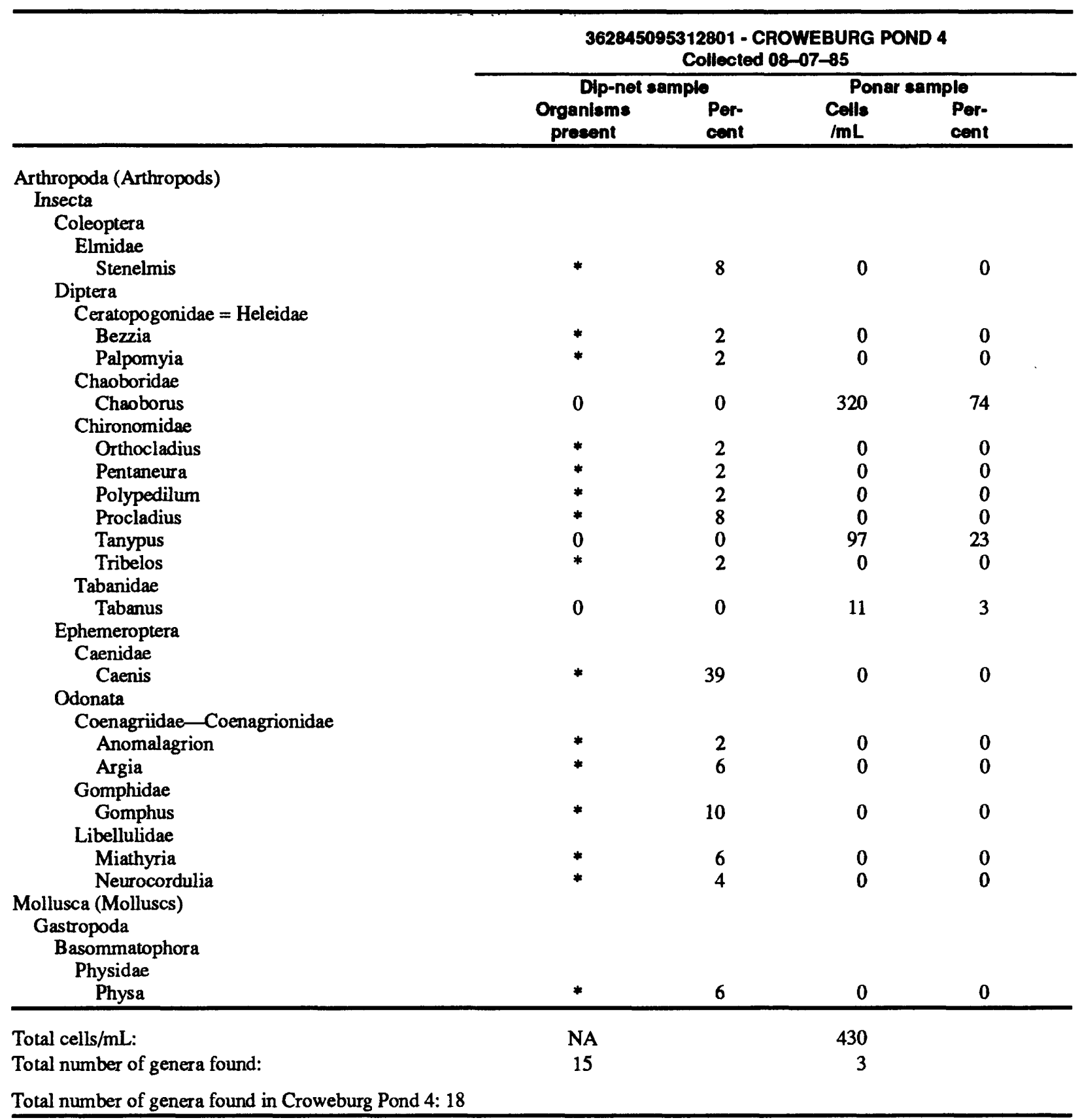


Table 19. Table 19.-Taxa and concentrations of benthic invertebrates in samples from study ponds-Continued

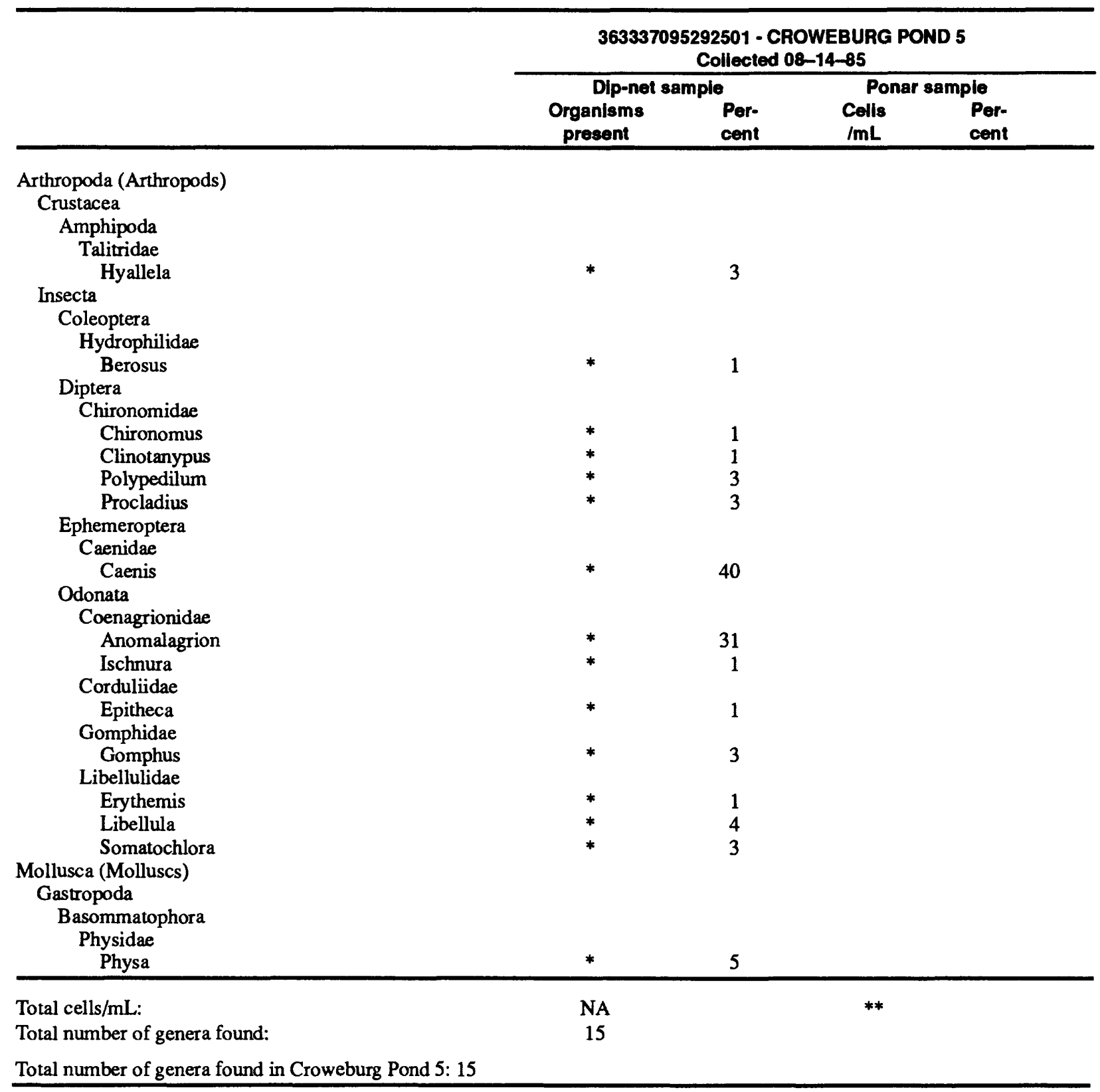


Table 19. Table 19.-Taxa and concentrations of benthic invertebrates in samples from study ponds-Continued

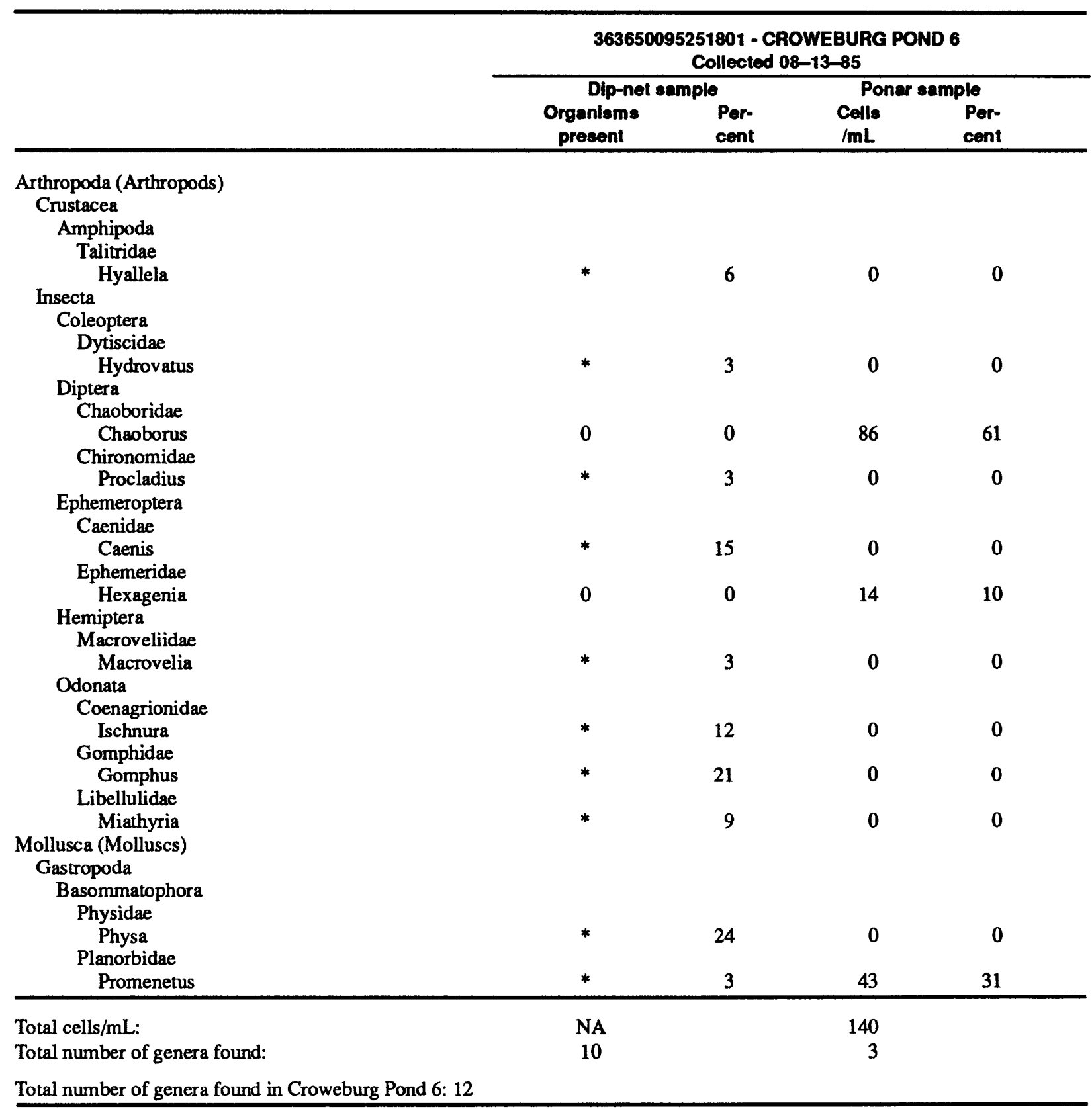


Table 19. Table 19.-Taxa and concentrations of benthic invertebrates in samples from study ponds-Continued

\begin{tabular}{|c|c|c|c|c|}
\hline & \multicolumn{4}{|c|}{$\begin{array}{l}364754095174201 \text { - CROWEBURG POND } 7 \\
\text { Collected 08-21-85 }\end{array}$} \\
\hline & $\begin{array}{c}\text { Dlp-net } \\
\text { Organlsms } \\
\text { present }\end{array}$ & $\begin{array}{l}\text { Per- } \\
\text { cent }\end{array}$ & $\begin{array}{l}\text { Por } \\
\text { Cells } \\
/ \mathrm{mL} \\
\end{array}$ & $\begin{array}{l}\text { ple } \\
\text { Per- } \\
\text { cent }\end{array}$ \\
\hline \multirow{2}{*}{\multicolumn{5}{|c|}{$\begin{array}{l}\text { Arthropoda (Arthropods) } \\
\text { Insecta }\end{array}$}} \\
\hline & & & & \\
\hline \multicolumn{5}{|l|}{ Diptera } \\
\hline \multicolumn{5}{|l|}{ Chaoboridae } \\
\hline Chaoborus & 0 & 0 & 280 & 60 \\
\hline \multicolumn{5}{|l|}{ Chironomidae } \\
\hline Chironomus & * & 3 & $\mathbf{0}$ & 0 \\
\hline Endochironomus & * & 6 & 0 & 0 \\
\hline Procladius & * & 3 & 43 & 9 \\
\hline \multirow{2}{*}{\multicolumn{5}{|c|}{$\begin{array}{l}\text { Ephemeroptera } \\
\text { Caenidae }\end{array}$}} \\
\hline & & & & \\
\hline Caenis & * & 12 & 43 & 9 \\
\hline \multicolumn{5}{|l|}{ Ephemeridae } \\
\hline Hexagenia & * & 3 & 65 & 14 \\
\hline \multicolumn{5}{|l|}{ Odonata } \\
\hline \multicolumn{5}{|l|}{ Coenagrionidae } \\
\hline Ischnura & * & 6 & $\mathbf{0}$ & 0 \\
\hline \multicolumn{5}{|l|}{ Gomphidae } \\
\hline Gomphus & * & 3 & 0 & 0 \\
\hline \multicolumn{5}{|l|}{ Libellulidae } \\
\hline Miathyria & * & 6 & 0 & 0 \\
\hline Neurocordulia & * & 12 & 0 & $\mathbf{0}$ \\
\hline \multirow{2}{*}{\multicolumn{5}{|c|}{ Trichoptera }} \\
\hline Psychomyiidae & & & & \\
\hline Polycentropus & * & 3 & $\mathbf{0}$ & $\mathbf{0}$ \\
\hline \multicolumn{5}{|l|}{ Mollusca (Molluscs) } \\
\hline \multirow{2}{*}{\multicolumn{5}{|c|}{ Gastropoda }} \\
\hline \multicolumn{2}{|l|}{ Basommatophora } & & & \\
\hline \multicolumn{5}{|l|}{ Physidae } \\
\hline Physa & * & 30 & 22 & 5 \\
\hline \multicolumn{5}{|l|}{ Planorbidae } \\
\hline Helisoma & * & 3 & 0 & 0 \\
\hline Promenetus & $*$ & 9 & 22 & 5 \\
\hline Total cells/mL: & NA & & 480 & \\
\hline Total number of genera found: & 13 & & 6 & \\
\hline Total number of genera found $i$ & & & & \\
\hline
\end{tabular}


Table 19. Table 19.-Taxa and concentrations of benthic invertebrates in samples from study ponds-Continued

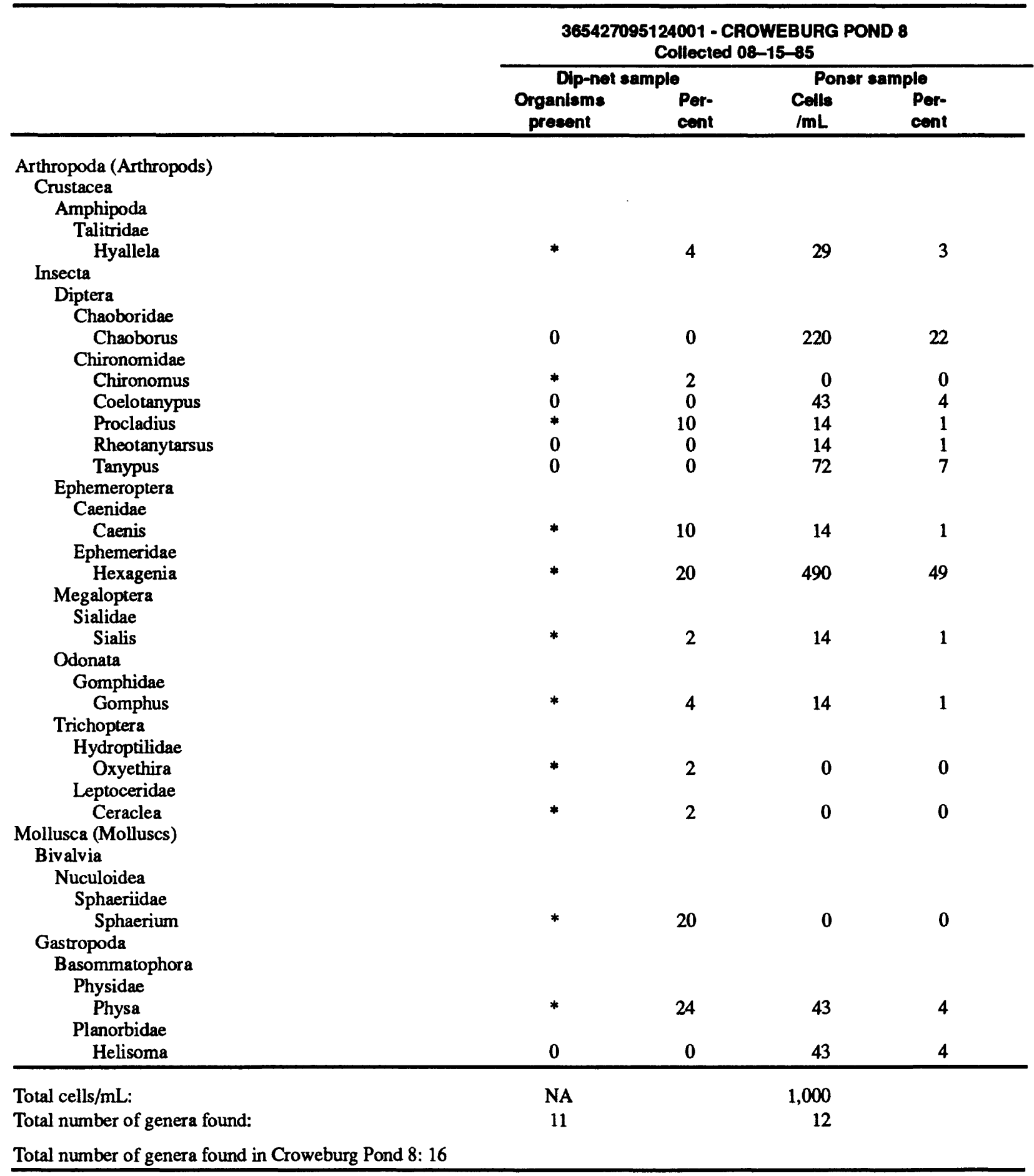


Table 19. Table 19.-Taxa and concentrations of benthic invertebrates in samples from study ponds-Continued

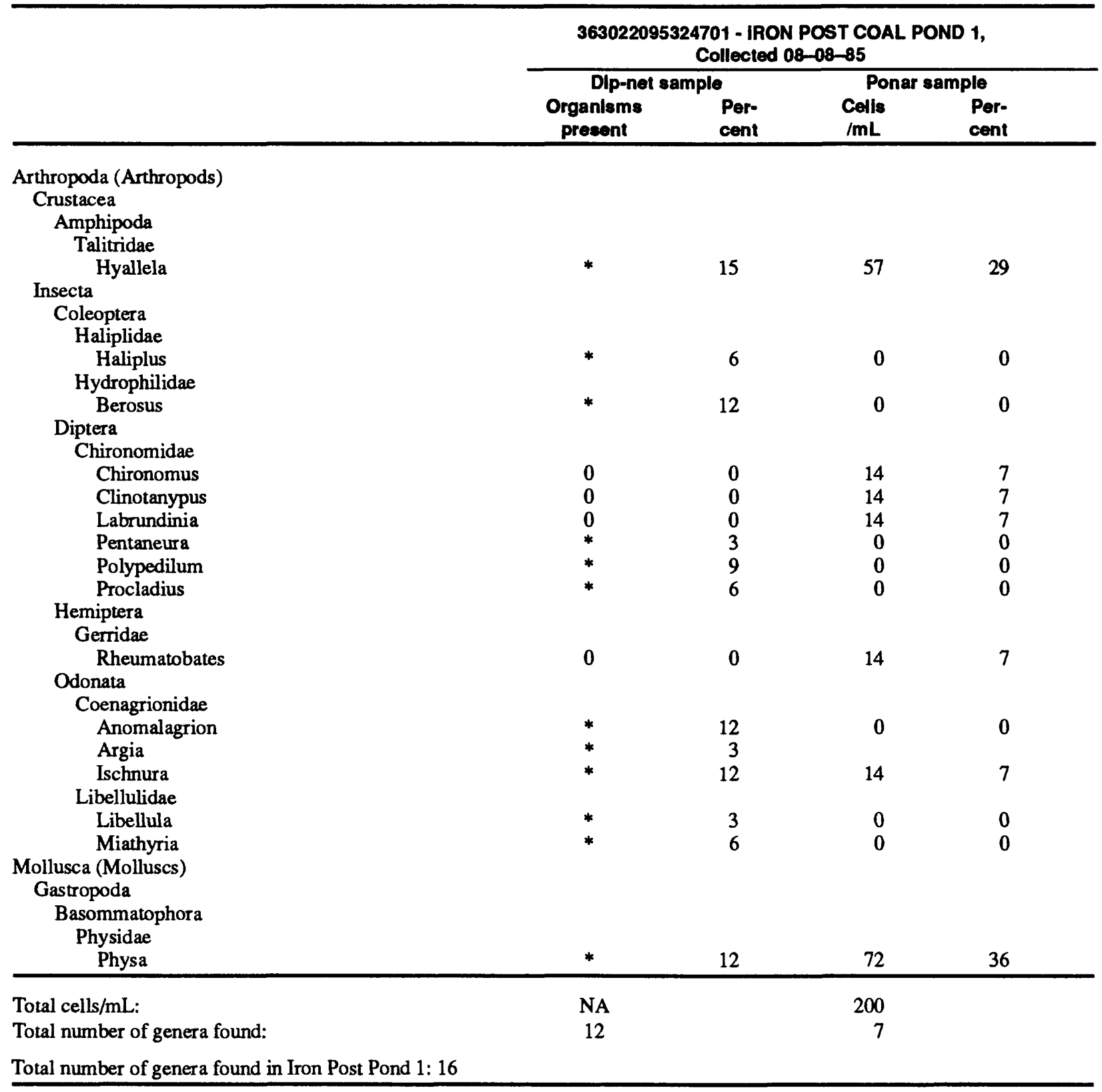


Table 19. Table 19.-Taxa and concentrations of benthic invertebrates in samples from study ponds-Continued

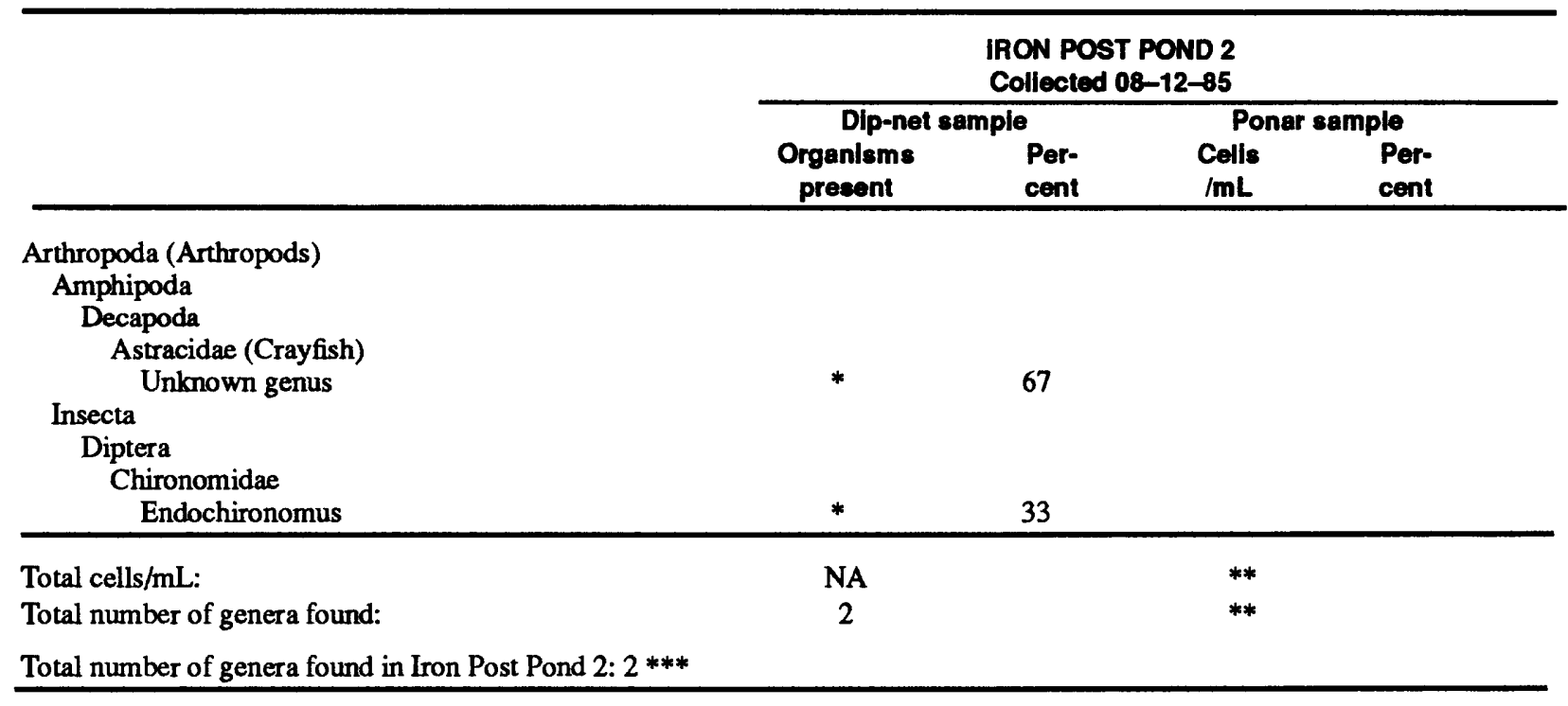


Table 19. Table 19.-Taxa and concentrations of benthic invertebrates in samples from study ponds-Continued

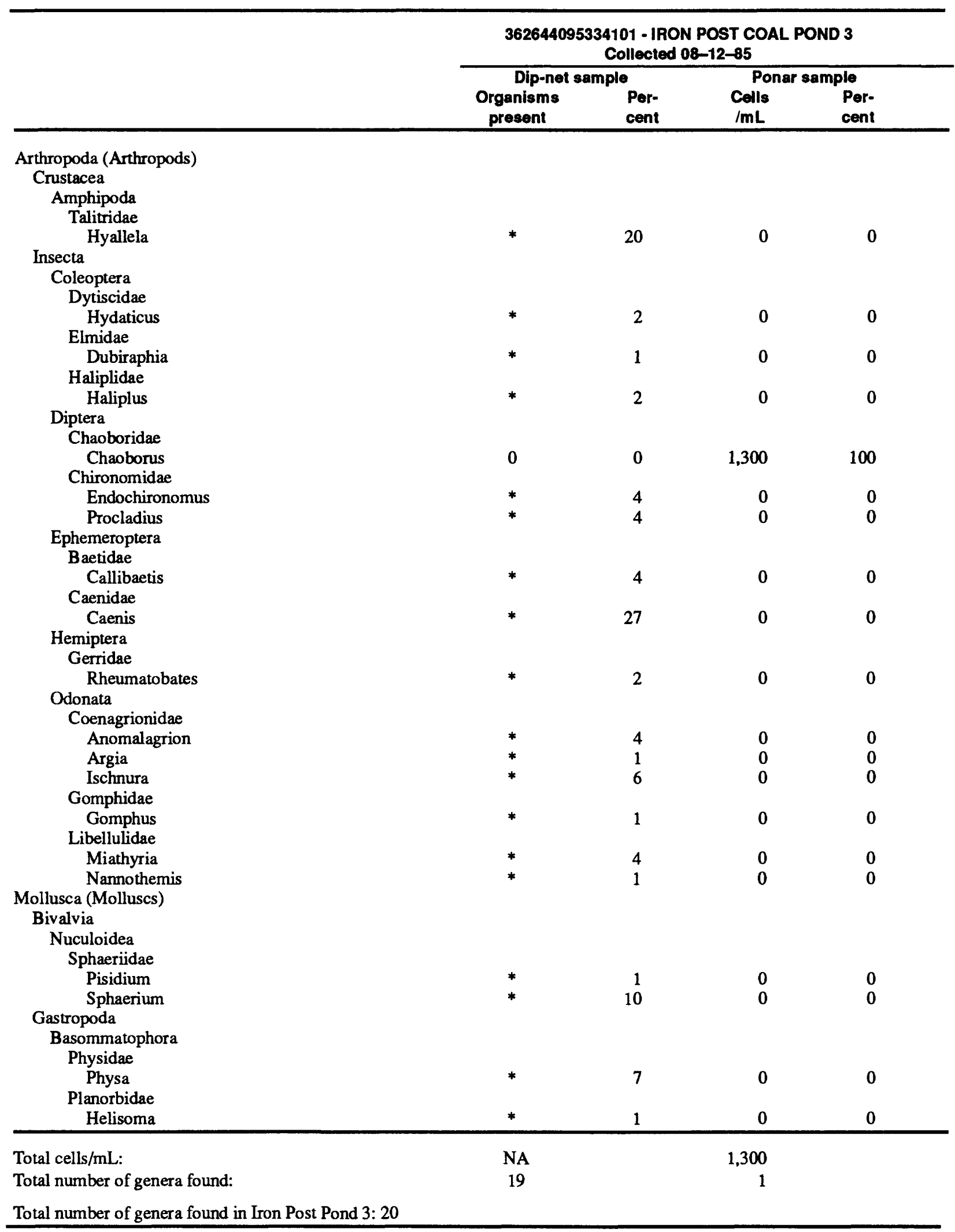


Table 19. Table 19.-Taxa and concentrations of benthic invertebrates in samples from study ponds-Continued

\begin{tabular}{|c|c|c|c|c|}
\hline & \multicolumn{4}{|c|}{$\begin{array}{c}362632095350201 \text { - IRON POST COAL POND } 4 \\
\text { Collected 08-06-85 } \\
\end{array}$} \\
\hline & $\begin{array}{c}\text { Dip-net } \\
\text { Organiems } \\
\text { present }\end{array}$ & $\begin{array}{l}\text { Per- } \\
\text { cent }\end{array}$ & $\begin{array}{l}\text { Por } \\
\text { Colls } \\
/ \mathrm{mL}\end{array}$ & $\begin{array}{l}\text { ple } \\
\text { Per- } \\
\text { cent }\end{array}$ \\
\hline \multicolumn{5}{|l|}{ Annelida (Segmented Worms) } \\
\hline \multicolumn{5}{|l|}{ Oligochaeta } \\
\hline \multicolumn{5}{|l|}{ Plesiopora } \\
\hline \multicolumn{5}{|l|}{ Tubificidae } \\
\hline Branchiura & 0 & 0 & 29 & 2 \\
\hline \multicolumn{5}{|l|}{ Arthropoda (Arthropods) } \\
\hline \multicolumn{5}{|l|}{ Crustacea } \\
\hline \multicolumn{5}{|l|}{ Amphipoda } \\
\hline \multicolumn{5}{|l|}{ Gammaridae } \\
\hline Gammarus & $*$ & 1 & 0 & 0 \\
\hline \multicolumn{5}{|l|}{ Insecta } \\
\hline \multicolumn{5}{|l|}{ Coleoptera } \\
\hline \multicolumn{5}{|l|}{ Elmidae } \\
\hline Dubiraphia & * & 2 & 0 & 0 \\
\hline \multicolumn{5}{|l|}{ Diptera } \\
\hline \multicolumn{5}{|c|}{ Ceratopogonidae $=$ heleidae } \\
\hline Bezzia & * & 17 & 0 & 0 \\
\hline \multirow{2}{*}{\multicolumn{5}{|c|}{ Chaoboridae }} \\
\hline & & & & \\
\hline Chaoborus & 0 & 0 & 560 & 43 \\
\hline \multicolumn{5}{|l|}{ Chironomidae } \\
\hline Endochironomus & * & 5 & 0 & 0 \\
\hline Pentaneura & * & 8 & 160 & 12 \\
\hline Polypedilum & * & 4 & 14 & 1 \\
\hline Procladius & 0 & 0 & 29 & 2 \\
\hline Tanypus & * & 5 & 130 & 10 \\
\hline \multicolumn{5}{|l|}{ Culicidae } \\
\hline Anopheles & $*$ & 1 & 0 & 0 \\
\hline \multicolumn{5}{|l|}{ Ephemeroptera } \\
\hline Baetidae & & & & \\
\hline Callibaetis & * & 10 & 0 & 0 \\
\hline Caenidae & & & & \\
\hline Caenis & * & 22 & 0 & 0 \\
\hline Ephemeridae & & & & \\
\hline Hexagenia & 0 & 0 & 200 & 15 \\
\hline Hemiptera & & & & \\
\hline Corixidae & & & & \\
\hline Trichocorixa & * & 1 & 0 & 0 \\
\hline Gerridae & & & & \\
\hline Trepobates & * & 1 & 0 & 0 \\
\hline Megaloptera & & & & \\
\hline Sialidae & & & & \\
\hline Sialis & $\mathbf{0}$ & $\mathbf{0}$ & 29 & 2 \\
\hline Odonata & & & & \\
\hline Coenagrionidae & & & & \\
\hline Anomalagrion & $*$ & 3 & 0 & 0 \\
\hline Libellulidae & & & & \\
\hline Libellula & * & 2 & 0 & 0 \\
\hline Nannothemis & * & 5 & 0 & 0 \\
\hline Trichoptera & & & & \\
\hline Hydroptilidae & & & & \\
\hline Oxyethira & * & 1 & 0 & 0 \\
\hline
\end{tabular}


Table 19. Table 19.-Taxa and concentrations of benthic invertebrates in samples from study ponds-Continued

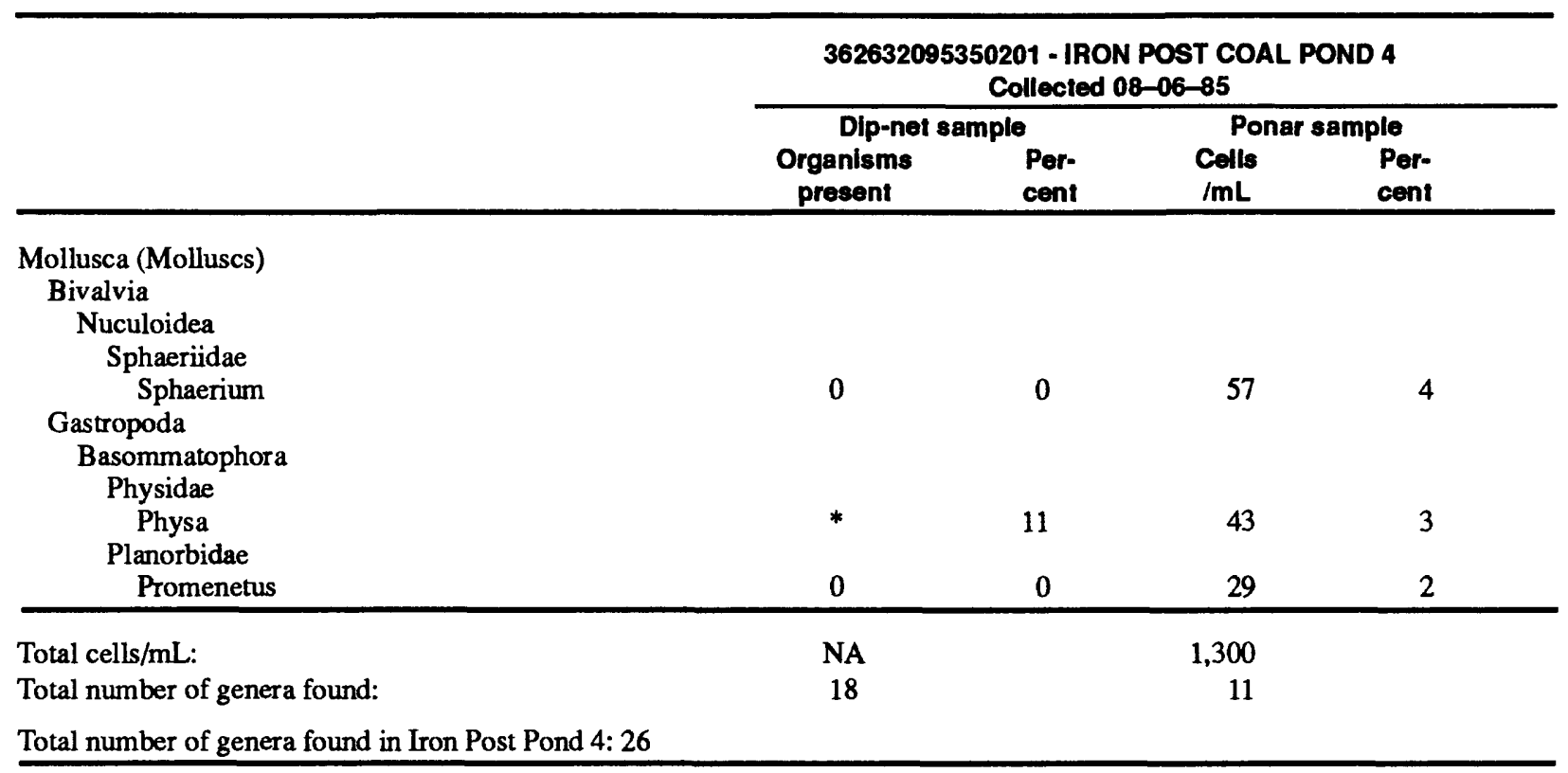


Tabie 19. Table 19.-Taxa and concentrations of benthic invertebrates in samples from study ponds-Continued

\begin{tabular}{|c|c|c|c|c|}
\hline & \multicolumn{4}{|c|}{$\begin{array}{c}362609095342301 \text { - IRON POST COAL POND } 5 \\
\text { Collected 08-06-85 }\end{array}$} \\
\hline & \multicolumn{2}{|c|}{ Dip-net sample } & \multicolumn{2}{|c|}{ Ponar sample } \\
\hline & $\begin{array}{c}\text { Organisms } \\
\text { present }\end{array}$ & $\begin{array}{l}\text { Per- } \\
\text { cent }\end{array}$ & $\begin{array}{c}\text { Ceils } \\
/ \mathrm{mL}\end{array}$ & $\begin{array}{l}\text { Per- } \\
\text { cent }\end{array}$ \\
\hline \multicolumn{5}{|l|}{ Arthropoda (Arthropods) } \\
\hline \multicolumn{5}{|l|}{ Crustacea } \\
\hline \multicolumn{5}{|l|}{ Amphipoda } \\
\hline \multicolumn{5}{|l|}{ Talitridae } \\
\hline Hyallela & * & 21 & 0 & 0 \\
\hline \multicolumn{5}{|l|}{ Insecta } \\
\hline \multicolumn{5}{|l|}{ Coleoptera } \\
\hline \multicolumn{5}{|l|}{ Dytiscidae } \\
\hline Hydrovatus & * & 13 & 0 & 0 \\
\hline \multicolumn{5}{|c|}{ Diptera } \\
\hline \multicolumn{5}{|c|}{ Ceratopogonidae $=$ Heleidae } \\
\hline Palpomyia & * & 1 & 57 & 4 \\
\hline \multicolumn{5}{|l|}{ Chaoboridae } \\
\hline Chaoborus & $\mathbf{0}$ & 0 & 460 & 33 \\
\hline \multicolumn{5}{|l|}{ Chironomidae } \\
\hline Chironomus & $*$ & 5 & 200 & 14 \\
\hline Clinotanypus & $*$ & 2 & 0 & 0 \\
\hline Pentaneura & 0 & 0 & 43 & 3 \\
\hline Phaenopsectra & 0 & 0 & 57 & 4 \\
\hline Procladius & $*$ & 6 & 0 & 0 \\
\hline Tribelos & 0 & 0 & 29 & 2 \\
\hline \multicolumn{5}{|l|}{ Culicidae } \\
\hline Aedes & $*$ & 7 & 0 & 0 \\
\hline Culex & 0 & 0 & 14 & 1 \\
\hline \multicolumn{5}{|l|}{ Tabanidae } \\
\hline Chrysops & $*$ & 2 & 0 & 0 \\
\hline Tabanus & $*$ & 1 & 0 & 0 \\
\hline \multicolumn{5}{|l|}{ Ephemeroptera } \\
\hline \multicolumn{5}{|l|}{ Baetidae } \\
\hline Callibaetis & $*$ & 5 & 14 & 1 \\
\hline Caenidae & & & & \\
\hline Caenis & $*$ & 2 & 0 & 0 \\
\hline Hemiptera & & & & \\
\hline Veliidae & & & & \\
\hline Microvelia & $\mathbf{0}$ & 0 & 29 & 2 \\
\hline Odonata & & & & \\
\hline Coenagrionidae & & & & \\
\hline Anomalagrion & * & 7 & 43 & 3 \\
\hline Argia & $*$ & 1 & & \\
\hline Enallagma & $*$ & 1 & & \\
\hline Ischnura & * & 7 & 14 & 1 \\
\hline Gomphidae & & & & \\
\hline Gomphus & $*$ & 1 & 0 & 0 \\
\hline Libellulidae & & & & \\
\hline Erythemis & $*$ & 2 & 86 & 6 \\
\hline Libellula & $*$ & 3 & 0 & 0 \\
\hline Miathyria & $*$ & 1 & 0 & 0 \\
\hline Nannothemis & $*$ & 6 & 0 & 0 \\
\hline Tramea & $*$ & 1 & 0 & 0 \\
\hline Mollusca (Molluscs) & & & & \\
\hline Bivalvia & & & & \\
\hline Nuculoidea & & & & \\
\hline Sphaeriidae & & & & \\
\hline Pisidium & * & 1 & 0 & 0 \\
\hline
\end{tabular}


Table 19. Table 19.-Taxa and concentrations of benthic invertebrates in samples from study ponds-Continued

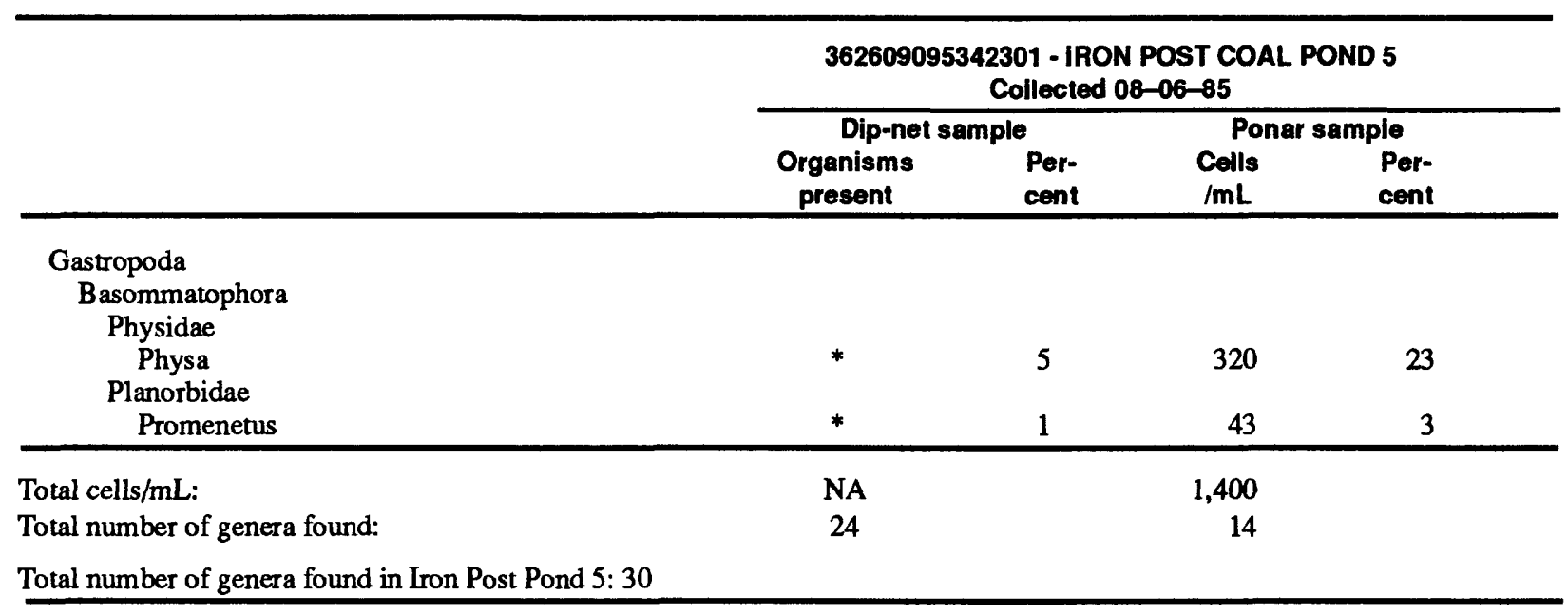


Table 19. Table 19.-Taxa and concentrations of benthic invertebrates in samples from study ponds-Continued

\begin{tabular}{|c|c|c|c|c|}
\hline & \multicolumn{4}{|c|}{$\begin{array}{l}\text { 364051095274001 - IRON POST COAL POND } 6 \\
\text { Collected 08-28-85 }\end{array}$} \\
\hline & $\begin{array}{c}\text { Dip-net } \\
\text { Organiams } \\
\text { present }\end{array}$ & $\begin{array}{l}\text { Per- } \\
\text { cent }\end{array}$ & $\begin{array}{l}\text { Pon } \\
\text { Colls } \\
/ \mathrm{mL}\end{array}$ & $\begin{array}{l}\text { Ple } \\
\text { Per- } \\
\text { cent }\end{array}$ \\
\hline \multirow{2}{*}{\multicolumn{5}{|c|}{$\begin{array}{l}\text { Arthropoda (Arthropods) } \\
\text { Insecta }\end{array}$}} \\
\hline & & & & \\
\hline \multicolumn{5}{|l|}{$\begin{array}{l}\text { Insecta } \\
\text { Coleoptera }\end{array}$} \\
\hline \multicolumn{5}{|l|}{ Dytiscidae } \\
\hline Coptotomus & * & 1 & $\mathbf{0}$ & $\mathbf{0}$ \\
\hline \multicolumn{5}{|l|}{ Diptera } \\
\hline \multicolumn{5}{|l|}{ Chironomidae } \\
\hline Chironomus & * & 25 & 0 & 0 \\
\hline Rheotanytarsus & $\mathbf{0}$ & $\mathbf{0}$ & 14 & 6 \\
\hline Tanypus & * & 16 & 14 & 6 \\
\hline Xenochironomus & * & 12 & 0 & $\mathbf{0}$ \\
\hline \multicolumn{5}{|l|}{ Ephemeroptera } \\
\hline \multicolumn{5}{|l|}{ Caenidae } \\
\hline Caenis & * & 1 & $\mathbf{0}$ & $\mathbf{0}$ \\
\hline \multicolumn{5}{|l|}{ Odonata } \\
\hline \multicolumn{5}{|l|}{ Coenagrionidae } \\
\hline Ischnura & * & 3 & $\mathbf{0}$ & 0 \\
\hline \multicolumn{5}{|l|}{ Corduliidae } \\
\hline Epitheca & * & 3 & $\mathbf{0}$ & $\mathbf{0}$ \\
\hline \multicolumn{5}{|l|}{ Libellulidae } \\
\hline Erythemis & * & 3 & $\mathbf{0}$ & 0 \\
\hline \multicolumn{5}{|l|}{ Mollusca (Molluscs) } \\
\hline Gastropoda & & & & \\
\hline \multicolumn{5}{|l|}{ Basommatophora } \\
\hline \multicolumn{5}{|l|}{ Physidae } \\
\hline Physa & $*$ & 38 & 200 & 87 \\
\hline Total cells/mL: & NA & & 230 & \\
\hline Total number of genera found: & 9 & & 3 & \\
\hline Total number of genera found in & & & & \\
\hline
\end{tabular}


Table 19. Table 19.-Taxa and concentrations of benthic invertebrates in samples from study ponds-Continued

\begin{tabular}{|c|c|c|c|c|}
\hline & \multicolumn{4}{|c|}{$\begin{array}{c}\text { 362605095342001 - IRON POST COAL POND 7, } \\
\text { SITE 4 } \\
\text { Collected 08-20-85 }\end{array}$} \\
\hline & $\begin{array}{c}\text { Dip-net } \\
\text { Organisms } \\
\text { present }\end{array}$ & $\begin{array}{l}\text { Per- } \\
\text { cent }\end{array}$ & $\begin{array}{l}\text { Pon } \\
\text { Colls } \\
/ \mathrm{mL}\end{array}$ & $\begin{array}{l}\text { Ple } \\
\text { Per- } \\
\text { cent }\end{array}$ \\
\hline $\begin{array}{l}\text { Arthropoda (Arthropods) } \\
\text { Insecta } \\
\text { Diptera } \\
\text { Chironomidae } \\
\text { Pseudochironomus } \\
\text { Stictochironomus } \\
\text { Ephemeroptera } \\
\text { Baetidae } \\
\text { Callibaetis } \\
\text { Caenidae } \\
\text { Caenis } \\
\text { Odonata } \\
\text { Coenagrionidae } \\
\text { Ischnura } \\
\text { Corduliidae } \\
\text { Epitheca } \\
\text { Neurocordulia } \\
\text { Libellulidae } \\
\text { Libellula } \\
\text { Nannothemis } \\
\text { Mollusca (Molluscs) } \\
\text { Gastropoda } \\
\text { Basommatophora } \\
\text { Physidae } \\
\text { Physa }\end{array}$ & $\begin{array}{l}* \\
* \\
* \\
* \\
*\end{array}$ & $\begin{array}{r}2 \\
1 \\
\\
1 \\
87\end{array}$ & & \\
\hline $\begin{array}{l}\text { Total cells/mL: } \\
\text { Total number of genera found: } \\
\text { Total number of genera found in Iron Post Pond } 7: 10^{* * *}\end{array}$ & $\begin{array}{c}\text { NA } \\
10\end{array}$ & & $\begin{array}{l}* * \\
* *\end{array}$ & \\
\hline
\end{tabular}


Table 19. Table 19. - Taxa and concentrations of benthic invertebrates in samples from study ponds-Continued

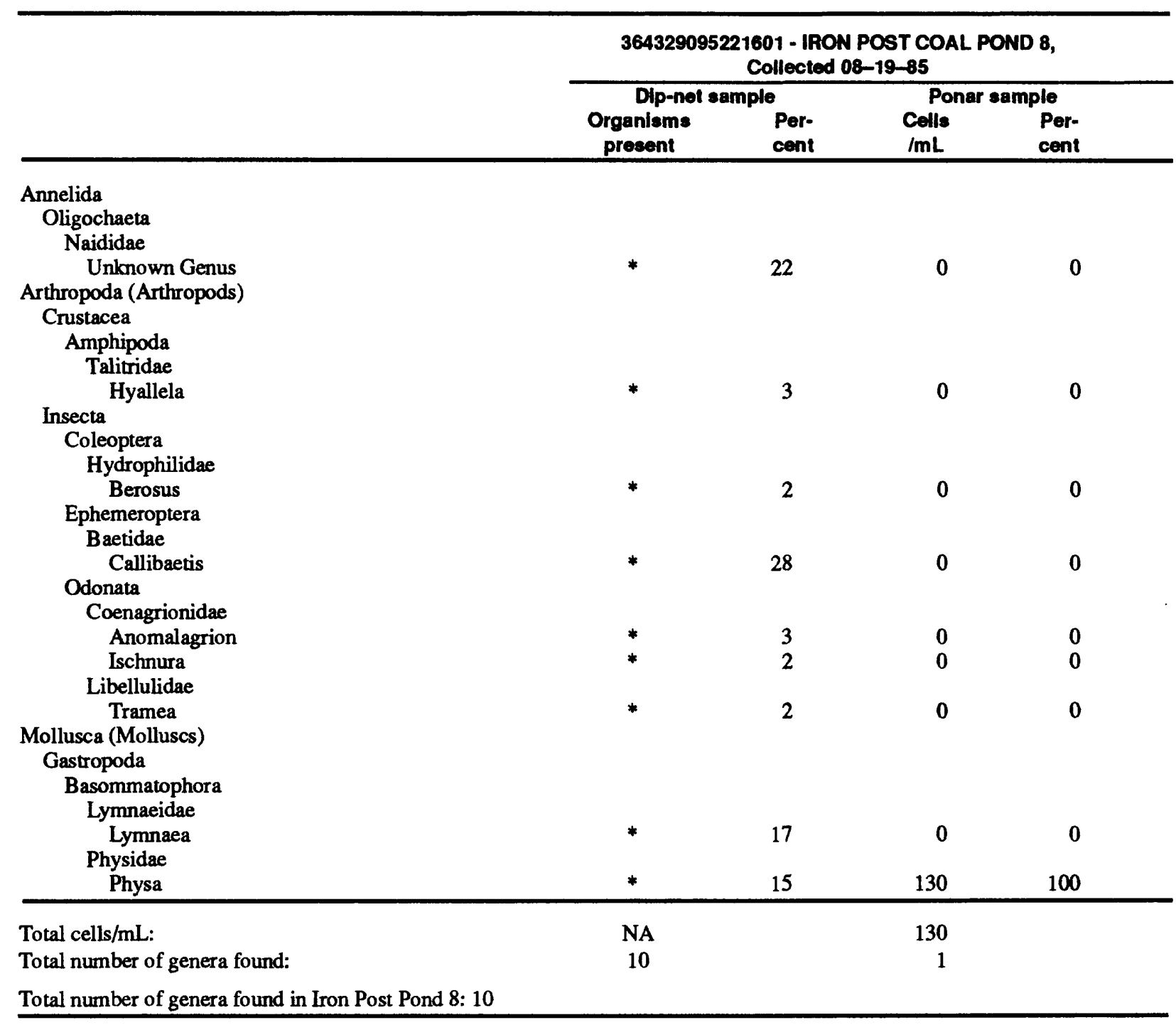


Table 19. Table 19.-Taxa and concentrations of benthic invertebrates in samples from study ponds-Continued

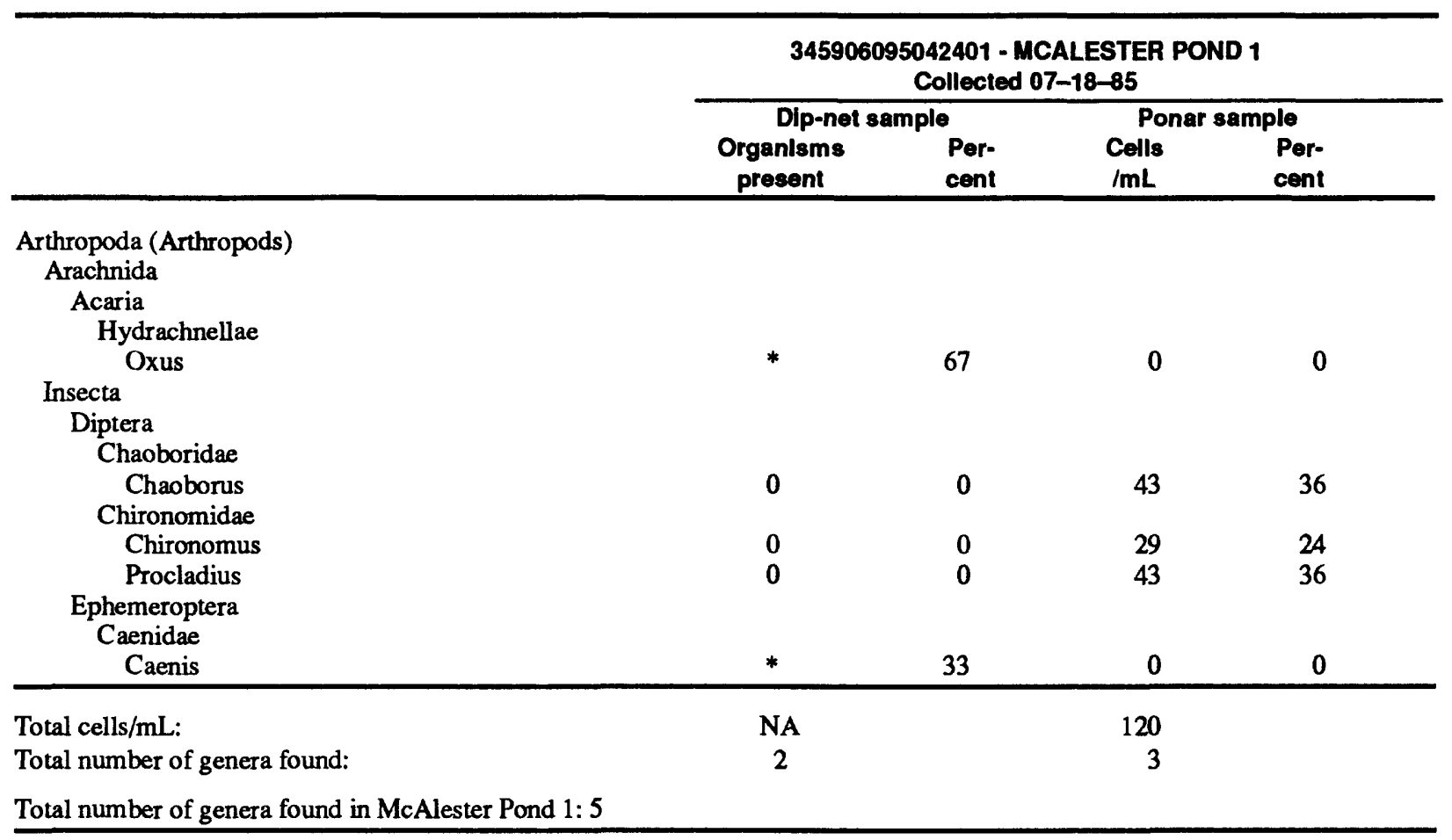


Table 19. Table 19.-Taxa and concentrations of benthic invertebrates in samples from study ponds-Continued

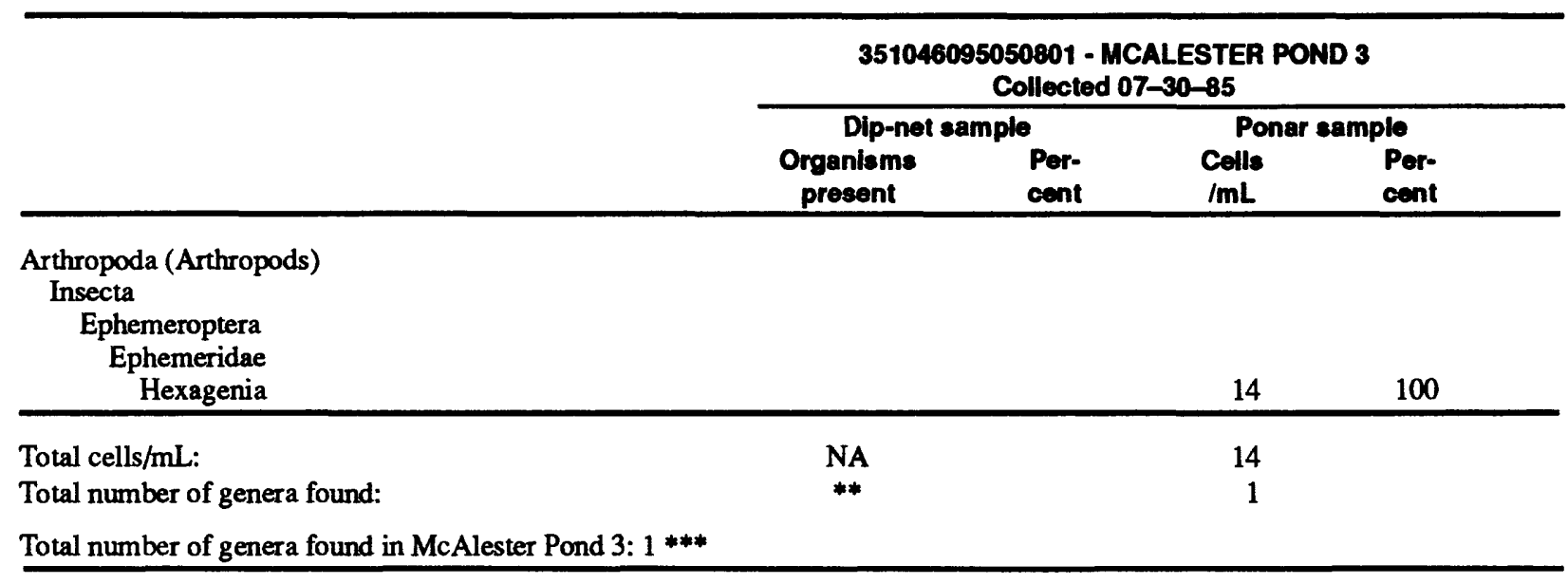


Table 19. Table 19.-Taxa and concentrations of benthic invertebrates in samples from study ponds-Continued

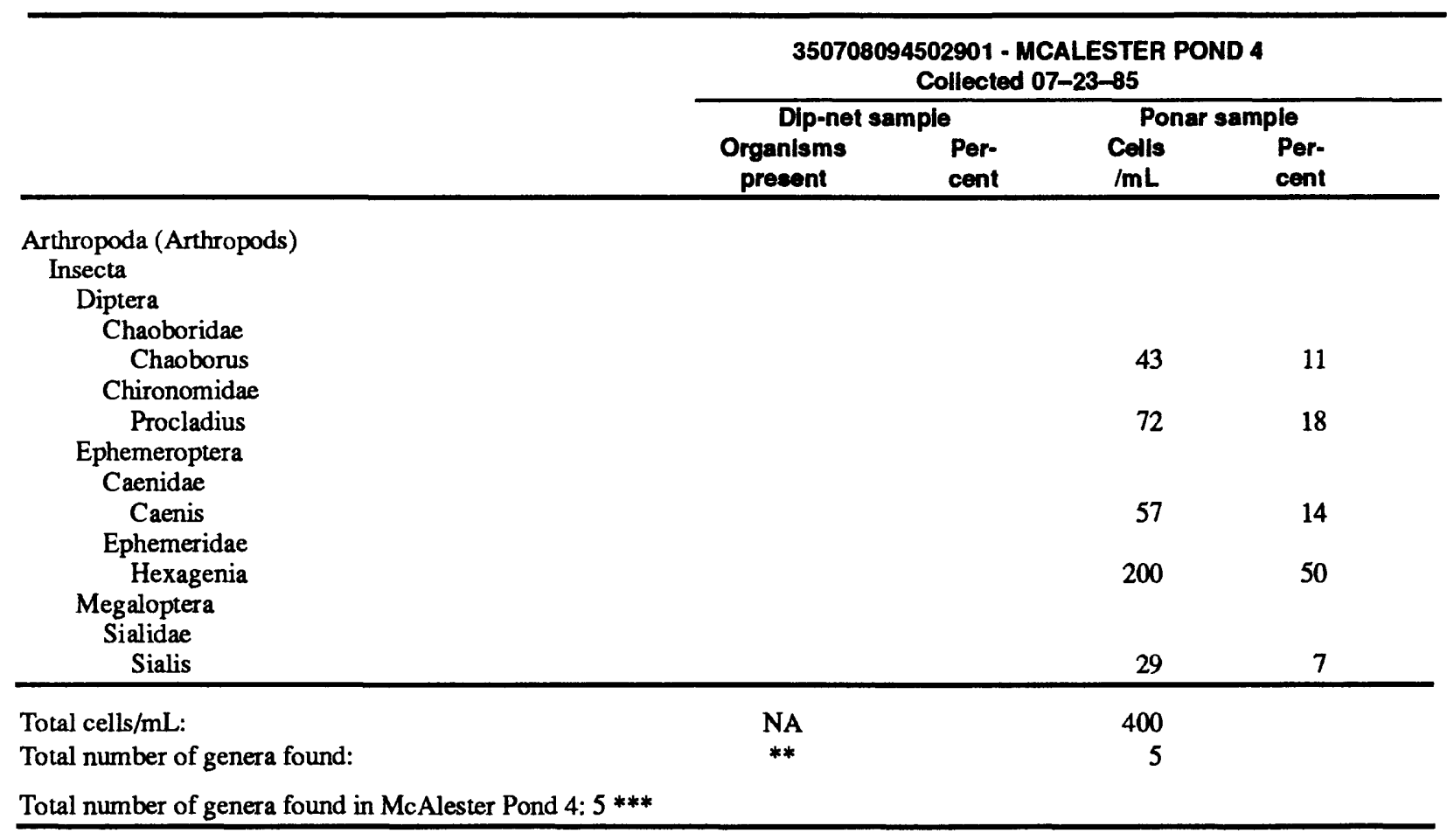


Table 19. Table 19.-Taxa and concentrations of benthic invertebrates in samples from study ponds-Continued

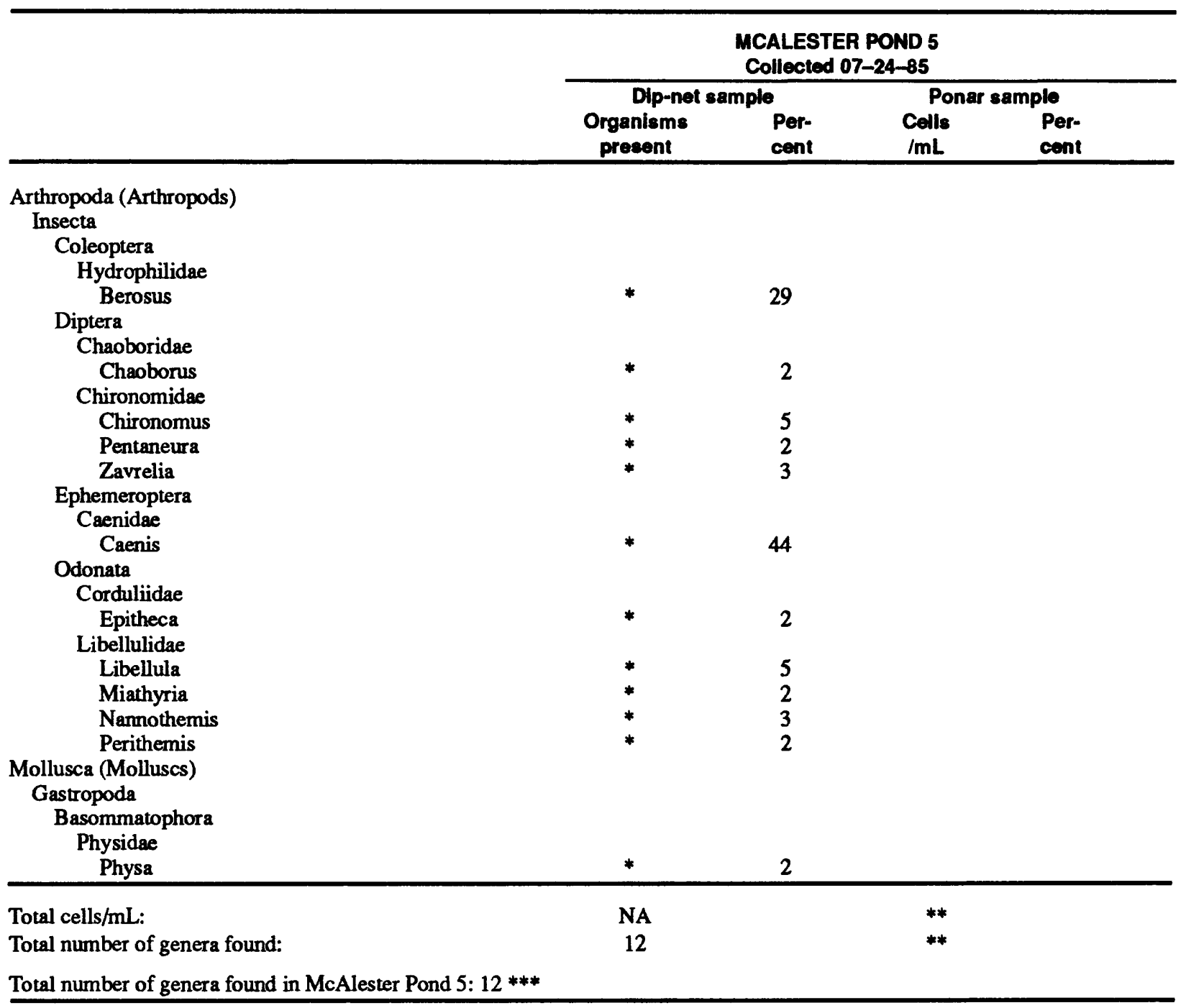


Table 19. Table 19.-Taxa and concentrations of benthic invertebrates in samples from study ponds-Continued

\begin{tabular}{|c|c|c|c|c|}
\hline & \multicolumn{4}{|c|}{$\begin{array}{c}\text { 352001094583501 - MCALESTER POND } 7 \\
\text { Collected 07-31-85 }\end{array}$} \\
\hline & \multicolumn{2}{|c|}{ Dip-net sample } & \multicolumn{2}{|c|}{ Ponar sample } \\
\hline & $\begin{array}{c}\text { Organisms } \\
\text { present }\end{array}$ & $\begin{array}{l}\text { Per- } \\
\text { cent }\end{array}$ & $\begin{array}{l}\text { Cells } \\
/ \mathrm{mL}\end{array}$ & $\begin{array}{l}\text { Per- } \\
\text { cent }\end{array}$ \\
\hline \multicolumn{5}{|l|}{ Arthropoda (Arthropods) } \\
\hline \multicolumn{5}{|l|}{ Insecta } \\
\hline \multirow{2}{*}{\multicolumn{5}{|c|}{ Coleoptera }} \\
\hline \multicolumn{2}{|l|}{ Dytiscidae } & & & \\
\hline Hygrotus & 0 & $\mathbf{0}$ & 150 & 3 \\
\hline \multicolumn{5}{|l|}{ Haliplidae } \\
\hline Brychius & * & 2 & 0 & 0 \\
\hline Glyptotendipes & * & 1 & 22 & $<1$ \\
\hline Peltodytes & * & 6 & 0 & $\mathbf{0}$ \\
\hline \multicolumn{5}{|l|}{ Hydrophilidae } \\
\hline Berosus & * & 7 & 86 & 2 \\
\hline \multicolumn{5}{|l|}{ Diptera } \\
\hline \multicolumn{5}{|l|}{ Chaoboridae } \\
\hline Chaoborus & 0 & 0 & 3,100 & 73 \\
\hline \multicolumn{5}{|l|}{ Chironomidae } \\
\hline Coelotanypus & * & 1 & 0 & 0 \\
\hline Glyptotendipes & 0 & 0 & 22 & $<1$ \\
\hline Microtendipes & * & 1 & 0 & 0 \\
\hline Procladius & 0 & 0 & 65 & 2 \\
\hline \multicolumn{5}{|l|}{ Culicidae } \\
\hline Culex & * & $<1$ & 0 & 0 \\
\hline \multirow{2}{*}{\multicolumn{5}{|c|}{ Ephemeroptera }} \\
\hline \multicolumn{2}{|l|}{ Baetidae } & & & \\
\hline Callibaetis & * & 8 & 370 & 9 \\
\hline \multicolumn{5}{|l|}{ Caenidae } \\
\hline Caenis & * & 8 & 86 & 2 \\
\hline \multicolumn{5}{|l|}{ Ephemeridae } \\
\hline Hexagenia & * & $<1$ & 0 & 0 \\
\hline \multicolumn{5}{|l|}{ Hemiptera } \\
\hline \multicolumn{5}{|l|}{ Corixidae } \\
\hline Sigara & 0 & 0 & 65 & 2 \\
\hline Trichocorixa & * & 1 & 0 & 0 \\
\hline Female or immature & * & 2 & 43 & 1 \\
\hline Megaloptera & & & & \\
\hline Sialidae & & & & \\
\hline Sialis & * & 1 & 22 & $<1$ \\
\hline Odonata & & & & \\
\hline Gomphidae & & & & \\
\hline Gomphus & * & 6 & 22 & $<1$ \\
\hline Libellulidae & & & & \\
\hline Erythemis & * & 1 & 0 & 0 \\
\hline Neurocordulia & * & 3 & 130 & 3 \\
\hline $\begin{array}{l}\text { Plathemis } \\
\text { Plo }\end{array}$ & * & 1 & 0 & 0 \\
\hline Somatochlora & * & 1 & 43 & 1 \\
\hline Mollusca (Molluscs) & & & & \\
\hline Gastropoda & & & & \\
\hline Basommatophora & & & & \\
\hline Physidae & & & & \\
\hline Physa & * & 50 & 22 & $<1$ \\
\hline Total cells/mL: & NA & & 4,300 & \\
\hline Total number of genera found: & 19 & & 16 & \\
\hline Total number of genera found in & & & & \\
\hline
\end{tabular}


Table 19. Table 19.-Taxa and concentrations of benthic invertebrates in samples from study ponds-Continued

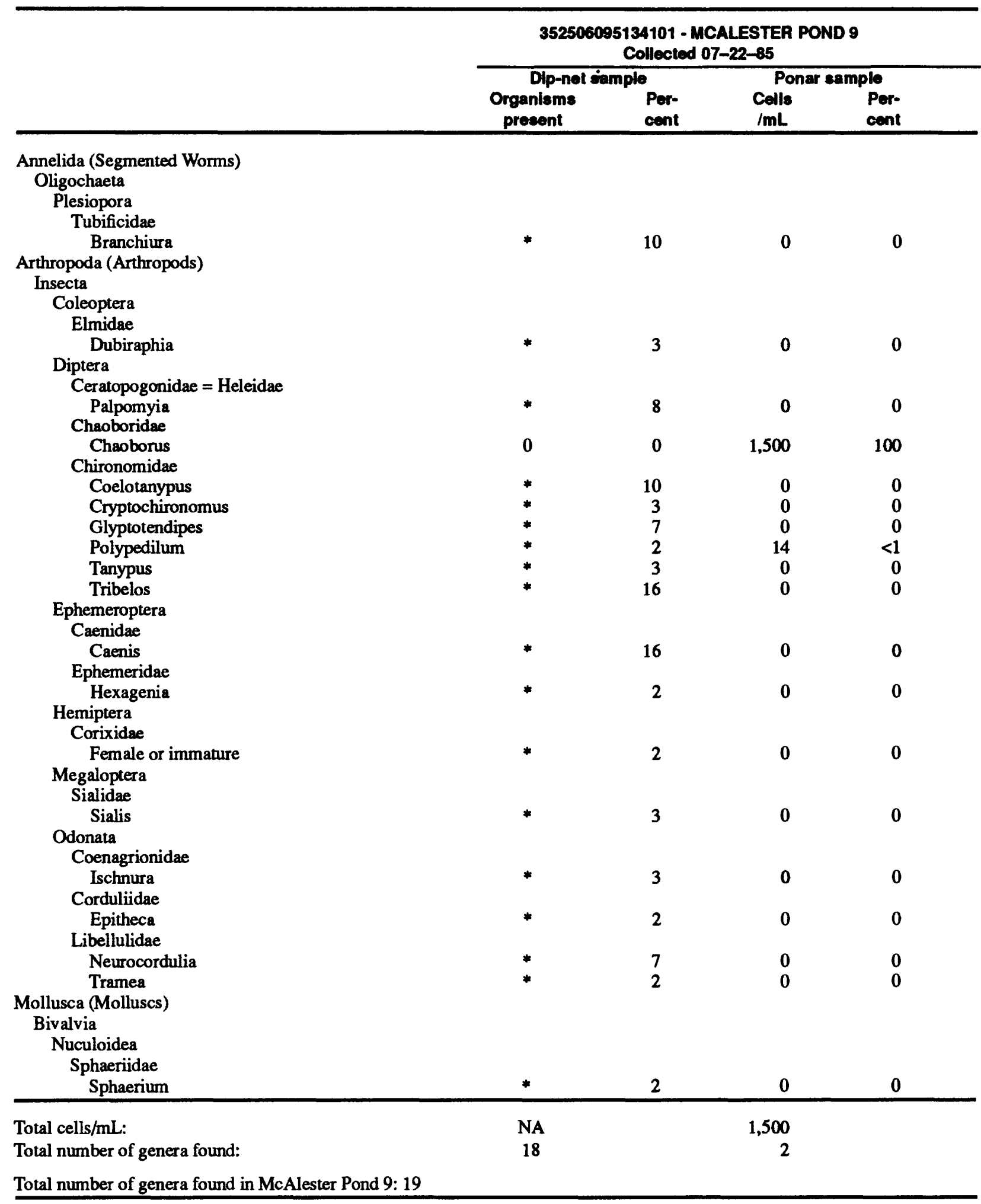

